\title{
Educação permanente em saúde para os trabalhadores do SUS
}

\author{
Fernanda de Oliveira Sarreta
}

SARRETA, FO. Educação permanente em saúde para os trabalhadores do SUS [online]. São Paulo: Editora UNESP; São Paulo: Cultura Acadêmica, 2009. 248 p. ISBN 978-85-7983-009-9. Available from SciELO Books <http://books.scielo.org>.

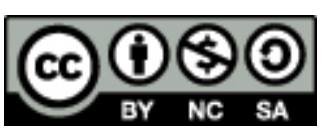

All the contents of this chapter, except where otherwise noted, is licensed under a Creative Commons Attribution-Non Commercial-ShareAlike 3.0 Unported.

Todo o conteúdo deste capítulo, exceto quando houver ressalva, é publicado sob a licença Creative Commons Atribuição Uso Não Comercial - Partilha nos Mesmos Termos 3.0 Não adaptada.

Todo el contenido de este capítulo, excepto donde se indique lo contrario, está bajo licencia de la licencia Creative Commons Reconocimento-NoComercial-CompartirIgual 3.0 Unported. 


\section{GDUCAÇÃO PERMANENTE EM SAUDE PARA OS TRABALHADORES DO sUS}

FERNANDA DE OLIVEIRA SARRETA 


\section{EDUCAÇÃO PERMANENTE EM SAÚDE PARA OS TRABALHADORES DO SUS}





\section{FERNANDA DE OLIVEIRA SARRETA}

\section{EDUCAÇÃO \\ PERMANENTE EM SAÚDE PARA OS TRABALHADORES DO SUS}

CULTURA

$\frac{\text { ACADÊMICA }}{\text { Editon } a}$ 


\section{(C) 2009 Editora UNESP}

Direitos de publicação reservados à:

Fundação Editora da UNESP (FEU)

Praça da Sé, 108

01001-900 - São Paulo - SP

Tel.: (0xx11) 3242-7171

Fax: (0xx11) 3242-7172

www.editoraunesp.com.br

feu@editora.unesp.br

CIP - Brasil. Catalogação na fonte

Sindicato Nacional dos Editores de Livros, RJ

S258e

Sarreta, Fernanda de Oliveira

Educação permanente em saúde para os trabalhadores do SUS / Fernanda de Oliveira Sarreta. - São Paulo : Cultura Acadêmica, 2009.

Inclui bibliografia

ISBN 978-85-7983-009-9

1. Pessoal da área médica - Treinamento - Brasil. 2. Educação permanente - Brasil. 3. Sistema Único de Saúde (Brasil). 4. Política de saúde - Brasil. 5. Política de educação médica - Brasil. I. Título.

09-6055.

CDD: 610.70981

CDU: $614.25(81)$

Este livro é publicado pelo Programa de Publicações Digitais da Pró-Reitoria de Pós-Graduação da Universidade Estadual Paulista "Júlio de Mesquita Filho" (UNESP)

Editora afiliada:

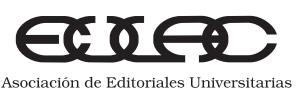

Asociación de Editoriales Universitarias de América Latina y el Caribe

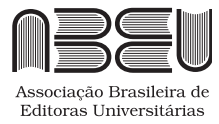


Dedico,

aos meus pais, Oneida e Gilberto, que nas atitudes mais simples me ensinaram o verdadeiro valor da vida, das pessoas e do trabalho. Principalmente, me ensinaram a construir e reconstruir.

Com amor, Fernanda. 



\section{AgradeCIMENTOS}

Agradeço a minha querida professora Iris, pela confiança e carinho em nossa convivência, que com sua sabedoria me ensinou a vencer desafios e a construir sonhos.

Agradeço a minha família, pelo amor que compartilho, onde encontro aconchego e aprendo o valor da união diante das nossas conquistas e perdas.

Agradeço a todas as pessoas que participam da minha vida e de um modo ou de outro contribuíram para a realização deste estudo. Foram essas relações, em que vivenciei afetos e atitudes, que me mostraram a importância das nossas ações para cuidar da saúde e da doença, de maneira humanizada, carinhos...

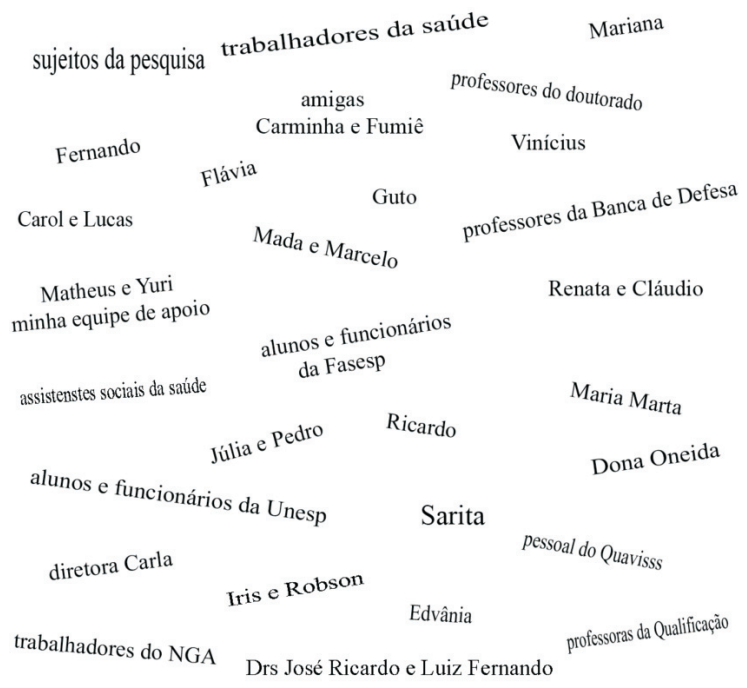


O Marceneiro e as Ferramentas

Contam que, em uma marcenaria, houve uma estranha assembleia.

Foi uma reunião onde as ferramentas juntaram-se para acertar suas diferenças.

Um martelo estava exercendo a presidência, mas os participantes

exigiram que ele renunciasse.

A causa? Fazia demasiado barulho e passava todo o tempo golpeando.

O martelo aceitou sua culpa, mas pediu que também fosse expulso o parafuso, alegando que ele dava muitas voltas para conseguir algo.

Diante do ataque, o parafuso concordou, mas por sua vez pediu a expulsão da lixa. Disse que ela era muito áspera no tratamento com os demais, entrando sempre em atritos.

A lixa acatou, com a condição de que se expulsasse o metro, que sempre media os outros segundo a sua medida, como se fosse o único perfeito.

Nesse momento, entrou o marceneiro, juntou tudo e iniciou seu trabalho. Utilizou o martelo, a lixa, o metro, o parafuso. E a rústica madeira se converteu em belos móveis.

Quando o marceneiro foi embora, as ferramentas voltaram à discussão.

Mas o serrote adiantou-se e disse:

- Senhores, ficou demonstrado que temos defeitos, mas o marceneiro trabalha com nossas qualidades, ressaltando nossos pontos valiosos. Portanto, em vez de pensar em nossas fraquezas, devemos nos concentrar em nossos pontos fortes.

Então, a assembleia entendeu que o martelo era forte, o parafuso unia e dava força, a lixa era especial para limpar e afinar asperezas e o metro era preciso e exato.

Sentiram-se como uma equipe, capaz de produzir com qualidade; e uma grande alegria tomou conta de todos pela oportunidade de trabalharem juntos.

O mesmo ocorre com os seres humanos. Quando uma pessoa busca defeitos em outra, a situação torna-se tensa e negativa.

Ao contrário, quando se busca com sinceridade o ponto forte dos outros, florescem as melhores conquistas humanas.

É fácil encontrar defeitos... Qualquer um pode fazê-lo.

Mas encontrar qualidades? Isto é para os sábios!!! 


\section{LISTA DE SIGLAS}

Abrasco

ABEPSS

AIS

CAP

Cebes

CFESS

CNRH

Conasems

Conass

Conasp

CNS

CNGTES

CRST

Deges

Degerts

DIR

DRS

EAD

ENSP

EPS
Associação de Pós-Graduação em Saúde Coletiva

Associação Brasileira de Ensino e Pesquisa em Saúde

Ações Integradas de Saúde

Caixas de Aposentadorias e Pensões

Centro Brasileiro de Estudos de Saúde

Conselho Federal de Serviço Social

Conferência Nacional de Recursos Humanos

Conselho Nacional de Secretários do Estado de São Paulo Conselho Nacional de Secretários Municipais do Estado de São Paulo

Conselho Nacional de Administração da Saúde Previdenciária

Conferência Nacional de Saúde

Conferência Nacional de Gestão do Trabalho e da Educação na Saúde

Centro de Referência em Saúde do Trabalho

Departamento de Gestão e da Educação na Saúde

Departamento de Gestão e da Regulação do Trabalho em

Saúde

Direção Regional de Saúde

Departamento Regional de Saúde

Educação a Distância

Escola Nacional de Saúde Pública

Educação Permanente em Saúde 
Fapesp

Fundação de Amparo à Pesquisa do Estado de São Paulo

FNEPAS

Fórum Nacional de Ensino das Profissões da Saúde

IAP

Instituto de Aposentadorias e Pensões

IBGE

Instituto Brasileiro de Geografia e Estatística

Inamps

Instituto Nacional de Assistência Médica e Previdência

Social

INPS

Instituto Nacional de Previdência Social

INSS

Instituto Nacional de Seguro Social

LOPS

Lei Orgânica da Previdência Social

LOS

Lei Orgânica da Saúde

$\mathrm{NOB} / \mathrm{RH}$

Norma Operacional Básica de Recursos Humanos

$\mathrm{ONG}$

Organização Não Governamental

OMS

Organização Mundial da Saúde

Opas

Organização Pan-Americana da Saúde

OS

Organização Social

$\mathrm{SF}$

Saúde da Família

SGTES

Secretaria de Gestão do Trabalho e da Educação na Saúde

Simpas

Sistema Nacional de Previdência e Assistência Social

Suds

Sistema Unificado e Descentralizado em Saúde

SUS

Sistema Único de Saúde

UAC

Unidade de Avaliação e Controle

UNE

União Nacional dos Estudantes

Unesp

Universidade Estadual Paulista 


\section{SUMÁRIO}

Introdução 13

1 A construção da pesquisa 31

2 As ideias dos trabalhadores a respeito do SUS 69

3 As Políticas Públicas de Saúde 131

4 Perspectivas da Educação Permanente em Saúde 169

Considerações finais 223

Referências bibliográficas 235

Anexos 247 
12 FERNANDA DE OLIVEIRA SARRETA 


\section{INTRODUÇÃO}

O interesse pelo tema da pesquisa, o Sistema Único de Saúde (SUS) e a formação de seus trabalhadores, nasceu de inquietações e necessidades vivenciadas durante a vida profissional - na prática, na docência e na pesquisa, fruto das relações de trabalho e das experiências construídas na área da saúde pública. A atividade profissional da pesquisadora, desenvolvida nas unidades de saúde do município de Franca/SP, leva a testemunhar na prática diária que, o saber fazer não corresponde ao saber saber, ou seja, com o conhecimento acumulado pela área da saúde. Este estado de coisas torna-se ainda mais lamentável quando "[...] se busca um outro tipo de avanço do saber, o saber ser, que se expressa por atitudes de solidariedade, civilidade, compartilhamento, responsabilidade e ética" (Brasil, 2003c, p.84).

São essas preocupações vivenciadas no cotidiano de trabalho, tanto quanto os conflitos e outros problemas que aí emergem, que exigem análises, debates e propostas, motivam a busca de conhecimentos e de respostas para problemas que impedem a qualidade de vida e da saúde da população. Essa ideia subsidia o pensar e o agir profissional com rigor científico e também insere a importância da pesquisa nesse universo. A escolha deste tema, portanto, faz parte da construção pessoal e profissional da pesquisadora, aprofundada quando a Educação Permanente em Saúde (EPS) foi regulamentada como estratégia político-pedagógica para fortalecimento e implementação do SUS. É a oportunidade de se contar com a contribuição da pesquisa para ampliar o conhecimento a respeito do SUS e desvendar seus avanços, limites e contradições. 
Deste modo, realizado a partir de falas, documentos e observação, este estudo tem como objetivo conhecer, analisar e explicar experiências que potencializam a educação permanente em saúde como estratégia para a formação dos trabalhadores da saúde e consolidação do SUS na locorregião de Franca/SP.

Decidiu-se, então, analisar essa realidade enfocando um dos atores do SUS, os trabalhadores da saúde, sem desconsiderar a importância dos usuários, gestores e formadores para a compreensão do processo em pauta. O interesse imediato nos trabalhadores da saúde deve-se à necessidade sentida, durante vários anos, de buscar respostas para o que se observa no cotidiano dos serviços do SUS: uma formação fragmentada e distante do perfil profissional para o trabalho na saúde pública.

Parte-se da ideia de que a educação pode contribuir para os problemas de saúde que envolvem o acesso, a qualidade do atendimento prestado e a resolutividade, os quais comprometem o modelo de atenção proposto e sua legitimidade. Há um desencantamento, um descrédito da sociedade brasileira quanto à viabilidade dessa política pública, provocado provavelmente pelas situações apresentadas nos serviços, tais como a implementação das ações e serviços de forma heterogênea e desigual nas regiões do País, o baixo financiamento, a falta de resolutividade da rede e o enfoque no modelo curativo, a atenção centrada na doença, a qualidade do atendimento oferecido, entre outras questões que envolvem a gestão dos serviços.

Busca-se, assim, explicar como a educação pode contribuir com esses problemas e provocar transformações nessa compreensão passiva da política pública. Portanto, esta é igualmente uma questão cultural, política e de educação a ser enfrentada pela formação profissional e pensada à luz da educação em saúde, para desvendar o que existe por trás dessa atitude que desvaloriza o que é público e julga como bom o que é oferecido no mercado. Uma educação que possa desconstruir valores e preconceitos construídos, historicamente, para superar a lógica do capital e reconstruir novos conceitos e posturas, inclusive a respeito do valor pelo próprio trabalho (Mészáros, 2005).

Como caminhos possíveis, o Ministério da Saúde tem desenvolvido estratégias e métodos de articulação de ações, saberes e práticas para potencializar a atenção integral, resolutiva e humanizada. Dentre as políticas em desenvolvimento, a Política de Educação Permanente em Saúde foi arquitetada 
como estratégia para a Formação e o Desenvolvimento dos Trabalhadores do Setor. ${ }^{1}$ Essa Política que reafirma os princípios democráticos do SUS e atravessa suas diferentes ações e instâncias foi criada para implementar a atenção integral e consolidar o modelo de atenção proposto pelo SUS a partir de experiências e possibilidades concretas, com referência nas características locais e regionais, e ainda valoriza o desenvolvimento da autonomia e o protagonismo dos sujeitos envolvidos nos processos de produção da saúde.

A exploração desse tema levou a questionar se é possível modificar a ação dos trabalhadores na saúde, fazendo com que a formação profissional provoque o desenvolvimento da crítica e autocrítica e a reflexão do mundo do trabalho, o qual reproduz a dominação nas relações sociais. Do mesmo modo, poder-se-ia observar se a educação como instrumento de transformação, nesse processo, pode ampliar o conhecimento e os saberes existentes e desenvolver uma postura ativa que transforme a ação desses sujeitos. Portanto, essa formação deve ser permanente, uma vez que os sujeitos estão, permanentemente reinterpretando, redefinindo novos sentidos e modificando comportamentos.

Assim, a pesquisa propõe-se a desvendar algumas particularidades do processo de construção do SUS brasileiro e sua vivência pelos atores sociais ${ }^{2}$ na implementação da Política de EPS ${ }^{3}$ tendo como referência empírica a locorregião de Franca/SP. Mais especificamente, a pesquisa estruturou-se pelo resgate histórico da experiência inovadora de implementação dessa Política, com uma reflexão crítica sobre esse seu movimento e a participação dos atores sociais na condução desse processo por meio dos Polos de Educação Permanente em Saúde. ${ }^{4}$

1 Portaria no 198/GM/MS de 13 de fevereiro de 2004. Institui a Política Nacional de Educação Permanente em Saúde como estratégia do Sistema Único de Saúde para a formação e o desenvolvimento de trabalhadores para o setor, dá outras providências e estabelece critérios para repasse de recursos financeiros para os Projetos dos Polos.

2 Sujeitos ou atores sociais são os indivíduos (usuários, profissionais, gestores etc.) ou coletivos (instituições, órgãos, comunidades, equipes de trabalho etc.) que participam, de forma organizada, dos processos de gestão, interferindo técnica, política ou eticamente no planejamento e/ou monitoramento da saúde pública (Brasil, 2004c, p.16).

3 No texto será adotado o termo Política de EPS, referindo-se à Política de Educação Permanente em Saúde.

4 Polo de Educação Permanente em Saúde, daqui para frente citado apenas como Polo ou Polo do SUS, ambas as formas utilizadas regularmente pelos seus participantes para referir e reconhecer esse espaço. 
Para compreender a complexidade do processo de implementação da educação permanente em saúde no espaço delimitado da locorregião de Franca, respalda-se na pesquisa qualitativa. Isto porque, para Minayo (1994, p.21), é ela que "[...] trabalha com o universo de significados, motivos, aspirações, crenças, valores e atitudes, o que corresponde a um espaço mais profundo das relações, dos processos e dos fenômenos que não podem ser reduzidos à operacionalização de variáveis". As condições concretas para a efetivação dos princípios e diretrizes universalizantes de saúde geram um considerável impacto no cotidiano dos serviços prestados à população.

Como se afirmou anteriormente, para explanar o significado real dessa política e as estratégias para sua materialização nos recortes espaciais deste estudo, torna-se necessário, após levantamento bibliográfico, documental e observação em campo, adotar a abordagem qualitativa, e com ela a técnica de construção de dados a partir de entrevistas semiestruturadas, ${ }^{5}$ baseadas em um roteiro indicativo dos aspectos necessários para uma análise posterior.

$\mathrm{Na}$ organização dos dados empíricos, priorizou-se o uso da técnica de análise de conteúdo, a qual, segundo Minayo (2004), aparece como um conjunto de técnicas ${ }^{6}$ que utilizam procedimentos sistemáticos e objetivos de descrições de conteúdo das mensagens, o que possibilita descobrir os sistemas de relações, as regras de encadeamento e de associações nas falas dos sujeitos. A partir da análise do real pensado, o procedimento teórico metodológico adotado possibilitou a assimilação dos conteúdos significativos das falas. Assim é que a apropriação do real deu-se por meio dos depoimentos obtidos que acentuavam aspectos entendidos como eixos temáticos convergentes para grandes categorias de análise, quais sejam: a participação, as possibilidades de transformação da realidade, a consciência crítica e a alienação dos vários sujeitos envolvidos. Somente após a coleta de informações

5 A entrevista semiestruturada define-se, segundo Triviños (1987), como aquela que parte de certos questionamentos básicos, sustentados e informados por teorias e pressupostos que interessam ao objeto de estudo e oferecem novos questionamentos, frutos de novos pressupostos que podem emergir a partir das próprias entrevistas.

6 Seguindo metodologia exposta por Minayo (2004), a análise de conteúdo contemplou as seguintes etapas: pré-análise: quando as ideias iniciais são sistematizadas; define um plano de análise mediante material coletado na pesquisa de campo; exploração do material: definição das modalidades temáticas pelo processo de codificação das entrevistas; tratamento dos resultados, inferência e interpretação. 
obtidas no trabalho de campo é que as categorias de análise foram estabelecidas, analisadas e interpretadas conforme recomendação do instrumental (Minayo, 2004).

O procedimento investigativo teve início em novembro de 2005 e compreendeu um intenso trabalho de campo, uma vez que abrangeu 22 municípios - definido como a locorregião de Franca/SP, com uma população de 657.344 habitantes (IBGE, 2006). Importa esclarecer que o município de Franca é sede do Departamento Regional de Saúde VIII (DRS), órgão responsável pela 14a Região Administrativa da Secretaria do Estado da Saúde de São Paulo e por coordenar as atividades no âmbito regional e municipal e promover a articulação intersetorial com os municípios e organismos da sociedade civil.

Desse conteúdo, foram organizados os capítulos da pesquisa nos quais está condensada a problematização apresentada. O primeiro capítulo apresenta a construção da pesquisa e o cenário da locorregião, onde o Serviço Social tem contribuído para o desenvolvimento do SUS e suas políticas. A atuação profissional na saúde, movida pela perspectiva de defesa e ampliação dos direitos da população brasileira, mostra o compromisso ético e político e mobiliza para a luta em defesa da saúde universal e integral, com direção emancipatória e respeito para conhecer as reais condições de vida da população e buscar formas de intervir contra as injustiças sociais (Sarreta, 2008).

Assim, a ideia da pesquisa foi dimensionada durante a vivência da pesquisadora ${ }^{7}$ no processo de implementação da Política de EPS e da participação no Polo da locorregião, o que aumentou o interesse em conhecer e analisar as estratégias de trabalho adotadas para o desenvolvimento pleno das políticas públicas e seus resultados correspondentes. O estudo do tema revela, portanto, a importância da compreensão da saúde no interior do movimento mais amplo de produção e reprodução das relações capitalistas e das contradições que as constituem, e sua vinculação com as novas relações en-

7 A participação da pesquisadora deu-se como representante dos trabalhadores da saúde no Polo de EPS do Nordeste Paulista durante o ano de 2003, por meio de indicação do Secretário Municipal de Saúde de Franca. E, posteriormente, por meio de seleção pública realizada pelo Ministério da Saúde - ENSP/Fiocruz, como tutora do curso de Formação dos Facilitadores de Educação Permanente em Saúde e representando a locorregião na operacionalização e desenvolvimento das ações durante os anos de 2004 e 2005. 
tre Estado e sociedade. Ao mesmo tempo, reforça a necessidade de entendimento da forma como os sujeitos vêm vivenciando e interpretando as experiências na saúde e quais suas particularidades.

Há também a percepção, às vezes desanimadora, da extensão do País e suas diversidades locais e regionais, fazendo parecer que dificilmente o SUS será, efetivamente, implantado. A localização de Franca/SP, no noroeste do Estado de São Paulo, uma cidade mediana que tem uma rede de saúde aparentemente suficiente para suas necessidades e da região, teoricamente possibilitaria um nível de organização social favorável para a introdução de ações de saúde que atendessem à maioria da população. Por que não está dando certo é explicado, no senso comum, como uma fase inicial de implementação, levando-se em consideração que o SUS completou vinte anos, tempo demais para quem dele precisa, tempo de menos para imprimir uma mudança de direção social tão radical.

Ainda que os meios de comunicação permitam, atualmente, um livre e mais amplo acesso a todas as informações sobre os mais variados assuntos, isso nem sempre se concretiza em todos os seus matizes. Neste caso, pensando na locorregião de Franca, prejudicada pela localização geográfica, visto que está fora dos eixos tradicionais de poder no País. Por isso, sente-se, algumas vezes, que faltam maiores informações enquanto pesquisadora, longe das fontes atualizadas de construção do conhecimento e elaboração das linhas diretrizes de aplicação das políticas públicas.

Esse aspecto torna relevante a ideia de compreender e explicar como o SUS está sendo construído e resolvido no interior do País. São ponderações realizadas nos espaços acadêmicos e coletivos nascidas de inquietações com a efetivação dos princípios e diretrizes deste órgão público e de suas políticas (Sarreta \& Bertani, 2005). Compreende-se ainda que nesses espaços são fortalecidas as propostas que envolvem o entendimento do direito universal à saúde e o direcionamento do SUS, nos municípios e regiões e seus órgãos representativos.

Essas demandas atingem a todos os atores do SUS - usuários, trabalhadores, gestores e formadores, uma vez que a pesquisa em saúde precisa responder também a questões que os gestores necessitam saber, e pontos obscuros precisam ser superados, tornados visíveis pela luz do conhecimento científico. Ajustam-se, assim, as propostas do projeto de pesquisa às questões da gestão municipal e regional do SUS. Os resultados buscados têm a 
finalidade de proporcionar clareza às questões formuladas, tornando explícitos os encaminhamentos e interações com os gestores da região em pauta.

No segundo capítulo, procura-se mostrar que a Política de Educação Permanente em Saúde é fruto de uma luta coletiva na área da saúde para que a formação dos trabalhadores torne uma política pública e um compromisso do Estado brasileiro, no sentido de contribuir para transformar o modelo de atenção e consolidar o SUS. A conquista da Política de EPS, portanto, é fruto da Reforma Sanitária e de seus princípios e diretrizes para o fortalecimento da gestão participativa e da responsabilidade compartilhada em saúde.

No contexto histórico da Reforma Sanitária brasileira, o aprofundamento da democracia e da justiça, por meio de transformações contra as desigualdades e injustiças, foi se desenvolvendo um novo conceito de saúde como direito universal, em que todos os indivíduos são iguais perante essa necessidade básica. As lutas políticas durante as décadas de 1970 e 1980 acompanham o processo de democratização no País e a defesa dos direitos sociais e contribuem para a construção de um novo paradigma na saúde, envolvendo a participação da população e o reconhecimento dos cidadãos como sujeitos de direitos.

As proposições da Reforma Sanitária brasileira compreendem as responsabilidades do Estado e da própria sociedade na garantia do direito à saúde, e questionam o direcionamento do sistema capitalista dado à saúde como mercadoria, a qual deve ser vista como "[...] garantia de vida, rompendo o modelo que restringe a saúde ao diagnóstico das doenças”, e a especialistas, exigindo assim, "[...] mudança nas relações de poder, implicando em uma dimensão que politiza tanto o diagnóstico como as ações de saúde, repolitizando, assim, criticamente as políticas” (Brasil, 2006a, p.19). Portanto, a referência analítica fundamental deste estudo é o conceito de saúde adotado pela 8ª Conferência Nacional de Saúde (CNS) em 1986, como condição de vida e de trabalho da população, resultado de determinações histórico-estruturais e conjunturais da nação, que envolve as condições de acesso à alimentação, à educação, ao trabalho, à renda, à habitação e outras necessidades essenciais ao desenvolvimento humano.

A saúde é um direito que se estrutura não apenas como reconhecimento da sobrevivência individual e coletiva, implica "condições de vida articuladas biológica, cultural, social, psicológica e ambientalmente", conforme a definição da Organização Mundial de Saúde (Brasil, 2006a, p.18). O direito à saúde 
significa o reconhecimento de que todos os cidadãos têm as garantias universais dela, portanto, um direito que se afirma enquanto política pública.

É certo que as definições de saúde vêm modificando-se ao longo dos últimos anos. Seu reconhecimento como bem coletivo e direito configura uma conquista da humanidade construída

num processo de embates de concepções e de pressões dos movimentos sociais por estabelecerem uma ruptura com as desigualdades e as iniquidades das relações sociais, numa perspectiva emancipatória, levando-se em conta, evidentemente, as diferentes culturas e formas de cuidado do ser humano (Brasil, 2006a, p.18).

Os movimentos sociais que precederam a constituição democrática de 1988 na área da saúde apontavam uma nova configuração para a questão da saúde da população, vista coletiva e individualmente e sobre a qual os sujeitos envolvidos participam e tomam decisão. Desse modo, o direito à saúde é assegurado pela Constituição Federal, que, pela primeira vez na história do País, ao tratar da questão de forma abrangente, considera como "[...] direito de todos e dever do Estado garantido mediante políticas sociais e econômicas que visem à redução do risco de doença e outros agravos e o acesso universal e igualitário às ações e serviços para sua promoção, proteção e recuperação" (Brasil, 1988, p.23).

A partir da criação e regulamentação do SUS, ficou estabelecido, como objetivo do Estado brasileiro, erradicar a pobreza e formular políticas públicas para minimizar as desigualdades sociais que interferem na saúde. Considerando essa concepção de saúde, portanto, torna-se necessário pensar uma formação de trabalhadores em saúde inspirada no paradigma da promoção da saúde, que aponta para a interdisciplinaridade e intersetorialidade. Assim, a pesquisa abrange o conceito de saúde como direito humano do cidadão e dever do Estado, e a importância de não fragmentar a discussão da saúde considerando seu caráter histórico e social.

Nessa perspectiva, a pesquisa adota também a ideia de que os trabalhadores da saúde não são um recurso do SUS, ou seja, um recurso adicional que somado aos financeiros, tecnológicos e materiais resulta na produção da assistência e do cuidado. Reconhece o debate que vem sendo realizado pelos atores sociais da saúde e que na $2^{a}$ Conferência Nacional de Recursos Hu- 
manos para a Saúde (Brasil, 1993, p.25) a expressão "recursos humanos tornou-se politicamente incorreta" e passou a ser substituída por "gestão do trabalho".

Essa discussão vem sendo aprofundada nos espaços coletivos do SUS, e a expressão deixou de ser empregada, porque houve a compreensão de que os trabalhadores são atores-sujeitos da saúde (OMS, 2007). Nas palavras do secretário de Gestão do Trabalho e da Educação em Saúde do Ministério da Saúde, "[...] os trabalhadores da saúde não são um insumo adicional que se agrega aos recursos financeiros, tecnológicos e de infraestrutura para produzir serviços: são os próprios serviços de saúde" (Campos, 2006, p.10).

O terceiro capítulo mostra que, embora a consolidação do SUS e sua avançada proposta de reforçar a participação da sociedade e a descentralização dos serviços apresente-se como um novo caminho para construir-se a saúde, observa-se que as formas de encaminhar as questões no cotidiano reproduzem o modelo de atenção curativa e as práticas centralizadoras e autoritárias, historicamente predominantes nas políticas de saúde do País. Outro aspecto, também analisado, relaciona-se ao fato de que essa é a primeira oportunidade de formação dos trabalhadores da saúde pela ótica da educação permanente em saúde que se tornou uma política pública, associada à satisfação sentida na expectativa positiva e até no contentamento, principalmente dos trabalhadores da saúde, pela possibilidade de receberem informações que respondessem às necessidades vivenciadas na prática, conforme mostram Bertani et al. (2008).

Sabe-se que esse aspecto não constitui, propriamente, uma novidade, pois desde a criação e os primeiros esforços de implementação do SUS, há o imperativo de formação de recursos humanos para a saúde, na execução dos novos paradigmas apontados. Essa necessidade tem sido constantemente apontada nos espaços coletivos de debates como conferências, congressos e seminários, de onde se dirigem moções aos órgãos públicos de saúde para adequarem o atendimento e a qualidade dos serviços prestados.

Não houve, como se assinalou, uma política pública voltada a essa orientação nesse longo período anterior; apenas a prática de incentivos inconsistentes para cursos esporádicos de aperfeiçoamento e treinamento profissional, que não refletiam as condições em que se produz a prática, as dificuldades e nem as necessidades apontadas pelas novas diretrizes estabelecidas. Deste modo, a transformação de projetos e programas dispersos de capacitação, 
em Política de EPS para nortear o desenvolvimento do SUS obteve um progresso significativo nessa direção (Sarreta \& Bertani, 2006).

A participação da pesquisadora na construção desse processo na locorregião de Franca evidenciou que, mesmo considerando a orientação para o levantamento coletivo dos eixos prioritários de formação, o aspecto da participação como instrumento do processo educativo não se deu facilmente desde sua primeira colocação, e nem ao menos era notada nas reuniões do Polo. O que se observa na implementação das políticas públicas são as práticas centralizadoras e a exclusão dos sujeitos.

Ainda ponderando que o processo educacional e de mudança comportamental demanda tempo e energia, percebeu-se na implementação da Política de EPS que a todo esforço e verbas empenhadas, dois aspectos iniciais persistiram durante o processo: de um lado, como já observado anteriormente, a satisfação dos trabalhadores da saúde em serem chamados a rever e discutir a questão desta área em sua locorregião. De outro lado, porém, não foi possível verificar a ampliação dos níveis de participação nem destes trabalhadores nem da população nas decisões que envolvem a saúde de sua comunidade ou nas de controle da aplicação adequada das verbas destinadas a seu município.

Portanto, as reflexões realizadas pela pesquisadora apontam os limites das iniciativas públicas voltadas à implementação definitiva do conceito ampliado de saúde, ainda não bem elaborado e compreendido pelos sujeitos envolvidos nessa área e pela sociedade em geral. Sobretudo, esse esforço de ruptura e superação do modelo curativo não se realiza de forma simplista, representa em si uma quebra dos paradigmas tradicionais da saúde.

Diante dessas constatações conceituais primárias e observações empíricas, verifica-se que ainda não há o conhecimento apropriado do que se constitui o SUS. O aspecto mais preocupante, observado no cotidiano, é o próprio desencantamento dos trabalhadores da saúde, fazendo parecer que essa política pública é inviável para a sociedade atual. Isto leva a refletir se os trabalhadores da saúde acreditam nos princípios democráticos e participativos do SUS e, também, que motivos os levam a não acreditar no próprio potencial de transformação.

Esse aspecto, do desencantamento com o próprio trabalho, pode ter sido influenciado pela desvalorização que os trabalhadores vêm sofrendo ao longo dos anos, no interior dos serviços, notada nas condições precárias de tra- 
balho, nos salários e cargas horárias diferenciados, nas interferências político-partidárias, entre outras questões que a pesquisa buscará desvendar. Ainda nessa reflexão, há uma ideia construída socialmente de que o SUS é para pobre, e que o atendimento público não precisa de qualidade, o que leva a pensar que apenas com a crítica permanente, desvendando o processo de dominação das relações sociais e os mecanismos criados, acompanhando o movimento da sociedade, será possível desvendar essas ideias e conceitos construídos historicamente no capitalismo.

A Política de EPS aponta o fortalecimento da gestão participativa e da responsabilidade compartilhada, com dispositivos que ampliem os espaços para o exercício do diálogo, integração, participação, troca de experiências e de conhecimentos e a busca de respostas e soluções coletivas para problemas que impedem a atenção integral e de qualidade. Ao mesmo tempo, estimula a formação e o desenvolvimento de profissionais que atendam às necessidades dos serviços públicos, a partir de interesses e prioridades identificados pelos próprios sujeitos envolvidos na saúde.

A criação desses espaços democráticos dentro do SUS, os Polos - instâncias interinstitucionais e locorregionais ou rodas de gestão - para condução colegiada da política nas diversas regiões do País e com uma composição embasada no quadrilátero do SUS, demonstrou o poder de organização dos atores sociais da saúde. O quadrilátero, na compreensão da política, é configurado por gestores municipais e estaduais, formadores de instituições com curso para os trabalhadores da saúde, serviços de saúde representados pelos trabalhadores da área e pelo controle social ou movimentos sociais de participação no SUS (Brasil, 2004a). Desse modo, no quarto capítulo, a análise está centrada na construção desse processo na locorregião de Franca.

Destaca-se que a Política de EPS teve a ousadia de propor uma ação intersetorial articulada para construir um diagnóstico locorregional, com a participação dos atores sociais na corresponsabilidade de identificar as necessidades e definir as prioridades de formação dos trabalhadores da saúde a partir das necessidades de saúde. Mas por que a Educação Permanente em Saúde? De acordo com a conceituação, a EPS é uma ação pedagógica adotada para enfocar o cotidiano do trabalho em saúde, "realiza a agregação entre aprendizado, reflexão crítica sobre o trabalho e resolutividade da clínica e da promoção da saúde coletiva" (Brasil, 2004a, p.2). Um processo que leva à reflexão e autoanálise do trabalho. 
Ceccim (2005a, p.161) esclarece que "como vertente pedagógica" a educação permanente ganhou estatuto de política pública na área da saúde pela difusão da Organização Pan-Americana de Saúde (Opas) para alcançar o desenvolvimento dos sistemas de saúde na região: “[...] os serviços são organizações complexas em que somente a aprendizagem significativa será capaz de adesão dos trabalhadores nos processos de mudanças no cotidiano". A saúde tem, assim, o desafio de incorporar o processo educativo ao cotidiano de trabalho.

Dessa perspectiva, a educação permanente estimula a reflexão no mundo do trabalho e pode contribuir para melhorar a qualidade da assistência, incorporando nas ações de saúde os princípios e valores do SUS - da integralidade da atenção, da humanização do cuidado e do reconhecimento da autonomia e dos direitos dos usuários dos serviços de saúde. A construção desse aprendizado é necessária para um novo modo de fazer saúde. Assim, o objeto de investigação da pesquisa é a implementação da Política de Educação Permanente aos trabalhadores da saúde.

Importa ainda esclarecer que a Política de EPS apresenta o conceito de locorregião para referir a um novo modo de construir saúde, como um lugar aberto que considera as necessidades e as demandas dos serviços de saúde locais e regionais e a participação efetiva dos atores sociais, para disseminar a capacidade pedagógica na rede do SUS e descentralizar a gestão desse processo com configuração locorregional. Assim, a locorregião é maior que um município, mas menor que um Estado, podendo incidir em territórios de interesses comuns, cumprindo um papel de ativação de processos solidários, um sistema de serviços capaz de acolhimento, responsabilidades, resolutividade, sem nenhum suposto hierárquico entre os vários atores sociais e órgãos federados. O território constrói a ideia de responsabilidade sanitária.

Esse novo modo de construir saúde na locorregião, orientado por Ceccim (2005a, p.174), abrange a noção de território que "não é físico ou geográfico", é o "da saúde e o do trabalho", um processo para a "construção da integralidade, da humanização e da qualidade da atenção e gestão [...]”, e de "afirmação da vida pelo desenvolvimento dos usuários e da população em matéria de saúde". Ou seja, um lugar aberto com capacidade de construir uma pedagogia no cotidiano dos serviços; por isso a composição múltipla do Polo é tão importante, para ativar o "[...] aprender a aprender: experimenta- 
ção e compartilhamento de problematizações e práticas de pensamento em ato" (Ceccim, 2005a, p.175).

Uma questão que se observou desde os contatos iniciais para a realização da pesquisa foi a comprovação de que essa foi a primeira oportunidade em que a formação pela ótica da educação permanente em saúde tornou-se uma política pública, visto que exige alterações na mudança da mentalidade da "prestação de atendimento com qualidade" para "o direito do usuário à qualidade em saúde". Acredita-se que as dificuldades de aplicação dos princípios e diretrizes do SUS são consequências não só da falta de compromisso político dos gestores, da inabilidade e do pouco controle social efetivo, como também de descontinuidades dos processos motivacionais e educacionais sofridos por longo período pelos trabalhadores da saúde, notadamente da atenção primária.

Surgiu, então, a ideia de que, talvez, também acontecesse o inverso, e que os centros de decisões políticas não tivessem a informação de como o SUS está sendo resolvido no interior do Estado de São Paulo no que tange à reorganização das atuais estratégias de operacionalização e na implementação da Política de EPS. Visando garantir a realização dessa política nos municípios, foram criados os Polos do SUS, com o objetivo de desenvolver estratégias de formação em saúde para a construção de um conhecimento significativo e crítico do trabalhador da saúde, ator prioritário na formação da locorregião (Brasil, 2005a).

A implementação do Polo e sua avançada proposta de reforçar a regionalização e descentralização das ações e decisões de saúde pareciam abrir caminho para se repensar novas formas de compromisso com o SUS como um todo. Ampliavam-se de novo as racionalidades emanantes da concepção de saúde, vinculando-a por sua intersetorialidade à formação dos trabalhadores da saúde. Foi quando se acreditou ser possível e importante realizar uma investigação científica sobre a implementação da Política de Educação Permanente em Saúde na locorregião de Franca. Foram essas questões que tornaram o aporte teórico e investigativo, bem como as medidas para a implementação definitiva do Sistema Único de Saúde na locorregião, tema de interesse da atual pesquisa.

Durante o encaminhamento dessa pesquisa, foi progressivamente agrupando-se a necessidade de esclarecimentos. Como a educação permanente em saúde pode ser potencializada? Qual a possibilidade de aproveitar as ex- 
periências e saberes dos atores sociais envolvidos na saúde? Qual a inteligência que está faltando para que a formação dos trabalhadores da saúde atenda às necessidades dos serviços públicos? E, por fim, os trabalhadores acreditam no potencial de transformação? Envidaram-se esforços nessa direção, na busca de respostas que pareceram pertinentes como forma de encaminhar os resultados para a população usuária, gestores, trabalhadores da saúde e comunidade acadêmica em geral. Esse estudo deparou-se com a falta de documentação das atividades desenvolvidas pelo Polo de EPS da locorregião e ausência de um sistema de monitoramento e avaliação das ações propostas e/ou desenvolvidas.

Constatou-se que, durante o processo de implementação da Política na locorregião e no desenvolvimento das ações de EPS junto aos trabalhadores da saúde, reproduziu-se o modelo de atenção curativa e de gestão centralizadora e autoritária, pela falta de compreensão do que é a educação permanente em saúde e dos princípios que norteiam a própria política e o SUS. Também não era do conhecimento dos sujeitos envolvidos nem do montante dos recursos empenhados pelo Ministério da Saúde as prioridades de aplicação ou qualquer outra informação sobre os aspectos financeiros da implementação da Política. Por esse motivo, essa informação não consta do corpo da explicação da realidade de saúde em Franca e sua locorregião (Bertani et al. 2008).

Explicar como se dá esse processo na locorregião de Franca e prestar colaboração por meio de propostas embasadas cientificamente é a motivação do trabalho, na transformação da realidade social. Propõe-se ainda a fornecer subsídios para a consolidação das diretrizes pressupostas pelo SUS e um acréscimo de elementos para melhor estruturar as ações de formação na estratégia de educação permanente em saúde ou do "aprender a construir saúde", um desafio para os atores da saúde, como debatido por Bertani et al. (2008).

Acredita-se que a contribuição da pesquisa dê-se também na relevância dos resultados que uma iniciativa de investigação científica interinstitucional voltada para a melhoria de condições de saúde da própria comunidade pode significar, bem como que essas iniciativas fortalecem a intersetorialidade em saúde, superando a fragmentação das políticas que se revelam na universidade, nos serviços e na gestão, articulando os diferentes setores da sociedade (local e regional) na resolução de problemas. 
Foram essas reflexões que tornaram o aporte teórico e investigativo, bem como as medidas para a implementação definitiva do SUS na locorregião, as quais se tornaram inquietações da atual pesquisa. São ponderações que se têm aprofundado nos espaços acadêmicos e coletivos, preocupados com a efetivação dos princípios e das diretrizes desse órgão público e de suas políticas (Sarreta \& Bertani, 2006). Compreende-se ainda que, nesses espaços, são fortalecidas as propostas que envolvem o entendimento do direito universal à saúde e o direcionamento do SUS e seus órgãos representativos. O SUS tem claramente dois caminhos: o da privatização ou da implementação efetiva, uma questão para ser debatida e analisada profundamente.

Ao enfocar-se a ampliação da responsabilidade com a inclusão das ações de formação dos trabalhadores da saúde, pode-se dizer que, apesar dos desencantamentos, "o SUS ainda se move" (Campos, 2007b, p.302) e exige novas formas de se pensar e praticar democracia. Da universidade, demanda a capacidade de repensar as velhas formas de fazer saúde, apesar dos obstáculos, e o reforço das vantagens ao instar novos significados para a vida da população. Não há solução possível para a saúde de todos os brasileiros que não passe pelas novas propostas de revisão do modo de fazer saúde.

Uma focalização prioritária na atenção primária e na prevenção e na formação dos trabalhadores da saúde é o único caminho para conseguir-se implementar os ideais de universalização, participação comunitária e atendimento integral. $\mathrm{O}$ aporte teórico leva incisivamente a confirmar a necessidade dos novos arranjos para a sobrevida do SUS e as ações que o envolvem. Desse modo, concentra-se a atenção na temática da educação de inclusão e de cidadania.

Percebe-se, portanto, que o entendimento do SUS costuma, frequentemente, estar ligado às condições de custo-benefício na aplicação de recursos, esquecendo-se situações comunitárias de base cultural e da própria forma de gestão local. Essa é outra temática que se pretende abordar neste trabalho: a implementação das diretrizes estabelecidas constitucionalmente. Pode-se cogitar que, se o SUS encontra-se ainda muito afastado de sua realização, essa incompletude talvez se deva a fatores resultantes das formas de envolvimento dos sujeitos sociais e de aspectos resultantes de decisões provenientes de escalões superiores, não satisfazendo propriamente os anseios da população a ser beneficiada. 
A percepção de que "[...] é necessário mudar o enfoque, a maneira de pensar sobre a saúde e a atenção médica”, para Temporão (2007, p.6), leva a refletir a complexa teia de relações que envolvem o processo saúde-doença, a gestão e o trabalho na saúde, em comparação com a organização da política de saúde, com as demandas vivenciadas pelos diversos serviços e com a indústria farmacêutica e de equipamentos. Também a atenção é chamada pela compreensão das relações complexas em que os eventos, citados por meio de cenas do cotidiano, mantêm entre si e com o universo mais amplo. "Há, portanto, uma convocação para um trânsito permanente entre macro e micro questões, entre diferentes dimensões onde se tecem, cotidianamente, os encontros entre os principais atores desse processo: gestores, pacientes e profissionais da saúde" (Temporão, 2007, p.8); e o compromisso em "[...] articular a compreensão dos determinantes da saúde da população brasileira com o conjunto de providências e ações possíveis dentro da governabilidade setorial" (Temporão, 2007, p.9).

Nesse sentido, os processos de trabalho, no setor de saúde, constituíram-se a partir das condições históricas de seu desenvolvimento como política pública. E entende-se que há de se considerar, também, as dimensões tecnológicas e organizacionais (Laurell, 1989) que interferem no trabalho, tanto no setor da saúde como no mercado e nas relações sociais, em geral. As reflexões apontam para considerar o paradigma políticoassistencial que orienta a formação dos trabalhadores da saúde.

Como assinalado anteriormente, a vivência da pesquisadora no Polo de EPS da locorregião, apesar dos limites e dificuldades de construir o diálogo intersetorial, possibilitou a identificação de interesses e a construção de ações e parcerias interessantes relacionadas à Universidade Estadual Paulista (Unesp), campus de Franca, por meio do Grupo de Estudos e Pesquisas sobre Saúde, Qualidade de Vida e Relações de Trabalho (Quavisss), que conseguiu em sua experiência provocar e construir o processo da política de EPS de estabelecer parceria e intersetorialidade, quando o projeto original desta pesquisa foi encaminhado e aprovado pela Fundação de Amparo à Pesquisa do Estado de São Paulo - Fapesp, no Convênio FapespCNPq-SUS, tema "Gestão Descentralizada do Sistema Único de Saúde (SUS) - Programa Fapesp de Políticas Públicas/SUS”, do qual recebeu apoio financeiro e incentivo para seu desenvolvimento. 
Para viabilizar este projeto, realizou-se parceria com três órgãos representativos da saúde da locorregião: Universidade Estadual Paulista (Unesp), campus de Franca (Departamento de Serviço Social), a então Direção Regional da Saúde - DIR XIII (substituída pelo atual Departamento Regional de Saúde - DRS VIII), a Secretaria Municipal de Saúde de Franca e o Centro de Referência em Saúde do Trabalhador (CRST). As pesquisadoras envolvidas naquela pesquisa, 16 ao todo, fazem parte do Grupo Quavisss, cuja identidade está, preferencialmente, ligada à produção científica, na realização de pesquisas empíricas voltadas à área da saúde no município de Franca e região. A relação interna do Grupo Quavisss é de interdisciplinaridade e formação, respeitando-se o conhecimento plural construído nas investigações de campo, nos debates teóricos e nas discussões das experiências sentidas, vividas e analisadas. $\mathrm{O}$ resultado desse projeto coletivo está organizado no livro Aprendendo a construir saúde: desafios na implementação da política de educação permanente em saúde (Bertani et al., 2008), o qual é referência, neste estudo.

Deste modo, os estudos na área da saúde merecem cada vez maior atenção, não só pela importância que adquirem de ampliar o debate e análises do modo de pensar e agir dos sujeitos que aí são definidos e que vêm imprimindo significado, como pela presença significativa da população do País nessa área. O conhecimento, portanto, é um desafio e tem a finalidade de melhorar a vida das pessoas e a intenção de ampliar as alternativas apropriadas às mudanças da realidade. Torna-se, assim, necessário enfatizar que a pesquisa não perca de vista a visão interdisciplinar, a capacidade crítica e a autocrítica, colaborando com o desenvolvimento dos trabalhadores da saúde que consideram o usuário como sujeito de sua história.

Deve-se enfatizar também que, durante o desenvolvimento da pesquisa, as análises, muitas vezes, partiam do campo teórico para chegar às constatações empíricas; em outras situações, tomavam como base as experiências práticas para as reflexões teóricas, importando ressaltar que cada um dos pontos desse desenho apontava para suas contradições internas e da própria sociedade. Somente desse modo é que se pode desenvolver o hábito da práxis, a leitura e a constatação empírico-teórica da realidade, assim como a atuação no campo de prática: a área da saúde. 



\section{1 \\ A CONSTRUÇÃo DA PESOUISA}

\section{A metodologia}

A construção do percurso aqui relatado teve por base de sustentação uma pesquisa de campo realizada na rede pública de saúde da locorregião de Franca/SP. Foi circunstanciada pela vigência da Política de Educação Permanente em Saúde, implementada a partir de 2003, que impulsionou o desenvolvimento da formação dos trabalhadores da saúde. O trabalho de campo foi uma etapa que estabeleceu uma ação combinada entre levantamento bibliográfico, pesquisa documental, observações, coleta de dados e entrevistas, além de um diário de campo.

Procurou-se, assim, garantir uma visão globalizadora do processo, considerando que esta etapa da pesquisa é importante para o levantamento dos problemas, a construção teórica e a busca de proposições, baseando-se no conhecimento anteriormente construído (Seabra, 2001). O trabalho de campo apresentou-se como possibilidade de conseguir não só uma aproximação com o dado empírico que se deseja conhecer e estudar, mas "[...] também criar um conhecimento, partindo da realidade presente no campo” (Minayo, 2000, p.51).

A análise da educação permanente em saúde (EPS) como estratégia para formação dos trabalhadores visando à consolidação do Sistema Único de Saúde (SUS) requer como base a compreensão histórica que dê conta da articulação entre economia e política, produção e reprodução social, para que evite reforçar uma discussão eivada de ênfases burocráticas e tecnicistas predominantes no fazer pensar da área da saúde. 
Há, certamente, várias perspectivas teóricas a partir das quais é possível analisar as questões de saúde-doença, mas a que está sendo enfatizada neste estudo é aquela que se situa na dimensão histórica. Marx \& Engels (1987) reconhecem na Ciência da História ou Ciência Social da História, condições de abranger tanto a natureza quanto o mundo dos homens com condições de levar em conta, de forma concreta e material, as relações da vida humana, como as histórico-sociais.

A partir do modo adotado de ver o mundo, a questão fundamental para o desenvolvimento do ser social é a categoria trabalho, por meio da qual cabe aos seres humanos produzir e reproduzir sua vida material. "O primeiro pressuposto de toda a existência humana e, portanto, de toda a história, é que os homens devem estar em condições de viver para poder 'fazer história”" (Marx \& Engels, 1987, p.39). Os autores frisam que a manutenção da vida depende das condições materiais, como alimentação e habitação, e assim expõem que "[...] o primeiro ato histórico é, portanto, a produção de meios que permitam a satisfação dessas necessidades, a produção da própria vida material" (Marx \& Engels, 1987, p.39). Desse modo, a manutenção da vida humana e, por conseguinte, a construção dos meios de vida é determinada pela relação do homem com a natureza.

A capacidade criadora do homem manifesta-se no trabalho, condição especificamente humana de transformar a natureza em coisas úteis, segundo seus interesses. Essa habilidade lhe possibilita a transposição do ser meramente biológico para o social. "[...] Põe em movimento as forças naturais de seu corpo - pernas e braços, cabeça e mãos -, a fim de apropriar-se dos recursos da natureza, imprimindo-lhes vida útil à vida humana" (Marx, 2006, p.211). É, portanto, por meio da relação do homem com a transformação da natureza que ele se constrói.

Marx (2006), ao distinguir a atividade de animais (relaciona a aranha ao tecelão e a abelha ao arquiteto) e do homem, pressupõe o trabalho como uma especificidade humana em função da antecipação mental do produto final. Na Ideologia Alemã (1987), a essência dos homens aproxima-se do modo de produção e das relações sociais estabelecidas. Nesse sentido é que sublinham o caráter social e histórico da produção, ou seja, a história dos homens sustenta-se em sua maneira de produzir e em suas relações sociais. Essa dimensão do ser humano produtor, criador e histórico é a própria essência humana, que é prática e se manifesta socialmente. 
Destaca-se a relevância dos determinantes sociais para a compreensão da relação saúde-doença e seu pensar fazer dinâmico e histórico no âmbito da política pública. A política de saúde como produto histórico, ou seja, construído socialmente, apresenta movimentos demarcados pelos conflitos de classes, pelo desenvolvimento do Estado, pelas concepções intelectuais e políticas e pelas derivações institucionais daí decorrentes.

Neste contexto, Minayo (2004, p.14) chama a atenção para a questão da saúde em sua dimensão de totalidade que envolve o conjunto das relações sociais vivenciadas nas áreas de produção e das condições de trabalho e, como qualquer tema abrangente do universo cultural, deve ser entendida dentro de uma sociologia de classe.

Porém, $[\ldots]$ as condições de vida e de trabalho qualificam de forma diferenciada a maneira pela qual as classes e seus segmentos pensam, sentem e agem a respeito dela. Isso implica que, para todos os grupos, ainda que de forma específica e peculiar, a saúde e a doença envolvem uma complexa interação entre os aspectos físicos, psicológicos, sociais, ambientais da condição humana e de atribuição de significados.

Segundo Teixeira (1989, p.20), as análises dos teóricos marxistas contemporâneos introduziram os interesses de classes na análise da política social, $e^{\text {" }[\ldots] ~ c o l o c o u-s e ~ a ~ p e r s p e c t i v a ~ e ~ n e c e s s i d a d e ~ d e ~ t r a t a r ~ o ~ E s t a d o ~ d e ~ f o r-~}$ ma a comportar a análise da luta de classes”. Contudo, frisa a autora que a consideração dos conflitos de classes simplesmente não é suficiente para transpor a reificação das políticas sociais e aponta a necessidade da "[...] reflexão mais curada da própria natureza do Estado, recuperando a noção básica da contradição e de suas manifestações históricas concretas" (Teixeira, 1989, p.20).

Acerca do processo de formulação de políticas de saúde, Teixeira (1989, p.22) sublinha a adesão ao modelo que compreenda "[... ] não apenas os determinantes estruturais da intervenção estatal, contudo, mais especificamente, os processos históricos que configuram distintos padrões de relação Estado/sociedade". Assim, trata-se de um "[...] produto do desenvolvimento histórico das relações entre as forças políticas fundamentais”.

$\mathrm{Na}$ atual investigação, busca-se apreender esses elementos presentes nas falas dos sujeitos em suas múltiplas dimensões. A compreensão dialética 
implica reconhecer as possibilidades de mudança e transformação social. Foi esta, portanto, a motivação para se priorizar a abordagem metodológica, que segundo Demo (1985, p.36):

Baseia-se na observação da realidade social e na adequação a ela da visão dialética que privilegia: a) a contradição e o conflito predominando sobre a harmonia e o consenso; b) o fenômeno da transição, da mudança, do vir-a-ser sobre a estabilidade; c) o movimento histórico; d) a totalidade e a unidade dos contrários.

A postura teórico-metodológica dialética adotada nesta pesquisa considera não apenas a dinâmica interna do objeto, mas suas relações, as contradições, os conflitos, seu modo de ser e de reproduzir-se, para tornar possível assim explicar seu movimento, revelando sua essência. Esse caminho situa a dimensão histórica e considera a relevância dos determinantes sociais para a compreensão da relação saúde-doença e seu modo de pensar fazer dinâmico e histórico no âmbito da política pública.

Tratar as condições concretas da materialização da estratégia da EPS requer, primeiramente, a compreensão do processo das determinações sociais, políticas, econômicas e da produção intelectual no universo da locorregião de Franca/SP. Isto significa buscar nos alicerces da teoria marxista a base para a discussão do objetivo deste estudo. Deste modo, a partir do exercício dialético, procura-se descobrir respostas para questões que elucidem as contradições internas presentes nos seguintes pontos: o projeto que orienta a Reforma Sanitária brasileira, a criação do Sistema Único de Saúde; o processo de implementação da Política de Educação Permanente em Saúde; o compromisso dos atores sociais do SUS e, em especial, a participação dos trabalhadores da saúde. Compreende-se que essa política reflete as condições concretas para a efetivação dos princípios do SUS e um considerável impacto no cotidiano dos serviços prestados à população.

A abordagem qualitativa adotada alcança "[...] uma aproximação fundamental e de intimidade entre sujeito e objeto, uma vez que ambos são da mesma natureza: ela se volve com empatia aos motivos, às intenções, aos projetos dos atores, a partir dos quais as ações, as estruturas e as relações tornam-se significativas", esclarece Minayo (2000, p.8). Para a autora (2004, p.134), ela se torna importante para compreender "[...] as relações que se 
dão entre atores socais tanto no âmbito das instituições como dos movimentos sociais [...], para a avaliação das políticas públicas e sociais tanto do ponto de vista de sua formulação, aplicação técnica, como dos usuários a quem se destina".

Para realizar tais propósitos, foram realizadas entrevistas semiestruturadas (Triviños, 1987), as quais sempre baseadas em um roteiro que indicava os pontos que não poderiam ser deixados de fora para uma análise posterior (Apêndice A). As entrevistas semiestruturadas permitem conhecer o que o sujeito expressa sobre seus pensamentos e sentimentos do assunto, com liberdade para manifestar o que julga importante; além do mais, permitem obter respostas a indagações previamente formuladas e relevantes ao estudo em questão.

As entrevistas foram registradas em gravador com autorização formal ${ }^{1}$ dos sujeitos da pesquisa, posteriormente transcritas, para permitirem o "mergulho" na hermenêutica dos significados e na representação de cada afirmação sócio-historicamente localizada, conforme nos recomenda Minayo (2004) para esses casos. Esse procedimento possibilitou melhor interpretação das falas entre os sujeitos da pesquisa e a autora, assegurando a fidedignidade das informações e enriquecendo a coleta de dados.

Como recurso para complementar os dados da pesquisa, e pela natureza do trabalho e lotação funcional própria da pesquisadora na saúde pública municipal de Franca/SP, a observação participante foi um recurso fundamental nesse processo. Assim, deixou-se em aberto a possibilidade de utilizar diversas técnicas de abordagens e de análises, de vários sujeitos e pontos de observação, que foram estabelecidas conforme o adensamento do contato empírico, pois foi possível somente aí delinear esse quadro com maior clareza.

Essa diversificada ancoragem permite agora descrever os mecanismos adotados na estratégia da educação permanente em saúde para o encaminhamento de suas questões intrínsecas, tais como a natureza do impacto dessas ações aos trabalhadores da saúde na locorregião e os reflexos percebidos em uma eventual melhoria na atenção dos usuários do SUS.

1 Termo de Consentimento Livre e Esclarecido (TCLE), conforme determinação do Conselho de Ética em Pesquisa (Conep). Brasília, Distrito Federal. 
Para o alcance do objetivo proposto nesta pesquisa, "conhecer, analisar e explicar experiências que potencializam a educação permanente em saúde como estratégia para a formação dos trabalhadores da saúde e consolidação do Sistema Único de Saúde (SUS) na locorregião de Franca/SP”, propôs-se estudar a Política de EPS durante os anos de 2005 a 2008.

Decidiu-se dar início à análise enfocando um dos atores do SUS, os trabalhadores da saúde, não desconsiderando a importância dos usuários, gestores e formadores para a compreensão do processo em pauta. O interesse imediato nos trabalhadores da saúde deveu-se ao objeto declarado de investigação, ou seja, a formação dos trabalhadores da saúde e a utilização das novas ferramentas por meio da educação permanente e dos novos saberes trocados e desenvolvidos nos processos de trabalho.

Com essa proposição investigativa, o Polo de Educação Permanente em Saúde do Nordeste Paulista da locorregião de Franca/SP caracterizou-se como espaço representativo e de referência no processo de implementação das ações de EPS, com a função principal de integrar o quadrilátero do SUS - trabalhadores, gestores, formadores e representantes do controle social -e identificar problemas, prioridades e alternativas de formação. Desse universo, a escolha dos sujeitos da pesquisa - os trabalhadores da saúde - levou-se em consideração o objetivo proposto, os pressupostos teóricos e o movimento da realidade.

Para a seleção dos sujeitos, utilizou-se como critério a participação destes na implementação da Política, enquanto facilitadores de EPS. Em atenção a essa nova dinâmica, em 2005, o Ministério da Saúde desencadeou um processo de formação no País no Curso de Formação de Facilitadores de Educação Permanente em Saúde, por meio da Educação a Distância (EAD), com objetivo de ampliar a massa crítica capaz de atuar e desenvolver a educação permanente no sistema de saúde.

O Polo da locorregião de Franca indicou 22 facilitadores de EPS e um tutor para desencadear as ações de EPS. A indicação seguiu recomendações e critérios do Ministério da Saúde, e as vagas foram pactuadas junto ao Conselho Estadual de Secretários Municipais de Saúde (Cosems) para ações de formação e repasse de recursos financeiros previstos. ${ }^{2}$

2 Resolução nº 335, de 27 de novembro de 2003 (Brasil, 2003a). 
Importa esclarecer que os 22 facilitadores de EPS indicados para o Curso de Formação de Facilitadores de EPS não representavam o quadrilátero do SUS: 16 trabalhadores da saúde, cinco gestores e um controle social. Observa-se que a prioridade na escolha dos trabalhadores da saúde é significativa pelas próprias orientações da Política, entretanto, os formadores foram excluídos do processo, e houve uma representatividade pequena dos usuários.

Adianta-se que dos 22 facilitadores de EPS, 13 desistiram e somente nove concluíram o Curso de Formação, sendo que todos são trabalhadores da saúde. Resulta daí que, no transcorrer da pesquisa, foram entrevistados quatro sujeitos participantes do processo, uma vez que estes facilitadores de EPS são, ao mesmo tempo, trabalhadores da saúde. A título de amostragem, escolheu-se, a princípio, um sujeito envolvido no Curso de Formação programado, e posteriormente, expandiu-se o universo com vistas à construção da visão de mundo ampliada desta pesquisa.

A seleção dos quatro sujeitos, do universo de nove facilitadores de EPS, deu-se em razão da facilidade de contato e aceitação ao convite realizado pela pesquisadora. Houve o cuidado de garantir a representatividade dos municípios do Polo da locorregião, os quais não serão divulgados para preservar a identidade dos sujeitos.

Os trabalhadores da saúde selecionados responderam e contribuíram prontamente ao convite para participar do desenvolvimento da pesquisa. Percebeu-se uma grande satisfação desses sujeitos durante as entrevistas, o prazer de falar do próprio trabalho e de expressar a opinião a respeito do SUS e do processo de formação vivenciado, enfim, da satisfação de serem ouvidos. Aos sujeitos, esclareceu-se a proposta da pesquisa e foi explicitado seu caráter acadêmico, parte do processo de qualificação docente.

As entrevistas foram realizadas nos locais indicados pelos sujeitos: três no local de trabalho e uma na residência, e procurou-se resguardar a autonomia dos sujeitos e da pesquisadora ante o universo institucional. O objetivo da pesquisa foi interpretado como o de conhecer a vivência deles no cotidiano da saúde pública e a opinião sobre o SUS e a política de EPS, sendo os informantes mais qualificados porque vivenciam o trabalho nas unidades de saúde. A leitura do formulário de entrevista foi realizada, e somente após o esclarecimento de dúvidas, a entrevista foi iniciada.

Tais recursos foram fundamentais para permitir a redação deste trabalho e a honestidade das informações apresentadas, respeitando-se os princípios 
éticos ${ }^{3}$ da pesquisa em saúde. O trabalho de campo foi todo realizado pela autora, contando com auxiliar de pesquisa na transcrição das fitas gravadas. Conforme combinado, após a transcrição das entrevistas, estas foram encaminhadas aos sujeitos, para leitura e aceitação, informando que as falas poderiam ser corrigidas em relação à gramática e à ortografia, mas o conteúdo não deveria ser alterado. Portanto, o material das falas utilizado neste trabalho segue a particularidade da correção de cada sujeito.

Como diz Minayo (2004, p.109), a fala dos sujeitos “[...] é reveladora de condições estruturais, de sistemas de valores, normas e símbolos, e ao mesmo tempo, tem a magia de transmitir, através de um porta voz, as representações de grupos determinados, em condições históricas, socioeconômicas e culturais específicas".

Os quatro sujeitos entrevistados são servidores municipais e desenvolvem atividades nas unidades de saúde da locorregião no atendimento direto ao usuário e, ainda, na gestão de programas e projetos, em serviços administrativos e como representantes em conselhos de direitos, entre outras.

Todos trabalham em unidades de atenção básica diferenciadas ${ }^{4}$ e esclarecem que, apesar do enfoque curativo ainda predominante, desenvolvem ações de prevenção em saúde com grupos de usuários, atividades informativas relacionadas aos programas, serviços e recursos institucionais e comunitários existentes, visitas domiciliares (às vezes, em equipe), atendimento individual para acompanhamento. E também realizam atividades com a equipe de saúde, relacionadas à integração, informação, avaliação, planejamento, mas com diversos limites colocados pela grande demanda e limites institucionais.

Relatam que a área da saúde pública foi, além da necessidade básica de trabalhar, uma opção pessoal e profissional. Demonstram identificação e gosto pelo que fazem. Todos os quatro sujeitos têm formação superior em nível de graduação, e estes têm formação: um em aperfeiçoamento na área especí-

3 Resolução 196/96 do Ministério da Saúde (Brasil, 1996). Sendo o projeto aprovado pelo Comitê de Ética e Pesquisa da Unesp - Universidade Estadual Paulista, Faculdade de Medicina de Botucatu, campus de Botucatu.

4 Segundo o Ministério da Saúde, o Brasil registrou em 2005 um total de 44.223 Unidades Básicas de Saúde. Elas podem variar em sua formatação, adequando-se às necessidades de cada região, e podem ser: unidade de saúde da família; posto de saúde; centro de saúde/unidade básica de saúde e podem ou não oferecer pronto atendimento 24 horas; unidade móvel fluvial; unidade mista e ambulatórios de unidade hospitalar geral (Brasil, 2006b). 
fica, dois em administração pública, dois em especialização na saúde coletiva, um como conselheiro-gestor e quatro em formação em Facilitadores de EPS, o que evidencia uma busca pela formação e qualificação profissional permanente voltada para as necessidades nascidas no trabalho na saúde.

No decorrer da análise das falas, eles estão apresentados como S (sujeitos), identificando cada sujeito como S1, S2, S3 e S4, considerando a sequência de realização das entrevistas. Esclarece-se, também, que as falas dos sujeitos estão intercaladas no corpo do trabalho. O tempo de trabalho na saúde pública é de S1, 22 anos; S2, 13 anos; S3; 26 anos e S4; 10 anos, o que leva a considerar que esse tempo de trabalho demonstra conhecimento e experiência relacionada à área.

A pesquisadora, que exerce sua função como trabalhadora da saúde, se autorreconhece nas falas dos sujeitos entrevistados como protagonistas, que também o são, do próprio processo de aprendizagem da educação permanente em saúde que se procura efetivar. Enquanto se realizavam a pesquisa e as entrevistas, a pesquisadora estudava o processo, buscando construir a realidade enquanto se identificava como sujeito aprendiz.

A construção da trajetória investigativa teve como base a coleta de dados e de informações provenientes por meio da análise de: entrevistas com os trabalhadores da saúde, como descrito anteriormente; legislação vigente e políticas de saúde sobre o tema; relatórios finais das Conferências Nacionais de Saúde; relatórios da Organização Mundial de Saúde (OMS); relatórios da Organização Pan-Americana de Saúde (Opas); documentos e relatórios do Ministério da Saúde; documentos da Secretaria de Gestão do Trabalho e da Educação em Saúde; programas, projetos e/ou ações desenvolvidos sobre o tema, na locorregião; documentos do Polo de Educação Permanente do Nordeste Paulista e, pesquisa suplementar de dados (pesquisa bibliográfica, pesquisa digital em internet), os quais acrescentaram conhecimento à investigação, deram densidade ao objeto de estudo e contribuíram para explicar a trajetória adotada no processo.

$\mathrm{Na}$ organização dos dados empíricos, priorizou-se o uso da técnica de análise de conteúdo, a qual, segundo Minayo (2004), aparece como um conjunto de técnicas. ${ }^{5}$ Estas utilizam procedimentos sistemáticos e objetivos de

5 Seguindo metodologia exposta por Minayo (2004), a análise de conteúdo contemplou as seguintes etapas: pré-análise: quando as ideias iniciais são sistematizadas; define um plano de 
descrições de conteúdo das mensagens ${ }^{6}$, o que possibilita descobrir os sistemas de relações e as regras de encadeamento e de associações nas falas dos sujeitos.

Recorreu-se à discussão teórica da influência da macroestrutura sobre a saúde humana e os serviços públicos/papel do Estado, centrando o olhar pela via dos eixos temáticos evidenciados na fala dos sujeitos e na escolha sistemática de aspectos que se destacaram no objeto do estudo. É importante enfatizar que o objeto de estudo desta pesquisa configura a interface entre a formação e a compreensão do conceito ampliado de saúde, o que leva a avaliar a articulação entre a prática educacional e profissional na perspectiva do processo de trabalho.

Em seguida ao tratamento dos dados coletados, a análise e interpretação das informações apreendidas apontam para uma aproximação da realidade, permitindo sua revelação não só do aspecto descritivo e técnico, mas também do panorama político que a envolve. Tem a finalidade, conforme explica Minayo (2004, p.69), de “[...] estabelecer uma compreensão dos dados coletados; confirmar ou não os pressupostos da pesquisa e ampliar o conhecimento sobre o assunto, articulando-o ao contexto cultural da qual faz parte". Estão contidas no mesmo movimento e apontam a ideia de não criar modelos e não perder a perspectiva de totalidade.

As categorias teórico-analíticas estão continuamente inter-relacionadas na investigação, já que todas servem para explicar o mesmo acontecimento ou evento, no caso, a implementação da Política de Educação Permanente em Saúde para a consolidação do Sistema Único de Saúde (SUS) na locorregião mencionada. Assim, a análise das condições para a participação passa fundamentalmente pelas determinações materiais de trabalho (produção) e do envolvimento dos sujeitos neste processo.

Os entraves e incentivos para ocorrer essa participação servem também para informar as relações sociais, que originam e provocam possibilidades de transformações na realidade social abstrata e material que ajudam na

análise mediante material coletado na pesquisa de campo; exploração do material: definição das modalidades temáticas pelo processo de codificação das entrevistas; tratamento dos resultados, inferência e interpretação.

6 Valendo-se de uma fundamentação teórica, essa fase permite a interpretação dos resultados conforme categorias estabelecidas nas fases anteriores. 
efetivação do SUS. A formatação da relação ensino-aprendizagem, baseada no conhecimento da Política de EPS, a formação dos sujeitos, o entrosamento e a integração dos diferentes atores do SUS explicam o desenvolvimento da consciência social ou sanitária do SUS ou a manutenção das práticas alienadas. Evidencia-se, portanto, que os depoimentos dos sujeitos durante a realização das entrevistas convergiam para aspectos que foram identificados como as ideias a respeito do SUS e o compromisso com a saúde pública, nas quais se concentram as opiniões e conceitos relacionados ao trabalho no SUS enquanto política pública, seu conhecimento e funcionamento, e busca-se explorar as sugestões relacionadas ao que pode ser diferente.

Nas categorias referentes às perspectivas dos sujeitos quanto à implementação da Política de Educação Permanente em Saúde e o significado dessa formação, encontram-se expressa a relação ensino-aprendizagem, baseada no uso da metodologia da problematização recomendada e/ ou utilizada. Os resultados das experiências vivenciadas encontram-se na análise do conhecimento dessa Política e nas possibilidades para a potencialização da educação permanente, quando se procurou explorar o nível de integração dos atores sociais no Polo.

Os problemas prioritários da locorregião e o processo de seleção dos facilitadores de EPS são aspectos que remetem aos questionamentos acerca do compromisso para a construção do processo pedagógico e político na locorregião e das expectativas quanto ao SUS para a manutenção ou formação de novos saberes nas práticas de saúde. A discussão passa, portanto, pelos princípios do SUS, com privilégio do método dialético, em conexão com a consciência social e sanitária do trabalhador da saúde e dos demais atores envolvidos. Não se trata de uma construção à parte da realidade social, externa ou uma "[...] invenção fantasiosa do espírito humano", mas de um conhecimento embasado na discussão dialética defendida por Marx \& Engels (1987) e por Lukács (1989), cuja teoria se constrói na ação.

Assim, a consciência é o produto social da necessidade e da ação humana no meio sensível e na natureza, a qual se constrói na relação com os outros seres humanos dentro de determinadas condições de produção. O pressuposto fundamental é a perspectiva histórica no sentido de permanente construção, ou seja, como produto da ação e interação dos indivíduos em sociedade, na qual os fenômenos econômicos e sociais não são uniformes e iguais, 
mas se apresentam a partir do princípio do conflito e da contradição, sendo esses elementos que tornam possível a transformação da realidade.

Diante da complexidade da proposta, buscou-se apresentar os dados de forma que possibilitassem ao menos parcialmente a percepção da relevância das categorias de análise. A limitação para realizar essa explicação do real encontrou alento no comentário de Gastão Campos (1997, p.147) de que "[...] infelizmente, nem à escrita nem à fala foram concebidos o dom da multidimensionalidade. Assim caminharemos por partes, que ao fim deve ao menos projetar a silhueta do todo". Dessa maneira, e considerando o movimento da realidade, as falas estão contidas no conteúdo deste estudo, pois delas emergiram seu significado.

Os eixos localizados ainda na análise das entrevistas, tais como a participação, o envolvimento e a integração dos diversos atores do SUS no processo, consideraram as condições materiais disponibilizadas. Perceberam-se os entraves e incentivos que facilitaram e/ou impediram tanto a promoção em tempo hábil como a vinculação e contribuição possível aos cursos por alunos, professores e gestores. Outras linhas diretoras se importaram a apreender e analisar a avaliação da aplicação da Política de EPS a todos os que dela participaram, na verificação da qualidade das informações partilhadas (na maior parte das vezes, oferecidas), visando à mudança de paradigmas.

A análise dessa transformação buscou-se sob a ótica se ela teria ou não provocado uma contribuição transformadora em sua intervenção profissional nas unidades de saúde. A observância da pesquisadora centrou-se nos passos recomendados da Política de EPS, a qual exige, para sua consecução, o necessário despertar da consciência social e/ou sanitária do SUS.

Essa avaliação, aqui proposta, considera avanços, dificuldades, enfrentamentos, conflitos e consensos entre os atores sociais envolvidos e os desafios de uma nova institucionalidade no SUS. Enfim, a pesquisa tenta trazer uma análise dos resultados da formação dos trabalhadores da saúde na estratégia de educação permanente em saúde, ao mesmo tempo como processo e como impacto no fortalecimento dos princípios e diretrizes do SUS e de suas políticas.

A investigação constitui espaço, por meio da pesquisa, para a construção do conhecimento, buscando ampliar os horizontes teóricos e os debates existentes, visando apresentar contribuições sobre o tema sem a pretensão de esgotá-lo. Esse esforço de reflexão crítica está presente na visão multidisci- 
plinar que, mesmo com um eixo básico no Serviço Social, aprofunda abordagens que trazem contribuições de outras áreas das Ciências Humanas e das Ciências Sociais. Portanto, há uma relação de interdisciplinaridade e de formação, respeitando-se o conhecimento plural construído nas investigações de campo, nos debates teóricos e nas discussões das experiências sentidas, vividas e analisadas.

Deste modo, o esforço e o compromisso resultaram do desvendamento da face com que a realidade demonstrava no panorama de realização das políticas de saúde pública e nas necessidades de formação permanente em saúde. Buscou-se demonstrar a construção de seus produtos como parecer coletivo, por isso apresentou-se durante toda análise das falas dos sujeitos entrevistados os sentimentos, as opiniões, as explicações e os esclarecimentos.

\section{O cenário da pesquisa}

A partir dos anos 1980, observa-se, pela primeira vez na história do Brasil, a consolidação de um bloco ao bloco de forças políticas e culturais que se empenham na luta pelo direito à saúde que, em um espaço de pluralidade, disputaram as possibilidades de hegemonia. As forças sociais, ao uniremse, conseguiram traduzir sua visão de mundo, o que na área da saúde pode ser exemplificado pela reivindicação coletiva e pela construção de propostas situando-a, prioritariamente, no âmbito do Estado como direito de todos e com ênfase democrática.

O Sistema Único de Saúde (SUS) representou, ao final dessa década, uma mudança significativa de caráter institucional. Os princípios constitucionais estabelecidos direcionaram para a inclusão da população, excluída anteriormente pelo modelo corporativo de cidadania regulada (Santos, W. G., 1987).

Com a implementação do SUS, durante a década de 1990, a organização da atenção à saúde, no Brasil, provocou grandes inovações decorrentes do processo de descentralização, refletindo na busca de soluções relacionadas à oferta de ações e serviços de saúde em termos nacionais e no âmbito regional e municipal. No entanto, apesar desse direcionamento da política de saúde, o fortalecimento da política econômica neoliberal manteve a continuidade das desigualdades no acesso aos bens e serviços públicos como a saúde. 
No início do século XXI, a crise econômica e sociocultural, intensificada nos anos 1980, somada às mudanças econômicas e políticas de ordem mundial, chocou-se com os direitos construídos e afirmados na Constituição Federal de 1988. Esses acontecimentos causaram uma filosofia dissonante aos direitos sociais e trabalhistas garantidos legalmente, mas distanciados no plano prático, gerando várias mudanças e tendo como consequências rebatimentos no modo de reprodução material de vida e também subjetiva.

O SUS é considerado a mais importante política social inclusiva em movimento no País. Seu desenvolvimento, ainda que com diversos limites, demonstra a expectativa da sociedade na busca de atendimento à saúde com qualidade. A relevância pública das ações e serviços de saúde, definida constitucionalmente, integra uma rede regionalizada e hierarquizada para favorecer o acesso e o atendimento, a qual deve seguir as diretrizes de: "[...] descentralização, com direção única em cada esfera do governo; atendimento integral, com prioridade para as atividades preventivas, sem prejuízo dos serviços assistenciais; participação da comunidade" (Brasil, 1988, p.105).

Essa organização na gestão do SUS indica que os fatores determinantes e condicionantes da saúde, como alimentação, moradia, saneamento básico, meio ambiente, trabalho, renda, educação e outros relacionados à cultura, valores, costumes etc., devam ser realmente considerados. Essa concepção integral de saúde prevê que as ações sejam desenvolvidas sobre o ambiente, os indivíduos e as comunidades, para a proteção, a promoção e a recuperação da saúde e o desenvolvimento do trabalho intersetorial para a erradicação das causas sociais que interferem na saúde.

Portanto, compete à gestão municipal e regional da saúde cumprir os objetivos do SUS na identificação e divulgação dos fatores condicionantes e determinantes do processo saúde-doença para formular e desenvolver políticas integradas aos campos econômico e social (Brasil, 1988).

De maneira abrangente, o SUS é um sistema formado por várias instituições dos três níveis de governo - municípios, Estados e União - e pelo setor privado contratado e conveniado, compondo uma mesma corporação, implicando atuar com as mesmas normas do serviço público se houver esta contratação. Em sua constituição, abrange as ideias fundamentais do modelo de atenção, as quais constituem os princípios e diretrizes da universalidade de acesso aos serviços de saúde em todos os níveis de assistência, com referência na integralidade de assistência, entendida como conjunto articu- 
lado e contínuo das ações e atividades preventivas e curativas, individuais e coletivas, exigidos para cada caso em todos os níveis de complexidade do sistema (Brasil, 1990a).

Envolve, nessa perspectiva, a preservação da autonomia das pessoas na defesa de sua integridade física e moral, a igualdade da assistência à saúde, o direito à informação sobre sua saúde, a divulgação de informações quanto ao potencial dos serviços e sua utilização pelo usuário, a descentralização político-administrativa com direção única em cada esfera do governo - com ênfase na regionalização e hierarquização da rede de saúde.

As políticas e programas desenvolvidos pelo Ministério da Saúde seguem essas mesmas diretrizes e princípios, com a finalidade de aproximar da gestão municipal e regional a execução das ações, planejamento e avaliação. Portanto, a implementação da Política de Educação Permanente em Saúde, a partir de 2003, compreende todos esses processos previstos e assinala a construção de uma rede que considere a organização e o funcionamento horizontal do sistema de saúde, para a formação dos atores do SUS a partir das necessidades e prioridades apresentadas na realidade local e regional.

A rede no SUS é organizada de forma regionalizada e hierarquizada, com nível de complexidade crescente. A rede de cuidados progressivos à saúde supõe a ruptura com o conceito de sistema verticalizado e trabalha com a ideia de um conjunto articulado de serviços básicos, ambulatórios de especialidades e hospitalares em que "todas as ações e serviços de saúde sejam prestados, reconhecendo-se contextos e histórias de vida e assegurando adequado acolhimento e responsabilização pelos problemas de saúde das pessoas e das populações" (Brasil, 2004a, p.2).

A descentralização ${ }^{7}$ político-administrativa enfatiza, portanto, a municipalização da saúde com redistribuição de poder, competências e recursos, objetivando a identificação de necessidades de saúde, o estabelecimento de

7 Descentralização: “[...] é a transferência da gerência, da execução de ações e da prestação de serviços de saúde para instâncias de gestão e decisão mais próximas da população-alvo. No SUS, essa transferência ocorre da esfera federal para a estadual e dessas duas para a esfera municipal. Respeitando-se as atribuições específicas das três esferas de governo, expressas na Lei no 8.080/90, a municipalização com a hierarquização e a regionalização constituem o eixo estratégico da descentralização. Nos municípios de maior porte, a descentralização deve se estender aos distritos de saúde e à autonomia gerencial das unidades de saúde. (Brasil, 2005d, p.30) 
prioridades e o planejamento de ações e serviços conforme as condições de vida e de trabalho da população local e regional.

O processo de descentralização na área da saúde indica, dessa maneira, que o poder de decisão deve pertencer aos responsáveis pela execução das ações, por estar mais perto dos problemas e ter melhor conhecimento das necessidades e suas soluções. Isto facilita o direito de participação de todos os segmentos envolvidos e da administração dos serviços, o que supõe mais eficiência na solução das necessidades e demandas identificadas.

As ações e serviços de saúde que atendem à população de um município devem ser municipais, as que alcançam vários municípios devem ser estaduais, e as que são dirigidas a todo o território brasileiro são federais. Ao Ministério da Saúde cabe a direção nacional do SUS, dispondo e estabelecendo normas em nível nacional, com assessoria técnica aos estados e aos municípios.

Entre as responsabilidades estabelecidas, compete ao Ministério da Saúde o estabelecendo de normas com assessoria técnica aos Estados e municípios. É também responsável por todas as ações e serviços realizados sobre o indivíduo e o meio ambiente e por qualquer substância ou produto que é consumido e/ou utilizado pela população. Desenvolve diversas políticas e programas de saúde que visam implementar e qualificar a rede de saúde e o atendimento aos usuários do SUS e minimizar problemas que dificultam e/ ou impedem o acesso da população aos serviços e unidades. Portanto, as políticas e programas visam implementar e qualificar a rede de saúde e o atendimento aos usuários do SUS e minimizar problemas que dificultam e/ ou impedem o acesso da população aos serviços e unidades.

O SUS tem como metas desenvolver em âmbito nacional as ações previstas pelo Ministério da Saúde nas áreas da: Saúde da Mulher, Criança, Família, Controle da Hipertensão e do Diabetes Mellitus, Saúde Bucal, Eliminação da Hanseníase e Tuberculose, Saúde Mental, DST/Aids, Assistência Farmacêutica, Exames de Apoio e Diagnóstico, Vigilância em Saúde (Sanitária, Epidemiológica e Ambiental), Sistema de Informação e Controle Social, entre vários outros, conforme as necessidades regionais e populacionais. $\mathrm{O}$ atendimento é desenvolvido na atenção básica, média e alta complexidade, ambulatorial e hospitalar, por meio de serviços próprios, conveniados e/ou contratados.

Logo, a descentralização tem na regionalização e na hierarquização das ações a maneira mais eficaz de organização do SUS em relação ao atendi- 
mento e aplicação dos recursos, sendo subsídios importantes para o planejamento das ações e serviços de saúde. Assim, o melhor caminho para concretizar a descentralização da saúde é atingir eficiência, eficácia e a efetividade do SUS, por meio da articulação intersetorial e interinstitucional - de Estados e municípios, entre os municípios, e destes com as organizações existentes. A organização administrativa na área da saúde é realizada pelas Secretarias Estaduais de Saúde.

No Estado de São Paulo, essa administração é feita por meio de Departamentos Regionais de Saúde (DRS), ${ }^{8}$ responsáveis por coordenar as atividades no âmbito regional e municipal e promover a articulação intersetorial com os municípios e organismos da sociedade civil.

O mapa apresentado mostra a divisão do Estado de São Paulo nos 17 Departamentos Regionais de Saúde (DRS) existentes.

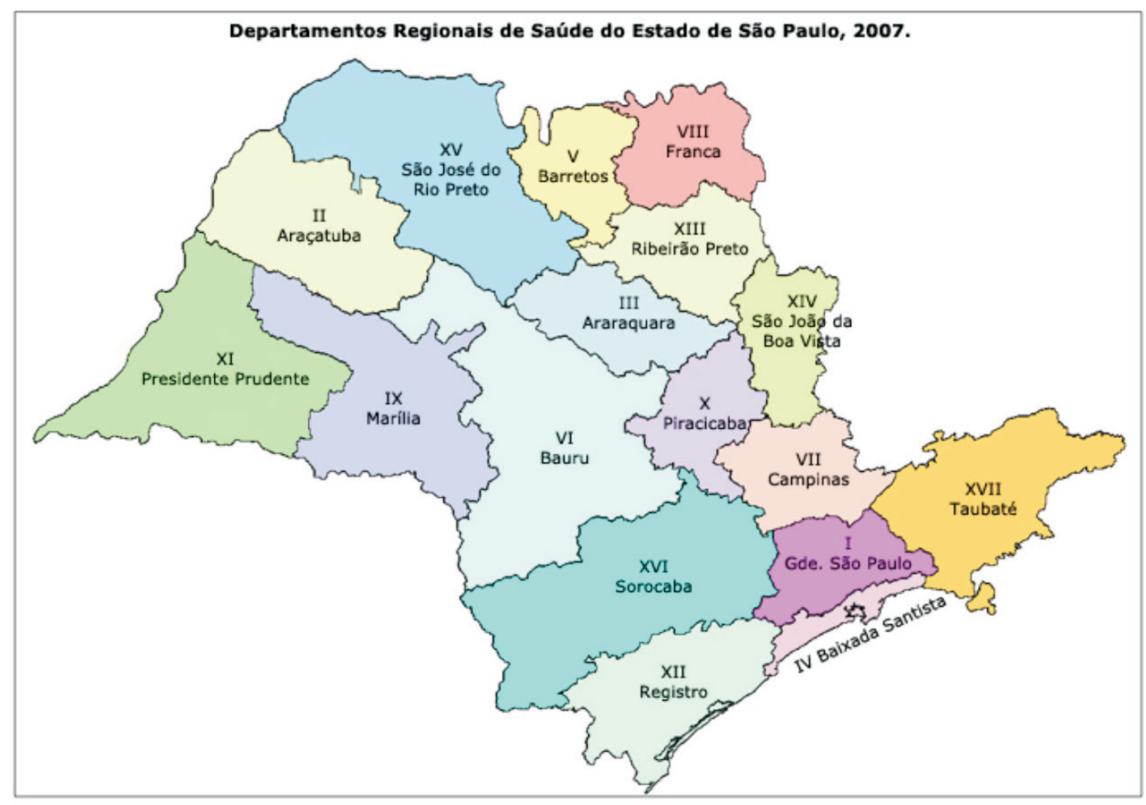

Mapa 1 - Regionalização da Saúde no Estado de São Paulo.

Fonte: Departamento Regional de Saúde (DRS), 2007.

8 Decreto no 51.433 , de 28 de dezembro de 2006. 
O município de Franca/SP é sede do Departamento Regional de Saúde (DRS) VIII, responsável pela 14a Região Administrativa do Estado de São Paulo. Sua locorregião compreende 22 municípios e uma população de 657.344 habitantes (IBGE, 2006), como se observa na distribuição a seguir:

\begin{tabular}{lr}
\hline Município & População \\
\hline Aramina & 5.280 \\
Buritizal & 3.583 \\
Cristais Paulista & 7.266 \\
Franca & 328.121 \\
Guará & 20.804 \\
Igarapava & 28.587 \\
Ipuã & 12.989 \\
Itirapuã & 5.685 \\
Ituverava & 38.681 \\
Jeriquara & 3.303 \\
Miguelópolis & 20.210 \\
Morro Agudo & 28.514 \\
Nuporanga & 6.693 \\
Orlândia & 39.467 \\
Patrocínio Paulista & 12.673 \\
Pedregulho & 15.929 \\
Restinga & 6.454 \\
Município & População \\
\hline Ribeirão Corrente & 4.363 \\
Rifaina & 3.641 \\
Sales Oliveira & 10.576 \\
São Joaquim da Barra & 45.743 \\
São José da Bela Vista & 8.782 \\
\hline Total & $\mathbf{6 5 7 . 3 4 4}$ \\
\hline Mala &
\end{tabular}

Quadro 1 - Distribuição da população na locorregião de Franca/SP.

Fonte: População estimada em 1/7/2006, pelo IBGE, 2006. 
Ao demonstrar o cenário da pesquisa, a locorregião de Franca, como Região Administrativa da Saúde, faz-se necessário pensar na descentralização das ações e serviços de saúde, que remetem à questão da regionalização e articulação intersetorial entre os municípios, do mesmo modo que possibilitam práticas alternativas de eficácia e gestão. A locorregião, além de congregar 22 municípios, está organizada em três microrregiões, ou seja:

\begin{tabular}{lll}
\hline $\begin{array}{l}\text { Microrregião 1 } \\
\text { Colegiado Três Colinas }\end{array}$ & $\begin{array}{l}\text { Microrregião 2 } \\
\text { Colegiado Alta Mogiana }\end{array}$ & $\begin{array}{l}\text { Microrregião 3 } \\
\text { Colegiado Alta Anhanguera }\end{array}$ \\
\hline Franca & Ituverava & São Joaquim da Barra \\
Cristais Paulista & Aramina & Ipuã \\
Itirapuã & Buritizal & Morro Agudo \\
Jeriquara & Guará & Nuporanga \\
Patrocínio Paulista & Igarapava & Orlândia \\
Pedregulho & Miguelópolis & Sales Oliveira \\
Restinga & & \\
Ribeirão Corrente & \\
Rifaina & & \\
São José da Bela Vista & & \\
\hline
\end{tabular}

Quadro 2 - Distribuição dos municípios da DRS VIII por microrregiões.

Fonte: Secretaria Municipal de Saúde (SMS, 2007).

Essa organização é realizada para facilitar o processo de descentralização e regionalização à gestão das ações e serviços, aos atendimentos de referência e contrarreferência e procedimentos de média e alta complexidade e de urgência e emergência. A regionalização efetiva-se, na prática, por meio do Colegiado de Gestão Regional, para programação, negociação e pactuação de todas as questões que envolvem a saúde local e regional.

O Colegiado é composto por todos os gestores de uma determinada região. Esse espaço representa uma possibilidade mais ampla e democrática para participar, efetivamente, do desenvolvimento e funcionamento do SUS nos municípios e região, podendo implicar na melhoria do acesso e da qualidade do atendimento.

Discutir a relevância da Política de Educação Permanente em Saúde(EPS) na locorregião de Franca implica conhecer algumas peculiaridades que demarcam esse espaço e que determinam as relações sociais e econômicas e, em consequência, as condições de saúde da população. Uma vez que a maioria dos municípios nessa locorregião está organizada apenas para a porta de 
entrada, ou seja, serviços de atenção básica, e apesar de alguns possuírem hospitais, os atendimentos mais complexos são realizados em Franca, Ituverava e São Joaquim da Barra, considerados ponto de referência para os municípios menores.

Ainda assim, deixam a desejar, obrigando os usuários a dirigirem-se a cidades de referência, como Ribeirão Preto, Barretos, São Paulo etc., para a realização de diversos procedimentos (exames e cirurgias, consultas em diversas especialidades), que poderiam ser realizados nos serviços de Franca e locorregião.

Os dados do IBGE (2007) mostram que a estrutura dos serviços de saúde da locorregião divide-se entre público e privado, sendo que os 22 municípios possuem um total de 130 estabelecimentos privados (55,79\%) e 103 públicos $(44,21 \%)$.

Tal constatação faz parte da discussão de Bravo (2006), que aponta dois projetos de saúde, sendo um transformador, baseado nos princípios do SUS e outro reformista, que se caracteriza pela privatização das ações e serviços de saúde. Cumpre dizer, também, que os números apresentados pelo IBGE (2007) talvez não tenham considerado os postos de atendimento das Unidades de Saúde da Família (USF). Porém, observa-se que tais dados desse órgão, se levados em consideração, não acrescentam mudanças significativas no quadro geral dos serviços de saúde da locorregião.

A região apresenta características típicas da sociedade capitalista, com aumento expressivo na base da pirâmide localizada na faixa de renda de um a quatro salários mínimos, contabilizando uma média de 70\% de famílias demandatárias das políticas públicas de assistência social no município. Nas faixas de 4,01 a 7 salários mínimos, tem-se um percentual de 15,62\%, e acima de 7 salários mínimos, concentram-se $11 \%$ da população.

Os dados apresentados no Plano Municipal de Saúde de Franca (2002) apontam o reflexo da realidade nacional, com o aumento significativo nos índices de concentração de renda, que se sabe ainda maior, considerando que os trabalhadores informais não constam nesse cálculo. No município, $65 \%$ da população é economicamente ativa. Assim, esse contingente persegue a infraestrutura do setor público e privado, principalmente o que se refere a emprego e renda. O modo como está sendo desenvolvida a principal atividade econômica no município, no caso a indústria coureiro-calçadista, como a base de sustentação econômica com predomínio no setor secundá- 
rio, que é formado pela indústria de transformação, é o que desponta por meio da confecção de calçados masculinos em couro.

Tabela 1 - Relação das unidades e dos serviços de saúde existentes na locorregião.

\begin{tabular}{|c|c|c|c|c|}
\hline Municípios & $\begin{array}{l}\text { Serviço } \\
\text { Público } \\
\text { Municipal }\end{array}$ & $\begin{array}{c}\text { Serviço } \\
\text { Público } \\
\text { Estadual/Federal }\end{array}$ & $\begin{array}{l}\text { Serviço } \\
\text { Privado }\end{array}$ & Total \\
\hline Aramina & 1 & & & 1 \\
\hline Buritizal & 1 & & & 1 \\
\hline Cristais Paulista & 2 & & & 2 \\
\hline Franca & 22 & 6 & 78 & 106 \\
\hline Guará & 6 & & 3 & 9 \\
\hline Igarapava & 5 & & 4 & 9 \\
\hline Ipuã & 4 & & 2 & 6 \\
\hline Itirapuã & 1 & & & 1 \\
\hline Ituverava & 10 & 1 & 13 & 24 \\
\hline Jeriquara & 1 & & & 1 \\
\hline Miguelópolis & 5 & & 8 & 13 \\
\hline Morro Agudo & 6 & & 2 & 8 \\
\hline Nuporanga & 2 & & 1 & 3 \\
\hline Orlândia & 5 & & 6 & 11 \\
\hline Patrocínio Paulista & 1 & & 1 & 2 \\
\hline Pedregulho & 6 & & 1 & 7 \\
\hline Restinga & 1 & & & 1 \\
\hline Ribeirão Corrente & 1 & & & 1 \\
\hline Rifaina & 1 & & & 1 \\
\hline Sales de Oliveira & 2 & & 1 & 3 \\
\hline São Joaquim da Barra & 10 & 1 & 10 & 21 \\
\hline São José da Bela Vista & 2 & & & 2 \\
\hline Total & 95 & 8 & 130 & 233 \\
\hline
\end{tabular}

Fonte: Dados disponibilizados pelo IBGE Cidades/2006. 
O aumento progressivo na faixa etária acima de 50 anos vem demonstrando um acréscimo na expectativa de vida, sendo que o envelhecimento da população é um processo visível no município. A queda nas taxas de crescimento é explicada como consequência do comportamento da fecundidade, que diminuiu de quatro filhos por mulher, em 1980, para 2,6, em 2001, e do aumento na esperança de vida ao nascer, o que indica melhoria na condição de saúde dos habitantes.

O Índice de Desenvolvimento Humano (IDH) com dados referentes ao ano de 2000 aponta 0,82, correspondente ao observado no Estado de São Paulo como um todo, e considerado alto para cidades de médio porte ${ }^{9}$ (Seade, 2007); e a cobertura de abastecimento de água tratada e esgoto sanitário são da ordem de 99,54\% e de 99,03\%, respectivamente, índices considerados importantes.

O aspecto central do estudo, a educação, ao ser delineado, demonstra que o problema do analfabetismo faz parte de 5,63\% da população com 15 anos ou mais. Agrava-se ao deparar com o índice de 60,39\% do total de pessoas com idade acima de 25 anos que tiveram menos de oito anos de estudo. $\mathrm{O}$ Ensino Médio completo em 2000 alcançou 40,61\% da população jovem de 18 a 24 anos. Como se observa, não apenas o município, mas sua locorregião tem uma população jovem com preparo insuficiente para as novas exigências das atuais configurações do mercado de trabalho, em termos de instrução formal e, portanto, "vocacionada" pela falta de alternativas, às margens do sistema produtivo, com atividades de trabalho repetitivo ou de força física.

Detendo ainda na educação, enquanto vinculada às condições de trabalho, verifica-se que os equipamentos sociais necessários para a condição da mulher/mãe trabalhar fora são insuficientes, e as creches existentes no município de Franca atendem atualmente a apenas 1.621 crianças, ao passo que os dados computados acerca da demanda demonstram a necessidade de 8.155 vagas.

9 O IDH foi criado para medir o nível de desenvolvimento humano dos países a partir de indicadores de educação (alfabetização e taxa de matrícula), longevidade (expectativa de vida ao nascer) e renda (PIB per capita). Seus valores variam de 0 (nenhum desenvolvimento humano) a 1 (desenvolvimento humano total). Países com IDH até 0,499 são considerados de desenvolvimento humano baixo; com índices entre 0,500 e 0,799 são considerados de desenvolvimento humano médio; e com índices maiores que 0,800 são considerados de desenvolvimento humano alto. Os mesmos índices se aplicam a Estados e cidades. 
Segundo Franco (2004), se a base de cálculo tivesse considerado os trabalhadores informais, a problemática seria ainda maior. Outra questão destacada pela autora é a ausência de equipamentos sociais, programas e projetos específicos, que atendam à população adolescente em suas necessidades de acompanhamento escolar, de lazer e cultura. Pode-se observar que a responsabilidade do município relativo à educação concentra-se na educação infantil.

Ao focar a atenção nas condições de saúde de Franca, a Fundação Seade (2007) demonstra que a taxa de natalidade (por mil habitantes) é de 15,60\%, e a de mortalidade infantil, 11,83\% por mil nascidos vivos. Em relação à mortalidade na infância (por mil nascidos vivos), a taxa apresentada indica o percentual de 16,97\%; para a população de 60 anos ou mais, o número chega a 3.840,83 por cem mil habitantes. Outro indicador é o índice de 7,2\% de mães adolescentes com idade inferior aos 18 anos, e o percentual de 10\% para crianças que nasceram com baixo peso (menos que $2,5 \mathrm{~kg}$ ).

O município de Franca está habilitado na condição de Gestão Plena do Sistema desde 1998, significando o repasse de recursos financeiros do Ministério da Saúde diretamente do Fundo Nacional de Saúde para o Fundo Municipal de Saúde. Tem responsabilidade na execução e controle das ações básicas de saúde, no gerenciamento de toda a rede pública ambulatorial e hospitalar e no pagamento dos prestadores contratados e conveniados ao SUS.

A sede da Secretaria Municipal de Saúde de Franca funciona em prédio próprio e gerencia todo o atendimento público de saúde oferecido, tendo como objetivo principal atender toda a população do município e da DRS VIII, garantindo os princípios do SUS e o acesso de todos os cidadãos às ações e serviços de saúde.

De acordo com o que dispõe a Lei Orgânica da Saúde, de no 8.142/90, a Secretaria Municipal de Saúde e a Prefeitura criaram o Conselho Municipal de Saúde, que deve ser preferencialmente composto por 50\% de representantes dos usuários e $50 \%$ de representantes do poder público, prestadores de serviços, entre outros, para possibilitar um processo mais democrático e participativo, em que as reuniões devem ser periódicas e abertas ao público, com pauta e datas previamente divulgadas.

A rede municipal de saúde de Franca, pública, conveniada e contratada, está estruturada e organizada com as seguintes unidades e serviços: 
Tabela 2 - Relação das unidades e serviços de saúde existentes emFranca/ SP.

Unidades e serviços de saúde de Franca

Secretaria Administrativa de Saúde

Unidade Básica de Saúde/Centro de Saúde

Unidade de Vigilância em Saúde

Clínica Especializada/Ambulatório de Especialidade

Centro de Atenção Psicossocial

Policlínica

Unidade Móvel de Nível Pré-Hospitalar - Urgência/Emergência

Unidade Móvel Terrestre

Unidade de Apoio Diagnose e Terapia (SADT isolado)

Pronto Socorro Geral

Centro de Atenção de Hemoterapia e/ou Hematológica

Central de Regulação de Serviços de Saúde

Farmácia municipal

Hospital Especializado

Hospital Geral

Total

Fonte: Secretaria de Atenção à Saúde - DATSUS (2007)
Quantidade

1

4

Observa-se que o processo desencadeado pela descentralização e municipalização da atenção à saúde favoreceu o acesso da população aos serviços e ampliou positivamente, a rede física e as ações de saúde. Os esforços desde a criação do SUS têm produzido evidentes avanços na descentralização da gestão, na integralidade da atenção, na participação da comunidade e na regulação de serviços. Entretanto, os caminhos apontam que é necessário manter, priorizar e ampliar a cobertura de serviços e ações de saúde de boa qualidade e, principalmente, promover transformações políticas e éticas que resultem na melhoria da qualidade de saúde da população.

Conclui-se, assim, a apresentação do retrato da cidade-sede e os municípios da DRSVIII, o cenário de onde partiu e foi realizada a ação investigativa. 


\section{O Serviço Social no cenário do SUS}

Neste cenário, a pesquisadora tem sua trajetória profissional no Sistema Único de Saúde (SUS) de Franca assinalada por preocupações com vista a potencializar transformações no cotidiano, para ampliar as possibilidades de atendimento às necessidades sociais apresentadas ao Serviço Social pelos usuários. Embora o Serviço Social não seja objeto de interesse central desta pesquisa, subsidia esta análise. A profissão tem um posicionamento claro na defesa do Sistema Único de Saúde (SUS) como política pública universal e integral.

A implementação do SUS e seu desenvolvimento no País vêm requerendo a participação do assistente social no processo de gestão da saúde, atuando na (re) organização de serviços de saúde, planejamento, execução e avaliação de programas e políticas, no controle social, entre outras demandas que expressam a abrangência do conceito de saúde vigente, especialmente nos municípios onde se concretizam as ações de saúde, buscando fortalecer a perspectiva da universalização do acesso a bens e serviços relativo às políticas sociais (Bravo, 2006).

O Serviço Social tem mantido participação ativa na defesa do direito universal à saúde e das políticas sociais e públicas. A profissão vem produzindo conhecimentos ${ }^{10}$ e experiências para o enfrentamento dos desafios postos/ vivenciados na área da saúde, provocando o alargamento da prática profissional, que, associada à produção de conhecimentos e à qualificação profissional, vem legitimando o trabalho e ampliando as possibilidades de acesso e de inclusão social, especialmente nos municípios onde se realiza efetivamente o trabalho por meio das ações de saúde (Sarreta \& Bertani, 2006). O Serviço Social se sobressai no endosso ao reconhecimento dos fatores condicionantes e determinantes e da saúde da população - trabalho, renda, alimentação, moradia, educação, saneamento básico, acesso aos bens e serviços essenciais, como expressões da questão social.

São avanços relacionados ao compromisso da categoria profissional na busca de qualidade do trabalho, na produção teórico-científica, mas, além

10 Para aprofundar este estudo ver artigo de Bravo (2004) "Reforma sanitária e projeto éticopolítico do Serviço Social: elementos para o debate", quando analisa a produção do Serviço Social área saúde. 
do mais, no endosso ao reconhecimento de que a saúde, em seu sentido mais abrangente, é a resultante das condições de vida e de trabalho da população. É, assim, o resultado de organização social da produção, a qual pode gerar grandes desigualdades nos níveis de vida (Brasil, 1988).

O Serviço Social brasileiro apresenta um projeto profissional construído e legitimado pelo debate da categoria, contemplando o pluralismo como um elemento fundamental tanto da sociedade quanto do exercício profissional para sua consolidação. O projeto tem o reconhecimento da liberdade como valor central, como possibilidade de escolha entre alternativas concretas, daí o compromisso com a autonomia e a emancipação dos sujeitos (Netto, 1999). Os valores, ideias, opções, éticas e políticas que caracterizam o projeto profissional assinalam o compromisso com os interesses e as necessidades da classe trabalhadora brasileira, portanto, para Netto (1999), antagônico ao projeto defensor do neoliberalismo, que vem promovendo a redução dos direitos sociais, a privatização do Estado, o sucateamento dos serviços públicos, o enxugamento do papel do Estado e a redução das políticas sociais. As consequências desse processo na vida social é o desemprego, a exclusão social, o aprofundamento das desigualdades provocado pela concentração da riqueza e da renda, e, consequentemente, de desproteção social.

O desempenho profissional, assim como os aportes teóricos, metodológicos e ideológicos, estão marcados pela busca de uma referência para subsidiar a análise da realidade considerando sua historicidade. Isto autorizou à profissão constituir uma interlocução com as ciências sociais e outras áreas do conhecimento, na análise de Netto (1999). A formação generalista possibilita, portanto, apreender as questões sociais com uma base teórico-metodológica direcionada à compreensão dos processos relacionados à realidade brasileira, contexto em que se gestam as políticas sociais, inclusive a da saúde.

As proposições enunciadas no projeto ético-político do Serviço Social, materializadas no Código de Ética de 1993, estão articuladas ao projeto da Reforma Sanitária brasileira, visando efetivar a universalidade do acesso à saúde por meio de políticas públicas efetivas. Para Bravo \& Matos (2004), são projetos que enunciam princípios e diretrizes para a construção de relações democráticas, com base na liberdade e participação ativa dos sujeitos sociais, na perspectiva do desenvolvimento da autonomia e emancipação dos sujeitos, de ruptura com práticas autoritárias, centralizadoras e assistencialistas. 
Ao estudar as profissões da saúde, Bravo \& Matos (2004, p.56) afirmam que o Código de Ética do assistente social “[...] encontra-se em sintonia com as garantias constitucionais, na defesa de princípios e valores de ordem humanística, libertária, democrática e igualitária”. Destacam o reconhecimento da categoria profissional aos usuários ${ }^{11}$ dos serviços de saúde como sujeitos protagonistas.

As demais profissões da saúde, entretanto, mantêm Códigos de Ética baseados em princípios abstratos e conservadores, analisam Bravo \& Matos (2004, p.48), "[...] e não se posicionam em favor dos interesses da maioria dos brasileiros usuários dos serviços de saúde". Para as autoras, os avanços alcançados no Serviço Social têm como base o debate do direcionamento ético-político que vincula a profissão a um projeto societário que propõe a construção de uma nova sociedade, mais justa, sem exploração e sem dominação, opções que reafirmam a defesa dos direitos humanos.

O ideário que orienta a Reforma Sanitária brasileira, o qual sustenta a construção do SUS, tem sua referência na concepção integral de saúde para superar o modelo curativo formado nos ideais capitalistas de atender aos interesses e às demandas do mercado. Para tanto, considera as responsabilidades do Estado na implementação de políticas sociais e ações intersetoriais para o desenvolvimento de uma política de saúde que programe medidas eficazes para reduzir as desigualdades sociais, na perspectiva de qualidade de vida.

A Reforma Sanitária brasileira, na análise de Bravo (1996), apresenta a cidadania como um componente central em que a descentralização do processo decisório valoriza as esferas estadual e municipal, e a democratização do poder local efetiva a participação popular na gestão do SUS. O reconhecimento da saúde como um direito de todos e um dever do Estado foi, portanto, uma conquista da sociedade que, organizadamente, participou do movimento da Reforma Sanitária e lutou pela universalização, descentralização e participação social como elementos essenciais nesse processo na área da saúde.

11 Consideram-se usuários "os seguimentos integrantes da classe trabalhadora, que enquanto sujeitos de direito, agem, empreendem ações, intervêm, lutam, reivindicam, implementam, no sentido de usufruiu e/ou desfrutar de alguma coisa coletiva, ligada a um serviço público ou particular, dessa forma podendo demandar os serviços prestados" e exercer sua autonomia (Vasconcelos, 2002, p.47). 
A política pública de saúde é o setor que, historicamente, mais tem absorvido profissionais de Serviço Social, conforme relata Bravo (2006, p.39); "[...] a quarta maior categoria no âmbito do SUS". O reconhecimento do assistente social como integrante da equipe de saúde vem se construindo por meio da inserção nas políticas e programas de saúde desde o seu surgimento, apresentando-se, hoje, amplamente inserido nos serviços e programas de saúde. Para Martinelli (2000, p.56), essa relação é constitutiva na construção da identidade profissional, fortalecida na defesa do direito universal à saúde e do SUS como política pública e, desse modo, "[...] é uma profissão necessária em uma perspectiva interdisciplinar, pois contribui para que a equipe de saúde desenvolva ações que considerem as necessidades da população".

Em 1997, o Conselho Nacional de Saúde ${ }^{12}$ reconheceu o assistente social como profissional da saúde, entre outras profissões, e delegou ao Conselho Federal de Serviço Social (CFESS) sua caracterização. Entre as atribuições descritas, o CFESS (1999, p.1) assegura que a profissão não é exclusiva da saúde, "[...] mas qualifica o profissional a atuar com competência nas diferentes dimensões da questão social no âmbito das políticas sociais, inclusive da saúde", e

a partir da 8 a Conferência Nacional de Saúde, um novo conceito de saúde foi construído, ampliando a compreensão da relação saúde-doença, como decorrência das condições de vida e de trabalho; [...] atribui-se ao assistente social, enquanto profissional da saúde, a intervenção junto aos fenômenos sócio-culturais e econômicos que reduzam a eficácia dos programas de prestação de serviços nos níveis de promoção, proteção e/ou recuperação da saúde; [...] em sua prática profissional contribui para o atendimento das demandas imediatas da população, além de facilitar o seu acesso às informações e ações educativas para que a saúde possa ser percebida como produto das condições gerais de vida e da dinâmica das relações sociais, econômicas e políticas do País; [...] para a consolidação dos princípios e objetivos do Sistema Único de Saúde, é imprescindível a efetivação do Controle Social e o Assistente Social, com base no seu compromisso ético-político, tem focalizado suas atividades para uma ação técnico-política que contribua para viabilizar a participação popular, a democratização das instituições, o fortalecimento dos Conselhos de Saúde e a ampliação dos direitos sociais [...]. (CFESS, 1999, p.1)

12 Resolução no 218, de 3 de março de 1997. 
As atribuições do assistente social na área da saúde ${ }^{13}$ constituem um instrumento importante na construção de estratégias para o exercício profissional e a busca de alternativas visando ao atendimento das necessidades sociais apresentadas pelos usuários nos serviços de saúde. Estão pautadas no conceito de saúde inscrito na Constituição Federal (1988), na formação generalista do assistente social e no compromisso ético-político anunciado no Código de Ética da profissão, que reafirma seu posicionamento em favor da equidade e justiça social que assegure universalidade de acesso relativo às ações e serviços de saúde, bem como sua gestão democrática.

Ainda, ressaltam a perspectiva interdisciplinar para a atenção integral, juntamente com ações intersetoriais e comunitárias que se aproximem do cotidiano da população e ampliem o conhecimento da realidade local e regional. O desenvolvimento de estratégias programadas em equipe possibilita a compreensão da saúde pela sociedade como direito e questão de cidadania e fortalece o paradigma que considera a saúde um elemento central da organização e desenvolvimento social, econômico e político do País.

Ao valorizar a perspectiva interdisciplinar e intersetorial nas relações de trabalho, a fim de garantir a atenção às necessidades da população usuária, na mediação entre seus interesses e a prestação de serviços, e ao desenvolver atividades profissionais específicas - plantão, avaliação socioeconômica, assistência material, entrevista, trabalho com grupos, visitas domiciliares entre outras -, o assistente social ajuda a população a ter acesso à saúde (Sarreta \& Bertani, 2006).

Isso pode ser observado em diversos aspectos referenciados no projeto ético-político profissional. Um desses aspectos acontece pela facilidade de acesso do usuário ao assistente social nas unidades de saúde, no acolhimento, na escuta diferenciada, na divulgação e informação de ações e serviços de saúde e dos programas desenvolvidos pelo profissional. Outro aspecto é o desenvolvimento da capacidade de identificação das demandas no âmbito da saúde e de extrair dessas demandas as reais necessidades sociais e de saúde, apontando a formulação e execução de políticas sociais, projetos e programas como um direito.

Nesta referência, o assistente social insere-se no processo de trabalho da saúde atuando na construção de estratégias que busquem criar experiências

13 Resolução nº 383, de 29 de março de 1999. 
e aproximar as ações desenvolvidas no SUS com as demais políticas sociais. O incremento de estratégias programadas em equipe possibilita a compreensão da saúde pela sociedade como direito e questão de cidadania, e fortalece o paradigma que considera a saúde um elemento central do desenvolvimento social, econômico e político do País. Assim, ao reconhecer a saúde como resultado das condições econômicas, políticas, sociais e culturais, o Serviço Social passa a fazer parte do conjunto de profissões necessárias à identificação e análise dos fatores que intervêm no processo saúde-doença.

É dessa perspectiva que o trabalho do assistente social na área da saúde busca o enfrentamento das questões sociais na saúde visando ao atendimento das necessidades apresentadas pelos usuários, ressaltam Bravo \& Matos (2004, p.17), e que "[...] queira ter como norte o Projeto Ético-Político deve, necessariamente, estar articulado ao Projeto da Reforma Sanitária”. Portanto, é na referência desses projetos que a profissão pode fornecer subsídios para que o usuário se fortaleça e participe do controle social na saúde, ampliando assim " [...] os canais de interferência da população na coisa pública, de modo a permitir maior controle por parte da sociedade nas decisões que lhes dizem respeito" (Iamamoto, 2006, p.126).

São procedimentos significativos no cotidiano, que se aperfeiçoam pela busca do conhecimento e do aprimoramento técnico-operativo e teóricometodológico com vista ao fortalecimento do trabalho. São funções e respostas que a profissão vai desenvolvendo a partir das condições apresentadas pela população e que acabam influenciando as demandas institucionais e legitimam o projeto profissional na superação da situação atual. É nessa intencionalidade de superação das desigualdades e injustiças sociais que está posta a capacidade de transformação.

Ao imprimir uma postura investigativa no trabalho, o assistente social fortalece a atividade profissional determinada e influenciada pela realidade social. E, ao valorizar a atividade científica por meio da pesquisa, gera dados ligados às condições de vida da população, à reprodução das relações sociais e à implementação das políticas sociais. As informações de experiências desenvolvidas e socializadas podem contribuir na elaboração de propostas mais apropriadas às necessidades sociais.

A amplitude desse processo alcança-se com a observação constante e registro sistemático dos aspectos da realidade que se manifestam por meio dos processos sociais, na organização do conhecimento dado pela experiência, 
tornando-o mais legítimo. Ao mesmo tempo, transforma o exercício profissional e valoriza seu significado junto às demandas sociais, buscando estratégias que atualizam, revitalizam e redirecionam o trabalho. A reflexão crítica realimenta a própria condição do trabalho, contribui para desenvolver o potencial criativo e a capacidade de transformar seu direcionamento (Almeida, 2006; Marsiglia, 2006).

A adoção desses elementos nas experiências vivenciadas pode contribuir para que os profissionais desenvolvam seu potencial criativo e a capacidade de transformar o direcionamento do trabalho. $\mathrm{O}$ aprofundamento científico sobre os determinantes do trabalho profissional e dos instrumentos próprios da profissão ajuda na elaboração de propostas mais apropriadas às necessidades sociais. A oportunidade de experimentar novos caminhos para a autonomia no exercício profissional pode dimensionar também o trabalho do assistente social no SUS, ao adotar atitudes no cotidiano para exercitar a prática contínua de documentação do trabalho, planejamento em equipe, visando ao desenvolvimento de ações e programas para a inclusão social dos usuários.

A organização de um plano de trabalho como subsídio que compreenda as etapas e conteúdos do processo científico (objetivos, metodologia, resultados alcançados e avaliação), o estudo e elaboração de instrumental e procedimentos adequados à realidade e local de trabalho é uma alternativa para ampliar a ação e desenvolver formas de atuação efetiva nos conselhos de direitos, como espaço legítimo que favorece o controle social dentro do SUS.

A construção da práxis fundamenta-se a partir desse contato com a realidade social, suas contradições e possibilidades. Na dialética da práxis, o trabalho é influenciado pelo senso comum, com saber acrítico, imediatista, marcado pela falta de profundidade. É quando a ausência da revisão, com conteúdos teóricos em confronto com a prática, pode levar ao desprezo de instrumentos e técnicas apropriadas ao exercício profissional, produzindo um caráter assistencialista e empírico ao trabalho, distanciando-o dos critérios de cientificidade da ação profissional.

A formação e qualificação profissional permanente, para atualização e fortalecimento do referencial teórico-metodológico e instrumentalização da análise e da intervenção na realidade social, torna-se uma necessidade pontual. Realiza-se como um processo de ação-reflexão-ação acerca dos limites, dos avanços e da contribuição efetiva da profissão na área da saúde, imprimindo-lhe maior visibilidade institucional e social. 
O exercício profissional fundamentado nessa perspectiva de direitos coletivos envolve uma dimensão política, ética e técnica, na busca de alternativas para contribuir com o processo de democratização dos serviços públicos. Entretanto, o projeto ético-político não se defende apenas com argumento teórico, pois é nas relações estabelecidas que se materializa. A postura dialogada, como um caminho promissor para refletir as questões acerca da realidade social, busca encontrar alternativas para materializar os princípios e diretrizes do projeto do Serviço Social e do projeto da Reforma Sanitária brasileira.

Na reflexão de Iamamoto (2006), as possibilidades são dadas na realidade, mas não são automaticamente transformadas em alternativas profissionais. Cabe aos assistentes sociais apropriar-se dessas possibilidades e, como sujeitos, transformá-las em projetos de trabalho. A prática educativa é inerente à atividade profissional do assistente social, que acumula experiências na dinamização de ambientes coletivos, na realização de grupos, na democratização dos espaços institucionais e como subsídio que fortalece o controle social, a participação e a construção do processo democrático dentro dos serviços de saúde.

Contudo, na prática educativa, a instrumentalização política e intelectual dos sujeitos não garante sua emancipação, já que solicita que sejam reflexivas, dialogadas, participativas, organizativas e informativas, direcionadas para uma aprendizagem significativa tanto dos usuários como dos trabalhadores da saúde (Bravo \& Matos, 2004). Trabalhar nessa perspectiva significa fortalecer e instrumentalizar a população para o exercício de cidadania, e os próprios trabalhadores da saúde para que tenham uma nova relação com o trabalho e a população. É na democratização dos espaços dos serviços, espaços que permitem a construção do conhecimento, da interação e da troca, que trabalhadores e usuários podem compartilhar conhecimentos entre si. A educação em saúde é, portanto, uma condição para "aprender a participar", refletir ideias, costumes, saberes, uma condição efetiva para o êxito do SUS.

Acredita-se que por meio de um processo de educação permanente na área da saúde torna-se possível desenvolver potencialidades e novas habilidades, além de estimular a capacidade de crítica, de organização e de luta pela garantia de direitos, na sociedade atual. A ruptura com as formas verticalizadas de relacionar-se na saúde exige pensar em uma "educação para a autonomia” (Freire, 2006), a qual possibilite aos sujeitos sociais o exercício 
do conhecimento, da reflexão e da decisão, para ampliar as possibilidades de participação na vida em sociedade. Ao acreditar e investir no desenvolvimento dos sujeitos sociais, emerge o potencial transformador sobre suas ações no mundo.

Essa perspectiva de compromisso com a qualidade dos serviços prestados na saúde e de desenvolvimento dos trabalhadores está explicitada no projeto profissional do Serviço Social como um caminho para a emancipação dos indivíduos sociais, o que remete ao investimento na formação profissional dos atores sociais da saúde, como viabilização ideológica contrahegemônica ao projeto neoliberal do capitalismo.

Destaca-se, nessa reflexão, que o Conselho Federal de Serviço Social (CFESS) possui reconhecimento nacional como entidade combativa na defesa das políticas sociais públicas. Nas últimas décadas, ele vem participando ativamente de diversos espaços na defesa do direito social à saúde e na construção de estratégias que reafirmam o SUS como política pública de Estado, como analisam Bravo \& Matos (2004).

A participação da categoria profissional, juntamente com seus órgãos representativos na implementação do SUS e de suas políticas, tem sido acompanhada também das indicações para a formação profissional referente. Ao longo das últimas décadas, as discussões sobre a política de saúde pública e a necessidade de adequar a formação profissional têm sido ampliadas e fortalecidas. A responsabilidade de "ordenar a formação de recursos humanos na área da saúde” está prevista no artigo 200 da Constituição Federal, resultado das propostas preconizadas pelo movimento de Reforma Sanitária brasileira desde os anos 1970.

O Ministério da Saúde, ao "[...] incorporar algumas críticas dos trabalhadores e intelectuais da área da saúde coletiva sobre os fundamentos que orientam o Sistema Único de Saúde, decide incentivar mudanças nos cursos de graduação das chamadas profissões da saúde [...]” (Mota, 2006, p.7, grifo do autor). De acordo com a Política de Educação Permanente em Saúde, seu objetivo central é a transformação das práticas de saúde e das práticas profissionais e da própria organização do trabalho, para que sejam estruturadas a partir do próprio processo de trabalho. Aponta várias estratégias para mudanças e qualificação da atenção à saúde, das organizações e dos serviços, dos processos formativos e das práticas pedagógicas, para adequar às necessidades e dificuldades do sistema público de saúde (Brasil, 2004a). 
Atualmente, existe uma movimentação intersetorial entre o Ministério da Saúde e o Ministério da Educação, no sentido de discutir e orientar mudanças na graduação das profissões da área da saúde, para implementação de diretrizes curriculares nacionais e renovação dos projetos pedagógicos dos cursos. Essa parceria apresenta a intenção de adequar a formação profissional e o desenvolvimento de recursos humanos em saúde, para que estejam vinculados aos princípios da integralidade da atenção e respondam às necessidades dos serviços de saúde.

A discussão crítica dessa articulação saúde/educação, enquanto políticas balizadoras da formação de profissionais de saúde, tem sido acompanhada em conjunto com as Unidades de Ensino do País, associações, grupos de profissionais, como o Fórum Nacional das Associações Brasileiras de Ensino das Profissões da Saúde (FNEPAS) e a Associação Brasileira de Ensino e Pesquisa em Serviço Social (Abepss), processo profundamente analisado por distintos atores participantes (Mota, 2006).

A Política de EPS materializa as reivindicações coletivas da saúde pública brasileira e a valorização dos trabalhadores da saúde. Mostra-se avançada e consoante com as diretrizes e princípios do SUS e com as orientações da Organização Pan-Americana de Saúde (Opas, 1994 apud OMS, 2007) e da Organização Mundial de Saúde (OMS, 2007), ao adotar a Educação Permanente em Saúde como estratégia de aprendizagem, tendo como base os processos de trabalho, valorizando as vivências e experiências dos sujeitos sociais.

Portanto, a Política apresenta elementos emancipatórios, sobretudo ao criar um espaço democrático no SUS, os Polos de EPS, para implementar as ações previstas nas diversas regiões do País a partir da gestão colegiada dos atores da saúde - trabalhadores, gestores, formadores e usuários. A integração intersetorial é um dos grandes avanços colocados pela política de EPS, o que está sendo debatido desde a década de 1970. Ao ser reconhecida pelo governo federal, abre espaço para que o conceito ampliado de saúde materialize-se.

Outro aspecto a ser destacado é a educação permanente em saúde, que se mostra relevante uma vez que pode construir um processo que articula a formação profissional aos avanços e experiências acumuladas na política pública de saúde. Diante das investidas do projeto neoliberal no desmonte das conquistas historicamente construídas, torna-se necessário investir em 
uma formação profissional crítica que estabeleça nos serviços de saúde uma postura de atuação profissional que supere o papel de reprodução e manutenção e descompromisso com os interesses e necessidades sociais.

A reversão desse processo passa, inevitavelmente, pela formação permanente dos atores sociais da saúde, abrangendo a interdisciplinaridade profissional, e não menos, a participação de todos na produção de uma vida mais saudável e humana. Assim, referenciados no projeto da Reforma Sanitária brasileira, os trabalhadores da saúde têm a possibilidade de construir um novo significado de relação com as atribuições históricas verticalizadas das relações na saúde, para superação das atividades fragmentadas, repetitivas e burocráticas e descoladas do movimento transformador da sociedade, para que, desse modo, o exercício profissional na saúde contribua efetivamente para o acesso dos usuários às ações e serviços e que, ao mesmo tempo, favoreça a formação de uma consciência coletiva e questionadora dos sujeitos sociais.

As reflexões do trabalho na área da saúde assinalam, portanto, a busca de respostas para problemas que impedem o acesso universal e integral à saúde com qualidade e resolutividade, conforme garantido pelo SUS, o que leva ao interesse de uma análise que permita a compreensão sócio-histórica do direcionamento dado pela orientação neoliberal nas políticas sociais e sua capacidade de introjeção nas pessoas, para assim poder explicar a relação, ou não, com a desmotivação dos trabalhadores da saúde e de desvalorização do próprio trabalho. O que passa também pela crítica do valor atribuído à saúde pelo capitalismo, colocada no mercado como um produto a ser consumido, ou melhor, uma mercadoria à disposição do capital.

Os questionamentos acerca do padrão assistencial predominante na saúde, caracterizado tanto por práticas curativas e centradas no médico e nas tecnologias, um modelo que focaliza a doença e não a promoção da saúde, quanto pelo distanciamento entre profissionais e usuários, levam a ampliar a compreensão do real significado da política social no capitalismo. Entende-se, assim, entender como a política de saúde está estruturada para selecionar e excluir, ao invés de incluir e promover, uma vez que seu funcionamento tem levado a população brasileira a valorizar o modelo privatista.

Isso leva a questionar que saúde é essa que está sendo desenvolvida. E mais ainda, é possível um novo modo de construir saúde? Já que as análises de vários autores afirmam que o SUS brasileiro é considerado, nas palavras 
de Nelson Santos (2008, p.3), "[...] o maior projeto público de inclusão social em menos de duas décadas" no País. O autor enumera os avanços alcançados com o Sistema e os recursos colocados à disposição da população com o processo de descentralização das ações e serviços de saúde, ${ }^{14}$ mas lembra que a "[...] ênfase nas ações de promoção da saúde não gerou, ainda, os resultados que dela se esperam".

Nessa análise, Gastão Campos (2007b) defende a grande conquista histórica do Brasil na construção de um sistema de saúde com princípio universal, dentro do modelo neoliberal privatista, e lembra que o SUS está na contramão desse processo. Para ele, o SUS não é um plano de saúde, é uma política de Estado e não de governo, um projeto de reforma do Estado brasileiro, solidário, inclusivo, portanto, a ser efetivado ou não pela sociedade brasileira.

Em seus estudos, o autor destaca os avanços consideráveis, em termos de acesso, provocados na atenção primária à saúde pela estratégia Saúde da Família, que se espalha por todo o território brasileiro. Avalia que, a partir da década de 1990, os indicadores de saúde melhoraram no que se refere à mortalidade infantil, hipertensão, pré-natal, ressaltando que o sistema tem potencial de transformar a realidade de saúde no País. Entretanto, ainda não é o ideal. Exemplifica que a cobertura da Saúde da Família, principal estratégia para a mudança do modelo de atenção, que não atingiu ainda $80 \%$ da população brasileira, tem sua implementação heterogênea, entre outras análises (Campos, 2006b). O desafio, para ele, de organizar o nível de atenção básica nessa estratégia representa na prática uma mudança na visão do usuário, com humanização, acolhimento e vínculo, rompendo o modelo hospitalocêntrico e privatista.

Outro grande desafio, relacionado diretamente, é investir na educação permanente do profissional de saúde, o qual valorize a vida humana e exprima a indignação diante do sofrimento da população. Lembra que "a vida humana está cada vez mais desvalorizada” (Campos, 2006b, p.138). Lem-

14 Nelson Santos (2008, p.3) informa que em 2006 foram realizados 2,3 bilhões de procedimentos ambulatoriais, 300 milhões de consultas médicas, 11,5 milhões de internações, 360 milhões de exames laboratoriais, 2 milhões de partos, 23 milhões de ações de vigilância sanitária, 150 milhões de vacinas, 15 mil transplantes, 215 mil cirurgias cardíacas, 9 milhões de seções de radioquimioterapia e o controle mais avançado da Aids no terceiro mundo. 
bra ainda que a evolução científica e técnica dos serviços de saúde não estão sendo acompanhadas por um avanço correspondente na qualidade do contato humano.

O SUS viveu muitos avanços, reflete Conh (1995), mas apresenta sinais de esgotamento, porque vive um momento de intensos interesses contraditórios. A autora defende que o SUS não falhou como política, mas está sob constante ataque de forças que atuam para reduzir e fragmentar políticas públicas e programas de governo, voltados cada vez mais para a seletividade e a redução de recursos financeiros, lembrando que o subfinanciamento da área da saúde serve para favorecer a política econômica neoliberal e o setor de planos e seguros privados de saúde.

Os limites são expressivos, entretanto, a mesma autora aponta os desafios para o fortalecimento do SUS, o que passa, principalmente, pela importância de voltar a debater a questão da saúde nesse momento em que as atenções estão todas voltadas para a política econômica. Existe a necessidade da mobilização social, da percepção do cidadão quanto a seus direitos são fundamentais para o fortalecimento do SUS, uma vez que ainda não existe consenso de que a saúde é dever do Estado e direito de todos. A educação, como dizia Freire (1978), é o instrumento para ajudar na própria libertação, na transformação dessa condição de anulação, historicamente arquitetada e vivida pela sociedade brasileira diante da desconstrução do direito universal à saúde. 



\section{2 \\ As IDEIAS DOS TRABALHADORES A RESPEITO DO SUS}

\section{A construção do SUS}

O SUS? Sem dúvida, é um grande avanço em termos de saúde pública. Ele foi conquistado com trabalho, com luta, com movimentos, com mobilização social. Porque até então a situação de satisfação, de bem-estar da população não estava correspondendo às expectativas das pessoas com essa movimentação. $\mathrm{O}$ que aconteceu? As pessoas conseguiram se organizar e montar um padrão ideal do que seria o bem-estar, então surgiu o SUS. [...] Ele está bastante avançado em certos aspectos, como de instrumentação, de equipamentos, tecnologias, mas por outro lado, fica muito a desejar. Por exemplo, com relação ao atendimento integral, à humanização do atendimento, a questão dos relacionamentos. (S1)

Eu acredito no Sistema Único de Saúde. Acho que é um Sistema muito bacana, não acho que foi construído assim de uma hora para outra, não foi uma coisa que veio do nada, foi sendo construído com as Conferências, aquele processo lá atrás, das primeiras Conferências Nacionais de Saúde. Aquele processo todo que já vinha, de uma forma, com a participação da própria população, e hoje está mais forte com essas mudanças, com esse processo de saúde. Eu até acho que o que veio com o SUS que foi legal é essa nova maneira de olhar a saúde. Antes a gente tinha aquela saúde curativa, de estancar o que estava errado. Acho que com essas Conferências, com esse debate, veio esse novo modo de olhar a saúde como algo de qualidade também, de mudar o olhar pra saúde. E acho que, com isso, o SUS foi construindo, ao longo do tempo, um Sistema com uma filosofia mais preventiva e menos curativa [...]. Hoje eu acho que está legal. Tem falhas? Sim. Porque nosso País ainda é um país que tem corrupção, tem muito desvio; então isso faz com que a gente se torne mais pobre no Sistema de Saúde, 
tenha menos recursos, pague mal o trabalhador de saúde. Hoje eu acho que um dos problemas do Sistema de Saúde é que o profissional, o trabalhador do SUS, não é muito valorizado pelo próprio governo, acho que pelas próprias instâncias, vamos dizer governamentais, não é muito valorizado. Já estão acontecendo algumas mudanças também, eu acho que isso é bacana. (S2)

O SUS? Então, é o que eu te falei: a gente fica um pouco frustrada porque realmente é, [...], tem a ideia do SUS realmente muito boa, eu gosto, eu acredito no SUS. Mas eles (gestão, administração) nem conseguem botar realmente na prática tudo que eles querem. (S3)

É uma política maravilhosa, não é? Não sei, eu sou suspeita porque, eu acho assim, o SUS é benfeito. E quando vai pra prática, deixa a desejar, infelizmente. Não conseguiu atingir todo mundo. Então, o que eles colocam nos princípios do SUS, saúde pra todos. Mas é pra todos mesmo? Porque falta muita coisa. [...] Porque quando ele (Estado) coloca que o SUS tem a equidade, que é igual pra todo mundo, mas depois ele fala da integralidade, da universalidade? Então, você dá mais pra quem tem menos, a equidade, isso não acontece. [...] Mas quando ele fala da igualdade e depois ele fala em equidade, eu acho que ele tá divergindo nas ideias. [...] Tudo é discutido, tão querendo melhorar não sei o quê, mais aí, a hora que vai discutir a questão da vaga, uma vaga pra (a cidade), a gente não consegue. Tem uma... uma especialidade no HC de Ribeirão, é uma no ano, a neurocirurgia. [...]. É, uma no ano. É um horror, uma vergonha. [...] Que acesso é esse? Não consegue acesso... (S4)

Observa-se que, para os sujeitos entrevistados, há uma ênfase na importância do direito universal e integral à saúde para a sociedade brasileira. Neste capítulo, destaca-se o processo de construção do Sistema Único de Saúde (SUS), seus princípios e diretrizes organizacionais e seu funcionamento. Procurou-se explorar tanto as ideias dos trabalhadores da saúde a respeito do SUS quanto os sentimentos e conceitos relacionados ao trabalho na saúde e as opiniões e sugestões relacionadas a essa política pública de saúde.

As falas expressam os avanços com a implementação do SUS no País como uma política pública do Estado, referindo à universalidade de acesso, à integralidade da atenção, à participação da sociedade na gestão da saúde e à equidade para reduzir as desigualdades existentes no acesso à saúde. Há o reconhecimento dos trabalhadores da saúde de que o SUS é uma conquista da sociedade brasileira, e que a construção dessa política pública é resultado do movimento da Reforma Sanitária brasileira. Esse processo de mobiliza- 
ção e participação em torno do direito universal à saúde teve espaço nas Conferências de Saúde para o debate de ideias e propostas para o reconhecimento da saúde como um direito universal e integral.

No entanto, os sujeitos mostram os limites para implementação do modelo de atenção proposto, de promoção da saúde, associados às dificuldades enfrentadas na descentralização das ações e serviços de saúde para os municípios, bem como o acesso da população a serviços especializados, equipamentos e tecnologias. Isto leva a pensar no porquê de não estar dando certo. Assim, importa destacar que a luta pela transformação do sistema de saúde esteve vinculada também à busca pela transformação da sociedade e teve como marco o movimento de Reforma Sanitária brasileira, o qual se articulou a outros movimentos populares, intelectuais, políticos, científicos e culturais.

Resumidamente, a discussão acerca da democratização da gestão saúde, do acompanhamento e fiscalização de seus gastos, da universalização do direito à saúde, da atenção integral e descentralizada, entre outras questões, repercutiu também no pensar fazer dos serviços da área, como, por exemplo, em ações inusitadas sob o viés da educação popular. O conceito de educação popular, defendido por Paulo Freire em sua ampla bibliografia como um modo participativo de aprendizagem, rompe com a tradição educacional ocupada apenas com uma minoria social e confere à educação um conteúdo social, e não individualista, e uma dimensão ativamente política. Sua proposta é trabalhar pedagogicamente com o homem e os grupos (Bertani et al., 2008).

O movimento da Reforma Sanitária ampliou o leque das forças sociais que confluíram para novas práticas e conhecimentos em saúde, legitimando o direto (universal) à saúde. As ações de educação em saúde, apesar de não se tratar de uma diretriz nacional, constituíram-se em algumas experiências sobre a origem das doenças, resultando na proposta da metodologia de organização da comunidade como a resposta mais coerente na busca de solução dos problemas. E, como forma de responder às insatisfações da população e também baratear os custos dos serviços de saúde, foram implementadas ações de medicina comunitária.

A título de exemplo, foi estabelecida a aproximação da assistência médica aos mais pobres, dando início à descentralização dos serviços de atenção primária nos bairros da cidade por meio dos postos de saúde. Vasconcelos (1997, p.18) analisa que: 
O modelo de Medicina Comunitária, na medida em que pregava a utilização de técnicas simplificadas, de baixo custo e com a participação da população, era bem mais barata. Além disso, a valorização de ações preventivas e de alcance coletivo, ao invés das ações unicamente individuais da medicina curativa, aumentava a sua eficiência.

A educação popular favoreceu o desenvolvimento de novas práticas educativas em várias áreas, inclusive na saúde, como apresentam Lourenço \& Bertani (2003). Dessa forma, cabe elucidar alguns pontos importantes para a compreensão do papel da pedagogia como "ato amoroso", defendida por Paulo Freire (Boff, 1989, p.4).

Boff (1989) explica que a história não pode ser feita de individualidades, e seria contraditório depositar em Paulo Freire toda a criação do método de educação de proposta libertadora dos oprimidos. Mas, nesse sentido, Paulo Freire é precursor, intérprete, revelador e defensor de um processo de educação que visa, essencialmente, ao rompimento com a opressão. A partir da dimensão social e política, defende e dissemina o processo de educação como "ato amoroso". O "ato" corresponde à ação prática e à libertação, e "amoroso" é a postura de respeito, confiança e diálogo: juntos, ressignificam a educação como um processo solidário e de transformação, proporcionando libertação. Rompe-se, assim, com a atitude passiva e reprodutora do status quo presente na educação formal e tradicional. Nesse processo, educador e educando são sujeitos construtores da prática educativa-crítica, ou, nas palavras de Freire (2006, p.23), "[...] quem ensina aprende ao ensinar, e quem aprende ensina ao aprender”.

Segundo Manfredi (1978), a educação popular desenvolvida por Paulo Freire pode ser dividida em dois períodos: o primeiro, que compreende os anos de 1959-1965 e que teve como preocupação central a participação do povo no processo de desenvolvimento econômico, político e social; e aquele que se inicia a partir de 1964 cuja opressão marca a vida social e o período político. Nessa época, Freire vivia no exterior, e reformulou sua concepção de educação e "expressou as linhas mestras de uma pedagogia para a libertação” (Manfredi, 1978, p.68). Em um primeiro momento, a pedagogia de Paulo Freire esteve voltada para a alfabetização como possibilitadora da participação, ou seja, a educação elaborada e defendida por Freire é aquela que visa à "participação do povo”, e, como Manfredi (1978, p.68) esclarece, “[...] 
o caráter dessa participação deveria ser ativo, denotando sempre uma perspectiva de criticidade".

Timidamente, a nova visão de educação ganha destaque e passa a ter um papel substancial no processo de desvendamento dos determinantes históricos culturais e de democratização, mas alicerçada na "visão essencialista", que supervaloriza o papel do homem na sociedade e na história, que apesar de reconhecer os determinantes econômicos e políticos, sublinha a uma concepção idealista da história "[...] à medida que ressalta o papel do homem enquanto ser 'consciente' e 'criador', que desempenha sempre um papel ativo nas transformações sociais" (Manfredi, 1978, p.75, destaque do autor).

Manfredi (1978, p.91, destaque do autor) situa que a partir da obra $\mathrm{Pe}$ dagogia do Oprimido, a educação tradicional é vista como instrumento de controle e dominação, portanto, uma educação que não atende aos interesses dos oprimidos.

A situação de opressão não se manifesta, pois, como resultante de contradições inerentes a tipos estruturais historicamente encadeados e definidos, mas manifesta-se em toda e qualquer sociedade onde predomine uma situação de "injustiça", "opressão" e "violência", nas relações assimétricas entre dois polos, que o autor denomina genericamente de "opressores" e "oprimidos".

A "libertação" da condição opressora só tem condições de efetivar-se à medida que os indivíduos se reconhecem como "oprimidos". Apesar de não esclarecer e situar os termos "opressores" e "oprimidos" como estrutura social, Freire adota a perspectiva da educação como mola propulsora para a transformação social, defendendo que as pessoas modificam suas representações (imagens, conceitos etc.) e assim ganham elementos para transformar a realidade. A educação seria, com certeza, instrumento para a libertação.

Esclarece-se, aqui, que a apreensão do conceito de educação acontece pelo que está definido na Lei de Diretrizes e Bases (LDB), em que "[...] compreende o conjunto de processos formativos que acontecem na família, no trabalho, nos movimentos sociais" (Arroyo, 2002, p.134). O princípio fundamental da educação é a humanização, a compreensão do processo de formação do homem a partir de sua vivência, das relações culturais e sociais. Em continuidade a essa conceituação, compreende-se que a desumanização 
que ocorre na saúde decorre do tratamento que desconsidera a relação da doença com as injustiças e exclusão social.

Ao analisar a relação entre educação e saúde, recorre-se também a Arroyo (2002, p.135), que ao discutir o papel da escola, aproxima-se do pensamento marxista para falar da materialidade, das condições concretas da vivência humana que roubam as possibilidades do homem em se tornar efetivamente ser cidadão. Não se trata apenas de incluir o usuário nas unidades de saúde, mas de tornar possível a construção dos sujeitos sociais. A educação é, portanto, um projeto social que não se restringe aos limites da escola, e a função do educador é "recuperar a humanidade que foi roubada".

A necessidade de uma teoria pedagógica, para Arroyo (2002), é, atualmente, tão importante quanto foi nos anos 1940, uma vez que há muito mais excluídos agora do que no final dos anos 1960, referindo-se ao aumento da pobreza e das injustiças sociais. Pereira (2006, p.110) diz que nos anos recentes, o "número de pessoas em condições de indigência e pobreza pode ser expressa pela cifra de 50 milhões". O autor relata ainda que, apesar dos mais de 25 séculos de Paideia, ${ }^{1}$ o texto Pedagogia do Oprimido a mantém viva ao colocar como um dos paradigmas a interrogação de como o homem constitui-se humano. "E isto é o cerne da teoria pedagógica: como o ser humano se constitui um problema para si mesmo" (Pereira, 2000, p.131). O autor explica que esse pensamento, apesar de interrompido com o cientificismo do século anterior, é recuperado pela retomada das ideias de Paulo Freire, para o qual educar é humanizar distanciando-se da competitividade para aproximar-se da busca da compreensão dos processos de humanização.

O processo de constituir-nos como humanos é um processo histórico, um processo lento, cheio de contradições. Entender a historicidade conflitiva e tensa do constitutivo humano faz parte da teoria pedagógica e está muito presente esta dimensão na pedagogia popular, na educação popular (Arroyo, 2002, p.132).

Outra questão abordada é que, além da educação popular ser indicada a partir da construção do humano enquanto ser histórico, também considera que esse processo constitui-se no coletivo, ou seja, não é um ato que se faz no

1 A Paideia surge com a nova experiência da República. A Paideia é a arte de nos constituirmos humanos dentro de uma própria lógica e dentro de um processo social, político, cultural, concreto (Arroyo, 2002, p.132). 
individual, mas uma relação com os conhecimentos adquiridos-construídos entre gerações e relações sociais. A educação, então, alicerça-se no diálogo, nas relações sociais e na cultura. "Para Freire, a educação popular, como todo ato educativo, tem raízes na cultura ou nunca será educativo. Enraízase no processo de educação popular, porque o ser humano está calcado na cultura" (Arroyo, 2002, p.133). Portanto, explica-se que a educação popular não é aquela que o educador leva os seus conhecimentos até os "oprimidos", e faz o entendimento da temática recorrendo mais uma vez às palavras de Arroyo (2002, p.136):

a educação popular é a compreensão dos processos educativos que os próprios oprimidos, que os próprios desumanizados executam para se tornar mais humanos, conscientes de sua situação; é a pedagogia deles, de se entenderem como sujeitos pedagógicos e aí não cabem nas duas mãos os sem terra, os sem trabalho, as feministas. O fazer pedagógico é um eterno refazer, porque a tarefa de formar humanos será um eterno refazer sempre.

Retomando as possíveis influências da educação popular na área da saúde, verifica-se que, a partir dos anos 1960, esta encontra eco no movimento de cultura popular, visto que principia o envolvimento de grandes educadores, com sujeitos anônimos e antagônicos. Dentre eles, o autor ressalta pastores evangélicos, líderes espíritas, maçons, militantes socialistas, intelectuais e livres-pensadores.

Nesse processo, também os profissionais da saúde insatisfeitos com as práticas mercantilizadas e rotinizadas dos serviços de saúde, nas palavras de Vasconcelos (1997, p.146), dão início a novas ações, “[...] construídas a partir do diálogo entre o saber popular e o saber acadêmico”. A igreja católica, que de certa forma estava "preservada" da perseguição e repressão política, apoia as iniciativas de educação popular. Esse respaldo do templo cristão possibilitou à área de saúde várias experiências de controle de serviços prestados por organizações populares.

Contudo, a unidade de saúde que serviria para aproximar a saúde das pessoas - o que viria a beneficiar, principalmente, àquelas economicamente menos favorecidas, moradoras de regiões periféricas, - ao baratear o sistema, acabou, infelizmente, tornando-se mecanismo de politicagem. Diante da escassez de recursos para o funcionamento dos postos de saúde, estabeleceu-se uma relação clientelista, não se concretizando de forma efetiva a edu- 
cação popular na saúde. Os profissionais descontentes com a medicina especializada, tecnificada e comercializada começam a organizar-se em associações e sindicatos, além de buscarem junto às classes populares novas práticas pela criação de uma medicina mais apropriada aos interesses da maioria empobrecida da sociedade brasileira.

As poucas experiências de educação popular na saúde representam alternativas de enfrentamento ao descaso e às utilizações eleitoreiras pelo governo dos serviços de saúde. Essas práticas defendem que a medicina preventiva pode não somente curar, mas também construir novos comportamentos capazes de evitar doenças e de promover a qualidade de vida e, sobretudo, a mudança de enfoque do saber médico como o absoluto.

Nesse sentido, pode-se evidenciar a abordagem da educação em saúde na compreensão das origens das dificuldades de se introduzir práticas participativas às suas soluções. Aproxima-se da pedagogia freiriana ao admitir que o saber científico de base biologista não é único e, tampouco, absoluto, e que a educação em saúde caracteriza-se por uma constante troca de saberes entre as conquistas do conhecimento científico e a sabedoria popular acumulada.

Ao sair do espaço delimitado da prática de saúde, visualiza-se que a mudança de paradigma na saúde foi a tese defendida pelo movimento sanitário brasileiro, traduzida, nas palavras de Paim (1997, p.12), como "paradigma sanitário". A princípio, expressava a necessidade de reforma do modelo de saúde vigente, limitado ao processo diagnóstico-resposta. Criticava a concepção restrita de saúde, bem como o asfixiante condicionamento entre organização social dos serviços de saúde e da prática médica.

Estrategicamente, além de envolver outros organismos sociais na discussão sobre saúde, o movimento sanitário institucionaliza-se com a criação do Centro Brasileiro de Estudos de Saúde (Cebes): “[...] alcançando assim constituir-se em um verdadeiro partido sanitário, que foi capaz de organizar as diferentes visões críticas do sistema de saúde, definindo um projeto comum e estratégias e táticas de ação coletiva" (Fleury, 1997, p.26). Enfim, a década de 1980 é assinalada por vários movimentos sociais e também pelo retorno do exílio de Paulo Freire ao Brasil, o que reacende o debate da educação popular, que passa a ser pensada como parte da ação política e, assim, contribuindo para o movimento do direito à saúde, o que está evidenciado nas falas dos sujeitos $\mathrm{S} 1$ e S2. 
Na história das Conferências brasileiras até a 8 a Conferência Nacional de Saúde (CNS, 1986) não houve ênfase na participação dos usuários nas ações da saúde pública, no sentido de fortalecimento do poder local, de construção da solidariedade social e da participação cidadã na saúde. A mudança na formatação das Conferências e da própria condução da política de saúde pública foi permeada pelos vários movimentos sociais e inclusive contou com o postulado dos movimentos internacionais, que, no Brasil, fortaleceu o movimento da Reforma Sanitária.

No Brasil, a ruptura com o regime militar foi lenta e gradual. A anistia, em 1979, possibilitou a remissão aos torturadores e concedeu direitos políticos e civis aos considerados inimigos da nação. Faleiros (2000) reflete que a conjuntura econômica demarcada pela inflação e pela dívida pública acentuada fez com que a sociedade emergisse com força inusitada da repressão na disputa por seus interesses na Assembleia Nacional Constituinte, com manifestações públicas, formação de comitês, articulação de organismos, estruturação de abaixo-assinados e organização de vários grupos - mulheres, índios e negros, além de empresários, setores específicos de empresas e ruralistas.

A acentuada desigualdade econômica ganha dimensão social e política com propostas para adequar os serviços públicos à realidade da população empobrecida, o que favorece o surgimento de movimentos sociais contra a ditadura e o autoritarismo associados à defesa da democracia e da liberdade política e civil. É no processo de abertura e de democratização política que o movimento para a Reforma Sanitária brasileira toma configuração, primeiramente por uma parcela da intelectualidade e profissionais dos serviços públicos de saúde e, posteriormente, incorporam-se outros segmentos da sociedade, como sindicatos, partidos políticos, movimentos populares de saúde e demais movimentos organizados da sociedade civil.

A ideia central do movimento da Reforma Sanitária, que transcorre historicamente nos anos 1970 e 1980, é a organização do sistema de saúde propondo uma reforma total nesse campo. Cohn (1991, p.22) ressalta que são décadas "[...] inesgotáveis em estudos diagnósticos, analíticos e propositivos sobre as questões da saúde no Brasil”. O movimento sanitário não significou de imediato a ruptura com o modelo tradicional de saúde, como refletem Lourenço \& Bertani (2006), o qual está atrelado ao utilitarismo político, muitas vezes aliado à classe dominante, que historicamente utilizou o poder 
e estabeleceu políticas públicas como benemerência. Assim, a política aparece ligada à pessoa governamental detentora de poder público travestido na figura de um sujeito "bonzinho" que pratica uma "boa ação". Este manipula a política pública em benefício próprio, o que provoca, entre outros males, um distanciamento entre o acesso e o direito, estreitando essa relação ao patamar do favor e subalternidade.

Entretanto, apesar de não ter havido, de imediato, o rompimento desse modelo de fazer saúde, visualizou-se a possibilidade do envolvimento da sociedade no debate sobre a política de saúde, levando, consequentemente, o Estado a adotar medidas favoráveis para a construção do Sistema Único de Saúde (SUS). Essas medidas não foram incorporadas na totalidade conforme as propostas do movimento, mas também não foram ignoradas por completo. "Porque, até então, a situação de satisfação, de bem-estar da população não estava correspondendo às expectativas das pessoas com essa movimentação" (S1), como analisa o trabalhador da saúde.

Ao buscar os principais acontecimentos que nortearam a $8^{\underline{a}}$ Conferência Nacional de Saúde (CNS, 1986) e a implementação do SUS, verifica-se que o período da década de 1980, além de se configurar pelos tateantes avanços no campo democrático brasileiro (Ghon, 2003), foi palco também de forte crise econômica e política. Na saúde, as discussões pautavam-se, sobretudo, no deficiente sistema previdenciário, como registram os documentos da 7a Conferência Nacional de Saúde. A partir daí, há possibilidade de incorporação de alguns técnicos do movimento sanitário no interior do Instituto Nacional de Previdência Social (INPS), o que acaba sendo útil para as reivindicações do movimento de Reforma Sanitária, como Lourenço (2004) evidenciou.

Segundo Carvalho (1995, p.23), na busca de soluções, o governo convida alguns técnicos ativistas do movimento sanitário para incorporar a administração pública da saúde. No interior do INPS, torna-se favorecido "[...] o debate intrainstitucional, alargando os marcos para a busca de alternativas e ampliando os espaços de participação dos técnicos não comprometidos com o modelo dominante".

Como pode-se perceber, os programas que antecederam o SUS, resultantes do movimento sanitário, iniciaram, mesmo que timidamente, a participação da comunidade e a descentralização estabelecendo nas três esferas de governo a competência para cuidar da saúde de sua população, alicerçando as bases da saúde como direito e cidadania a partir do nível local. O movi- 
mento representado pelo Cebes teve importante papel no I Simpósio Nacional de Política de Saúde, realizado em 1979 pela Comissão de Saúde da Câmara dos Deputados, o qual declarou as bases para a reorientação do Sistema de Saúde: democratização da sociedade, universalização do direito, descentralização e participação.

Como produto desse momento, o Ministério da Saúde e da Previdência elabora o Programa Nacional de Serviços Básicos de Saúde (Prev-Saúde), que pretendia estender a cobertura para toda a população. Segundo Teixeira e Mendonça (1995), o programa implicou a descentralização, a hierarquização e a regionalização, dando ênfase aos serviços de atenção básica à saúde. Por exemplo, na década de 1980, surgiram vários projetos como o Prev-Saúde que pretendia estender a cobertura para toda a população, com ênfase nos serviços básicos de saúde. Em seguida, apareceu o Conselho Nacional de Administração da Saúde Previdenciária (Conasp), que elaborou um plano retomando as ideias do Prev-Saúde para uma descentralização e utilização prioritária dos serviços públicos para atender à demanda (Lourenço, 2004).

A implementação das Ações Integradas de Saúde (AIS), em 1984, que esperava integrar os serviços que atendiam à população de uma mesma região, acontece no final do regime militar, e, diante do avanço do processo de redemocratização do País, o regime militar, já em um período de "distensão política", implementou eleições para cargos do Poder Executivo, permitindo a abertura gradativa da liberdade de imprensa, de associação e organização partidária. Os programas governamentais favoreceram a participação da população por meio da criação de comissões ou conselhos que deveriam ter entre seus componentes representantes da sociedade civil.

Observa-se que todos os planos eram parecidos e havia uma ideia de integração da saúde pública com a assistência médica individual, por isso foram combatidos pelos grupos médicos privados e pela própria burocracia do Instituto Nacional de Assistência Médica e Previdência Social (Inamps). Entretanto, as AIS possibilitaram as primeiras medidas de descentralização da saúde pública brasileira, que, apesar das limitações, apontaram para a formação de colegiados e comissões interinstitucionais nos níveis: federal, estadual, regional e municipal. E, no âmbito local, previam a participação de entidades comunitárias e sindicais, no intuito de garantir a melhor aplicação dos recursos. 
Por outro lado, Cortez (2003, p.25), analisa que as AIS representaram, dentre outras intenções, uma "[...] estratégia do regime militar para reduzir os custos do sistema previdenciário, os quais haviam crescido durante os anos 1970". Esse Programa de Saúde foi aprimorado com o Sistema Unificado e Descentralizado de Saúde (Suds), em 1986, o qual manteve a ênfase na necessidade de formação de colegiados e na municipalização dos serviços de saúde pública, e com ele inicia o processo de descentralização e municipalização dos serviços de saúde pública.

É com o Suds que se inicia o processo de municipalização da saúde. O governo municipal passa a ser o gestor dos serviços pertencentes a seu território, sendo que aqueles considerados de alta complexidade são organizados de modo regional, no sistema de referência para mais de um município. O repasse financeiro para o planejamento e execução dos serviços tem como quesito a participação da sociedade civil e organizada por meio dos conselhos e conferências de saúde, reafirmando a proposta do movimento sanitário.

Notas-se que, nos anos 1980, ao mesmo tempo em que a sociedade brasileira vivenciou um processo de transição democrática com a mobilização da sociedade civil contra o Estado, experimentou-se uma profunda e prolongada crise econômica, cujos efeitos persistem até os dias atuais. A conjuntura da saúde retratou as contradições do País com doenças infectocontagiosas próprias do subdesenvolvimento e crônico-degenerativas próprias das sociedades industrializadas. Esse contexto favoreceu o surgimento do movimento para a Reforma Sanitária brasileira, quando a questão da saúde passa a ser discutida pela população, rompendo o costume, até então predominante, de apenas o Estado e as classes dominantes tomarem iniciativas na área da saúde.

As proposições do movimento da Reforma Sanitária brasileira, na análise de Bravo (1996, p.4), estavam dirigidas basicamente "à construção de uma nova política de saúde efetivamente democrática [...]”, apresentando a cidadania como um componente central, e a descentralização do processo decisório como caminho para a democratização do poder local por meio de novos mecanismos de gestão. Esse movimento é significativo e "consiste na organização dos setores progressistas de profissionais de saúde pública, que colocou em debate a relação da prática em saúde com a estrutura de classes" (Bravo, 2004, p.32), e busca o fortalecimento do setor público em oposição.

Para Cohn (1997, p.233), o movimento da Reforma Sanitária, 
calcado na experiência italiana, e sob a liderança não pública do partido Comunista Brasileiro, congrega os setores de esquerda e os setores progressistas da área da saúde na formulação de propostas para sua reorganização institucional no país e na produção de conhecimento que desse suporte a elas. À militância política pela conquista da saúde como um direito e um dever do Estado associa-se o que denominei um "saber militante", que caracteriza a produção da Medicina social brasileira no período, e que fundamenta as práticas políticas de então.

Com essa perspectiva, o ideário da Reforma Sanitária brasileira consiste na proposta de um sistema de saúde universal, público e descentralizado, sob a responsabilidade do Estado. A universalidade da atenção à saúde é o enfoque para romper com a histórica separação entre assistência médica individual e ações coletivas de saúde, e a descentralização do sistema de saúde é a estratégia nesse processo para a racionalização de custos e a "valorização da criação de novos espaços institucionais de participação, com poder deliberativo dos segmentos organizados da sociedade, constituindo-se assim uma estratégia de ampliar, no espectro social, as oportunidades de acesso ao poder”, reafirma Cohn (1997, p.233), para efetivar a participação da sociedade civil na gestão da saúde.

Há, nesse contexto, a formulação de propostas para o setor, que procura viabilizar a construção da saúde como um direito da população brasileira e um dever do Estado, apresentando a cidadania como um componente central. As reivindicações desses sujeitos sociais exigiam respostas do Estado, relacionadas às questões sociais emergentes no País - desemprego, saúde restrita a alguns, falta de saneamento básico, habitação, infraestrutura inadequada, problemas resultantes do processo acelerado da industrialização, urbanização, imigração, empobrecimento, desemprego, entre outros problemas. Sintetizado por um dos sujeitos entrevistados, essa ação se deu: "As pessoas conseguiram se organizar e montar um padrão ideal do que seria o bem-estar, então surgiu o SUS” (S1).

Nesse percurso, a realização da 8a Conferência Nacional de Saúde (CNS, 1986), realizada em 1986, marca uma nova era para a saúde pública no Brasil. Com o tema "Saúde como Direito de Todos e Dever do Estado" e expressiva participação popular de 4,5 mil pessoas, sendo mil delegados representantes de diversos setores da sociedade civil, delibera propostas para pressionar a Assembleia Nacional Constituinte e inserir o projeto de saúde 
defendido e aprovado pelos movimentos sociais na Constituição Federal brasileira (Bravo, 1996).

Destaca-se que a representatividade de delegados na 8a CNS (1986) obedeceu aos seguintes critérios (Brasil, 2004d, p.9):

$50 \%$ representantes das instituições (públicas, estatais, educacionais, de pesquisas, etc.) e os outros $50 \%$ da sociedade civil (entidades, associações e órgãos de representação de produtores privados de serviços de saúde, entidades de diversas categorias de profissionais do setor saúde, sindicatos, associações de trabalhadores urbanos e rurais, associações de moradores, entidades comunitárias e civis, partidos políticos).

A organização da população apontada pelos sujeitos entrevistados mostra que esse passo foi decisivo para o processo de concretização de direito à saúde e de atribuições e responsabilidades entre os níveis de governo federal, estadual e municipal. Foi por meio da organização dos movimentos sociais e de saúde, com caravanas, mobilizações e abaixo-assinados, e da participação na Assembleia Nacional Constituinte que a sociedade brasileira lutou para que fosse aprovada a Reforma Sanitária no País e defendeu que a Constituição Federal de 1988 instituísse o Sistema Único de Saúde, o SUS.

Considerada um marco na história da saúde pública brasileira, a 8 $8^{a} \mathrm{CNS}$ consagra as ideias preconizadas nesse movimento, assinalando um processo democrático quando sistematiza e formaliza como proposta política as principais teses discutidas para a Reforma Sanitária brasileira, envolvendo o conceito abrangente de saúde. Foi nessa Conferência que as diretrizes e os princípios do SUS foram formulados e organizados como uma política pública do Estado. Sua importância no processo democrático e participativo é demonstrada pelos próprios atores sociais que participaram desse momento significativo na história da saúde pública brasileira. ${ }^{2}$

É desse contexto que emergem significativas mudanças, como por exemplo, o conceito saúde, entendido até então como a ausência de doenças e bem-

2 A construção do SUS: história da reforma sanitária e do processo participativo (Brasil, 2006a). O livro organizado por Faleiros resgata e analisa a dinâmica do processo da Reforma Sanitária, evidenciando a trajetória do movimento social e a democracia participativa na construção do SUS, as quais contribuíram na construção do "arcabouço jurídico do SUS", da Constituição Federal de 1988 e as diversas regulamentações pós-constituição. 
estar físico e mental, é substituído por outro, ampliado em seus diversos fatores determinantes e condicionantes das condições de vida da população com a intenção de alterar a situação de desigualdade na assistência à saúde.

Portanto, "esse novo modo de olhar a saúde" (S2) como algo de qualidade, resultou que a saúde foi definida, na Constituição Federal, como elemento da Seguridade Social (Brasil, 1988, p.103), a qual “[...] compreende um conjunto integrado de ações de iniciativa dos Poderes Públicos e da sociedade, destinado a assegurar os direitos relativos à saúde, à previdência e à assistência social", com objetivos de universalidade, uniformidade, equidade, descentralização, entre outros. Esses objetivos levam Bravo (1996, p.9) a considerar que a Seguridade Social é

a corporificação legal e institucional de um acordo societário que se construiu como base de nosso processo de transição à democracia. Em outras sociedades latino-americanas, com uma experiência democrática muito mais densa, a transição teve o caráter de reconstrução da institucionalidade democrática. No caso brasileiro, dada a escassa e frágil experiência democrática anterior, a transição constituiu-se no momento de criação dos instrumentos e processos democráticos. Nunca a noção de cidadania e de direitos sociais havia sido tão discutida e vivenciada em nossa sociedade.

O direito à saúde está legalizado na Constituição Federal de 1988, em seu Artigo 196, “[...] e garantido mediante políticas sociais e econômicas que visem à redução do risco de doença e de outros agravos e ao acesso universal e igualitário às ações e serviços para sua promoção, proteção e recuperação" (Brasil, 1988, p.32). É quando o SUS apresenta como grande avanço o princípio de universalização do atendimento, tornando-o público e gratuito e uma das conquistas mais significativas da sociedade brasileira.

A história da saúde é, deste modo, marcada por mudanças significativas, passando a ser uma questão social reconhecida como direito do povo e dever do Estado, especialmente por ser um problema social que se tornou uma questão política, tornando-se uma política pública. No plano jurídico, a promulgação da Constituição e a criação do SUS representam garantias importantes de direitos sociais para os cidadãos. O SUS é construído ativamente pela sociedade civil e torna-se um direito reconhecido.

Ao tornar-se pública, a questão da saúde no País cria abertura e espaço de luta pela democracia e conquista de cidadania no setor. As ações e servi- 
ços públicos de saúde são definidos como de relevância pública, devendo integrar uma rede regionalizada e hierarquizada e constituindo um Sistema Único, organizado de acordo com as seguintes diretrizes: "[...] descentralização, com direção única em cada esfera do governo; atendimento integral, com prioridade para as atividades preventivas, sem prejuízo dos serviços assistenciais; participação da comunidade" (Brasil, 1988, p.105).

De acordo com a Constituição Federal, o SUS tem como competência diversas atribuições voltadas para o controle, fiscalização, execução de ações de saúde, formação de recursos humanos, proteção do meio ambiente e do trabalho, entre outras. E como objetivos, identificar os fatores condicionantes e determinantes da saúde e formular políticas para erradicar as desigualdades no campo econômico e social os quais interferem na saúde. Esclarece que o financiamento do Sistema é feito com recursos do orçamento da Seguridade Social, da União, dos Estados, do Distrito Federal e dos municípios, além de outras fontes, significando recursos arrecadados por meio de impostos e contribuições sociais pagos pela população (Brasil, 1988).

A regulamentação do SUS estabelecida pelo conjunto das Lei Orgânica da Saúde (LOS) nº 8.080/90 e a no 8.142/90, para dar execução e disciplinar legalmente a proteção e a defesa da saúde, com diretrizes e limites que devem ser adotados pelo território nacional, esclarecendo o papel das três esferas de governo (Brasil, 1990a). Na LOS no 8.080/90, destacam-se os princípios organizativos e operacionais do Sistema de tal modo que indica a descentralização político-administrativa e enfatiza a municipalização dos serviços de saúde, com redistribuição de poder, de competências e de recursos, e afirma o novo conceito:

A saúde tem como fatores determinantes e condicionantes, entre outros, a alimentação, a moradia, o saneamento básico, o meio ambiente, o trabalho, a renda, a educação, o transporte, o lazer e o acesso aos bens e serviços essenciais; os níveis de saúde da população expressam a organização social e econômica do País.

Parágrafo único. Dizem respeito também à saúde as ações que, por força do disposto no artigo anterior, se destinam a garantir às pessoas e à coletividade condições de bem-estar físico, mental e social (Brasil, 1990a, p.20).

A saúde, compreendida, até então, como a ausência de doenças e bemestar físico e mental, passa a ter um conceito ampliado em seus diversos fa- 
tores determinantes e condicionantes das condições de vida da população, com a intenção de alterar a situação de desigualdade na assistência à saúde. A visão de saúde na concepção integral prevê que as ações devam ser desenvolvidas sobre o ambiente e os indivíduos, destinadas à proteção, promoção e recuperação da saúde, e voltadas para a erradicação das causas sociais que interferem na saúde.

Em sua composição, abrange as ideias de um novo modelo de saúde pública, as quais constituem os princípios e diretrizes estabelecidos na LOS $\mathrm{n}^{\circ}$ 8.080/90, os quais ressaltam a cidadania para universalidade de acesso aos serviços em todos os níveis de assistência; integralidade de assistência, entendida como conjunto articulado e contínuo das ações e serviços preventivos e curativos, individuais e coletivos; preservação da autonomia das pessoas; igualdade da assistência à saúde, sem preconceitos ou privilégios de qualquer espécie; direito à informação sobre a saúde; divulgação de informações quanto ao potencial dos serviços e a sua utilização pelo usuário.

A participação popular, garantida na LOS de n 8.142/90 por meio de Conselhos e Conferências nas três instâncias de governo (municipal, estadual e federal), define a maneira que a população irá acompanhar e fiscalizar as políticas de saúde. A ideia de controle social e de cogestão é inovadora e democrática (Brasil, 2004c, p.12):

estabelece uma nova relação entre o Estado e a Sociedade, de forma que as decisões do Estado sobre o que fazer na saúde terão que ser negociadas com os representantes da sociedade, uma vez que eles, é quem melhor conhecem a realidade de saúde das comunidades. Por isso ela é entendida como uma das formas mais avançadas de democracia. Mas, embora esteja prevista em Lei, a participação social é um processo, em permanente construção, que comporta avanços e recuos e, por isso, muitas vezes, depende de ampla mobilização da comunidade na defesa de seus direitos.

Importa lembrar, como fez um dos entrevistados, que "o SUS foi conquistado com trabalho, com luta, com movimentos, com mobilização social" (S1), portanto, o controle social autoriza a influência da população na gestão do SUS e possibilita as ações do Estado na direção dos interesses da coletividade. Previa-se a democratização das ações de saúde por meio da participação dos usuários nos conselhos e conferências. Não obstante, as conquistas institucionais aprovadas na Constituição, que contempla o ideário 
da Reforma Sanitária, não conseguiram romper com a lógica anterior, em que a base de financiamento do sistema de proteção social esteve sempre atrelada ao capital privado.

Para Cohn (1997, p.234), o sistema de Seguridade Social instituído - saúde, previdência e assistência social -, "ao mesmo tempo que universaliza os direitos sociais, segmenta os distintos setores da sociedade no acesso a benefícios e serviços". Ainda nesse pensamento, Cohn (1997, p.235) enfatiza que, ao mesmo tempo em que o setor privado se estruturou e capitalizou nas décadas de 1960 e 1970, atualmente pressiona e busca novos mercados de serviços prestados à Seguridade Social sem intervenção estatal. Conclui que o movimento sanitário brasileiro termina a década de 1980 " [... ] assistindo ao seu esgotamento - representado pela mudança institucional do setor - sem, no entanto, lograr reverter a lógica que vinha regendo as políticas de saúde de maneira a garantir a universalidade e a equidade da atenção à saúde num processo de crescente exclusão social”.

É esse contexto que vai interferir, de forma negativa, na implementação do SUS nos anos 1990. As mudanças profundas da economia brasileira, na década de 1980, provocadas pelo processo de "globalização" do mercado e pelo novo paradigma tecnológico de produção, levaram a um "desenvolvimento industrial com alto grau de transnacionalização” (Cohn, 1997, p.236). Em consequência, o País enfrenta a década de 1990 com o custo social profundo e com iniciativas de privatização do patrimônio estatal e de várias de suas responsabilidades. "Neste caso a contrapartida do capitalismo selvagem traduz-se numa privatização selvagem”, conclui Cohn (1997, p.236).

A ideologia do neoliberalismo, que informa as políticas econômicas e sociais nas últimas décadas, tem rejeitado a responsabilidade do Estado perante a nova questão social. Assim, contemporaneamente, as políticas sociais como mecanismos de regulação da questão social não desapareceram reestruturaram-se para responder aos desafios impostos pelas transformações da questão social. Só que essa reestruturação comprometeu um projeto de sociedade que tinha na igualdade a sua referência, o que exige, para Pereira (2000), determinação e preparo intelectual e político para lutar pela prevalência dos valores de uma sociedade livre e igualitária.

O que se observa é a mercantilização da vida e da saúde determinada pela conjuntura econômica, o poder do mercado fortalece cada vez mais a hegemonia do capital. Esse movimento de mercantilização repercute na saúde e 
confronta diretamente com as propostas do SUS e, do mesmo modo, contribuiu para a transformação dos espaços políticos em espaços de mercantilização: onde tudo tem preço e compra quem pode. Aproveitando as palavras de Demo (1994, p.13), “[...] o capitalismo representa uma das sociedades mais discriminatórias, e para tentar superá-lo existem formas democráticas que não exterminam o poder, mas tentam domesticá-lo".

A perspectiva é a de fortalecer as propostas nascidas no movimento da Reforma Sanitária brasileira e que constituem as ideias centrais da criação do SUS, especialmente porque concentram as necessidades e expectativas da sociedade em relação à saúde. Na ideia defendida por Gastão Campos (2007b), é na concepção ampliada de saúde, que considera as condições de vida e de trabalho e relaciona saúde aos fatores que a determinam - as condições materiais de vida-, que deve pautar a luta pelo sistema público de saúde.

Dessa maneira, a partir do SUS, tem-se a compreensão de saúde não mais enquadrada apenas nos limites da doença. Há o enfoque, sobretudo, dos determinantes sociais, embora no cotidiano ainda sobressaiam ações embutidas de antigos valores. Na realidade, observa-se que os serviços de atenção primária, mais próximos dos usuários e de sua realidade, deveriam enfocar a educação em saúde, contudo, acabam se restringindo à execução de tarefas dentro da lógica do capitalismo. Assim, apesar dos avanços postos pela mudança de paradigma da política de saúde, os atendimentos continuam sendo feitos dentro do modelo verticalizado tradicional, sem que haja qualquer manifestação de visão de mundo sócio-histórica.

Algumas características do antigo modelo de saúde pública desdobramse na dependência da dinâmica dos serviços técnico-administrativos e burocráticos institucionais, os quais tanto podem interrompê-los como perpetuálos. Reforça-se a importância do processo em que todo o trabalhador da saúde enquanto sujeito histórico tem um papel de destaque na conquista do espaço dentro dos vários serviços para a introdução de ações de educação em saúde e participação.

Assim, as atribuições estabelecidas, bem como as introduzidas na direção da responsabilidade sanitária de cada trabalhador da área, indicam que a atenção em saúde abrange a prevenção e a promoção da saúde, ocorrendo nas condições e processos de trabalho. A clareza e lucidez das respostas dadas pela instituição do SUS às demandas de saúde-doença remetem, necessariamente, às determinações da questão social e das transformações con- 
temporâneas, bem como ao papel do Estado e da sociedade na sua condução e gestão. Machado (2006), analisando esse assunto, destaca que a promoção da saúde se desenvolve por meio da práxis entre os serviços de saúde e a comunidade, porém não se trata de uma atuação restritiva, e sim de integração com outras áreas.

O que se tem observado é que, em lugar de ações voltadas a antecipar o prejuízo social provocado pelos determinantes desfavoráveis, estes são simplesmente constatados, sem que sobre eles resultem intervenções pertinentes. A formação e o desenvolvimento da consciência crítica dos trabalhadores da saúde são, pois, necessidades para mudança do modelo de atenção e efetivação dos princípios e diretrizes que sustentaram a construção do SUS: a integralidade das ações, a descentralização político-administrativa e o controle social. Aqui, a questão do acesso, tão evidenciada pelos sujeitos da pesquisa, demonstra os limites para efetivar a integralidade e garantir a equidade na atenção à saúde.

Os trabalhadores da saúde pontuaram também a questão financeira e o acesso no SUS como uma das maiores dificuldades encontradas para o desenvolvimento do trabalho:

Eu acho que poderia ser diferente é a questão financeira. Eu acho que o SUS, hoje ele ainda está meio subfinanciado, precisava ter um financiamento maior, investimento maior, $[\ldots]$ precisava de mais verba. Isso dificulta o engajamento com a equipe $[\ldots]$. . (S2)

O grande problema dos municípios pequenos é o acesso às especialidades e cirurgias, às especialidades de cardiologia, neuro, ortopedia, otorrino e a dependência que fica em relação ao município referência. Funciona a atenção básica e a equipe mínima. [...] Porque, vou dar um exemplo: oftalmo é um problema, a prefeitura é que paga por fora. Tá certo isso? [...] Mas, por exemplo, igual aqui pra nós, município pequeno: quando você fala da ressonância, não faz... do ecocardiograma... é uma luta pra fazer ecocardiograma. Porque isso o SUS prevê. Então aí, acho que atravanca um pouco na parte de referência, porque depende da microrregião, não depende só do município (S4).

Observa-se que os enfrentamentos desses problemas não são somente econômicos, mas também são culturais, políticos, sociais e educativos. Buscando soluções para questões tão complexas, encontram-se na reflexão de 
Gastão Campos (2006b) alguns caminhos possíveis para a consolidação do SUS. O autor reflete que há um desencantamento da população brasileira em relação ao SUS quanto à viabilidade de uma política social que é solidária e racional. Assim, qualquer movimento que faz melhoria não repercute, e a população não reconhece em razão das situações apresentadas nos serviços de saúde.

Esse desencantamento, para Gastão Campos (2006b), está relacionado à própria Reforma Sanitária, que está incompleta e, após vinte anos da criação do SUS, apresenta vários sintomas, sendo necessário repensar sua prática.

Essa questão de rever o princípio do SUS. Será que seria um caminho? Eu deixo interrogado. [...] Eu já pensei várias vezes: será que é esse o caminho mesmo? [...] É, quando fala que é pra todo mundo, tem que ser pra todo mundo. Existe muita cobrança do próprio usuário quando você fala que é pra todos. Nossa, há mais de vinte anos depois, a gente ouve: Ah, é pelo SUS? Pelo SUS não vira. Por que não vira? Então, tem que ser pra todos, tem sim, mas tem que ser revisto, porque se vocêt tem condições, você paga imposto. Então tem, assim, os dois lados da moeda. [...] É, é um sistema adequado, só que como ele não tem o financiamento, a gente fica tentando priorizar a população empobrecida, carente, a que mais precisa. $\mathrm{E}$ ao mesmo tempo as pessoas, o próprio usuário, o trabalhador não valoriza o SUS, que acha que ele é uma coisa pública, que ele não tem valor. [...] Não valoriza, é isso. Então, talvez precisasse ser revisto. Terá? Onde que tá o problema? Será que é lá em cima? Porque o Brasil, eu falo que é um país muito rico, pena que tem os desvios. Se não houvesse tanto desvio, a gente teria mais condições. Não só de saúde, mas de educação, na área social. Ainda fica a desejar, né? Melhorando essa parte social, a parte de financiamento, da formação. Mas eu acho que é trabalho de formiguinha, não é? (S4)

Gastão Campos (2006b) lembra que hoje, no mundo comandado pelo modelo neoliberal, um sistema de saúde com princípio universal está na contramão desse processo social. Desse modo, a recuperação da imagem da política pública de saúde exige dos atores sociais uma ação que estimule os movimentos sociais e as opiniões em defesa da vida, do bem-estar e da proteção social. A questão do financiamento do SUS, preocupação evidenciada pelos sujeitos da pesquisa, mostra que a falta de recursos financeiros compromete o desenvolvimento do trabalho na saúde em diversos aspectos. A busca por um financiamento compatível com as necessidades de saúde por parte das três esferas de governo é uma necessidade imediata. 
Ao analisar o funcionamento do SUS, Santos (2008, p.4) diz que os serviços de saúde sobrevivem ao modelo de gestão caracterizado por "drástico subfinanciamento público, fragmentação dos repasses federais, largo predomínio do pagamento de serviços por produção em regra com valores inferiores aos custos, descolamento dos hospitais do SUS das redes hierarquizadas/regionalizadas". O autor associa a baixa implementação dessas redes de atendimento com a precarização das relações de trabalho na prestação dos serviços e ausência de práticas de metas, desempenho e resultados. E ressalta ainda que, enquanto o País privilegiar o setor privado, nenhum recurso será suficiente, atualmente, o serviço privado sendo o principal, e o público, complementar.

Outro caminho apontado por Gastão Campos (2006b) é definir o modelo de atenção, uma questão crônica e desgastante, que fica no discurso entre a prevenção e a atenção curativa. A implementação do SUS, em termos de Estados e municípios, está muito heterogênea, apesar da atenção primária ser crescente. Há evolução do número de municípios com a estratégia Saúde da Família, mas a cobertura ainda é baixa, ou seja, a velocidade de implementação está aquém da necessidade da população. Não se esquecendo de que a cobertura da atenção primária deve atingir pelo menos $80 \%$ da população.

Nessa perspectiva, a questão da municipalização da saúde requer um modelo de gestão do trabalho mais flexível e racional, e esse é outro problema que precisa de solução no SUS. É preciso destacar a importância do trabalho bem-remunerado e que dê condições de vida digna ao trabalhador da saúde. Para Nelson Santos (2008), na implementação do SUS, as necessidades dos trabalhadores não foram contempladas, as relações de trabalho foram precarizadas, tornou-se comum a contratação verbal, o apadrinhamento, a terceirização, a inexistência de plano de carreira e de amparo legal.

A gestão do SUS transferiu aos municípios a responsabilidade pela contratação dos trabalhadores. Isso trouxe dificuldades para o sistema ser solidário e cooperativo, e para Gastão Campos (2006b), esse é um problema do SUS, e não apenas do município. Assim, a política de pessoal deve possibilitar uma contratação mais moderna, estabelecer critérios de plano de carreira, de avaliação de desempenho, com metas de produtividade das equipes.

Pode-se dizer que o SUS desenvolveu-se de forma vigorosa, mas o crescimento em vários aspectos foi sem qualidade, com vínculos precários de 
trabalho e com relações de trabalhadores sem humanização. $\mathrm{O}$ trabalhador da saúde foi vilipendiado por políticas públicas neoliberais, as quais descomprometem o Estado da responsabilidade pela assistência à saúde da população e precarizam, deliberadamente, o trabalho. Para que o SUS dê certo, os trabalhadores não podem estar à margem desse debate; é a partir dele que as ações de saúde se desenvolvem, como relata esse sujeito:

Da gestão, se envolvendo mesmo com as questões da saúde, muitas vezes percebemos que há um discurso, mas que não passa de discurso, não há aprofundamento, de estar participando efetivamente, estar ouvindo as pessoas, os trabalhadores, naquilo que acham que é preciso ser mudado, modificado. Então, eu sinto essa falta na gestão, essa preocupação de estar realmente ouvindo, e a partir desse ouvir, fazendo políticas que vão de encontro aos interesses da população. (S1)

A integralidade inscrita na Constituição e buscada pelos sujeitos entrevistados resgata a visão do ser humano em sua totalidade - promove ao mesmo tempo ações de promoção, proteção e recuperação da saúde. Integralidade é a confluência de vários saberes de uma equipe de saúde, no espaço concreto e singular dos serviços de saúde, os quais devem estar organizados e preparados de forma aberta para receber as necessidades de saúde não previstas em rotinas e protocolos.

A recuperação da imagem da saúde pública passa também pela construção de diretrizes que garantam a responsabilidade sanitária dos entes federados, dos serviços e das equipes de saúde. A gestão compartilhada da saúde requer um processo de responsabilização entre os três níveis de governo e da própria equipe, ou seja, quem é responsável por qual situação e qual o papel de cada profissional e da equipe no cotidiano. Requer, do mesmo modo, a definição de prioridades estabelecidas por meio de metas nacionais, estaduais, regionais e municipais. A implementação do SUS demonstra o compromisso com a gestão compartilhada, priorizando a saúde local e regional, conforme reflete o sujeito entrevistado:

Eu acredito que tem um avanço, porque antes você ficava muito amarrada ao Estado, muito amarrada ao Ministério, ao Governo Federal, com propostas que, por exemplo... tinha uma proposta do Ministério, e você tinha que desenvolver no seu município exatamente como era solicitado. Ficava muito amarra- 
do com algumas questões. Eu acho que isso tirava o caráter regional da coisa, aquele caráter local, porque a cidade de Franca é completamente diferente de (outra pequena), mesmo estando no mesmo Estado a sessenta quilômetros de distância. Então, tem características diferentes, cultura diferente. Assim, não adianta você pegar um negócio e dar para o País todo fazer igualmente. (S2)

Desta maneira, é preciso pensar localmente, definir prioridades, mas considerar as necessidades que são nacionais/estaduais, considerando que a área da saúde exige várias soluções para os problemas. Inclusive, a dinâmica das situações apresentadas nos serviços de saúde precisa de mecanismos de gestão mais flexíveis, por exemplo, na compra de medicamentos, na autorização de procedimentos, no encaminhamento de questões que, muitas vezes, são dificultadas pela burocracia da administração.

Os gestores do SUS precisam gerir diversidades de informações, de alternativas; precisam desenvolver uma postura profissional envolvida com o SUS. Para Santos (2008, p.10), “a maior parte dos gestores do País [...] não tem interesse da participação também da sociedade na tomada de decisões", portanto, a questão da formação do gestor interfere no funcionamento do SUS, para melhor ou para pior. A construção do conhecimento na saúde passa necessariamente pelo compromisso, como está demonstrado nesta fala: "A gestora é uma pessoa que entrou na saúde pública sem saber nada de saúde pública, e hoje ela domina saúde pública. Então, se quer saber alguma coisa... ela tem informação, ela sabe e conhece" (S4).

$\mathrm{Na}$ busca de soluções para mais eficiência e resultados dos serviços públicos de saúde, além do financiamento e da política de pessoal, tornam-se imperiosas inovações no modelo de gestão. Nas grandes questões do subfinanciamento e da precarização das relações de trabalho, não só o governo, mas todos os movimentos sociais devem ser irredutíveis. Portanto, o movimento de repolitização do SUS, com uma clara estratégia de mobilização social, com um movimento que retoma a Reforma Sanitária aproximando dos desafios atuais do SUS é, para Nelson Santos (2008), fundamental.

Desse modo, o horizonte para a educação permanente é a efetiva concretização dos princípios do SUS. Avançar nessa direção significa não só ampliar e aprofundar as reflexões, mas, sobretudo, revertê-las em ações concretas, disseminando os conhecimentos desenvolvidos. Espera-se, pois, que o processo de educação permanente funcione como fonte de conhecimento, 
objeto de planejamento e transformação das práticas de saúde, e contribua para a compreensão do funcionamento das políticas públicas.

Na base dessa edificação está o "trabalho de formiga" de todos os trabalhadores da saúde dos mais diversos níveis hierárquicos e de conhecimento. Lembra-se também de que eles estão submetidos ao conjunto de determinações sociais, econômicas, políticas e trabalhistas dado por sua inserção como trabalhadores assalariados, mas são eles os responsáveis mais próximos pelo desenvolvimento das atividades voltadas para o ser humano em sua integralidade. Em função disso, surgem requisições expressivas relacionadas às dimensões tecnológicas de gestão, gerenciamento, organização e, sobretudo, de conhecimento do SUS e de seu funcionamento - condições estas que vão sublinhar sua necessidade da educação permanente em saúde.

\section{O conceito de saúde e o modelo de atenção}

Essa questão da saúde. O que é saúde? É um conceito, e como tal é muito amplo. [...] A gente ouve falar o que é saúde, e a gente, às vezes, não pensa o que é saúde. Então, é interessante a gente pensar. Eu aprendi que saúde é a ausência de doença, saúde é um estado de bem-estar físico, espiritual, social. Tudo isso é saúde. Mas a saúde pode ser entendida como uma qualidade de vida, não é? É bastante amplo, e a qualidade de vida envolve vários fatores. Então, cada vez fica mais complexo esse estudo do que é a saúde, do que é o bem-estar, do que é a qualidade de vida. [...] Sempre faço essa indagação, e aí também levo o usuário a essa reflexão. (S1)

Hoje eu trabalho com o conceito de que você tem que ser feliz, bem-estar, físico e emocional. Eu acho que saúde não é só você não ficar doente, igual a Organização Mundial de Saúde fala. Mas acho que é trabalhar essa questão de viver bem, ter qualidade de vida. Por exemplo, a gente trabalha muito na minha equipe esse conceito [...]. Tem esse relacionamento bacana com o usuário [...], é qualidade de vida. Isso é saúde, entendeu? A gente trabalha lá (na unidade de saúde) muito com esse conceito de promover saúde, promover lazer, promover a satisfação. [...] Justamente, acho que esse conceito de trabalhar a felicidade, o bem-estar, trabalhar as coisas boas. (S2)

A saúde é o bem-estar social. Não, não, saúde envolve tudo, a vida da pessoa. É o bem-estar geral, o bem-estar social, natural, físico [...]. É, é tudo isso, o econômico, a habitação, tudo da vida da pessoa. (S3) 
Um conceito que a Organização Mundial de Saúde coloca é que a saúde compreende o bem-estar físico, mental, social, tudo. É isso aí que te incentiva, porque aqui (na unidade de saúde) a gente atende muito caso nesse sentido. [...] Mas é um problema social? É um problema de saúde? Você tem que ver esse indivíduo como um todo, né? As condições de vida dele, as vezes ele tá bem, você olha pra ele e ele tá bem. Ele não tá resfriado, não tá com dor de garganta, não tem doença [...], mais ele não tem nem água tratada na casa dele. Tem a água que vem pelo encanamento, mas ele não trata dentro de casa, não tem uma horta pra que ele possa, às vezes, não tem o que comer, e isso aí me incentiva, me estimula bastante. [...] Eu vejo como um todo. Se eu faço uma visita domiciliar, eu vejo desde o chão que ele pisa e que tem possibilidade daquele idoso escorregar, cair, né? Igual ontem, eu fiz uma visita pra uma senhora que fez uma cirurgia até grande, problema vascular, e a casa dela é de escada; e ela tá obesa e ela tem retorno no médico. Gente, mas como que ela vai no retorno médico? Como que eles carregam? Então, a gente enxerga isso como um todo, e eu não olho só a parte da doença. Isso é uma visão ampliada que tenho. (S4)

Observa-se nas falas dos sujeitos a visão ampliada do conceito de saúde. A perspectiva de qualidade de vida vai além da concepção que restringe a saúde ao bem-estar físico, social e mental. Como também mostra a visão integral prevista na regulamentação do Sistema Único de Saúde (SUS), indicando que o reconhecimento dos determinantes e condicionantes da saúde tem sido considerado no atendimento à saúde do usuário. Acredita-se que esse aspecto é influenciado pela experiência prática dos trabalhadores da saúde e pela própria formação que todos os sujeitos entrevistados têm, ampliando o conhecimento a respeito da saúde, de seu conceito e de seus determinantes.

A criação do SUS, como se evidenciou anteriormente, é uma conquista de cidadania na história da sociedade brasileira, que, organizadamente, participou do processo democrático nos anos 1980 e indicou propostas para a elaboração da Constituição de 1988. Defendeu garantias individuais e coletivas ao estabelecer um sistema de Seguridade Social abrangente e direitos universais de acesso à saúde, previdência e assistência social.

Os sujeitos expressam em suas falas a relação da saúde com qualidade de vida, bem-estar, felicidade e uma postura dos trabalhadores da saúde voltada para a perspectiva de promoção da saúde. A análise crítica e reflexiva do próprio trabalho é revelada nos questionamentos constantes - do conceito ampliado e da compreensão de saúde a partir das experiências construídas 
no cotidiano, apontando os limites e as dificuldades de desenvolver ações e serviços no paradigma da promoção da saúde. Há preocupação com as condições de vida e o atendimento das necessidades básicas.

Construído como política pública universal, fundamentado em princípios e diretrizes de descentralização, integralidade, participação da comunidade, equidade, igualdade e preservação da autonomia, o SUS é compreendido, enquanto processo, como uma reforma social. Sua formulação aponta a responsabilidade do Estado, da sociedade e de todas as suas instituições no compromisso para que a saúde seja reconhecida, ao mesmo tempo, como direito de todos e dever do Estado e um recurso para o desenvolvimento social, econômico, político e cultural do País.

Ao pensar o SUS como política de Estado criada em um contexto capitalista totalmente adverso e em sua implementação, que se inicia no final dos anos 1980 e se expande na década de 1990, há de se considerar que esse processo acontece em um momento de fortalecimento do neoliberalismo, que assinala uma perspectiva restrita do Estado e de justiça social. Ao ser priorizado o mercado financeiro, provocou-se a estagnação econômica e a concentração de riqueza e, consequentemente, aumentou a pobreza e o agravamento das condições de vida da população.

Para Behring \& Boschetti (2006), as políticas sociais no capitalismo, por mais que tenham a função de reduzir as injustiças e desigualdades sociais, produzem efeitos excludentes a grandes parcelas da população. Assim, os direitos constitucionais, garantidos legalmente pelo movimento da sociedade brasileira, enfrentam esse momento de inflexão do Estado democrático. A implementação da Constituição no Brasil, e de suas políticas públicas previstas, chega em um momento em que mundialmente as políticas sociais seguem a perspectiva e os princípios neoliberais. Portanto, o reconhecimento da saúde como direito universal não significou a ruptura esperada, porque não conseguiu transformar, ao menos o modelo de atenção proposto, que predomina curativo, centrado nas doenças e especialidades e voltado para o mercado.

Ao enfocar a integralidade da assistência no SUS, “[...] entendida como um conjunto articulado e contínuo das ações e serviços preventivos e curativos, individuais e coletivos, exigidos para cada caso em todos os níveis de complexidade do sistema" (Brasil, 1990a, art. 7º), indicou-se o princípio básico para a organização desse processo. As medidas para implementação 
desse modelo de atenção encontrou na descentralização político-administrativa e na regionalização e municipalização a finalidade de facilitar o acesso da população às ações e serviços de saúde, como se observa na fala de um trabalhador:

Acho que desde que o SUS foi implantado até hoje, teve muitas mudanças. [...] Eu acho que a descentralização, a municipalização das ações foi muito legal, porque dá uma liberdade para os gestores de administrar isso de uma maneira melhor, entendeu? Eu acho que isso é o grande diferencial do Sistema; a municipalização e a regionalização das ações de saúde. (S2)

Entretanto, os limites e as dificuldades provocadas pela redistribuição de poder, competências e recursos têm impedido a efetivação desse processo. Os trabalhadores entrevistados apontam o que poderia ser diferente: "Sabe o que poderia ser diferente? Que abrissem mais, ampliar mais vagas. Esse serviço de especialidades pra outros lugares menores, não é? No caso aqui da nossa cidade" (S3). E ainda: "Teria tudo pra dar certo [...]. Então, o SUS... ele fica preso nessas questões burocráticas. Da questão de referenciar a hierarquização. Não tem acesso às especialidades" (S4). Tanto isso é verdadeiro que se pode observar neste outro relato:

Mas, por exemplo, igual aqui pra nós, município pequeno, quando você fala: "Vamos falar da ressonância", não faz; do ecocardiograma é uma luta. Pra fazer ecocardiograma, acredita? E aqui não tem consultório e nem laboratório. [...] Então dá a entender isso, não é? Que aqui não precisa. Que a população aqui não precisa disso. [...] Porque isso o SUS prevê. Então aí, acho que atravanca um pouco na parte de referência, porque depende da microrregião, não depende do município. (S4)

A construção da rede hierarquizada na saúde não tem conseguido se efetivar e superar a implementação heterogênea, entre outras questões colocadas pelas diversidades locais e regionais, sociais, econômicas, políticas e administrativas. Conforme analisaram Sarreta \& Bertani (2006), o que teoricamente possibilitaria um nível de organização social favorável para a introdução das ações de saúde propostas para a população encontra explicações no senso comum, como uma "fase inicial" de implementação da políti- 
ca de saúde. Leva-se em consideração que o SUS saiu de sua adolescência e completa 20 anos em 2008: tempo demais para quem dele precisa, tempo de menos para imprimir uma mudança de direção social tão radical.

Neste momento de redefinir e repensar a prática do SUS, principalmente em razão das situações apresentadas nos serviços de saúde, é indispensável que a sociedade brasileira reconheça o SUS como um projeto em construção, um modelo de atendimento que traz em sua constituição a ideia de cidadania e de justiça social, a ser implementado em uma sociedade injusta e desigual. Abranger a amplitude de sua cobertura é fundamental para a consolidação plena, o que não se dará espontaneamente: exige a participação e uma vigilância constante em defesa dos direitos sociais, tão duramente conquistados.

As últimas décadas no Brasil evidenciaram o agravamento da pobreza e dos níveis de desigualdades e das precárias condições de vida. De acordo com dados do Instituto Brasileiro de Geografia e Estatística (IBGE), na década de 1990, apenas $10 \%$ da população detinha $51,5 \%$ da renda nacional, em contrapartida, os $10 \%$ mais pobres detinham apenas $0,7 \%$ (Bravo, 2006). Portanto, entender saúde condicionada por um determinado aspecto, por exemplo, pela falta de alimentação adequada, a qual gera situações de desnutrição e doenças oportunistas, não era difícil. Mas aceitá-la como uma das faces da questão social e, assim, intrinsecamente, determinada pelas condições de vida e de trabalho, já a torna quase impossível de ser alcançada, pois apresenta duas grandes dificuldades. A primeira, pelo gigantismo da proposta diante da fragmentação da ação dos Ministérios e a distribuição de verbas públicas feitas sem observância próxima de sua destinação e sem os resultados esperados. O segundo impasse, quase consequência do primeiro, implica a decisão do investimento político em um benefício social que, por sua profundidade e amplitude da abrangência na vida da população, pode ser considerado um bem maior, uma vez que "saúde envolve tudo, a vida da pessoa" (S3).

Essa ausência de priorização das necessidades da saúde na sociedade ocorre, frequentemente, sem que qualquer debate tenha sido realizado e nem que seus determinantes sociais tenham sido exigidos com ênfase. Supõe-se que esse esclarecimento conceitual tenha ficado restrito aos meios acadêmicos e que a população não reconheça uma política de saúde identificada com a vida, mas com a falta de medicação e de vagas em hospitais, com o alívio 
rápido da dor e da doença. A questão da prevenção, da vida saudável, não é nem ao menos citada como prioridade essencial nas pesquisas de opinião, que precedem cada período eleitoral. Essa ausência de pressão social pode, muitas vezes, induzir o poder público municipal a considerar preferencialmente uma posição imediatista na resolução de problemas pontuais urgentes e concretos.

Conforme Vasconcelos já alertava em 1997, as limitações impostas pela luta da sobrevivência imediata não devem ser encaradas como obstáculo às ações de saúde, mas como uma característica da realidade. Esta nos mostra que, apesar da vinculação dos problemas de saúde aos modos de produção do capital e a forma de distribuição das riquezas refletida diretamente nas privações do cotidiano, essa relação não aparece ao senso comum como "problema de saúde", muito menos relacionado com a sobrevivência da espécie humana no planeta. Na melhor das hipóteses, as condições sociais surgem como formas complexas e contínuas no entrecruzar de suas diversas e múltiplas interferências, ou seja, permite afirmar que a apropriação das determinações sociais delimitadoras do pensamento pela população em geral é, portanto, condicionada sócio-historicamente e extraída da complexidade do real.

Ajustar o destino enquanto humanidade ao que não é consensual seria, acima de tudo, negar a capacidade de transformação dos sujeitos, de superação do que está determinado, para alcançar um novo patamar de existência. Entender que não há transfiguração possível visando à equidade e justiça social na atual estrutura da sociedade engessada, definitivamente, pelo capitalismo é aceitar o modo de ver o mundo das classes dominantes, uma vez que, no dizer marxista, a visão dessa elite é a própria visão predominante.

A possibilidade de transformação social só vem ameaçar os que estão confortáveis diante do que está posto, e para isso necessitam manter as coisas como estão, ainda que premidas pelas dificuldades da maior parte da população. Mas talvez já seja a hora desses limites delimitados pelo poder nas relações sociais entre "desiguais" poderem acender a "aventura da transformação" e iluminar um caminho considerado fechado, sem alternativas e, portanto, imobilizante.

Algumas iniciativas não podem ser desconsideradas, ainda quando se constate certa passividade do povo brasileiro. A reação da sociedade na busca de seu espaço legítimo na área da saúde deu-se por meio do processo participativo e estratégias mobilizadas por ocasião da Reforma Sanitária e da 
construção do SUS (Brasil, 2006a). A adoção dessas propostas pela Constituição de 1988 e regulamentação na Lei Orgânica da Saúde (LOS), pelo conjunto das Leis 8.080 e 8.142 em 1990, e as posteriores normatizações e ajustes como política pública de saúde foram efetivadas via programas e projetos complementares. Toda sua elaboração visava à aproximação das medidas de saúde à população brasileira em geral como um direito.

Segundo Barbosa (1992, p.9), ao concretizar-se o SUS como uma política pública que tem suas diretrizes baseadas na universalidade da atenção, foi involuntariamente criado um espaço parecido com uma "terra de ninguém". A reação das forças do mercado foi manifestada na tentativa de aniquilar a proposta da universalidade da coisa pública de qualidade como direito e, aos poucos, impôs-se a percepção de que "se é de todos, e ainda por cima gratuito, é ruim”. Os planos e seguros de saúde apropriaram-se das inseguranças societárias da classe média, que se sentiu ameaçada de cair no "valo comum da pobreza e abandono" (Barbosa, 1992, p.9). Não se pode negar certo fundamento nesses temores, pois essa tem sido a condição destinada à população empobrecida no País, pois está excluída das vantagens da civilização, desde a informação, passando por condições gerais de vida e até do poder. Igualar-se pela universalização significava ficar em uma maca nos corredores dos grandes hospitais públicos, significava esperar meses por um atendimento, sabendo-se que os privilegiados de sempre passariam ao largo pelo sistema de compadrio e do "jeitinho brasileiro" (Barbosa, 1992).

A conclusão a que chegaram as classes consideradas de renda média não poderia ser mais óbvia: se uma pessoa não é indigente, não é, portanto, obrigada a se sujeitar à boa vontade e caridade de outros; e se ela não conta com a proteção de alguém poderoso, que se cuide: pague, ainda que duas vezes, para alcançar a prestação do mesmo serviço que é seu de direito, definido constitucionalmente e financiado pela sociedade geral via impostos. A regra consensual dominante passa a ser o pagamento duplicado de um serviço de saúde frequentemente de má qualidade.

Esse clima de "salve-se quem puder", constituído pelo pensamento prático-utilitário (Kosik, 2002), cria uma falsa compreensão dos acontecimentos, vistos de forma isolada e fragmentada, e afasta o conhecimento real para fixar-se na aparência dos fenômenos sob a ótica ilusiva que esta constitui à sua essência. Portanto, a forma fenomênica da realidade, ao revelar-se como estrutura acabada e mistificada natural, devido ao seu caráter de indepen- 
dência, fixa-se como imutável, e essa suposta familiaridade (pseudoconcreticidade) isola as condições facilitadoras do pensamento transformador.

São muitas as condições determinantes que interferem dia a dia na relação saúde-doença, mas, partindo da experiência concreta cotidiana, pode-se afirmar que mesmo diante de uma situação de desigualdade social extremada, e passado o primeiro momento de indignação e revolta, tudo se acomoda e permanece como está sem maiores conflitos. Essa constatação vem resultando em passividade ou na escolha de caminhos alternativos para os problemas pessoais e familiares, solução individualista que caracteriza as situações de desagregação do coletivo social.

Verifica-se que a apropriação do caráter imutável e "natural" da realidade quebra as condições de transformações, visto que dissolve o antagonismo econômico inerente à sociedade capitalista. Exime também as possibilidades de aproximação da totalidade para que o homem tome consciência de si como ser social, expresso nas palavras de Luckács (1989, p.35) "[...] como simultaneamente sujeito e objeto do devir histórico e social".

O entendimento dos acontecimentos que gravitam em torno da questão da saúde e de sua falta e do acesso ao atendimento, ao ser visto de modo parcial e destacado de uma realidade maior, gera a "naturalização" das baixas condições de qualidade de assistência e gestão, situando-as como despidas de história. Essa compreensão empírica do funcionamento da sociedade no Brasil provocou um rebaixamento geral de expectativas em relação ao desempenho do sistema público nacional de saúde - qualquer coisa está benfeita, considerando a quem se destina: o decantado "serviço feito para pobre". Cabe aos pobres, cerca de 70\% da população (IBGE, 2000), desdobrar-se em agradecimentos pela generosidade governamental da gratuidade do atendimento, ainda que deficitário e incompleto, que recebem.

A saúde, vista de modo isolado, inviabiliza a luta por sua efetivação com qualidade, como se pode perceber pelo afastamento da temática das reivindicações políticas e da descrença generalizada na própria força da temática, no embate social. Na realidade, a política de saúde encontra-se nos assuntos de maior relevância das campanhas eleitorais, objetivada nas mais diferentes ideologias. Contudo, sua materialização prática no dia a dia dos serviços de saúde está pautada pelo descaso político. Isto pode ser verificado na falta de incentivo e esclarecimentos sobre o SUS, acrescentada dos baixos salários pagos aos trabalhadores da saúde. Esses fatores tornaram o serviço prestado 
algo sem muita importância, resistindo contra a falta de recursos, em condições de trabalho penosas e cobranças sociais elevadas. Toma-se como exemplo esta fala:

$\mathrm{Eu}$ acredito que se paga muito pouco ao trabalhador do SUS [...]. Percebo que falta maior dedicação. Por exemplo, hoje o médico, ele não fica, não tem o vínculo na unidade, precisa ter vários empregos, porque ele não conseguiria sobreviver com esse salário. Mesmo outro profissional, se investir em maior formação o salário não acompanha. Muitos profissionais são criticados por isso, mas eu vejo que também tem o outro lado, o lado da razão, da não valorização financeira do bom trabalhador do SUS. [...] Mas se você for ver em serviço de consultório (privado), de convênio, ele ganha muito mais. Então, hoje ninguém quer ir para o serviço público por isso, porque eles (médico) têm que ter uma dedicação e não ganham o que eles investiram pra ganhar. [...] Mas a gente percebe que o médico que fica no PSF oito horas, ele tem o engajamento com a equipe, com a unidade, porque tem diferença salarial. É uma outra coisa que eu acho que podia ser diferente, entendeu? Porque, às vezes, os médicos, as enfermeiras reclamam. Se você for ver o nível de produção de trabalho, eu acho que é a mesma. A responsabilidade é a mesma. Então, por exemplo, enquanto eu atendo quarenta minutos ou meia hora uma consulta, ele atende dez, quinze minutos. Então, assim, o meu vínculo com a unidade é quatro, oito horas, o dele é o número de consultas. [...] Eu acho que interfere. Acho que tinha que melhorar a questão financeira, tinha que pagar melhor o trabalhador, valorizar o trabalhador. (S2)

Notadamente, vive-se e trabalha-se em uma sociedade em que o valor das pessoas é medido pela remuneração que recebem e ostentam e pela concessão de gratificações simbólicas, tais como o reconhecimento social e a valorização da imagem profissional. Como nenhum dos componentes motivacionais acontece, completa-se o quadro de carências: o atendimento do SUS torna-se um "serviço prestado por trabalhadores pobres para doentes pobres". Longe vai ficando o aspecto integrado e integrador da 8 8 Conferência Nacional de Saúde (1986) e o conceito ampliado de saúde então defendido. O relato abaixo ilustra essa ideia construída socialmente:

Eu não concordo, mas tem todo um envolvimento atrás dessa parte financeira. O SUS paga mal, então é assim, vamos trabalhar mal. Tem uma regra. Há, tem sim. Alguns têm, de que o SUS é pra pobre. Eu acho que infelizmente tem; 
aqui até que é muito pouco, e talvez por essa boa relação que nós temos com os usuários e outros serviços da cidade. (S4)

Na verdade, essa ideia construída da política pública de saúde é portadora de um projeto socioeconômico para a sociedade incluindo a saúde: um SUS pobre para os $80 \%$ de pobres, de baixo custo e de pouca resolutividade, focalizado nessa população, e simultaneamente complementar para os $20 \%$ que consomem planos privados de saúde, com foco nos bens e serviços mais especializados e de maior custo, passando por um festival de terceirizações e desvios de demanda para o mercado. Observa-se a análise desse sujeito quando ressalta a relação da universalidade e integralidade com a demanda colocada pelo mercado: "Por isso que acaba perdendo essa qualidade no atendimento. O que é caro o SUS faz. Porque ele cobre tudo. Eu ainda não descobri nada que o SUS não faça" (S4).

Gastão Campos (2006b) destaca que o SUS apresenta uma nova configuração para o desenho da saúde pública brasileira, em especial pela ampliação da descentralização. Mas, como o próprio autor mostra em outro estudo, o viés dado pelo modelo ainda não assumiu integralmente os princípios do SUS, uma vez que permanecem hegemônicos em nossa sociedade "[...] restos do antigo modo de organizar a atenção, [...] centrado em hospitais, especialistas, com pequeno grau de coordenação e de planejamento da assistência” (Campos, G. W. S., 2007b, p.303).

Para que ocorra de fato a incorporação dos determinantes sociais e econômicos no processo de saúde-doença, é necessário pensar na formação e desenvolvimento de novas práticas e saberes. Trata-se de um movimento que passa pela objetivação do trabalho no interior do SUS, determinado pelas condições objetivas postas pelas exigências da demanda e das novas práticas. Desse modo, a Política Nacional de Educação Permanente em Saúde constitui um instrumento para encaminhar o trabalho no SUS em uma perspectiva coletiva e de promoção da saúde.

O desafio mais persistente para a implementação do SUS passa a ser, então, a integralidade como forma de evitar que o sistema de saúde pública se constitua de programas focais voltados aos menos favorecidos. A importância da integralidade está assinalada pelos trabalhadores da saúde entrevistados, que buscam no atendimento aos usuários considerar outros aspectos além da doença. "Você tem que ver esse indivíduo como um todo [...]. 
As condições de vida dele, às vezes, ele tá bem, você olha pra ele e ele tá bem. Ele não tá resfriado, não tem doença [...], às vezes, não tem o que comer [...]" (S4).

Assim, o SUS, que compreende um conjunto de ações individuais e coletivas, englobando promoção da saúde, prevenção de agravos, tratamento e reabilitação, tem na Saúde da Família a estratégia para transformar o modelo de atenção. Outro aspecto, entretanto, é que a própria organização desse Programa, o Saúde da Família, para funcionar necessitava da contratação de profissionais cujas categorias nem eram regulamentas ainda como as de "[...] auxiliar e técnico de saneamento, agente de vigilância sanitária, agentes de saúde" (Bravo, 2006, p.105). Essa situação foi agravada pelo processo de admissão desses trabalhadores, que seguiu o viés da precarização e da terceirização, não viabilizando a qualidade e humanização dos serviços de saúde a serem prestados.

O componente estratégico para o desenvolvimento de um amplo sistema de atenção básica deve atingir pelo menos $80 \%$ dos problemas de saúde da população, como previsto para os sistemas universais. O sistema brasileiro, no entanto, seguiu um caminho contrário: pautou-se no hospital, dando pouca atenção à promoção da saúde. Por esse motivo, a discussão da atenção básica no Brasil tem de ser cada vez mais articulada com a viabilidade do SUS, para que a prioridade não seja diagnosticar doenças, e sim atuar também na prevenção de suas causas.

Os benefícios práticos desse modelo de assistência são facilmente percebidos: humanização do cuidado, redução dos índices de reinternação e diminuição do risco de infecção hospitalar, não se esquecendo de que o custo de um paciente internado é muito grande. A saída é o rompimento do modelo hospitalocêntrico (Campos, 2006a) e o fortalecimento da atenção básica para o acesso do usuário ao SUS. Isso se passa também pelo investimento na formação dos trabalhadores com perfil para o trabalho no SUS, para que o compromisso e responsabilidade permitam a criação de vínculo, inclusive o compromisso dos gestores e do próprio Ministério.

$\mathrm{Eu}$ acho que tem mudado. Aquele modelo curativo, hoje com o PSF, por exemplo, você vê que mudou muito. Infelizmente, no nosso município a gente não tem uma cobertura $100 \%$ do PSF. Mas o bairro, o território que a gente tem o PSF, a gente observa que o avanço na saúde das pessoas é muito maior, porque 
muda o modelo de caráter curativo para o preventivo, promoção. Então, muitas vezes as pessoas vão desnecessariamente na unidade de saúde; elas ocupam vagas de quem realmente necessita. Por quê? Porque, às vezes, tem uma ociosidade; às vezes tem aquela cultura de ir ao médico sempre; às vezes vai ao médico também só pra visitar o médico. Então, quando ela recebe (o trabalhador), que senta, que escuta, orienta, isso faz um diferencial nesse modelo de atenção, que é um modelo mais preventivo do que aquele curativo. (S2)

Observa-se que o modelo de atenção proposto pelo SUS é considerado adequado, mas salienta-se a necessidade de rever seu funcionamento, a questão moral e ética, segundo a análise deste trabalhador em seu depoimento:

Essa parte de abraçar a causa. Parte do compromisso, da responsabilidade. [...] É outro aspecto que faz toda a diferença. É o que eu tava te falando da laranja podre; não adianta nada eu trabalhar compromissada, aplicando os princípios do SUS, né? Tudo direitinho e você não. Aí estraga, porque você interrompe a rede. [...] Porque um depende do outro, não é? Mesmo vindo lá de cima, é uma rede; começa lá no Ministério e vem descendo. Se tem a interrupção, falta energia; rebenta um fio, falta energia. (S4)

O modelo de atenção prevalecente no Brasil é voltado para as condições agudas e não atende as necessidades de saúde. É preciso pensar a integralidade da atenção como um conjunto de valores que movem a ação na saúde, e o ponto central desses valores é reconhecer o direito à saúde e o direito de todos a ter acesso às tecnologias disponíveis. A sociedade brasileira ampliou o conceito de saúde; isso significa pensar que a integralidade da atenção é o grau de conhecimento que a sociedade tem de seus direitos e como ela é tratada na esfera estatal, para, assim, apropriar como cidadão do direito à saúde, com referência na emancipação.

Desse modo, o Brasil tem grandes desafios. Apresenta 53 milhões de pessoas vivendo abaixo da linha da pobreza, com $1 \mathrm{real} /$ dia por indivíduo, e $90 \%$ dos recursos mundiais na saúde são consumidos por apenas $10 \%$ da população (Conass, 2006). Outro aspecto nesse quadro, apresentado pela Opas/OMS na América Latina: uma análise de 1995 a 2004 mostrou que a saúde na região se depara com vários desafios, e as reformas do Estado não trouxeram melhoria na qualidade de vida das populações: "Na região, 27\% dos habitantes não têm serviços básicos de saúde permanentes, e 17\% dos 
recém-nascidos não recebem assistência prestada por pessoal qualificado" (OMS, 2007).

Enfim, é preciso enfrentar esses desafios para superar as dificuldades apresentadas na saúde. Um desses desafios é construir reformas sociais efetivas, solidárias e participativas, seguindo as proposições da Reforma Sanitária brasileira, para superar as contradições políticas no SUS. Relata este trabalhador:

Precisa de mudanças relacionadas à administração, gerenciamento, do gestor etc. [...]. Essas questões de engajamento, de qualidade de atendimento, dos relacionamentos. É nesse sentido, da gestão se envolvendo mesmo com as questões da saúde. Muitas vezes, percebemos que há um discurso, mas que não passa de discurso, não há aprofundamento para estar participando efetivamente, estar ouvindo as pessoas naquilo que elas acham que é preciso ser mudado, modificado. Então, eu sinto essa falta na gestão, essa preocupação de estar realmente ouvindo, e a partir desse ouvir, fazendo políticas que vão ao encontro dos interesses da população. (S1)

A ênfase na participação da sociedade e dos próprios usuários nos serviços e nas ações de saúde, para o fortalecimento do poder local e regional, foi influenciada pelo debate acerca de um novo paradigma para a saúde de todos os povos. Ao refletir sobre essa mudança de paradigma na saúde, é bom enfatizar o papel do movimento internacional pela Promoção da Saúde, iniciado com os ambientalistas na década de 1970.

Posteriormente, na reunião mundial no Canadá, em 1986, ${ }^{3}$ o reconhecimento de outros determinantes além do biológico no processo de saúdedoença favoreceu as discussões acerca dos cuidados ambientais, das ações comunitárias e do fortalecimento e desenvolvimento das habilidades individuais (Lourenço \& Bertani, 2006). Esse aspecto foi decisivo nas mudanças significativas no pensar fazer da área da saúde, trazendo um acréscimo para a qualidade de vida e, ainda, consagrou a reorientação dos serviços de saúde pública, que no Brasil foi incorporado ao movimento da Reforma Sanitária.

3 "A primeira Conferência Mundial de Promoção da Saúde foi realizada em Ottawa, Canadá, em 1986, e ficou mundialmente conhecida como a Carta de Ottawa (1996), cujo grande mérito foi o de clarificar o conceito que lhe deu o nome" (Andrade \& Barreto, 2002). 
No contexto mundial, a Conferência de Alma Ata (1978) enuncia a saúde como um direito humano fundamental: destaca a determinação econômica e social da saúde e sua importância para o desenvolvimento do País. Essa Conferência assinala a responsabilidade dos governos para os cuidados primários de saúde e atendimento das necessidades humanas básicas, a importância da renda familiar, da oportunidade de emprego, da nutrição, educação, habitação, saneamento básico e meio ambiente como condicionantes favoráveis para a saúde de todos os povos e cuja realização requer a ação de muitos outros setores sociais e econômicos, além do setor saúde.

A ênfase está na "proximidade com as pessoas", como relata Starfield (2002, p.31). De maneira simplificada, significa que em uma "visita domiciliar", ver desde "o chão que ele pisa e que tem possibilidade daquele idoso escorregar", observar se tem "água tratada na casa dele", ou ainda se tem "o que comer", ou seja, enxergar "isso como um todo, e eu não olho só a parte da doença" (S4), como evidencia o trabalhador entrevistado.

Os componentes fundamentais da atenção primária à saúde são: a educação em saúde; saneamento ambiental, especialmente de água e de alimentos; programas de saúde materno-infantis, inclusive imunizações e planejamento familiar; prevenção de doenças endêmicas locais; tratamento adequado de doenças e lesões comuns; fornecimento de medicamentos essenciais; promoção de boa nutrição; e medicina tradicional.

O novo paradigma enunciado, ratificado pela Organização Mundial de Saúde (OMS), extrapola a direção centrada na doença e enfoca a atenção à saúde na direção da autonomia das pessoas, a participação dos povos na execução de seus cuidados de saúde, do meio ambiente sustentável e da utilização de tecnologia acessível a todos os governos como caminhos para atingir qualidade de vida para todos os povos (Opas, 1978).

Para atingir "Saúde para Todos no Ano 2000", a Assembleia Mundial de Saúde, reunida em Alma Ata, enunciou um conjunto de princípios para construir a base da atenção primária, e propõe que os serviços de saúde deveriam ser: dirigidos por valores de dignidade humana, equidade, solidariedade e ética profissional; direcionados para a proteção e promoção da saúde; centrados nas pessoas, e que os cidadãos influenciem os serviços e sejam responsáveis pela saúde; baseados em financiamento sustentável, para que permitam cobertura universal e acesso equitativo, como mostra Starfield (2002).

A atenção primária à saúde foi definida em Alma Ata como: 
Atenção essencial à saúde baseada em tecnologia e métodos práticos, cientificamente comprovados e socialmente aceitáveis, tornados universalmente acessíveis a indivíduos e famílias na comunidade por meios aceitáveis para eles e a um custo que tanto a comunidade como o país possa arcar em cada estágio de seu desenvolvimento, um espírito de autoconfiança e autodeterminação. É parte integral do sistema de saúde do país, do qual é função central, sendo o enfoque principal do desenvolvimento social e econômico global da comunidade. É o primeiro nível de contato dos indivíduos, da família e da comunidade com o sistema nacional de saúde, levando a atenção à saúde o mais próximo possível do local onde as pessoas vivem e trabalham, constituindo o primeiro elemento de um processo de atenção continuada à saúde (OMS, 1978, p.2).

Starfield (2002) estuda profundamente esse tema e orienta a necessidade de entender a atenção primária como foco de organização e porta de entrada dos sistemas de saúde e o locus de responsabilidade pela atenção aos usuários e populações, e reafirma a confiança de que a essência da atenção primária é fundamentalmente simples. Esclarece as duas metas principais da atenção primária no sistema de serviços de saúde: a primeira para otimizar a saúde da população, investindo no conhecimento avançado sobre a causa das enfermidades, o manejo das doenças e a maximização da saúde; e a segunda, para minimizar as disparidades entre os subgrupos populacionais, de modo que determinados grupos não estejam em desvantagem com relação ao acesso de serviços e alcance do nível de saúde.

Adotada como estratégia no desenvolvimento da promoção da saúde, a atenção primária compreende a educação sobre os principais problemas de saúde e sobre os métodos de prevenção correspondentes. Essa concepção, à medida que amplia a visão do cuidado em sua dimensão setorial e o envolvimento da própria população, extrapola o campo de ação dos responsáveis pela atenção convencional dos serviços e valoriza a saúde como um componente central do desenvolvimento humano.

Nesta referência, a organização e o funcionamento da atenção primária estabelecem uma postura de planejamento voltada para a autorresponsabilidade e a participação de todos os setores e campos de atividade associados ao desenvolvimento nacional e comunitário. Em especial, questiona os setores agropecuário, de alimentação, indústria, educação, habitação, obras públicas, comunicações etc., exigindo esforços coordenados de todas as áreas, 
porque expressam a relação dos cuidados primários de saúde com o desenvolvimento econômico, social, político e cultural do País.

Para ilustrar a proposta sugerida em Alma Ata (1978), a tabela a seguir mostra a intenção de uma nova orientação na atenção convencional para a visão de atenção primária.

Tabela 3 - Orientação da atenção médica primária à atenção primária à saúde.

\begin{tabular}{lc}
\hline Convencional & Atenção Primária \\
\hline Doença & Enfoque \\
Cura & Saúde \\
& Prevenção, atenção e cura \\
\hline Tratamento & Promoúdo \\
Atenção por episódio da saúde & Atenção continuada \\
Problemas específicos & Atenção abrangente \\
\hline Convencional & Atenção Primária \\
\hline & Organização \\
\hline Especialidades & Clínicos gerais \\
Médicos & Grupos de outros profissionais \\
Consultório individual & Equipe \\
\hline & Responsabilidade \\
\hline Apenas setor de saúde & Colaboração intersetorial \\
Domínio pelo profissional & Participação da comunidade \\
Recepção passiva & Autorresponsabilidade \\
\hline
\end{tabular}

Fonte: Starfield (2002, p.33).

Ao identificar a saúde nessa amplitude, traz ao conceito um enfoque que valoriza as capacidades pessoais, sociais, emocionais, políticas e culturais, uma vez que depende de recursos interligados e influenciados, como justiça social, paz, respeito e ecossistema estável, o que leva a considerar a necessidade de repensar os valores que estão direcionando e organizando a vida em sociedade. O sujeito entrevistado destaca o trabalho intersetorial: "A inter- 
setorialidade é importante. Precisa construir essa rede. [...] O trabalho integrado com outros setores ajuda muito também, amadurece bastante a gente. E existe essa cumplicidade entre os outros setores, que ajuda" (S4).

A discussão do direcionamento das políticas públicas saudáveis e a criação de ambientes favoráveis à saúde, associados à reorientação do sistema de saúde nesse novo paradigma, ganha dimensão na Conferência de Ottawa (1986), e aprofunda a discussão acerca da promoção da saúde como um "[...] processo de capacitação da comunidade para atuar na melhoria de sua de vida e saúde, incluindo a participação no controle deste processo [...]" (Brasil, 2002, p.19).

A atenção primária está, portanto, relacionada diretamente com a diminuição das iniquidades na saúde. As desigualdades existentes na sociedade exigem políticas públicas que busquem incrementar o acesso das pessoas a bens e serviços promotores de saúde, estabelecendo, como analisa o próprio Ministério da Saúde (2002), alta prioridade aos grupos mais desprivilegiados e vulneráveis, particularmente quanto aos cuidados primários, um aspecto vital para a equidade em saúde. Assim, a busca de soluções e a construção de parcerias intersetoriais são indicadas como alternativas para identificar interesses comuns e resolver problemas, influenciando positivamente na participação ativa da comunidade, nas mudanças das condições sanitárias e na maneira de viver, constituindo uma cultura de saúde.

Para a OMS, como demonstram os estudos de Starfield (2002), conforme o conhecimento se acumula, os profissionais tendem a especializar-se, as profissões na área da saúde ficam cada vez mais fragmentadas. A atenção à saúde deve considerar o contexto no qual a doença ocorre e no qual o usuário vive, porque as enfermidades raramente existem de forma isolada. O profissional da atenção primária deve integrar a atenção para a variedade de problemas de saúde que os indivíduos apresentam com o tempo. Conclui que a sociedade não dispõe de recursos ilimitados para fornecer serviços de saúde - a atenção primária é mais acessível e permite múltiplos diagnósticos, e a atenção subespecializada é mais cara e menos acessível, além de ameaçar o objetivo da equidade.

Dessa perspectiva, a OMS analisa a saúde como de um indivíduo ou grupo, quando é capaz, por um lado, de realizar aspirações e satisfazer necessidades e, por outro, de lidar com o meio ambiente. A saúde é, portanto, "[...] vista como um recurso para a vida diária, não o objetivo dela; abranger os 
recursos sociais e pessoais, bem como as capacidades físicas, é um conceito positivo" (Starfield, 2002, p.21).

Starfield (2002) esclarece que os determinantes que influenciam a saúde são muitos, como as características culturais e comportamentos da população e dos usuários, o ambiente social e físico e os serviços de saúde/prática médica. Assim, a saúde de um indivíduo ou população é determinada por sua combinação genética, mas grandemente modificado pelo ambiente social e físico, por comportamentos que são cultural ou socialmente determinados e pela natureza da atenção à saúde oferecida. As causas são complexas, envolvem fatores antecedentes, como o contexto ambiental, as condições sociais e as relações sociais e os fatores de risco genético, como exemplo, as causas ou fatores que operam diretamente: água contaminada, segurança, habitação; e indiretas: estresses, acesso à atenção médica. Assim,

a condição de saúde de uma comunidade é determinada pelas características ambientais daquela comunidade, as características comportamentais de sua população e o senso de conexão e de graus de coesão social na comunidade. O mesmo ocorre para as condições sociais, como níveis de renda e riqueza na população, o nível geral de educação na comunidade e as características de oportunidades de trabalho disponíveis para seus membros (Starfield, 2002, p.23).

Nessa perspectiva, a saúde está diretamente associada à vantagem social, para Starfield (2002, p.26), "em termos absolutos". Portanto, a quanto mais recursos sociais os indivíduos e as comunidades tiverem acesso, maior a probabilidade de uma vida melhor, e quanto maiores as disparidades na riqueza em qualquer população, maiores as disparidades na saúde. A desigualdade de renda amplia a desigualdade de saúde e diminui a expectativa de vida. A autora esclarece ainda que o serviço de saúde é um dos determinantes diretos na melhoria da saúde, a partir da obtenção de efetividade, se estiver orientado para a atenção primária.

Os resultados da pesquisa realizada por Starfield (2002) em diversos países, quando mede os impactos e os custos da atenção primária à saúde, demonstraram que quanto mais forte o sistema de atenção primária, melhores os resultados e custos. Os dados dessa comparação mostraram que os países onde as políticas de saúde conduzem à atenção primária refletiram em maiores vantagens para crianças e jovens e na vida adulta, e onde a distribuição 
de recursos era conforme as necessidades de saúde, e não da demanda, tinham melhor nível de saúde.

Desse modo, as propostas de Alma Ata - universalizantes, integrais e participativas, sob influência dos movimentos sociais, nacional e internacional, por melhores condições de vida e de saúde - foram integradas no âmbito nacional às experiências de medicina comunitária, representando significativo avanço e contrariando o tradicional modelo de saúde. Associa-se, nesse contexto, a busca de medidas governamentais para legitimar-se, politicamente, e controlar as insatisfações da população e a busca da sociedade brasileira pelos direitos sociais e de saúde.

Portanto, os estudos indicam que a atenção primária representa a estratégia para transformar esse modelo de atenção. A atenção à saúde focalizada na comunidade, com práticas que apontam para o estabelecimento de novas relações entre os profissionais de saúde, os indivíduos e as famílias possibilitam criar condições que conduzam à construção de um modelo de promoção da saúde e atenção à saúde mais democrático, participativo e solidário. Essa perspectiva é valorizada pelo sujeito entrevistado:

Acho que o PSF podia cobrir 100\% da cidade. Infelizmente, a gente só tem uma equipe, e mesmo assim eu vejo que podia ser melhorada, mudada, na questão do PSF. Acho que o PSF se perdeu um pouco. Aqui era mais valorizado, tinha bons profissionais trabalhando, não é uma política forte. Eu acho que tem que ser, entendeu? Acho que o PSF ajuda muito, [...], cria oportunidades de qualidade de vida. (S2)

No entanto, a reorganização das práticas de atenção à saúde requer o investimento no processo de formação permanente, para que o profissional seja capaz de agir com criatividade e senso crítico e desenvolva uma prática que envolva ações de promoção, prevenção, recuperação e reabilitação. $\mathrm{O}$ SUS cresceu de forma vigorosa, mas o crescimento foi sem qualidade, sem políticas adequadas e sem a preparação de seus trabalhadores. Diante dessa complexidade, um dos desafios na saúde é o investimento na gestão do conhecimento. Exige aprender um novo modo de fazer saúde e a busca de novas alternativas.

Portanto, a formação de um profissional para participar do planejamento, organização, desenvolver e avaliar ações que respondam às necessidades da comunidade, articulando os diversos setores envolvidos na promoção da 
saúde. E, para que isso aconteça, é preciso uma permanente interação com a comunidade, no sentido de mobilizá-la e estimular sua participação. Assim, a atenção à saúde - e não apenas a assistência médica - incorpora novos espaços de atuação profissional, requerendo efetivo compromisso dos trabalhadores com a concepção ampliada de saúde. Por outro lado, a integralidade da atenção, reconhecida como um princípio que contempla as dimensões biológicas, psicológicas e sociais do processo saúde-doença, deve ser difundida como uma nova cultura da saúde na formação profissional. Afirma-se, dessa maneira, que o paradigma político-assistencial torna-se também político-pedagógico, orientando as propostas de educação na saúde.

A educação permanente em saúde desempenha sua função, quando está envolvida em uma prática de transformação que traduz um processo do conhecimento, um processo dialético de criação e recriação, desenvolvendo a reflexão crítica sobre a prática/trabalho. Deve ter como objetivo central a transformação do processo de trabalho, orientando-o para uma constante melhoria da qualidade das ações e serviços de saúde. Assim, a produção de conhecimentos em saúde caracteriza-se como um processo gerado no trabalho fundamentalmente participativo, já que resulta de diferentes e complementares experiências entre a equipe de saúde e a comunidade.

São essas questões, portanto, que indicam o processo educativo como um investimento na formação para o trabalho, em que tal processo possa definir as demandas educacionais, e não a demanda do mercado capitalista. Assim, o horizonte para a educação permanente é a efetiva concretização dos princípios do SUS e o acesso universal à saúde.

\section{O significado do trabalho na área da saúde}

Do trabalho na saúde? Os meus sentimentos e minhas ideias? Olha, são muitos sentimentos. Porque é um trabalho de relacionamento humano que engloba uma complexidade. Então, ora temos sentimento de alegria, euforia, bemestar, quando percebemos que conseguimos o nosso objetivo de favorecer para que a pessoa se sinta bem, se sinta satisfeita com o atendimento que recebe. [...] Ajudo com orientação, e quando a gente sente que foi útil às pessoas [...], gera esse sentimento de satisfação. E, por outro lado, acontecem também situações em que a gente se vê frustrado, indignado, revoltado, excluído, tem um certo sentimento negativo, isso também acontece. [...] É devido a essas situações com- 
plexas, relacionadas aos usuários, ao gerenciamento, relacionadas à situação socioeconômica. Então, são "n" situações que geram esse sentimento, e que nem sempre estamos em condições de abordar. Por vezes, acabamos entregues a sentimentos pessimistas, ideias de desistir da profissão e coisas desse tipo. [...] É uma área muito interessante. Porque a gente busca o bem-estar pra gente e para outras pessoas; é uma área que dá para se aprofundar e desenvolver muito. (S1)

Ah, meus sentimentos... logo que eu me formei, interessei muito, optei pela área de saúde pública. [...] Comecei a trabalhar nessa área voltada pra saúde pública [...], vi realmente que tinha muito a ver com minha formação. [...] Eu gosto de trabalhar lá (na cidade pequena), porque eu tenho a possibilidade de exercer todos os papéis na saúde pública. É bem amplo. Lá eu tenho essa possibilidade. Acho que a cidade pequena, ela dá essa possibilidade, porque o número de funcionários é menor; o número de funcionários capacitados ou especializados é menor também do que uma cidade grande, mas não tem essa divisão que tem aqui. Então, a gente tem essa possibilidade de participar de tudo e fazer de tudo um pouco. Faço atendimento aos usuários, faço atendimento a adultos, faço atendimentos a criança e adolescentes. Tô atuando também na parte de gestão, [...] estou dentro da Secretaria, eu participo de todos os projetos. [...] Eu tive oportunidade, o gestor lá confiou e confia em mim e no meu trabalho. [...] Adoro fazer o que eu faço, entendeu? Acho que o profissional que trabalha na saúde pública, qualquer trabalho... você tem que exercer com comprometimento, com vontade. [...] Eu acho que a gente tem que trabalhar onde as pessoas precisam de bons profissionais. (S2)

$\mathrm{Ah}$ ! Eu gosto muito, tanto que eu fiquei na saúde e não fui pra outro setor (da prefeitura). Gosto muito, eu gosto assim, de atender o pessoal, de ajudar no que for possível, entendeu? E a gente fica um pouco frustrada também, pela política de saúde que é bem falha. [...] Em termos assim, por exemplo, de encaminhamento, esse pessoal que realmente precisa... demora muito pra ser atendido, as especialidades. [...] É. Por exemplo, pra encaminhar nas especialidades, muita gente pergunta por que é só pediatria e psicologia. E as cirurgias? Então, nesse sentido a gente fica meio frustrada. (S3)

Eu sou suspeita pra falar dos meus sentimentos, mas eu sinto que aqui é um pouco diferente do que eu vejo em outros locais [...] Porque a gente abraça a causa mesmo, [...] porque aqui a gente tem um trabalho assim, integrado, muito bom. [...] Não sei se é porque é uma cidade pequena, você conhece todo mundo, então tem certo vínculo de amizade também. Então eu corro atrás, e quando eu não consigo, eu vou pra Secretária de Saúde. [...] e a Secretária também, ela dá 
assim, de corpo e alma no trabalho. Não é aquele que é só figura, ela trabalha mesmo. Então é onde que assim... eu sinto um diferencial, claro que tem hora que a gente desanima, é difícil. [...] Porque você pensa: hoje não consegui, mas a gente corre atrás, se você gosta do que você faz. Quando eu estudava na Faculdade, imagina [...], pensava: não quero saber de saúde pública, mas é claro, a gente não conhece, né? Não sabe o quê que é. Não conhece a política de saúde, porque é fascinante quando a gente conhece. [...] Eu acho que o trabalho é responsabilidade, porque não adianta você firmar um compromisso e você não cumprir com ele. [...] Então acho que é muito assim, responsabilidade. Aqui tem muita gente que é assim, mas tem muitos que não se importam, vem, cumprem o horário e vai embora. Não tem tanto compromisso e nem a responsabilidade de cumprir esse compromisso. (S4)

As ideias e os sentimentos dos sujeitos entrevistados, relacionados ao empenho e compromisso com a política pública de saúde, o Sistema Único de Saúde (SUS), evidenciam os desafios e os limites para o desenvolvimento do trabalho na área. Como se observa, as falas expressam sentimentos tanto positivos quanto desmotivadores e conflituosos. São sentimentos diretamente influenciados pelas condições de trabalho - políticas, sociais, técnicas, éticas, materiais -, que se referem à valorização do trabalhador como sujeito protagonista do processo de trabalho, mas também a desvalorização do trabalhador e de seu próprio trabalho expressa na postura da chefia, direta e/ ou indireta, e no direcionamento dado ao trabalho.

Outro aspecto observado passa pelas condições de vida da população usuária dos serviços de saúde, pois a pobreza, o sofrimento, a falta de perspectiva interferem na disposição do trabalhador, levando-o a sentimentos de incapacidade e impotência diante da realidade apresentada. Por outro lado, torna-se evidente que quando o trabalhador se sente útil e percebe que sua ação ajuda no atendimento oferecido ao usuário, há um sentimento de satisfação pessoal e profissional, subjetiva e concreta.

Desse modo, as contradições apresentadas pelo trabalho na saúde são complexas e envolvem uma postura de compromisso com a vida humana. Merece lembrar que desde a criação do SUS, a questão do trabalho e de seus trabalhadores foi considerada como prioridade para o desenvolvimento da assistência em saúde. A respeito dessa questão, a reflexão de Iamamoto (2005) acrescenta essa análise do trabalho, condição fundamental para a realização das pessoas, atividade que mediatiza a satisfação das necessidades huma- 
nas, seja material ou intelectual. Deveria ser, portanto, uma condição de realização nessa área.

É por meio do trabalho que o homem se afirma como um ser que dá respostas prático-conscientes aos seus carecimentos, às suas necessidades.[...] Por meio do trabalho o homem se afirma como ser criador, não só como indivíduo pensante, mas como indivíduo que age consciente e racionalmente. Sendo o trabalho uma atividade prático-concreta e não só espiritual, opera mudanças tanto na matéria ou no objeto a ser transformado, quanto no sujeito, na subjetividade dos indivíduos, pois permite descobrir novas capacidades e qualidades humanas (Iamamoto, 2005, p.60).

Nessa abrangência, a condição de trabalho na saúde está associada ao exercício da autonomia, competência, da realização do potencial intelectual e emocional, do desenvolvimento da criatividade e produtividade, das capacidades e habilidades pessoais (Opas, 2001 apud OMS, 2007). Desse modo, tem relação direta com os locais e as condições de trabalho, que devem ser constituídos como espaços de realização e satisfação pessoal e profissional, individual e coletivamente.

O direcionamento dado à política de saúde pelo gestor direciona e influi na postura de trabalho e em relação ao próprio trabalho. Portanto, a realização dos trabalhadores da saúde e o compromisso com o trabalho, pelas falas dos sujeitos, têm relação com a qualidade do atendimento oferecido e as responsabilidades assumidas e cumpridas. Assim como com o conhecimento exigido durante esse processo, pelas próprias características e natureza do trabalho na saúde, que guarda algumas especificidades. Conforme Deluiz (2001, p.8, destaque do autor),

um trabalho reflexivo, no qual as decisões a serem tomadas implicam na articulação de vários saberes que provêm de várias instâncias, tais como a formação geral (com ênfase no conhecimento científico), a formação profissional (com ênfase no conhecimento técnico) e as experiências de trabalho e social (qualificações tácitas), e que são mediados pela dimensão ético-política.

Embora o trabalho persista como o eixo da centralidade da vida em sociedade, os estudiosos da área vêm demonstrando que a eficiência da organização da produção e da própria formação profissional não se refletem igual- 
mente nas relações sociais, na saúde e na qualidade das condições de vida deterioradas pelos novos valores sociais de competitividade, racionalização e otimização da produção e da mão de obra. É preciso lembrar que, a partir da década de 1980, tanto o trabalho quanto o direito foram institucionalizados nas formas de cidadania e direitos sociais na Constituição de 1988. Paradoxalmente, ao final do século XX e início do século XXI, avolumam-se ainda as iniquidades e as desigualdades sociais e materializam-se em grande escala mudanças contemporâneas com implicações diretas na gestão e na divisão social do trabalho.

As mudanças no contexto econômico, político, social e cultural, provocadas pelo modelo de desenvolvimento econômico adotado no início dos anos 1970, do pleno emprego e da intervenção do Estado na esfera econômica, apoiavam-se na presença de um Estado de Bem-Estar Social (Welfare State) e esboçava políticas sociais que visavam permitir a produção e reprodução da força de trabalho. As novas configurações que o capitalismo foi assumindo e a crise do padrão de acumulação capitalista geraram transformações no mundo da produção e revelaram as fragilidades do modo de organização do trabalho industrial baseado no taylorismo/fordismo: o trabalho não qualificado, fragmentado, rotineiro. Sua alteração por formas produtivas desregulamentadas, acordou-se em denominá-la como uma especialização flexível.

Essas metamorfoses mundiais que afetam o trabalho correspondem, atualmente, à exigência de profissionais cada vez mais qualificados para que possam aumentar o grau de competitividade com reflexos para a excelência da produção. Contraditoriamente, há a redução do valor dos salários, uma vez que o trabalhador torna-se polivalente, e embora não seja especializado, está apto a executar mais de uma função e se sustente em um processo produtivo flexível (Antunes, 1999).

Pode-se resumir essa questão como voltada ao atendimento das demandas do mercado, que, impulsionado pela modernização, favorece a troca muito rápida dos produtos ainda novos, mas precocemente considerados ultrapassados tecnologicamente. Trata-se de pensar o mundo da produção, como já enfatizado por Antunes (1999; 2006), não atado exclusivamente ao processo produtivo industrial, mas com seus pressupostos estendidos para a área de serviços e para as relações sociais, substancialmente abaladas no oferecimento de condições para a autonomia e crescimento humano. 
Desde os primeiros movimentos para a Reforma Sanitária brasileira até a atual fase de implementação do SUS, várias foram as iniciativas não só de ampliar o número de trabalhadores da saúde, mas de implementar uma política de formação e desenvolvimento para a incorporação de seus princípios e diretrizes.

No entanto, isso sempre foi determinado pelos momentos institucionais e políticos do País, influenciado pela imposição do grande capital internacional de expressão neoliberal, empurrando as medidas efetivas de formação dos trabalhadores do SUS através das décadas de 1980, 1990 e 2000.

Para Bravo (1996), essas décadas são consideradas cheias de transformações para a saúde pública brasileira com a construção do arcabouço teóricolegal do SUS e de inovações que representaram uma nova configuração de pensar, desenvolver e produzir serviços e assistência em saúde. Os princípios da universalidade de acesso, da integralidade da atenção, da equidade, da participação da comunidade, da autonomia das pessoas e da descentralização dos serviços de saúde colocados no cenário tornaram-se paradigmas do SUS, com enfoque centrado no município para a reorganização do sistema de saúde.

A transformação no sistema de saúde, associada ao processo de municipalização, levou à expansão de empregos no setor público de saúde, principalmente no âmbito municipal. Machado (2006) estuda o quadro de Recursos Humanos (RH) no contexto da Reforma Sanitária brasileira e destaca as transformações que ocorrem no mercado de trabalho em saúde a partir do final da década de 1970 e que se intensifica nos anos 1990, período em que acontece a consolidação do SUS. ${ }^{4}$ Com o processo de municipalização o setor saúde no Brasil,

4 Em pesquisa realizada, constatou-se que: "Em 1976, o setor público municipal contava com apenas 25.854 empregos; o setor público federal, com 98.528; e o estadual, com 60.094. Em 1992, o setor público estadual passou a ser responsável por 315.328 empregos e o municipal por 306.505 empregos. Na década de 1990, o setor público municipal passa a ter liderança dos empregos, totalizando quase 800 mil em 2002. Já o volume dos empregos federais, além de não apresentar crescimento nestas últimas décadas, perdeu capacidade de absorção de mão de obra, decaindo de 98.528 empregos, em 1976, para 96.064, em 2002, conforme dados do Instituto Brasileiro de Geografia e Estatística (IBGE). Em outras palavras, o crescimento da oferta de empregos no setor público, nestas três décadas, se deu a partir da expansão do 'parque sanitário municipal'. Em 1976, representava 11\% do total de empregos públicos do SUS e, em 2002, aumentou para $65 \%$. Pode-se dizer que o setor federal, que sempre teve hegemo- 
pode ser considerado um dos maiores do mundo e corresponde à estratégia de ser um sistema de saúde que atua em mais de cinco mil municípios, distribuídos nos seus estados e regiões. Com quase setenta mil estabelecimentos de saúde (públicos e privados) e cerca de 500 mil leitos hospitalares, este setor gera na ordem de dois milhões de empregos diretos em saúde. Da mesma forma, em plena era tecnológica, que se caracteriza pela redução do uso de mão de obra intensiva, o setor Saúde é um dos maiores geradores de empregos da economia, configurando-se de grande relevância social não só pelos serviços prestados à população como pela sua enorme capacidade geradora de empregos [...]. Os dados mostram que, nestas últimas décadas, a capacidade instalada do setor apresentou crescimento espetacular em todos os anos, passando de menos de 400 mil empregos na década de 1970 para mais de dois milhões na primeira década do atual século (Machado, 2006, p.18, destaque do autor).

O mercado de trabalho em saúde apresenta características próprias, configurando-se em um mercado de profissionais especializados, "[...] uma vez que em qualquer atividade exercida na saúde - seja ela com exigência de escolaridade mais elevada (nível superior) ou desenvolvida por trabalhadores com pouca escolaridade (nível elementar) -, pressupõem-se profissionais com qualificação específica, seja ela formal ou empírica" (Machado, 2006, p.20). Assim, o mercado de trabalho em saúde é um setor de produção e prestação de serviços com características próprias, além de ser um setor com prestação da assistência de "relevância pública", e apresenta o "uso intenso e diversificado da mão de obra".

Como esse setor, no Brasil, não esteve imune às mudanças decorrentes da nova ordem de organização produtiva, nem tampouco dos reflexos da reformulação do papel do Estado, a saúde não foi assumida, efetivamente, como uma área de proteção e regulação do Estado. Assim, a consolidação do SUS, durante a década de 1990, não esteve acompanhada de uma política efetiva para orientar a formação de seus trabalhadores, seguindo a nova concepção proposta de universalidade, integralidade e equidade de maneira descentralizada.

A adoção dos preceitos neoliberais nesse período, pelo governo federal, produziu efeitos prejudiciais na implementação do SUS, com a precarização

nia na prestação e na assistência à população, passa em apenas duas décadas a ser o 'lanterna' no ranking da assistência, invertendo posição com o setor municipal” (Machado, 2006, p.13). 
do trabalho e levou a problemas diversos, como a prestação de serviços por meio da terceirização, mudanças no processo de trabalho e nos vínculos trabalhistas, a forma de remuneração, bem como o modo de trabalhar sofreu alterações significativas; foi influenciado por ambientes de trabalho competitivos e individualizados.

Nos anos 1990, o governo federal adotou uma política de incentivo para a abertura de novas instituições de formação universitária. ${ }^{5}$ Nesse sentido, Machado (2006, p.22) reflete que o quadro de Recursos Humanos (RH), nesse período, no contexto da Reforma Sanitária brasileira de implementação de um sistema universal e integral à saúde, foi "a década perdida para os trabalhadores da saúde [...]”, um "período da antipolítica de RH”. Para ele, o SUS atravessou "[...] a década de sua consolidação sem se preocupar com seus trabalhadores", sem organizar uma política compatível com a concepção universalista.

A análise de Bravo e Menezes (2007, p.19) indica que um dos aspectos centrais da política de saúde a partir da década de 1980 é a questão da terceirização dos trabalhadores de saúde, que se consolida nos anos 1990. As autoras identificam que os impactos da política macroeconômica na política de saúde impedem o enfrentamento das questões centrais, tais como: "[...]a universalização das ações; o financiamento efetivo; a Política de Gestão do Trabalho e Educação na Saúde e a Política Nacional de Medicamentos".

Assim, as propostas para os trabalhadores da saúde refletiam o contexto da época e abrangiam uma extensa pauta de caráter reivindicatório: a isonomia salarial e o plano de cargos e salários; o caráter multiprofissional da composição das equipes; e a incorporação de agentes populares de saúde remunerados e sob a coordenação do nível local do sistema de saúde, para cumprir demandas de atenção primária e educação em saúde, como a capacitação e reciclagem permanentes e a formação dos profissionais integrada ao sistema de saúde regionalizado e hierarquizado (Machado, 2006).

Nesse cenário histórico, o Sistema Único de Saúde (SUS) foi criado e vem sendo construído com tensões e disputas. Na lógica econômico-capitalista,

5 Segundo Machado (2006, p.21), o quadro das “[...] novas escolas de saúde no período compreendido entre 1995 e final de 2002: as escolas de medicina passam de 85 para 119; as de enfermagem, de 108 para 334; as de odontologia, de 89 para 161; e as de farmácia, de 56 para 347 ". 
a saúde está situada no setor de serviços, "integrando um conjunto das atividades denominado serviços de consumo coletivo" (Deluiz, 2001, p.8), e apresenta por meio do SUS o compromisso político de desenvolver a assistência à saúde em seus diferentes níveis, como direito de todos e dever do Estado. Entretanto, o setor de serviços sofre os impactos das transformações tecnológicas e institucionais e é atingido do mesmo modo pelos processos de precarização das relações de trabalho.

O que se verifica, portanto, é um sistema de saúde que está contextualizado nas mudanças mundiais de paradigmas políticos, econômicos, sociais, culturais; mudanças que afetam o próprio trabalho e os trabalhadores, com introdução de tecnologias que exigem maior base de educação e formação profissional. Assim, o trabalho nesse paradigma torna-se cada vez mais complexo e intelectualizado, polivalente, autônomo, em equipe, uma vez que o avanço tecnológico provocou novas exigências em lidar com o novo, o incerto e o casual nas atividades cotidianas (Deluiz, 2001).

Ao referir-se à natureza do trabalho na saúde, Deluiz (2001, p.8) esclarece que "[...] reveste-se da imprevisibilidade das situações, nas quais o trabalhador ou o coletivo de trabalhadores tem que fazer escolhas e opções todo o tempo, ampliando-se as operações mentais e cognitivas envolvidas nas atividades". Desse modo, é um trabalho influenciado pelas incertezas decorrentes da indeterminação das demandas, pelas descontinuidades e pela necessidade de prontidão no atendimento a todos os casos, inclusive os excepcionais. Um trabalho na análise de Deluiz (2001, p.8) em que “[...] é preciso capacidade de diagnóstico e de solução de problemas, aptidões para tomar decisões, enfrentar situações em constantes mudanças”. De tal modo, “[...] não pode seguir uma lógica rígida como a racionalidade dos critérios da produção material, sendo difícil a sua normatização técnica e a avaliação de sua produtividade".

As características desse trabalho são, portanto, a complexidade, a heterogeneidade e a fragmentação:

A complexidade decorre da diversidade das profissões, dos profissionais, dos usuários, das tecnologias utilizadas, das relações sociais e interpessoais, das formas de organização do trabalho, dos espaços e ambientes de trabalho. A heterogeneidade revela-se pela diversidade dos vários processos de trabalho que coexistem nas instituições de saúde e que têm, muitas vezes, uma organização 
própria e funcionam sem se articular de forma adequada com os demais processos de trabalho. A fragmentação encerra várias dimensões, tais como a fragmentação conceitual, ou seja, a separação entre o pensar e o fazer: a fragmentação técnica, caracterizada pela presença cada vez maior de profissionais especializados e a fragmentação social, que estabelece relações rígidas de hierarquia e subordinação, configurando a divisão social do trabalho no interior e entre as diversas categorias profissionais (Deluiz, 2001, p.24).

Observa-se que essa complexidade do trabalho na saúde provoca diversos sentimentos, tão presentes nas falas dos sujeitos, "[...] ora temos sentimento de alegria, euforia, [...] de favorecer para que a pessoa [...] se sinta satisfeita com o atendimento que recebe. [...] E, por outro lado, acontecem também situações em que a gente se vê frustrado, indignado, revoltado, excluído [...], isso também acontece" (S1). Outro aspecto ressaltado relaciona-se às oportunidades dos trabalhadores da saúde expressarem o conhecimento e as capacidades nos atendimentos realizados, exemplificando: "Faço atendimento aos usuários [...] a gente tem essa possibilidade de participar de tudo e fazer de tudo um pouco, [...], eu participo de todos os projetos [...]. Adoro fazer o que eu faço [...]" (S2); "Gosto muito [...] de atender o pessoal, de ajudar, no que for possível (S3), e ainda, "[...] aqui a gente tem um trabalho assim, integrado, muito bom" (S4).

Verifica-se desde a década de 1980 "[...] a influência do planejamento estratégico e da administração participativa e a preocupação com o maior envolvimento e comprometimento dos recursos humanos, tendo por objetivo a melhoria da qualidade do trabalho" (Deluiz, 2001, p.9). No entanto, apesar das inovações desencadeadas, persiste um forte componente gerencial taylorista/fordista na organização do trabalho na saúde, caracterizado por postos de trabalho separados, mas encadeados, com tarefas rotineiras, e intensa divisão técnica do trabalho com a separação entre concepção e execução.

As transformações dessa década afetaram profundamente a classe-quevive-do-trabalho, denominação dada por Antunes (1999, p.196) para caracterizar a classe trabalhadora, "[...] a totalidade dos assalariados, homens e mulheres que vivem da venda da sua força de trabalho e que são despossuídos dos meios de produção [...]", os quais sofrem a perda de direitos trabalhistas, do emprego formal, são submetidos ao subemprego e trabalho temporário, vivem em uma condição de despolitização. A sociedade considera esse trabalhador, para Lima (2003, p.21), 
como sendo um trabalhador que tem uma formação geral básica e sólida e que permite ser treinado e retreinado conforme as exigências do mercado, subordinado à lógica da exclusão social; cujas competências se definem pela capacidade de abstração, polivalência, flexibilidade e criatividade, adequados às exigências da composição intercapitalista global.

A educação emerge, então, como técnica para instruir o trabalhador para esse mercado. No discurso hegemônico, a educação é um instrumento necessário, segundo Lima (2003, p.21), “[...] para o desenvolvimento dentro dos padrões exigidos pela nova economia e condição de possibilidade de diminuição do fosso social que separa os países tecnologicamente industrializados e os países em desenvolvimento no interior do capitalismo internacional". $\mathrm{O}$ autor chama a atenção para o fato de que o trabalho visto como mercadoria e, consequentemente, quem o representa, o trabalhador, sofre consequências no desenvolvimento capitalista não apenas econômicas, mas de valores éticos, morais, ideológicos. Enfim, a influência dos organismos e instituições sociais (nacionais e internacionais) que representam essas mudanças determinam a formação do trabalhador conforme os interesses de produção e reprodução da sociedade conduzida pelos ideais neoliberais (Lima, 2003).

A complexidade inserida na discussão da formação decorre principalmente de seu caráter intersetorial, multiprofissional e multidisciplinar, com limites gerados inclusive pela própria constituição social e histórica das profissões de saúde no Brasil. Portanto, as ações e intervenções no campo dos recursos humanos em saúde demandam do setor proposições pactuadas entre diversos atores. Dessa perspectiva, torna-se fundamental contribuir para o debate sobre a formação na saúde, considerando os diversos aspectos que conformam o cenário atual, para realizar proposições e enfrentar as necessidades que aparentemente estão imersas no SUS, tanto para reforçar os aspectos positivos alcançados quanto para a construção de alternativas que permitam avançar na consolidação de um perfil profissional crítico, participativo e responsável.

Lima (2003) reflete que, neste início do século XXI, pensar a formação profissional requer a consciência de que a sociedade está marcada por elementos que interferem no cotidiano das pessoas e alteram as relações de trabalho, impõem planejamento do cotidiano, novas habilidades e apontam para a necessidade de uma qualificação permanente. Mas o autor ressalta que 
pensar a educação e o trabalho no contexto atual exige compreender que o processo de formação humana, de humanização, obtém-se por meio da relação homem-natureza mediado pelo trabalho, e "[...] é nesta relação e suas mediações que emerge a educação [...] compreendida como se apresentou em seu processo histórico constitutivo" (Lima, 2003, p.18).

A educação na saúde, nessa perspectiva apresentada, inserida no processo de trabalho, torna-se instrumento que pode contribuir para transformar a realidade brasileira e a própria saúde, focalizando seu conteúdo nos princípios e no paradigma sanitário norteadores do SUS, para, assim, desenvolver competências, não apenas para identificar os determinantes do processo saúde-doença, mas estabelecer sua articulação com a prática profissional - a produção do cuidado, o diagnóstico, a ação humanizada, a produção do cuidado em saúde.

Esse paradigma, promotor de autonomia, leva a desenvolver as capacidades política, pedagógica, técnica eética para as práticas específicas na saúde, e o processo de trabalho torna-se um processo educativo, favorecendo a aprendizagem e potencializando a capacidade de realização dos sujeitos de compreensão e análise do próprio trabalho a partir das vivências experimentadas no cotidiano.

Demo (1994) ensina a importância não só dessa competência técnicocientífica, da competência política, visando à integralização da competência humana para o cuidar profissionalizado no SUS como condição para a cidadania do trabalhador e do usuário. Para o autor, são dimensões que ajudam a humanizar o conhecimento e vincular seus fins políticos e sociais, uma competência política voltada para os fins históricos que abarque a compreensão da saúde como produto social, o que significa articular o trabalho com compromisso ético-político. A competência humana assim entendida pensa um trabalhador completo, um sujeito integral no mundo do trabalho.

Retomando a ideia anterior, a formação profissional em saúde deve relacionar conteúdos técnicos que identifiquem os determinantes do processo saúde-doença com a competência esperada. Torna-se fundamental ampliar a formação dos trabalhadores da saúde para a compreensão global do processo de trabalho, para o desenvolvimento de modelos de atenção voltados para a qualidade de vida.

A construção de competências pertence aos trabalhadores como sujeitos desse processo, uma vez que compreende a competência humana de, "[...] 
saber humanizar o conhecimento para que este possa servir aos fins éticos da história e não descambe em mera instrumentação da competitividade", ou ainda, a competência humana voltada "para a cidadania, e, como esta, apontar para o processo emancipatório”, que significa "[...] o processo histórico de conquista da condição de sujeito coletivo autônomo”, reflete Demo (1997, p.12). É fundamental, na área da saúde, o desenvolvimento da consciência para participação política e coletiva, valorizando o desenvolvimento humano integral e a autonomia das pessoas para o cuidado com sua própria saúde.

Portanto, a reorientação do modelo assistencial no SUS demanda uma formação profissional que leve em consideração as efetivas necessidades político-pedagógicas da saúde, para evitar a reprodução de modelos e possa instrumentar novos conteúdos para a realidade brasileira, em razão dos princípios e do paradigma sanitário norteadores do SUS (Mendes, 1996). Significa que, em uma sociedade capitalista, em meio a políticas de expressão neoliberal, ter consistência nos referenciais e no enfrentamento dos desafios para possibilitar, em termos políticos e educacionais, que a educação contribua para a universalidade, a inclusão e a cidadania, ainda que em pleno contexto de "globalização" excludente.

O pensamento de Torrez (2001, p.49) completa essa ideia quando, sabiamente diz que, em meio a políticas de expressão neoliberal, "não tem firmeza em nada”, mas é necessário ter firmeza nos referenciais - éticos, políticos, científicos - para que a educação em saúde contribua para que os trabalhadores da saúde atuem na perspectiva do cuidado em saúde com competência e cidadania. O sentido neoliberal da educação é uma formação voltada para o trabalho sem reflexão, sem crítica e sem qualidade. É preciso, portanto, romper com a visão superficial dos problemas sociais e, ainda, resistir à tendência que caminha em prejuízo de conquistas históricas por uma educação e uma saúde de qualidade (Torrez, 2001). Assim, é preciso dar concretude a esses desafios, sobretudo de rompimento com a ordem social vigente, para que a formação na saúde busque agregar os trabalhadores, os gestores, os formadores e os usuários para a defesa do SUS realmente comprometida.

A compreensão de que problemas complexos como o do trabalho no setor da saúde, que envolve conhecimentos procedentes de diferentes campos e disciplinas, e que não possuem solução simples leva a ter clareza de 
que a interdisciplinaridade e a intersetorialidade são fundamentais para que se possa compreender/explicar os fenômenos e buscar soluções adequadas. Esse aspecto, se despertado, leva à busca de parcerias e de experiências diversificadas, que fomentam a educação na saúde e a formação permanente dos trabalhadores.

Assim sendo, as condições apresentadas pela ordem neoliberal e pelo conservadorismo no conhecimento, sob o pretexto da reforma, da modernização, e de projetos movidos pela ideia do lucro, pelo consumo da educação e da saúde, dão a dimensão dos desafios para a defesa da educação como bem público. Observa-se, nesse processo, a ameaça na qualidade da educação, que perpassa todas as instâncias, desde a formação até a prestação de serviço no mercado de trabalho.

O investimento na área da saúde, na perspectiva intersetorial e interdisciplinar, tem sido ressaltado igualmente pela Organização Pan-Americana de Saúde (2006) e pela Organização Mundial de Saúde (2006), visando compartilhar problemas e soluções e para dar respostas às necessidades de saúde e à participação ativa dos sujeitos envolvidos na saúde. Deste modo, conhecer e trocar experiências entre os países é um subsídio importante para a conquista do direito universal à saúde, na medida em que essa ação pode fornecer elementos para o debate e propostas alternativas sobre a formação profissional e a educação permanente dos trabalhadores da saúde. Destacase que a implementação dos serviços de saúde é um desafio não apenas local e regional, mas mundial, no esforço de promover a melhoria da qualidade de vida e de saúde das populações.

Essa motivação leva a refletir alguns aspectos ressaltados pela OMS (2007, p.XVII), que chama a atenção da comunidade mundial moderna, pois “ "...] tem recursos financeiros e tecnologias suficientes para lidar com a maioria desses desafios em saúde [...]", e alerta que esse desafio requer vontade e compromisso político e para

utilizar conhecimentos e construir sistemas de saúde robustos para o tratamento e a prevenção de doenças e a promoção da saúde da população. O desenvolvimento de trabalhadores de saúde capazes, motivados e apoiados é essencial para superar as dificuldades que impedem o alcance de objetivos de saúde nacionais e globais. 
O Relatório Mundial de Saúde 2006 (OMS, 2007, p.xxix) com o tema "Trabalhando juntos pela saúde", apresenta uma avaliação da força de trabalho global de saúde e propostas de cooperação entre as sociedades e seus recursos - humanos, financeiros, tecnológicos, científicos -, uma análise detalhada da importância do investimento nos trabalhadores de saúde como um dos desafios prioritários para o século XXI, e enfoca que "[...] o desenvolvimento da força de trabalho é um processo contínuo que está sempre aberto a melhorias".

Nessa referência, considera que os trabalhadores de saúde são todas as "pessoas fundamentalmente engajadas em ações com o objetivo primordial de intensificar a saúde [...]. Esse significado é derivado da definição de sistema de saúde definido pela OMS, que compreende as atividades cujo objetivo principal é a melhoria da saúde" (OMS, 2007, p.2). Nota-se que essa definição tem sido construída, e não está concluída, levando-se em consideração as diferentes concepções e culturas dos países para trabalhadores de saúde.

De acordo com o Relatório-2006, a OMS (2007) construiu um perfil global baseado em pesquisas e análises, para conhecer a força de trabalho mundial na área da saúde, ou melhor, conhecer quem são esses trabalhadores de saúde. Estima-se que "existam no mundo um total de 59,2 milhões de trabalhadores de saúde assalariados trabalhando em período integral”. Esse perfil mostra uma distribuição desigual desses trabalhadores entre os países e dentro deles (OMS, 2007, p.2).

Esses trabalhadores são encontrados predominantemente em áreas mais ricas, onde as necessidades de saúde são menos severas. Seus números permanecem lamentavelmente insuficientes para atender as necessidades de saúde, com o déficit total estando na ordem dos 4,3 milhões de trabalhadores. O perfil também mostra o quanto se desconhece. Informações sobre composição da equipe, faixa etária, fontes de renda, localização geográfica e outras características que são importantes para o desenvolvimento de políticas, estão longe de estar completas. Uma razão para isso é a variação entre os países em suas definições para categorizar os trabalhadores de saúde, o que torna difícil assegurar que as mesmas pessoas estão sendo incluídas como parte da força de trabalho em saúde em cenários diferentes. A outra razão é simplesmente a ausência de dados.

Há predominância desses trabalhadores no setor público: cerca de dois terços, e um terço no setor privado. As condições de trabalho nos sistemas 
de saúde do mundo, nos dois setores, indicam que os trabalhadores de saúde estão sofrendo com as condições de trabalho afetadas pela pobreza. Condições inseguras no local de trabalho, políticas e práticas insuficientes para o desenvolvimento de recursos humanos (estruturas de carreira, condições de trabalho e remuneração baixa), mercados de trabalho privado imperfeitos, ausência de dinheiro público, impedimentos burocráticos e interferência política produzem esse paradoxo de carências em meio ao talento subutilizado (OMS, 2007).

Além desses problemas, as análises mostram a formação imprópria ou inadequada dos trabalhadores de saúde (OMS, 2007, p.7), "[...] com currículos que não se baseiam nas necessidades de saúde", pouco acesso "a recursos de informações e conhecimento" e poucas habilidades adequadas ao trabalho na saúde. Mostram ainda: "Baixa moral e motivação. [...] Alta taxa de perda dos trabalhadores de saúde, causada pela morte provocada pelas próprias doenças que eles trabalham para curar, ou por causa da migração".

A falta de capacidade de planejamento e gestão, tanto para a preparação dos trabalhadores de saúde quanto para o desenvolvimento de competências, representa a necessidade de investimentos estratégicos em educação e práticas eficazes e éticas. Dessa perspectiva, a OMS (2007, p.43) alerta que a prevalência crescente de doenças crônicas, focos de doenças imprevistas" e situações mundiais que exigem "respostas imediatas e eficazes a desastres e focos tão variados quanto terremotos, furacões, enchentes, [... ] requer uma força de trabalho ágil com habilidades altamente especializadas, incluindo a capacidade de conduzir diagnósticos rápidos, vigilância [...]”.

Portanto, a preparação dos trabalhadores da saúde "deve ir além da identificação de habilidades. As instituições e os programas de formação devem designar onde essas habilidades são geradas e atualizadas" (OMS, 2007, p.43).

Nos últimos anos, o foco tradicional sobre os cuidados centrados na doença, no atendimento hospitalar e por subespecialistas, segundo a OMS (2007), deu passagem a novos paradigmas voltados para os cuidados centrados na pessoa e desenvolvidos na comunidade, valorizando a corresponsabilidade. Enfim, o século XXI apresenta novos desafios e demanda respostas eficazes e até imediatas aos problemas atuais, exigindo o reconhecimento ao imperativo de novas abordagens e mudanças no âmbito da formação. 
As estratégias apresentadas para fortalecer esse processo podem ser elencadas como: a) aumentar a construção de instituições de educação e o número de instituições públicas, especialmente de faculdades de saúde pública, ${ }^{6}$ com atenção para o conteúdo curricular quanto aos métodos pedagógicos, visando à mudança da formação profissional do "sabe tudo" para o "sabe como"; b) a garantia da qualidade da educação, apontando o crescimento do setor privado na educação e a necessidade da intervenção do Estado no credenciamento e regulamentação profissional para assegurar qualidade, capacidade de resposta e prática ética; c) a revitalização das capacidades de recrutamento para intermediar as demandas e as necessidades de saúde pública (OMS, 2007).

Entre as estratégias citadas, destaca-se que o direcionamento dos processos educacionais para o aprendizado baseado em problemas, ${ }^{7}$ com maior ênfase no "saber como" do que no "saber tudo", tem resultado na satisfação dos sujeitos envolvidos e em experiências positivas. As avaliações desse método de aprendizado baseado em problemas, valorizado pela OMS (2007, p.49), "[...] promove a competência ensinando os estudantes como integrar e aplicar conhecimentos em cenários de prática, aprender com modelos de comportamento e experimentar abordagens interdisciplinares e em equipe à prestação de serviços de saúde".

Outro aspecto importante da aprendizagem baseada em problemas, vencendo o desafio de estimular os trabalhadores de saúde ao aprendizado permanente e a desenvolver competências para o trabalho, é que envolve a integração nas habilidades nas atitudes e nos comportamentos dos profissionais

6 O quadro mundial de estabelecimentos educacionais que formam trabalhadores de saúde, por região da OMS (2007, p.44), demonstra que "se dedicam à formação de médicos e pessoal de enfermagem: 1.691 e 5.492, respectivamente, em contraste com 914 faculdades de farmácia, 773 faculdades de odontologia e 375 faculdades de saúde pública”. Em relação às Faculdades de Saúde Pública, nessas regiões da OMS, as pesquisas apresentam menos faculdades no Mediterrâneo Oriental e no Sudeste da Ásia, ou seja: África - 50, Américas - 112, Sudeste da Ásia - 12, Europa - 81, Mediterrâneo oriental - 8 e, Pacífico ocidental - 112. Sendo um total de apenas 375 Faculdades de Saúde Pública no mundo.

7 O aprendizado baseado em problemas se desenvolve por meio: “[...] da identificação do problema; da exploração do conhecimento preexistente; da geração de hipóteses e mecanismos possíveis; da identificação de questões e objetivos de aprendizado; do autoestudo e do aprendizado em grupo; da reavaliação e da aplicação de novos conhecimentos ao problema; da avaliação e da reflexão sobre o aprendizado" (OMS, 2007, p.57). 
de saúde. Assim, essa aprendizagem tem por finalidade desenvolver o pensamento crítico e habilidades para a solução de problemas, ser interdisciplinar e multidimensional, desenvolver parcerias de aprendizado entre os envolvidos e estimular a educação experimental, incluindo a reflexão crítica, a observação e o aprendizado com base na prática (OMS, 2007). ${ }^{8}$

Destaca-se que esse aprendizado, entre outras vantagens, estimula a integração do ensino e prática, a troca de experiências com os sujeitos/usuários e ressalta e participa do atendimento às necessidades de saúde. É uma formação que "provoca mudança do comportamento do trabalhador quando é interativo, baseado em problemas da vida real e associados a um apoio contínuo" (OMS, 2007, p.105). O uso de abordagens simples, de baixo custo, associadas ao desenvolvimento profissional permanente, que vai além do treinamento, tem resultado em melhorias no quadro de saúde-doença. Aconselha a OMS (2007, p.105):

Para ilustrar esse fato, embora o uso de sais de reidratação oral para diarreia infantil tenha aumentado nos anos 1980 e 1990, após mais de 2 mil cursos de formação na gestão e supervisão de casos de 1988 a 1993 em mais de 120 países, a porcentagem média de crianças reidratadas corretamente pelos trabalhadores de saúde (dados de 22 pesquisas) foi de apenas $20 \%$.

Essa situação demonstra o significado mais abrangente da formação profissional permanente, e, se estiver associada ao trabalho em equipe, resulta em benefícios, que incluem o aumento do bem-estar dos trabalhadores de saúde e uma melhor qualidade na prestação de cuidados, como observado pelas pesquisas mundiais (OMS, 2007). São evidências a serem consideradas

8 Um exemplo do uso desse método citado no Relatório é: "Programa de Parceiros em Clínica da Faculdade de Farmácia da Universidade Estadual de Ohio proporciona um ambiente de aprendizado ativo, oferece um modelo focado no paciente baseado nos princípios de cuidados farmacêuticos e é uma arena para a pesquisa aplicada em prática de farmácia. A integração com a prática clínica é empreendida logo no início e mantida, sendo os estudantes ligados a pacientes específicos - chamados "pacientes longitudinais" - a quem eles acompanham por todos os estágios da prestação de cuidados. O programa oferece vários serviços e desenvolvimento de competências, incluindo controle da anticoagulação, autocontrole do diabetes, controle de colesterol, educação para hepatite $\mathrm{C}$, consultas para a prescrição de produtos feitos com ervas e suplementos dietéticos, controle de medicação, abandono do tabagismo e bemestar" (OMS, 2007, p.49). 
pelas organizações e instituições, já que as informações obtidas por meio das pesquisas, das observações e análises traduzem as necessidades de saúde e indicam mudanças em vários níveis.

Observa-se, a partir das informações apresentadas pela OMS (2007), que a saúde é um setor influenciado e interessado cada vez mais no mercado privado mundial, tanto no que se refere à atenção à saúde quanto à formação profissional e ao mercado de trabalho. ${ }^{9} \mathrm{Um}$ aspecto diretamente relacionado a essa situação é o rápido crescimento da educação particular de profissionais de saúde, que forma um perfil para atender ao mercado de trabalho, o qual, muitas vezes, escapa das demandas e necessidades de saúde pública.

De uma maneira geral, a OMS (2007, p.58) orienta estratégias nacionais para "agir agora, antever o futuro e adquirir capacidades críticas", mas que, por si só, são "insuficientes para lidar com as realidades dos desafios da força de trabalho de saúde hoje e no futuro". Devem, portanto, ser complementadas pela "solidariedade global em pelo menos três fontes: conhecimento e aprendizado; acordos e cooperação; e capacidade de resposta às crises da força de trabalho".

Essa realidade apresenta um caminho mundial em que o conhecimento e o aprendizado, ao servir para transformar as ações de saúde e envolver universidades, ministérios de saúde, associações profissionais, prestadores de serviços, sindicatos e representantes de usuários, podem ajudar a eleger as melhores práticas e habilidades visando à solução de problemas como compromisso político, ético e coletivo.

9 Os dados provenientes do mundo todo são indicativos da tendência das universidades particulares que oferecem formação para profissionais de saúde estão aumentando rapidamente em países de renda baixa e média, refletindo um fenômeno mais amplo de aumento da prestação de serviços particulares de educação vocacional e técnica (OMS, 2007, p.58). 


\section{3 \\ As Políticas Públicas de Saúde}

\section{A trajetória das Políticas Públicas de Saúde}

A questão do funcionamento do SUS. Onde está o problema? É um problema da gestão, do gerenciamento, da fiscalização, do serviço também, que é outra área que está muito deficiente. Falta gerenciamento. As pessoas não têm o hábito de questionar, de ir atrás dos interesses relacionados à saúde. Por "n" questões, por uma questão mesmo de despreparo. Nós não fomos educados para tal [...] Então, isso traz dificuldade. [...] É, quando se prioriza ações voltadas para a alta e média complexidade em detrimento daquelas de base mesmo. De atenção primária. Prioriza o curativo, o hospitalar. [...] Com certeza, tem muito, muito disso ainda. Mas estamos caminhando pra isso. Eu acredito que sim. (S1)

Um dos problemas que eu vejo é que é novo, apesar de estar fazendo vinte anos, eu acho que ainda é um processo que as pessoas não estão acostumadas a usar. Por exemplo, hoje eu vejo como um grande problema no País, como tudo na saúde, na educação e todas as coisas, é que as pessoas não sabem lidar com a democracia, com a responsabilidade da discussão, do diálogo, do trabalho coletivo. Eu acredito que as pessoas não têm, elas não sabem como, vamos dizer assim, lidar com esse processo democrático. Então, por exemplo, elas não sabem atuar como cidadão, cobrar seus direitos, seus deveres, elas não sabem impor a vontade delas, não têm um controle social, que eu acho que é uma das características bacanas também do Sistema, queé o controle social. Então, quando você trabalha com a municipalização e deixa o Conselho de Saúde administrar os recursos de acordo com as prioridades do município, você tá fazendo, exercendo a democracia, que é presenciar um usuário discutindo com o gestor onde ele vai aplicar melhor. Só que, infelizmente, falta ainda o conhecimento, 
ou sei lá, uma cultura de exercer esse papel. Então, os nossos próprios cidadãos, usuários ou trabalhadores não sabem exercer esse papel democrático [...]. Saber exercer essa discussão. Esse controle social ainda está muito no começo. (S2)

Eu acho que tudo é bom, entendeu? É, tudo, todo mundo tem direito. Antes não era assim. Eu te falei, a demanda que fica, que eles não conseguem alcançar realmente, tudo que eles pretendem, e talvez, não sei por quê, se vem lá de cima. [...] Tem dificuldade dos usuários ter acesso às especialidades, às cirurgias. Então é nesse aspecto que tá complicado. É que eu acho mais difícil. [...] Porque aqui, por exemplo, como é municipalizado, a gente não tem tanto problema, né? Porque o prefeito, realmente ele assume, sabe? Não falta nada. [...] Aqui ele não deixa faltar nada. Não falta médico, funcionário, remédio, sabe? [...] Tem tudo nas unidades (atenção básica). [...] A dificuldade, bom é de encaminhamento, as especialidades e cirurgia, cirurgia seletiva. E as especialidades, cardiologia, neuro, ortopedia, otorrino. Não sei por que não dá certo. (S3)

Avaliar? O SUS? É difícil. Rever as políticas? Será que seria o caminho? Porque se o SUS é uma política boa, você tem que rever aquilo ali que tá pronto? Talvez não. Direcionar melhor a verba? Será que seria o caminho? [...] Não dá certo, na hora da divisão de recurso. Será que seria isso? [...] Ah, essa é uma questão. Seria deixar mais para o município. [...] Municipalizou mas não dividiu a responsabilidade. Então, o município teria que entrar com mais? Eu acho que assim, são várias as coisas que a gente deveria repensar. A política em si, será que deveria ser revista? Seria o momento? São vinte anos aí de SUS, né? Acho que ficou muito tempo pra gente falar que tem que ser revisto. Não sei. Naquela época era uma realidade, e hoje? Onde que tá o problema? Será que é lá em cima? Porque o Brasil eu falo que é um país muito rico, pena que tem os desvios. Se não houvesse tanto desvio, a gente teria mais condições. [...] Não só de saúde, mas de educação, na área social. [...] Ainda fica a desejar, né? Melhorando essa parte social, a parte de financiamento. Mas eu acho que é trabalho de formiguinha, não é? (S4)

A análise das políticas públicas de saúde pauta-se em uma perspectiva que considera a importância de compreender a concepção de saúde construída pela sociedade brasileira, historicamente marcada pelo modelo curativo, centrado na assistência médica e nas especialidades, tendo como referência o hospital. Observa-se nas experiências relatadas que as transformações produzidas pelo conhecimento humano, científico e tecnológico, saberes populares, experiências práticas exitosas, construídos acerca da importância dos 
cuidados primários de saúde, da prevenção e promoção da saúde, entretanto, não foram suficientes para ruptura desse modelo biologicista e de mercado.

Os trabalhadores da saúde entrevistados identificam no cotidiano do Sistema Único de Saúde (SUS) os desafios para o direito universal e integral à saúde. Exemplificam os limites e os problemas decorrentes da falta de gerenciamento e de fiscalização, da burocracia, entre outros, que comprometem a implementação e descentralização da política pública de saúde, mas, principalmente, impedem o exercício da democracia e da cidadania na saúde.

Deste modo, a compreensão das políticas sociais e da política de saúde brasileira na atualidade está relacionada com o formato que vem adquirindo desde suas origens. $\mathrm{O}$ acesso à assistência à saúde como um direito reconhecido das classes assalariadas foi sempre vinculado ao direcionamento da política econômica.

Desta perspectiva, é interessante resgatar os estudos de Behring \& Boschetti (2006) a respeito do caráter histórico-estrutural das políticas sociais, que procuram desvendar suas características e determinações - econômicas, sociais, políticas, culturais - e apontar alguns momentos que influenciaram e determinaram a própria concepção de saúde que se tem hoje. Essa análise procura, ao mesmo tempo, conhecer o papel do Estado e os interesses envolvidos na regulamentação e desenvolvimento das políticas públicas e os caminhos adotados em sua efetivação, para, desta maneira, desvendar o significado real da política de saúde para os sujeitos envolvidos e compreender a articulação dessas situações sobre a vida humana em que predomina o econômico.

É esse pensamento comum, construído historicamente, que orienta a ideia de inviabilidade, ineficácia e até de descrença em torno das políticas públicas de saúde, que se pretende decompor na análise desta realidade social em que "[...] se inserem as políticas sociais como processos inscritos na sociedade burguesa” (Behring \& Boschetti, 2006, p.40). Para as autoras, a política social é uma conquista civilizatória. Mesmo não sendo a via de solução da desigualdade, que é intrínseca a este mundo baseado na exploração do capital sobre o trabalho, na escassez e na miséria, exige uma luta em seu favor como instrumento para minimizar as desigualdades e possibilitar a inclusão social.

A perspectiva de totalidade busca, portanto, apreender os movimentos, as contradições, os conflitos e como esses fenômenos se manifestam no coti- 
diano e na vida humana, que, segundo Kosik (2002), de maneira imediata e regular penetram na consciência e adquirem uma aparência natural e comum. Portanto, considerar essas dimensões - histórica, econômica, política e cultural como elementos articulados, o que mostra a importância de identificar, sem o intuito de esgotar aqui as possibilidades de explicação, alguns dos eixos estruturantes que concorreram para a formação da política de saúde pública.

Segundo Nunes (1985), de 1880 a 1930, o Brasil está permeado pela investigação bacteriológica e parasitológica relacionada à estrutura social da época, voltada à produção agroexportadora e às doenças tropicais. Porém, o advento da bacteriologia sobrepõe-se aos determinantes sociais das doenças. Lourenço (2004) avalia que esse período no Brasil refere-se ainda à fase de organização da estrutura dos serviços de saúde no âmbito do Estado, com ênfase na prevalência do conhecimento/saber científico como um imperativo para a imposição de medidas. Estas deveriam ser seguidas e se expressaram como via para o fortalecimento e reconhecimento da autoridade e da capacidade dos órgãos que estavam sendo criados.

Os serviços eram estabelecidos em uma relação vertical, com imposição de normas e segregação social, em que os técnicos tinham o saber científico. Desconsideravam o conhecimento popular, principalmente dos pobres e dos negros, considerados como incapazes de compreender as causas das doenças ou de ter direitos. O Código Sanitário de 1918 inicia campanhas de educação em saúde voltadas para a questão do saneamento (sanear é a grande questão nacional) e do controle de endemias (Vasconcelos, 1997). Mas são ações pontuais e fragmentadas.

A criação de Caixas de Aposentadoria e Pensão (CAPs), pela lei Eloy Chaves, em 1923, institui a obrigatoriedade de seguro social e do financiamento vinculado à contribuição do empregado e do empregador. As CAPs eram organizações privadas formadas por empresas e, posteriormente, por setor de atividade econômica, que reconhecia os direitos previdenciários e trabalhistas para algumas categorias de trabalhadores, como os ferroviários e marítimos, dentre outros. Observa-se que essas categorias eram estratégicas para a economia do País e diretamente ligadas nesse momento ao processo de produção e reprodução de mercadorias, uma economia formada basicamente na monocultura do café voltada para a exportação (Cohn, 1997; Behring \& Boschetti, 2006). 
O sistema público de previdência social brasileira começou com os Institutos de Aposentadorias e Pensões (IAPs), que se expandem na década de 1930 , cobrindo as categorias estratégicas de trabalhadores pela lógica contributiva do seguro, ou seja, dos trabalhadores, dos empresários e do Estado. O primeiro IAP foi criado em 1933, dos marítimos, e com isso as CAPs foram paulatinamente se extinguindo, voltadas mais para a acumulação de reservas financeiras do que para a prestação de serviços, como aponta Bravo (2000). O modelo getulista (1930-1945) de proteção social se definia como fragmentado em categorias, limitado e desigual na implementação dos benefícios, como estratégia de controle das classes trabalhadoras.

A intervenção do Estado na saúde inicia em 1930, quando foi criado o Ministério da Educação e Saúde e organizada uma política nacional de saúde a partir de dois eixos: da saúde pública e da medicina previdenciária ligada aos IAPs e suas categorias correspondentes. A saúde pública foi desenvolvida por meio de campanhas sanitárias, coordenadas pelo Departamento Nacional de Saúde, criado em 1937, onde há, ao mesmo tempo, o desenvolvimento da saúde privada e filantrópica, referente ao atendimento médicohospitalar. Nesse período de introdução da política social brasileira, a relação do Estado com a sociedade civil é assinalada por uma "[...] expansão fragmentada e seletiva das políticas sociais, que segue até 1964" (Behring \& Boschetti, 2006, p.108).

Os recursos arrecadados pela previdência social, desde o início, eram aplicados pelo governo no financiamento da industrialização do País, sendo que esse modelo de proteção social definia-se como fragmentado em categorias, limitado e desigual na implementação dos benefícios, em troca de um controle social das classes trabalhadoras. A ação do Estado na área da saúde divide-se, claramente, de um lado, a saúde pública de caráter preventivo e coletivo, conduzida por meio de campanhas, voltada para a luta contra as epidemias e desenvolvida com uma preocupação mais social; e de outro, a assistência médica de caráter curativo e individual, conduzida aos trabalhadores contribuintes por meio da ação da previdência social.

A assistência médica segue a lógica da privatização dos serviços, que se acentuam, na década de 1930, "[...] na compra de serviços privados de saúde a possibilidade de maior acesso dos seus segurados" (Behring \& Boschetti, 2006, p.228). E a assistência médica para a população empobrecida, que não 
dispunha de recursos como o CAPs ou IAPS, era prestada pelo atendimento de caridade e filantrópico, mantido pela igreja.

A organização dos serviços públicos de saúde no âmbito do Estado tem ênfase na prevalência do conhecimento científico, como a imposição de medidas que expressavam o fortalecimento da autoridade e da capacidade dos órgãos que estavam sendo criados. A questão da saúde era tratada como uma questão de polícia, e os serviços eram estabelecidos em uma relação vertical, com imposição de normas e segregação social, em que os técnicos tinham o saber científico e desconsideravam o conhecimento popular, considerado incapaz de compreender as causas das doenças ou de ter direitos.

O conjunto de novos problemas desencadeados pelo processo de industrialização, da precariedade das condições de vida, trabalho e habitação leva o Estado a perceber a necessidade de implementar medidas ou respostas para "melhorar" a qualidade de vida da população trabalhadora, visando melhor produtividade e utilidade na acumulação de riquezas (Pereira, 2000). Essa característica do Estado regulador tem por finalidade o desenvolvimento do capitalismo e, ao mesmo tempo, intervém nas desigualdades sociais para evitar conflitos e não desestabilizar a ordem social e política. Deste modo, regula e redistribui recursos econômicos e atende a alguns interesses das classes e grupos sociais. A existência das políticas sociais é, portanto, um fenômeno associado à constituição da sociedade burguesa no seu modo capitalista de produzir e (se) reproduzir.

Segundo Abreu (1999), o Estado regulador tem por finalidade e função o desenvolvimento capitalista da nação, ao mesmo tempo em que intervém nas desigualdades sociais para que não se tornem lutas políticas desestabilizadoras da ordem social e política. No Brasil, as estratégias regulacionistas e desenvolvimentistas foram implementadas por uma elite conservadora, na burocracia estatal, de cima para baixo, e sem a participação da cidadania e das classes trabalhadoras, facilitadas por altas taxas de crescimento econômico, rápida industrialização, geração de milhões de empregos e uma rede burocrático-corporativa de controle das classes e de proteção social. Inclui-se nessa análise a ausência de uma cultura de bem-estar social, a concentração de renda, de propriedade e de recursos do poder, sem a universalização dos direitos políticos e sociais da cidadania, sem um Welfare State democrático.

A política social e trabalhista, bem como o desenvolvimento dos serviços públicos da saúde, da educação e da habitação, começam a ser implantados 
a partir da década de 1930 até meados de 1940, quando é estruturada a legislação trabalhista, com vistas a regular os conflitos na linha do consenso entre as classes sociais. A saúde, vinculada ao Ministério da Educação, garantiu a proliferação dos órgãos e ações de saúde pelo Estado com a criação do Departamento Nacional de Saúde, em 1937.

Por outro lado, a organização do sistema previdenciário estruturado a partir de categorias profissionais, mantendo benefícios, inclusive assistência à saúde proporcional à contribuição, acabou por cortar as ações mantidas pelo Estado, restringindo às medidas campanhistas e também aquelas garantidas por meio da contribuição compulsória. As ações educativas em saúde limitavam-se a alguns programas, em que a prioridade era o combate às doenças infecciosas e parasitárias, e o enfoque era nas categorias ligadas à exportação e ao comércio (ferroviários, marítimos, bancários), relacionadas às atividades fundamentais para o desenvolvimento do capitalismo no Brasil.

A partir da introdução das políticas keynesianas, o setor de saúde e outros passaram a ocupar um papel importante na geração de emprego e renda e, sobretudo, na possibilidade de diminuir os conflitos sociais inerentes ao sistema capitalista, ao cuidar da mão de obra trabalhadora. Novas políticas sociais, segundo Massako (1994), foram implementadas a partir da segunda República (1930-1945), quando novas demandas são impostas pelo crescimento da economia industrial e pelo temor do avanço do comunismo, marcadas por greves e lutas trabalhistas por melhores salários. A aglomeração urbana não planejada também serviu para dar visibilidade às doenças, levando médicos e leigos a se organizar em Associações e Ligas. Outros aspectos estariam relacionados ao incentivo à saúde hospitalar de natureza privada, representada também pela construção de grandes hospitais, como o Hospital das Clínicas (HC) de São Paulo e a criação do Serviço Especial de Saúde Pública (Sesp), por meio de convênio com órgãos americanos e patrocínio da Fundação Rockefeller.

Garcia (1985), ao falar do reaparecimento da medicina social ${ }^{1}$, na década de 1940, lembra que até a década de 1970, tal medicina não conseguiu ex-

11948 é o ano de nascimento da medicina social. O conceito apesar de ser utilizado de forma ambígua, tratava de assinalar que a doença estava relacionada com os "problemas sociais" e que o Estado deveria intervir ativamente na solução dos problemas de saúde (Garcia, 1985, p.22). 
pressão en função do ambiente político agressivo ao que pudesse ser considerado social e, portanto, próximo ao socialismo. Situa que Escolas de Medicina nos Estados Unidos passam a usar "[...] o termo 'Medicina Preventiva' que incluía o tema das ciências sociais. Antropólogos e sociólogos são os primeiros cientistas sociais a participarem nesta nova disciplina, começando a realizar pesquisas no campo da saúde" (Garcia, 1985, p.22). Posteriormente, na década de 1950, a Organização Pan-Americana de Saúde (Opas) propõe como acréscimo para a formação do médico a medicina preventiva e social. Garcia (1985, p.23) destaca que a relação ensino-aprendizagem da medicina "[...] latino-americana era avaliada como atrasada cientificamente, desintegrada da prevenção, indisciplinada metodologicamente e anacrônica”. Esse modelo de saúde, com ênfase na assistência curativa, é confirmado no estudo de Nunes (1985, p.34), quando se refere ao período de 1930 a 1950 e aponta "[...] a investigação básica conectada com o crescimento hospitalar impulsionado pela industrialização”.

Após a Segunda Guerra Mundial, fatores condicionantes, elucidados a partir da hegemonia norte-americana e pela divisão do mundo em dois polos - capitalista e socialista - contribuem substancialmente para a mudança da relação entre Estado e sociedade. A busca de respostas às demandas sociais engendradas pelo próprio sistema implicou a democratização e implementação da política social sustentada pelo Estado de Bem-Estar Social efetivada nos países desenvolvidos. No contexto brasileiro, o Estado demonstra sua influência a partir de uma política desenvolvimentista e de planejamento de sua intervenção. A saúde foi considerada como fator econômico junto a outras políticas, correlacionada ao controle social subordinador e ao bom andamento da economia.

A partir do Estado Novo (1945-1960), mais precisamente em meados de 1950, houve a criação dos centros sociais rurais, com a preocupação do controle das endemias rurais, tais como a erradicação da malária e da doença de Chagas. Essas ações seguiam a filosofia de desenvolvimento de comunidade, e entendia-se, na época, a educação em saúde como a introdução de "novas técnicas de difusão de informação e convencimento da população, vista como passiva e incapaz de iniciativas próprias”, para Vasconcelos (1997, p.43).

A expansão e consolidação da política social no período pós-crise de 19291932, sobretudo, foi abalada pelos acontecimentos mundiais das três pri- 
meiras décadas do século XX. Após a Segunda Guerra Mundial, quando se adentrou na fase madura do capitalismo, caracterizada por um intenso processo de monopolização do capital, pela intervenção do Estado na economia e no livre movimento do mercado, constituindo-se oligopólios privados (empresas) e estatais (empresas e fundações públicas).

As condições históricas determinadas a partir dos anos 1930, com a expansão da urbanização da população, o aumento das desigualdades regionais e com uma industrialização significativa, iniciam no País uma forte expansão do processo de modernização, "por meio de políticas de industrialização induzidas pelo Estado, e que de 1945 a 1960 assume o perfil do que se convencionou denominar modelo de substituição de importações” (Cohn, 1997, p.228). A principal expressão do governo (Juscelino Kubitschek, o Plano de Metas - crescer cinquenta anos em cinco), nesse período, é marcada por intensas mudanças econômicas, políticas e sociais, e tem como principais características a melhor organização do movimento operário e popular, a intensificação da luta de classes, o enfraquecimento ou a fragmentação da burguesia, onde crescem as tensões no campo e também entre as camadas médias urbanas.

As políticas sociais, desta maneira, ganham uma nova configuração a partir dos anos 1930, momento em que o capitalismo enfrenta uma de suas maiores crises econômicas, com queda de produção, desemprego, falência de bancos e empresas. No Brasil, as políticas sociais emergem no final da República Velha, na década de 1920, e ganham destaque nos anos 1930 no governo de Getulio Vargas. Com forte apelo populista, as medidas visavam a combater greves e movimentos sociais, enquanto contemplavam algumas categorias de trabalhadores, sendo injustas e desiguais.

De 1930 a 1945, na segunda República, foram implementadas novas políticas sociais para responder às demandas emergentes impostas pelo crescimento da economia industrial e pelo temor do avanço do comunismo, marcadas por greves e lutas trabalhistas e por melhores salários (Massako, 1984). Nesse período, com Getulio Vargas no poder, há um direcionamento da política no sentido de transformar as relações entre Estado e sociedade, visando beneficiar a industrialização do País. A política trabalhista do governo buscava, ao mesmo tempo, controlar as greves e os movimentos operários e estabelecer um sistema de seguro social. Explicitava abertamente substituir a luta de classes pela colaboração de classes (Faleiros, 2000). 
No contexto brasileiro, o Estado demonstra sua influência a partir de uma política desenvolvimentista e de planejamento de sua intervenção. A saúde foi considerada como fator econômico junto a outras políticas, correlacionada ao controle social subordinador e ao bom andamento da economia. A partir do Estado Novo (1945-1960), mais precisamente em meados de 1950, houve a criação dos centros sociais rurais, com a preocupação do controle das endemias rurais, tais como a erradicação da malária e da doença de Chagas. Essas ações seguiam a filosofia de desenvolvimento de comunidade, e a educação em saúde na época era entendida como a introdução de "novas técnicas de difusão de informação e convencimento da população, vista como passiva e incapaz de iniciativas próprias" (Vasconcelos, 1997, p.43).

Lourenço \& Bertani (2007) analisam que o pensamento acerca da questão saúde-doença, foi representado, principalmente na década de 1950, por pesquisas marcadas pelas teorias funcionalistas e culturais, servindo à implementação de estratégias de desenvolvimento e organização de comunidade, conforme estudos de Nunes (1985). Após a Segunda Guerra Mundial, sob o domínio do positivismo sociológico, houve uma valorização do social, com maior aproximação das ciências sociais e das ciências da saúde, e estudos realizados por meio de observação direta e participante indicaram a cultura, o modo de vida, crenças e valores na relação com o processo de saúde-doença. Contudo, Nunes (1985, p.37) destaca que "[...] algumas das limitações desse enfoque microanalítico e descritivo das pequenas comunidades rurais não permitiram fazer referências sobre a realidade nacional nem sobre a organização do sistema”.

Deste modo, a ênfase no modelo de saúde individual e curativo esteve presente na realização da 1르 Conferência Nacional de Saúde, que aconteceu em 1941 e apresentou como principal preocupação a "Situação sanitária e assistencial dos Estados", discutindo essa questão e as responsabilidades nos níveis estaduais e municipais, nos serviços de saneamento básico, ações de proteção materno-infantil e campanhas contra a tuberculose e a hanseníase. Contudo, acabou destacando a necessidade da expansão do número de leitos em hospitais gerais ou sanatórios para atendimento aos tuberculosos, sendo essa indicação ratificada pela Constituição Federal de 1946, com a construção de novos hospitais para atender à tuberculose e outras doenças resultantes dos determinantes sociais de saúde (Massako, 1994). Esse enfo- 
que também esteve presente na 2 2 Conferência Nacional de Saúde, realizada em 1950, que adotou a mesma orientação da 1a CNS: focalizou a "Legislação referente à higiene e a legislação do trabalho" e procurou estabelecer estratégias para o estabelecimento de legislação referente a essas prioridades, além de assistência médica sanitária preventiva a gestantes (Fleury, 1991).

As mudanças que ocorreram no panorama internacional a partir de 1945, em função do término da Segunda Guerra Mundial, e as exigências e necessidades de aprofundamento do capitalismo foram condições gerais que influíram no conceito de saúde elaborado em 1948 junto à Organização Mundial de Saúde (OMS). Foi aqui reconhecido que a saúde não tem implicação somente física e biológica. A influência das questões sociais e econômicas tem um papel importante, e, assim, a saúde foi definida como um completo bem-estar físico, mental e social, e não simplesmente a ausência de doenças (Bravo \& Matos, 2004).

No enfoque dos aspectos biopsicossociais e multiprofissionais, relacionados à gravidade das condições de saúde da população, houve diversos desdobramentos, como o trabalho em equipe multidisciplinar, "solução racionalizadora" encontrada, que, além de suprir a falta de profissionais, permitiu "[...] ampliar a abordagem em saúde, introduzindo conteúdos preventivistas e educativos" (Bravo \& Matos, 2004, p.199). E, ainda, desenvolver programas prioritários com segmentos da população, uma vez que não havia intenção de universalizar a atenção médica e social.

O período de 1945 a 1964, portanto, foi marcado por grandes mudanças na área da saúde no País. A influência norte-americana, durante as duas Guerras Mundiais, levou o Brasil a adotar o modelo de saúde baseado em grandes hospitais, que coloca em segundo plano a rede de atenção básica postos de saúde, consultórios e ambulatórios com baixo custo. Lembrando que a estrutura e o funcionamento dos grandes hospitais atende aos interesses e às necessidades crescentes da indústria farmacêutica e de equipamentos médicos.

Outros fatores condicionantes, após a Segunda Guerra Mundial, elucidados a partir da hegemonia norte-americana e pela divisão do mundo em dois polos - capitalista e socialista -, contribuem substancialmente para a mudança da relação entre Estado e sociedade. A busca de respostas às demandas sociais engendradas pelo próprio sistema implicou a democratiza- 
ção e implementação da política social sustentada pelo Estado de Bem-Estar Social efetivado nos países desenvolvidos. Algumas propostas racionalizadoras surgem na saúde durante a década de 1950, como a criação do Serviço Especial de Saúde Pública (Sesp). Por meio de convênio com órgãos americanos, contribui para ampliar e aprofundar as ações da saúde pública, as quais predominam sobre as iniciativas ligadas à assistência médica individual.

Nesse cenário complexo, o desenvolvimento da política de saúde foi lento e marcado pela separação entre os Ministérios da Saúde e da Educação, em 1953, e pela criação de novos IAPs. A instabilidade institucional do período - o suicídio de Vargas (1954), a renúncia de Jânio Quadros (1961) e o próprio golpe militar de 1964, que depôs João Goulart, são exemplos paradigmáticos - dificultou consensos em torno de um projeto nacional, em que incluía o desenho da política social. Assim, esse período ficou marcado pela expansão lenta dos direitos, que se mantiveram ainda no formato corporativista e fragmentado.

O projeto desenvolvimentista ligado ao capital estrangeiro, em especial o capital norte-americano, sai da fase expansiva do capitalismo e começa a dar sinais de esgotamento em fins dos anos 1960, e teve consequências avassaladoras para as condições de vida e trabalho das classes trabalhadoras. O novo modelo de acumulação "[...] traz consigo um padrão de regulação social da relação capital/trabalho que associa política trabalhista, política sindical e política previdenciária" (Cohn, 1997, p.228). Esse modelo regula a extensão dos benefícios sociais a determinados setores de classes assalariadas urbanas, estabelecendo o financiamento vinculado, essencialmente, na contribuição dos empregados e dos empregadores.

Consequentemente, o processo de desenvolvimento econômico esteve associado a um conjunto de políticas sociais, tendo como eixo a previdência social. O sistema de proteção social iniciado nos anos 1930 estende-se até meados da década de 1960, com características de "cidadania regulada", conceito discutido por Wanderley Santos (1987) para se referir à garantia de acesso aos direitos sociais e trabalhistas vinculados à contribuição previdenciária, distinguindo-se do padrão universalista praticado nos países de capitalismo avançado.

A lógica da articulação da "[...] política de seguro social comandada pela necessidade de investimentos do Estado em setores básicos da economia, 
que dessem sustentação ao processo de industrialização" (Santos, 1991, p.229). Ou seja, o sistema de proteção social obedece a uma lógica eminentemente econômica, "[...] que se sobrepõe à sua dimensão de política social, seja como conquista dos trabalhadores a esses direitos sociais, seja como política compensatória das desigualdades sociais" (Cohn, 1997, p.230). Sublinha-se que, no plano previdenciário, houve a unificação dos benefícios sociais dos vários Iaps com a promulgação, em 1960, da Lei Orgânica da Previdência Social (Lops) e, posteriormente, a absorção destes pelo Instituto Nacional de Previdência Social (INPS), criado em 1966 com forte ênfase na centralização político-administrativa.

De um lado, o Ministério da Saúde responsável pela saúde pública, por ações de caráter coletivo, tem os recursos financeiros prejudicados e um orçamento decrescente no final da década de 1950. E, de outro lado, a assistência médica individual, vinculada ao sistema de proteção social (e dando cobertura apenas para a população que a ele tem acesso), expande-se e tem o mercado garantido, uma vez que os serviços produzidos pelo setor privado de saúde são comprados pelo Estado com recursos procedentes da previdência social. Além de se tornar o maior comprador de serviços privados de saúde, o Estado "[...] regula a extensão desses direitos sociais sem praticamente onerar os recursos fiscais na medida em que a principal fonte de recursos para o seguro social provém de um percentual sobre a massa salarial [...]" (Cohn, 1997, p.230).

Os problemas sanitários emergem no cenário do País e, pela primeira vez, são discutidos e analisados durante a 3를 Conferência Nacional de Saúde, que é realizada em 1963 com o tema "Descentralização na área de saúde". O diferencial dessa Conferência é o surgimento de movimentos democráticos na área da saúde que ampliam o espaço de discussão e apontam a necessidade de definir um plano nacional que abranja as três instâncias de governo - federal, estadual e municipal -, propondo ações de descentralização a partir da participação dos municípios na solução dos problemas de saúde, que, no entanto, deu continuidade ao investimento na indústria farmacêutica estatal e na medicina privada.

O contexto político brasileiro era populista, pois o governo fazia apelo a uma ideologia difusa de adesão das massas por meio do nacionalismo, desenvolvimentismo, moralismo e reformismo, o que influenciou substancialmente, durante essas décadas, o modelo de saúde com ênfase na assis- 
tência curativa e individual, caracterizado pelo crescimento do hospital impulsionado pela industrialização. Com o desenvolvimento econômico, a implementação da indústria automobilística e a abertura do País para o capital estrangeiro, bem como com o uso do dinheiro da previdência social, algumas empresas começam a construir seus próprios hospitais, surgindo a medicina de grupo - empresas com finalidade de prestar serviços médicos particulares aos empregados de outras empresas que os contratam, marcando o nascimento da assistência médica - a previdência privada.

As políticas públicas, que se expandem nessa fase, apresentavam forte centralidade administrativa, principalmente a concepção de planejamento em saúde, além de efetivar investimentos priorizando a iniciativa privada, seguindo o modelo de saúde americano. Bravo (2006, p.92) aponta que a estrutura para atendimento hospitalar já estava pronta e indicava a formação das empresas médicas: "A corporação médica ligada aos interesses capitalistas do setor era, no momento, a mais organizada e pressionava o financiamento por meio do Estado, da produção privada, defendendo claramente a privatização". As reformas e construções de hospitais com tecnologia de alto custo abriram espaço para o fortalecimento da indústria farmacêutica e de equipamentos hospitalares, representando o privilégio do setor privado, que no período militar será enfatizado pela compra de serviços médicos a terceiros.

Adianta-se que no momento que compreende os anos de 1960 a 1988, o sistema de proteção social sofre alterações significativas, mas "[...] sem romper com a lógica de período anterior”, na análise de Cohn (1997, p.230). Ao mesmo tempo em que acontece a ampliação das políticas sociais, no período do regime militar autoritário, por um processo acelerado de privatização nos setores de bens de consumo coletivo, como é o caso da saúde e da educação, a partir de meados da década de 1970, o País assiste a um movimento de vários setores da sociedade civil para a democratização da saúde.

Os anos de 1960 iniciam no Brasil uma fase difícil na área política e econômica. O País vive uma profunda crise, decorrente da política desenvolvimentista e endividamento no governo de Juscelino Kubitschek (1956-1951), que se agrava nos governos de Jânio Quadros (1961-1961) e João Goulart (1961-1964), sem o apoio político necessário para governar.

O golpe militar de 1964 instaurou a ditadura e o obscurantismo, que vai perdurar por vinte anos, e estimulou uma modernização conservadora no 
País. Na análise de Behhing \& Boschetti (2006), as razões dessa nova crise do capital têm início nos anos 1970 como uma reação da burguesia e que explicam as mudanças no campo da política social. Nesse cenário, as pressões para a reconfiguração do papel do Estado capitalista colocam uma nova condição para a implementação de políticas sociais. Problemas como a superprodução, o desemprego resultante da introdução de novas técnicas, a elevação nos preços de matéria-prima, a diminuição do comércio mundial e a inflação são elementos que influenciaram a queda da demanda global, ocasionando uma recessão profunda e estagnação do capitalismo.

O período que compreende 1964 a 1988, ano em que é aprovada a nova Constituição Federal brasileira, tem o caráter político das relações sociais determinado pela ditadura militar (1964-1985), marcado pela repressão, violência e tortura. A ditadura caracterizou-se pela negação violenta dos direitos civis e políticos e por forte censura, ausência de eleições, centralização administrativa, controle do Congresso Nacional e do poder militar no Executivo, a repressão violenta aos opositores do governo, considerados subversivos por lutarem, de forma armada ou não, pela derrubada dos sistemas autoritários, e sua substituição pelo governo democrático e/ou socialista (Faleiros, 2000). A repressão foi a estratégia utilizada pelo Estado para intimidar a população, considerada subversiva e que, segundo Faleiros (1992, p.176, destaque do autor), "[...] não se restringia apenas a militantes dos movimentos sociais, mas àqueles considerados indivíduos 'perigosos' por seu comportamento ou pensamento”. Consistia, também, “[...] na perda do trabalho (aposentadoria compulsória e demissão) e a privação dos direitos políticos por dez anos".

O País desenvolveu-se economicamente com a expansão da produtividade, a modernização da economia e a entrada do capital estrangeiro em parceria com o Estado, e pautava-se pela consolidação do capitalismo monopolista associado aos interesses transnacionais que, para Netto (2005, p.27), "[...] é definido em proveito do grande capital, fundamentalmente dos monopólios imperialistas". Esse modelo garantiu o desenvolvimento dependente, associado a uma estrutura de poder, o que significou, nas palavras do autor, a "modernização conservadora" (Netto, 2005, p.28), que consagrava os interesses do monopólio com favorecimento ao capital estrangeiro e aos grandes grupos nativos, induzindo à concentração e centralização do capital. 
A política adotada pela ditadura militar agrava a crise salarial, leva a classe trabalhadora à miséria, aumenta o êxodo rural e, consequentemente, a urbanização acelerada e sem planejamento compromete as condições de vida da população e aumenta as doenças e a mortalidade infantil. Permitiu uma deteriorização nas condições de saúde da população, tanto pelo aumento da miséria nas cidades quanto pela mudança de ênfase dos investimentos em saúde e diminuição dos investimentos e recursos, sucateando os serviços de saúde, e os programas de saneamento são abandonados.

A unificação do sistema previdenciário em uma estrutura única, em 1966, o Instituto Nacional de Previdência Social (INPS), vai concentrar todas as contribuições previdenciárias do País, incluindo trabalhadores da indústria, do comércio e dos serviços, e vai gerar, inclusive, as aposentadorias, pensões e assistência médica de todos os trabalhadores do País. Em 1977, uma reforma administrativa criou o Sistema Nacional de Assistência e Previdência Social (Simpas), que compreendia o INPS, o Instituto Nacional de Assistência Médica e o Instituto Nacional de Administração da Previdência Social.

Com essa medida, o governo federal, por meio do INPS, criou linhas de financiamento a fundo perdido para a iniciativa privada construir hospitais particulares, visando ampliar o número de leitos hospitalares, mostrando a intenção de atender a todos os trabalhadores inscritos na previdência social. E, além disso, anunciou a extensão da previdência social aos trabalhadores rurais, que passam a ter direito a assistência médica e aposentadoria.

Ao analisar as características da política social na ditadura militar, Bravo (2006, p.95) reflete que a partir dos anos 1970 houve uma combinação de "repressão e assistência", visto que o modelo chamado "Milagre Econômico", crescimento econômico provocado pela disponibilidade de capital externo ocorrida entre os anos 1968-1974 por determinação dos governos militares e que provocou no País, nas décadas seguintes, a aceleração da expansão industrial, demonstrou sinais de fragilidade, em uma conjuntura de crise econômica e de deflagração do processo de organização e articulação dos movimentos sociais, sindicais e populares.

Faleiros (2000) reflete as características da política social na ditadura militar, no contexto de perda das liberdades democráticas, de censura, prisão e tortura, o bloco militar-tecnocrático-empresarial buscou adesão e legitimidade por meio da expansão e modernização de políticas sociais. O Estado, na busca de conter os conflitos sociais e superar a crise, implementou 
políticas sociais abrangentes, como a ampliação da cobertura previdenciária. Dessa forma, a previdência social conheceu, nesse período, sua maior expansão em números de leitos disponíveis, com cobertura da massa de recursos arrecadados.

Nessa associação entre previdência, assistência e saúde, o governo militar estimulou as políticas públicas como estratégia de busca de legitimidade, abrindo espaço para a saúde, a previdência e a educação privadas, reproduzindo nas políticas sociais as tendências da nova política econômica implementada. A medicalização da vida social foi imposta, tanto na saúde pública quanto na previdência social, e os programas de saúde desenvolveram-se com base no privilegiamento do setor privado.

O governo primou pelo investimento nos procedimentos de alta complexidade e, portanto, de alto custo. Reforçou, do mesmo modo, o investimento na medicina privada, por meio de convênios com hospitais, clínicas e serviços particulares, e desprestigiou visivelmente os serviços públicos, dando vulto ao capital industrial da saúde privada. Além disso, favoreceu o modelo de saúde curativa e especializada. A ação estava voltada para os hospitais e ambulatórios. Embora os centros de saúde tenham sido criados desde meados da década de 1920, não foram valorizados para o desenvolvimento de ações básicas de saúde (Bravo \& Matos, 2002).

A área da saúde foi profundamente atingida, com ênfase no modelo de atenção curativo, individual e especializado, o incentivo à indústria de medicamentos e equipamentos médico-hospitalares, orientados pelo lucro. Assim, assumiu as características capitalistas, com incorporação das modificações tecnológicas do exterior, declínio da medicina pública e crescimento da medicina previdenciária, principalmente após a reestruturação do setor, como analisado por Silva et al. (2007).

Para Nunes, durante os anos 1960, as abordagens fenomenológicas estiveram efetivamente presentes no campo do pensamento sobre a saúde, com destaque para estudos que elucidavam a relação entre o médico e demais profissionais, análises de hospitais e, entre outros, a medicina comunitária. Importa enfatizar que o hospital foi idealizado como o locus ideal para o exercício da medicina, como explicitado por Nunes (1985, p.46, destaque do autor): "A partir de 1965 é evidente o destaque de um modelo de atenção médica principalmente curativa, especializada, de elevado nível tecnológico, dependente da 'indústria da saúde' e de elevado custo". 
A focalização dada à comunidade não consegue responder as novas demandas sociais, e a compreensão dos problemas de saúde passa pelo contexto social, político e econômico. Nunes (1985) aponta que, a partir da década de 1970, é possível contar com o acréscimo da produção intelectual na área da saúde dentro do enfoque marxista. Ele situa algumas contribuições efetivas para a compreensão do processo saúde-doença: a epidemiologia social é vista como um fato social e coletivo. Da mesma forma, vê-se a reprodução social da força de trabalho evidenciada pela economia política, pela economia da saúde e pelo controle social.

A partir dos anos 1970, houve uma combinação de "repressão e assistência” (Bravo, 2006, p.95), visto que o modelo chamado "Milagre Econômico", de 1968-1973, expressão que se refere ao crescimento econômico provocado pela disponibilidade de capital externo ocorrida entre os anos 1968-1974, por determinação dos governos militares, provocou no Brasil nas décadas seguintes a aceleração da expansão industrial. Esse modelo, sustentado inclusive pela intensificação das horas trabalhadas, pela diminuição dos salários e pela submissão do trabalhador aos ritmos das máquinas, demonstrou sinais de fragilidade, em uma conjuntura de crise econômica e de deflagração do processo de organização e articulação dos movimentos sociais, sindicais e populares. O Estado, na busca de conter os conflitos sociais e superar a crise, implementou políticas sociais abrangentes como a ampliação da cobertura previdenciária, como refere Faleiros (2000).

Analisando a reestruturação das políticas sociais, Potyara Pereira (2000) relata que nos anos 1970 o crescente domínio do mercado nos processos econômicos e sociais desencadeou novas formas de expressão da questão social. Essas novas formas de expressão da "nova questão social", com o crescimento do desemprego, da pobreza e da exclusão social, têm uma amplitude global e consequências que levam ao desmonte dos direitos sociais. A autora ressalta que a concretização de direitos sociais, por meio das políticas sociais e seus mecanismos de proteção social, vão se desintegrando, e há o "[...] desmonte da cidadania social - uma das maiores conquistas democráticas e o abalo da utopia de construção sociedade livre de incertezas e desamparos sociais" (Pereira, 2000, p.56).

Laurell (1989) descreve as políticas sociais como o conjunto de medidas e instituições que tem por objetivo o bem-estar e os serviços sociais, para ampliar a cidadania, a inclusão social e política dos indivíduos. Mas, em uma 
sociedade desigual, o Estado tem um papel redistributivo, desenvolvendo políticas sociais do ponto de vista econômico com caráter compensatório e promocional, para oferecer serviços à população e controlar o modo de relações na sociedade.

Esse sistema dual de acesso às políticas sociais foi se configurando para quem pode e para quem não pode pagar. Essa é uma das principais heranças do regime militar para a política social e que aproxima mais do sistema norte-americano de proteção social que do Welfare State europeu. Outra herança é que, mesmo com alguns avanços e uma ampliação dos acessos públicos e privados, as ações de saúde pública estavam direcionadas para campanhas de erradicação de doenças, e milhões de brasileiros não tinham nenhum acesso aos serviços de saúde e permaneciam fora do complexo assistencial-industrial-tecnocrático-militar: "[...] o setor privado para os ricos, os planos de saúde para um grupo seleto de assalariados e classe média, os serviços públicos para os pagantes da previdência e para os pobres, a caridade, feita em geral por entidades municipais ou filantrópicas com apoio estatal" (Faleiros, 2000, p.48).

As abordagens fenomenológicas estiveram efetivamente presentes no campo do pensamento sobre a saúde, com destaque para estudos que elucidavam a relação entre o médico e demais profissionais, análises de hospitais e, entre outros, a medicina comunitária. O hospital foi destacado como o local ideal para o exercício da medicina, consagrando um modelo de atenção médica curativa, especializada, baseado em tecnologia de alto custo e subordinado à "indústria da saúde”, como analisa Nunes (1985, p.46).

A partir dos anos 1970, portanto, é possível contar com o acréscimo da produção intelectual na área da saúde, dentro do enfoque marxista, com algumas contribuições para a compreensão do processo saúde-doença, que na maneira de ver da epidemiologia social, é visto como um fato social e coletivo. E, também, nesta época, "[...] problematiza-se o surgimento e o desenvolvimento das políticas sociais no contexto da acumulação capitalista e da luta de classes, com a perspectiva de demonstrar seus limites e possibilidades na produção do bem-estar nas sociedades capitalistas" (Behring \& Boschetti, 2006, p.37).

O processo de modernização conservadora em que o País viveu durante a ditadura militar e o desenvolvimento baseado na industrialização e urbanização aceleradas e sem planejamento agravam a crise salarial, levam a classe 
trabalhadora à miséria, aumentam o êxodo rural, comprometem as condições de vida da população e aumentam as doenças e a mortalidade infantil. A ditadura permitiu uma deteriorização nas condições de saúde da população, tanto pelo aumento da miséria quanto pela mudança na ênfase dos investimentos em saúde e diminuição dos recursos, sucateando os serviços de saúde e abandonando programas importantes de saneamento básico e infraestrutura.

A política adotada pela ditadura levou a uma lenta e gradual distensão do regime militar, em um processo de transição democrática que, segundo Behring \& Boschetti (2006, p.138), “[...] irá condicionar a adesão brasileira às orientações conservadoras neoliberais já em curso no nível mundial”. Essa transição relacionada ao endividamento do País é um dos motivos do fim do governo militar e, do mesmo modo, aprofundamento das contradições sociais no País, com a radicalização das expressões da questão social.

A estagnação do crescimento e do próprio capitalismo tem efeitos no empobrecimento da população e na deficiência dos serviços sociais públicos, em um contexto de desemprego, aumento da demanda, retração dos direitos, concentração de renda associada à concentração do capital e incentivo da exportação baseada em produtos agrícolas e intermediários, sem considerar as necessidades internas do País. Essa estagnação é uma "reação da burguesia", como resposta à reestruturação produtiva e à mundialização do capital e do neoliberalismo, "[...] que colocam a política social em uma nova condição [...], no contexto da ditadura militar pós-1964 até o processo de redemocratização dos anos 1980, que resulta no desenho social-democrata da Constituição de 1988" (Behring \& Boschetti, 2006, p.24)

Para Conh (1997, p.231, grifo da autora), esse período do regime autoritário é marcado pelo desenvolvimento sem democracia, caracterizando-se por um modelo econômico de acumulação excludente, que tem "[...] como base investimentos no setor de bens de capital, grande presença do capital financeiro e crescentes empréstimos internacionais [...]”. A inserção da economia no mercado mundial sustenta o milagre brasileiro, de 1968 a 1975, e, apesar de haver a ampliação de benefícios e políticas sociais, a base de financiamento do sistema permanece contributiva e não se amplia.

A privatização da assistência médica concretiza-se nas décadas de 1960 e 1970, e se solidifica nestas, com apoio e atuação do Estado e crescimento dos gastos no orçamento da previdência social, que passa a "[...] ofertar assis- 
tência médica aos seus segurados fundamentalmente pela compra de serviços médicos do setor privado, que tem assim garantido um mercado cativo", lembra Cohn (1997, p.232). Como consequência, assinala a autora, um "[...] sistema privado prestador de serviços de saúde altamente complexo, com alta densidade tecnológica, e que progressivamente vai se transformando num setor de acumulação de capital”.

Porém, é também no final dos anos 1970 que o sistema de proteção social entra em colapso, provocado por fatores como a conjuntura econômica demarcada pela inflação, a dívida pública externa acentuada, os custos elevados da assistência médica previdenciária, o fim do "milagre econômico". As práticas de saúde concentravam-se na medicina dos hospitais ou nos ambulatórios previdenciários, mas diante do fim do "Milagre Econômico", o regime militar passou a demonstrar seu esgotamento, tornando-se susceptível a questionamentos.

Pereira (2000), discutindo a reestruturação das políticas sociais nos anos 1970, relata que o crescente domínio do mercado nos processos econômicos e sociais desencadeou novas formas de expressão da questão social, em uma amplitude global e efeitos comuns, desemprego estrutural, aumento da pobreza e da exclusão social, precarização e casualização de trabalho e desmonte de direitos sociais. Os mecanismos de proteção pública, desenvolvidos por meio de políticas sociais públicas que pretendiam concretizar direitos de cidadania, estão se desintegrando. Hoje, no lugar de compromisso governamental com o emprego e políticas sociais universais, "[... predominam políticas sociais residuais, casuais, seletivas ou localizadas na pobreza extrema" (Pereira, 2000, p.45).

O grande problema gerado por essa conjuntura foi o desmonte da cidadania social, observa Pereira (2000, p.45), "[...] uma das maiores conquistas democráticas e o abalo da utopia de construção de uma sociedade livre de incertezas e desamparos sociais". A perda de garantias e a exclusão social apontam "para a destruição dos vínculos que atacam um grande número de pessoas às engrenagens de uma sociedade que se pretendia integradora", e questiona ainda como "[...] um ator social subordinado e dependente poderia tornar-se um sujeito social pleno” (Pereira, 2000, p.56).

As Conferências Nacionais de Saúde, durante a ditadura militar, aconteceram com pouca participação e sob forte repressão do Estado. A 4aㅡ (CNS, 1967), com o tema "Recursos humanos para as atividades em saúde", apon- 
tou para a necessidade da formação profissional sanitarista do trabalhador da área de saúde. Já a 5a (CNS, 1975)² e a 6a (CNS, 1977) ${ }^{3}$ tiveram como foco a institucionalização e implementação do sistema nacional de saúde, e a ${ }^{\text {a }}$ CNS (1980) tem como tema central a "Extensão das ações de saúde por meio dos serviços básicos". Assim, as discussões estavam direcionadas para o deficiente sistema previdenciário e tinham pouca expressão social e política. No entanto, já existia uma movimentação social para a luta por melhores condições de vida e de saúde não apenas no Brasil, mas no mundo.

Observa-se, portanto, que até a década de 1970, as práticas de saúde concentravam-se na medicina dos hospitais ou nos ambulatórios previdenciários, mas diante do fim do "milagre econômico", o regime militar passou a demonstrar seu esgotamento, tornando-se susceptível a questionamentos. As forças sociais, até então reprimidas e repreendidas pelo regime em vigor, conseguem expressão na sociedade mediante movimentos como os deflagrados pela Anistia Internacional, a União Nacional dos Estudantes (UNE), o Movimento Sindical (especialmente o metalúrgico) e o movimento sanitário de democratização da saúde.

É certo que a concepção de saúde no Brasil, ao longo dos tempos, privilegiou uma minoria com seus serviços de assistência médica. Eles foram desenvolvidos pelas entidades filantrópicas ou ainda por meio de subsídios do sistema previdenciário aos que estavam formalmente vinculados ao mercado de trabalho e aos serviços privados comprados para esse fim, favorecendo a comercialização da saúde.

Assim, àqueles que objetivavam romper com as práticas conservadoras não cabia reproduzir as ações de saúde sem o seu questionamento. Têm de buscar os elementos favorecedores da ruptura da direção política da saúde como um produto a ser consumido, rompimento o qual ainda não foi dado e tampouco está concluído, mas como um projeto de luta de transformação da

2 A Conferência recomenda em curto prazo a realização de seminários e cursos intensivos em nível regional, focalizando as peculiaridades sanitárias regionais segundo o enfoque sistêmico, visando proporcionar difusão imediata dos conhecimentos indispensável à implementação do sistema.

3 Nesta Conferência, a discussão gira em torno da necessidade do controle das grandes endemias e a interiorização dos serviços de saúde e implementação da Política Nacional de Saúde, discutindo programas de saúde materno-infantil, vigilância epidemiológica e extensão das ações de saúde às populações rurais. 
sociedade, que se renova cotidianamente pela defesa da saúde como um direito universal.

\section{Os caminhos para a formação dos trabalhadores do SUS}

Eu me vejo como uma pessoa que está sempre em busca de conhecimento, de novos saberes, então tudo que eu posso fazer pra incrementar esse conhecimento e ter esse tipo de embasamento, eu me proponho a fazer e gosto de fazer. [...] Eu busco aprimoramento, é, por uma questão de satisfação pessoal, de segurança. Isso, de certa forma, facilita o relacionamento com as pessoas, o contato com os usuários e com os outros profissionais. (S1)

É necessário trabalhadores com maior formação pra trabalhar no SUS. Recentemente, numa Oficina Estadual de Atenção Básica em Saúde, foi muito discutido sobre fortalecer a questão da atenção básica. Eu acho que é o caminho de tudo mesmo é a atenção básica, e uma das coisas que eles falaram é fortalecer o papel do trabalhador. Por exemplo, eles querem oferecer Cursos de Capacitação para (profissionais), os que estão na rede básica, para terem um perfil pra trabalhar em saúde pública. [...] Tem um projeto do Estado que eles estão querendo agora colocar como lei. Seria mais ou menos assim... todo concurso que tiver pra Atenção Básica, para o médico atender na rede, no SUS mesmo do Estado de São Paulo, o profissional tem que ter um curso de especialização em saúde coletiva, porque ele tem que ter o perfil pra trabalhar naquilo ali. Não adianta pegar um especialista e pôr lá. Aí ele vai trabalhar insatisfeito, ele não vai ganhar o que ele acha que propôs a ganhar. Então eles querem mais para o SUS, isto está sendo conversado, eu acho que aos poucos vai evoluindo. (S2)

Desde a institucionalização do Sistema Único de Saúde (SUS), a partir da Constituição Federal de 1988, a questão do trabalho e da formação tem sido realçada como fundamental, e é a que vem sofrendo o maior processo de desregulamentação dentro da política de reforma do Estado no País. Os ideais de cidadania e dignidade da pessoa humana como direitos fundamentais foram inscritos no texto constitucional, elevando à condição de relevância pública as ações e os serviços de saúde, na medida em que ordena a saúde um direito fundamental do cidadão.

A análise do SUS, de sua criação ao processo de implementação, demonstra que, desde os primeiros movimentos pela Reforma Sanitária brasileira 
até a atual fase de implementação do Sistema, várias foram as iniciativas de regulamentar uma política de formação e desenvolvimento dos trabalhadores da saúde, o que sempre foi determinado pelos momentos institucionais do País. Assim, é no espaço das Conferências de Saúde que a sociedade articula-se para garantir os interesses e as necessidades da população na área da saúde e assegurar as diversas formas de pensar o SUS, assim como ampliar o debate sobre o sistema, para fortalecê-lo. Importa enfatizar, que "o modelo brasileiro de conferências é um dos melhores para o debate democrático de problemas da saúde, com governo e sociedade discutindo livremente as prioridades", afirma Dominguez (2006, p.8).

Entretanto, as transformações que vêm ocorrendo no mundo - no âmbito econômico, tecnológico, cultural - estão provocando mudanças nos paradigmas de educação e de formação profissional, no sentido de, cada vez mais, responder às exigências do mundo do trabalho. Os principais problemas podem ser resumidos como: a formação imprópria ou inadequada, com currículos que não se baseiam nas necessidades de saúde; pouco acesso dos trabalhadores da saúde a recursos de informações e conhecimento; condições inadequadas e inseguras no local de trabalho; políticas e práticas insuficientes para o desenvolvimento de recursos humanos, como apresenta a OMS (2007, p.24). A precarização do trabalho e o aprofundamento do modelo curativista/hospitalocêntrico têm sido apontados pela necessidade da formação dos trabalhadores há várias décadas nos espaços das conferências de saúde.

A essas mudanças somam-se aquelas orientadas pelo projeto neoliberal que passa a ter êxito nos anos 1990 (Anderson, 1995). Sua implementação e sua ideologia, traduzidas pela redução do Estado no enfrentamento da questão social, e suas múltiplas expressões confrontam-se com a do movimento de Reforma Sanitária. Destaca-se, então, o efeito contraditório de garantia dos direitos de saúde no plano legal e seu distanciamento no plano prático, provocado pela redução do papel do Estado.

Observa-se que esse progressivo afastamento do Estado de seus compromissos com a coisa pública, provocado pela adoção dos ideários neoliberais, leva-o a buscar uma política de estabilidade monetária. Sader (1995) diz que o neoliberalismo no Brasil e na Europa é filho da crise fiscal. Assim, os países foram adotando o neoliberalismo de acordo com as heranças deixadas pelos modelos hegemônicos, sendo que no Brasil esse processo fortale- 
ce-se a partir da crise da década de 1970, quando a economia vai se acomodar nos preceitos do capital financeiro.

Nos anos 1980, o governo de José Sarney dá o pontapé inicial, mas não consegue implementar com êxito a política neoliberal, em função da renovação das forças sociais e políticas que marcaram o momento da redemocratização do Estado brasileiro. Então, é na década de 1990 que são implementadas as medidas recessivas, aplicadas para alavancar a produção e os índices de crescimento econômico, e a tônica é o setor financeiro, e não o produtivo. Nota-se que é nessa época que o SUS é implementado. O resultado, como aponta Anderson (1995), da adesão por parte do Estado ao ideário neoliberal aliado às mudanças do mundo do trabalho é o desemprego maciço, diminuição dos gastos públicos com políticas sociais, adoção de medidas legais para o enfraquecimento dos sindicatos e ênfase na privatização dos órgãos do Estado. Representa um Estado forte para controlar o poder dos sindicatos e de recursos, mas parcimonioso nos gastos sociais.

Enfatiza-se que a adoção do projeto neoliberal pelo Estado brasileiro acaba provocando um distanciamento entre as medidas de proteção social garantidas no texto legal e as que vêm sendo praticadas. Nas palavras de Iamamoto (2006, p.188), “[...] subordina os direitos sociais à lógica orçamentária, a política social à política econômica, em especial às dotações orçamentárias e, no Brasil, subverte o preceito constitucional". Ao discutir o que chama de subversão dos direitos sociais, Iamamoto (2006, p.188) aponta para a inversão das regras, ou seja, "[...] ao invés do direito constitucional impor e orientar a distribuição das verbas orçamentárias, o dever legal passa a ser submetido à disponibilidade de recursos". A autora mostra ainda, no mesmo texto, que as prioridades dos gastos públicos na viabilização dos direitos sociais são reféns " [...] do balanço entre crédito e déficit no 'cofre governamental', estabelecida pelo bloco do poder".

O núcleo temático mais importante das políticas sociais na vertente neoliberal é o afastamento do Estado de suas responsabilidades sociais, implicando em retrocessos da cidadania tanto no plano legal quanto no prático, uma vez que acaba ocorrendo sua restrição, e não sua ampliação. A discussão de Pereira (2006, p.109) acerca dos conceitos de cidadania e justiça social analisa o efeito do impacto neoliberal em suas condições de efetivação e argumenta que "[...] sob o neoliberalismo, mais do que nunca ficou claro que os direitos de cidadania são de fato direitos dos ricos em um mundo repleto de pobres". 
O papel do Estado é demarcado pelas políticas de ajustes e pela necessidade de saldar a dívida externa, contraída em organismos internacionais como o Banco Mundial e o Fundo Monetário Internacional (FMI). O fato é que esse afastamento é contraditório, já que o Estado retrai-se para os gastos com as políticas sociais, mas se amplia para a proteção dos grandes oligopólios. Pode-se concluir esse raciocínio com a observação de Oliveira (1995) sobre o que chama de neoliberalismo à brasileira, destacando que, enquanto a economia se recupera, o social piora. Em função dessa proposta política (neoliberal), os princípios que outrora alimentaram o tão aclamado Estado de Bem-Estar (Welfare State) perdem teor, e os gastos com serviços sociais universais de proteção social básica e pleno emprego são apontados como os responsáveis pela crise econômica.

Assim, as modificações na dinâmica do capitalismo internacional aprofundaram-se, demonstrando alguns elementos de indicação das transformações estruturais que configuram a globalização econômica, como a internacionalização dos mercados, a formação de blocos regionais, os menores custos de produção e de mão de obra barata, o fraco poder de organização sindical, a desmobilização de movimentos sindicais e sociais e consequente ameaça aos direitos sociais e trabalhistas.

Esse processo de internacionalização do capitalismo gerou um novo padrão de relacionamento econômico entre os países e a criação de alternativas traduzidas em políticas de perfil neoliberal escolhidas como saída para a crise econômica. As características marcantes dessas políticas é que defendem mudanças na relação das responsabilidades e atribuições do Estado por meio de privatizações, objetivando diminuir os gastos públicos, a não intervenção estatal na economia na perspectiva do Estado mínimo, com a ênfase no mercado e o desmonte das políticas sociais.

O fortalecimento desse processo amplia, nesse período, as desigualdades econômicas, e as consequências sociais são visíveis, como o desemprego estrutural, a desregulamentação do trabalho, o crescimento dos empregos precários, a exclusão de muitos trabalhadores do mercado formal e o empobrecimento da população. Desta forma, a globalização econômica corresponde à globalização da questão social, com o aumento da exclusão social e o agravamento das diferenças sociais entre os países ricos e os pobres e dentro de um mesmo país (Dowbor, 1995). 
Diante do aumento da desigualdade e miséria social, a sociedade civil, a família, a comunidade e os grupos sociais e religiosos passam a ser responsáveis pelo atendimento das necessidades sociais, regidas de modo focalizado e sem a regulação direta do Estado: é a refilantropização. Bravo \& Matos (2002), ao analisarem o Plano Diretor da Reforma do Estado, ${ }^{4}$ iniciado em 1995, apontam que a Reforma Estatal fez-se necessária como base do projeto neoliberal, com o objetivo de fortalecer o próprio Estado e recuperar as finanças e a administração gerencial, delimitando suas funções e reduzindo seu grau de interferência. A polêmica, dizem os autores, reside na ineficiência da Reforma do Estado, que, travestida de tecnicismo, ignora a crise orgânica do capitalismo, centrando-a apenas como a de um modelo governamental, que, caso mude, resolveria a situação instalada.

Desta análise, destaca-se a criação de espaço para as Organizações Públicas Não Governamentais (Opnes) ou Organizações Sociais (OS), que passam a assumir as responsabilidades inerentes às políticas sociais. Desse modo, o Estado privatiza aqueles serviços que não cumprem papel estratégico e “[...] propõe que os serviços de saúde, educação, pesquisa e meio ambiente sejam transformados em Opnes, ou seja, sociedade de direito privado, sem fins lucrativos, que administrariam com subvenções dos cofres públicos" (Bravo \& Matos, 2002, p.207).

Alguns pontos problemáticos, como o controle social (que nas Opnes tem o caráter da composição paritária prejudicada) em seu poder de decisão, fazem com que a responsabilidade desloque-se para a sociedade civil e para o cidadão/usuário/consumidor. Esteé um ponto que se deve frisar, porque, se já não fosse bastante a expansão do neoliberalismo sem resistências mais significativas, ainda há sua interferência destrutiva nas estruturas formais de participação e de interlocução entre sociedade e Estado. Nesse aspecto, Netto (1995, p.33) comenta que o aumento da desigualdade social e a degradação das condições de vida "[...] engendrou um desalento, uma desqualificação, uma desesperança tais, em face da ação política e dos espaços públicos, que acabaram por ser funcionais às propostas neoliberais".

4 Bravo (2006, p.100) destaca que "O Plano Diretor considera que há o esgotamento da estratégia estatizante e a necessidade de superação de um estilo de superação pública burocrática, a favor de um modelo gerencial que tem como principais características a descentralização, a eficiência, o controle dos resultados, a redução dos custos e a produtividade". 
Bravo (2006) aponta que, na Reforma do Estado, a responsabilidade direta pelo desenvolvimento econômico e social deixa de ser papel específico do governo para situar-se no âmbito público não estatal vinculado às leis de mercado. Como consequência, os direitos sociais ampliados pela Constituição de 1988 tornam-se distantes do usufruto do conjunto dos trabalhadores. Assim sendo, a partir da década de 1990, os defensores neoliberais responsabilizam as diretrizes e princípios de universalidade pelo volume da dívida pública, e defendem a necessidade de substituir as políticas sociais por programas focais e de responsabilidade da sociedade civil.

A lógica da privatização das políticas públicas extrapola as áreas da saúde e da educação e chega ao desenvolvimento social com o Programa de Economia Solidária. Conclama a participação da sociedade e do mercado na gestão e financiamento das políticas sociais e ainda estabelece que, na ausência do Estado de direito, o cidadão pode contar com a solidariedade social e serviços comunitários.

As significativas transformações, tomando por base Dowbor (1998, p.3), e a "[...] opção por um modelo de desenvolvimento pautado exclusivamente pela ótica econômica, sem preocupação com o indivíduo ou com as comunidades e sociedades", demonstram como está cada vez mais difícil identificar o bem-estar humano com o bem-estar da economia. As expressões dessa situação estão assinaladas, refere o autor (Dowbor, 1998, p.4), de um lado pelos avanços tecnológicos e as formas de crescimento econômico e, “[...] de outro, pelas necessidades como seres humanos comprometidos na dimensão da sua cidadania”. Como ensinaram Marx \& Engels (2006, p.36), o modo de vida dos indivíduos é determinado pelo modo de produção de sua vida material.

A produção das ideias, das representações, da consciência está, de início, diretamente entrelaçada com a atividade material e com o intercâmbio material entre os homens, como a linguagem da vida real. O representar, o pensar, o intercâmbio espiritual dos homens aparece aqui como emanação direta de seu comportamento material [...], os homens são produtores de suas ideias, etc... mas os homens reais, ativos, tal como se acham condicionados por um determinado desenvolvimento de suas forças produtivas e pelo intercâmbio que a ele corresponde.

As constantes críticas e o questionamento persistente do projeto de Reforma Sanitária têm resultado na articulação do mercado, com vistas a esta- 
belecer um modelo de política de saúde conhecido pela característica privatista. A partir do receituário neoliberal o papel do Estado restringe-se, e os recursos são racionalizados, vulnerabilizando a efetiva universalização e a qualidade do acesso à saúde, não consolidando seu bem mais precioso, a construção de uma nova consciência sanitária e política, na "[...] perspectiva transformadora da área pública” (Campos, G. W. S., 1997, p.133).

Apesar dos avanços com os aspectos preventivos, a cobertura de assistência a 140 milhões de habitantes, para Coelho (2007, p.310), tem um reflexo "[...] na formação do imaginário popular do que é ou não um bom sistema de saúde. É exatamente esse imaginário que mobiliza os desejos dos cidadãos" e convive como um paradoxo entre a defesa dos princípios do SUS e a alternativa por um plano de saúde privado para a própria assistência médica. Um dos fatores de satisfação com os convênios de saúde particulares pela parcela dos usuários que a eles têm acesso (Coelho, 2007, p.311) é o "leque de opções" sobre o qual têm certa alternativa de escolher o próprio médico e/ou os serviços. Na realidade, deve-se acrescentar a essa cifra mais uma grande parte dos 40 milhões assistidos pela medicina supletiva, os quais não têm planos de cobertura integral e migram para o SUS para aqueles procedimentos não cobertos pelo seu convênio, conforme análise de Coelho (2007).

O desafio mais persistente para a implementação do SUS passa a ser a integralidade, como forma de evitar que o sistema de saúde pública constitua-se de programas focais voltados aos menos favorecidos. Cabe reavaliar que a proposta oficial avançou com a estratégia Saúde da Família, contudo, a própria organização desse programa de saúde, para funcionar, necessitava da contratação de profissionais cujas categorias nem eram regulamentas ainda como as de "[...] auxiliar e técnico de saneamento, agente de vigilância sanitária, agentes de saúde” (Bravo, 2006, p.105). Essa situação foi agravada pelo processo de admissão desses trabalhadores, que seguiu o viés da precarização e da terceirização, não viabilizando a qualidade e humanização dos serviços de saúde a serem prestados.

O setor de saúde, apesar do compromisso com os ideais integralizadores da Reforma Sanitária, ao implementar as políticas de modo fragmentado, perpetua a falta de integração entre os conteúdos propostos enquanto nega os saberes, desejos e experiências acumulados dos usuários. A política de saúde vincula-se aos processos econômicos, políticos, culturais e ideológi- 
cos, e a sua constituição enquanto prática social relaciona-se ao modo de desenvolvimento social do País.

Há uma estreita relação entre as opções de desenvolvimento, as liberdades e as condições de vida desfrutadas pela população e as práticas educativas instituídas (SEN, 2000). Neste aspecto, considera-se condicionante a dimensão político pedagógica nos serviços de saúde tanto para os usuários que buscam os serviços quanto para os trabalhadores da saúde. Essa ação demanda que os serviços de saúde e seus trabalhadores estejam preparados para atender aos usuários em todas as suas necessidades, e ao mesmo tempo, que esses trabalhadores possam também, por meio do trabalho, ter suas necessidades atendidas, exercitando os direitos garantidos na legislação. A fim de orientar a implementação definitiva dos preceitos do SUS, tanto a formação profissional como o processo de trabalho foram transformados em política nacional pelo processo de educação permanente.

A 8a Conferência Nacional de Saúde (CNS, 1986), além de ser um marco histórico para a confirmação do SUS, apresentou um conjunto de formulações para a área de trabalhadores da saúde, em que foram discutidas e sistematizadas as principais propostas para a elaboração de uma política, essenciais para a Reforma Sanitária brasileira. A 8 a CNS apresentou "[...] um retrato das transformações e crises acumuladas ao longo das diversificadas e desarticuladas políticas de saúde e educação. Mais ainda, configurava a crise econômica e social que se apoiava no setor Saúde como importante gerador de empregos" (Brasil, 1993, p.8).

A construção de uma política assinalada pelo processo de descentralização da assistência e, consequentemente, dos recursos humanos que integram os serviços, foi estabelecida na $8^{\mathrm{a}} \mathrm{CNS}$, a qual formatou as diretrizes e propostas que foram aprofundadas na $1 \underline{\underline{a}}$ Conferência Nacional de Recursos Humanos para a Saúde (CNRHS), que acontece também em 1986 com o tema a "Política de Recursos Humanos Rumo à Reforma Sanitária". Essa Conferência contou com cerca de quinhentos participantes, entre profissionais da área de saúde, educação, trabalho e administração e usuários do setor, e deu continuidade na construção de um pensamento na perspectiva do trabalhador da saúde e questões referentes ao processo de trabalho.

A questão referente às condições de trabalho, com ênfase no setor público, volta-se para a construção de uma nova ética social que estabeleça um compromisso mais democrático das instituições para com a sociedade, cons- 
tituindo-se uma luta no sentido de uma sociedade menos individualista e mais justa.

A 1를 CNRHS cumpriu seu papel e detalhou uma agenda para o movimento da Reforma Sanitária no tocante à Política de Desenvolvimento dos Trabalhadores para o Setor Saúde. Os debates foram marcados por uma “[...] busca de recuperação da liberdade e cidadania: a questão da saúde torna-se uma reivindicação popular" (Brasil, 1993, p.9), e o tema é desenvolvido em cinco partes: "[...] valorização profissional, preparação de recursos humanos, órgãos de desenvolvimento de recursos humanos para a saúde, organização dos trabalhadores de saúde e relação dos trabalhadores de saúde com usuários dos serviços".

Essa Conferência introduz uma nova discussão em torno da questão dos trabalhadores da saúde, entretanto, estão presentes problemas de falta de integração ensino/serviço, distanciamento das instituições formadoras da realidade social e outros conflitos de interesse entre o sistema de saúde e o sistema formador (Brasil, 1993). Seu Relatório “[...] passou a servir de referência de base às discussões e produções técnico-científicas que se seguiram" (Brasil, 2005e, p.2).

A questão da municipalização foi o tema central da 9aㅡ Conferência Nacional (CNS, 1992), voltada para a efetiva implementação do SUS. Enfatiza como indispensável uma Política Nacional de Gestão do Trabalho, visualizando a impossibilidade da implementação do SUS sem o tratamento de forma ordenada de sua força de trabalho. Realizada em um momento de crise econômica, pouco se acrescentou ao debate travado na $8^{a}$ CNS em relação ao desenvolvimento dos trabalhadores da saúde. Porém, a 9a CNS reafirma a necessidade de uma política de recursos humanos para o SUS e aponta para a necessidade de realização da 2a ${ }^{\underline{a}}$ CNRHS (1993), para aprofundar a análise das questões relacionadas à necessidade de universidade pública gratuita e autônoma e à inclusão no currículo de formação de profissionais de saúde para estágio obrigatório na rede básica de serviços, e assim, produziu um diagnóstico dos "[...] problemas e contradições que enfrentavam os profissionais da área, desde a formação às precárias condições de trabalho. Estes se expressariam na falta de motivação para o trabalho nas instituições públicas de saúde, traduzida como um descompromisso ético e social" (Brasil, 1993, p.9).

Assim, a 2a CNRHS (1993) produziu um dos mais densos e completos documentos sobre o tema, fundamentada na constatação da ausência de uma 
política para os trabalhadores da saúde e as consequências prejudiciais para a implementação do SUS, e indicou a necessidade de se regular imediatamente o artigo 200 da Constituição Federal (Brasil, 1988). A proposta da Reforma Sanitária passa a orientar a política dos trabalhadores da saúde (de $\mathrm{RH})$, visando atender às demandas do SUS. No entanto, com o avanço do processo de implementação do SUS, segundo Machado (2006, p.24), "a realidade que se apresenta para a área de $\mathrm{RH}$ remete a mais dois momentos distintos". Durante a década de 1990, caracterizada pela adoção dos preceitos neoliberais em detrimento aos da Reforma Sanitária, "transformou a questão de RH, ao longo da década de 1990, em um enorme problema para a Reforma Sanitária, invertendo toda a lógica preconizada no processo da Reforma", de serem os trabalhadores "peças-chave para a consolidação do SUS" (Machado, 2006, p.24).

A busca pelo aprimoramento do SUS e de seus trabalhadores fortaleceuse na 10른 CNS (1996), que priorizou debates a partir do tema "OSUS - construindo um modelo de atenção à saúde para a qualidade de vida”, e buscou estratégias para o financiamento do Sistema. Em seu Relatório Final, ficou estabelecido um prazo (90 dias a partir de sua publicação) para o Ministério da Saúde elaborar, com ampla participação e discussão e aprovação pelo Conselho Nacional de Saúde, “[...] uma Norma Operacional Básica de Recursos Humanos com princípios que regulem a ação e a relação das esferas de governo com relação aos trabalhadores no âmbito do SUS, e que inclua uma "agenda de prioridade" para a implantação desta política" (Brasil, 2005e, p.59).

Entretanto, foi apenas a 11aㅡ CNS (2000) que aprovou os princípios e diretrizes para a Norma Operacional Básica de Recursos Humanos (NOB $\mathrm{RH}$ ), após um intenso debate promovido durante toda a década de 1990, envolvendo os diferentes segmentos do controle social e dos gestores para a conformação dessa Norma, que hoje baliza os indicativos da política de recursos humanos para o SUS. A elaboração da Norma Operacional Básica de Recursos Humanos para o SUS (NOB/RH-SUS) e sua regulamentação em $2004^{5}$ define os princípios e diretrizes e teve como objetivo principal a cen-

5 Resolução no 330 do Conselho Nacional de Saúde, de 4 de novembro de 2003. "Princípios e Diretrizes para a Norma Operacional Básica de Recursos Humanos para o SUS (NOB/RHSUS)". Esses princípios e diretrizes têm por finalidade estabelecer parâmetros gerais para a 
tralidade do trabalho, do trabalhador, da valorização profissional e da regulação das relações de trabalho em saúde (Brasil, 2005c). A elaboração da $\mathrm{NOB} / \mathrm{RH}$ - SUS foi um processo democrático e descentralizado, e contou com importante participação de trabalhadores, gestores e controle social em suas negociações nos espaços das Conferências e do Conselho Nacional de Saúde (Brasil, 2005d).

As dificuldades apresentadas mostram os poucos resultados alcançados com a NOB/RH - SUS, uma vez que a política que prevaleceu nesse período foi a política neoliberal para Recursos Humanos, priorizando a privatização por meio da terceirização de serviços, da abertura de novos cursos na área da saúde, entre outras questões afins. O SUS necessita, portanto, da efetividade de políticas públicas específicas e intersetoriais para assegurar a cobertura universal e para promoção, proteção e recuperação da saúde, bem como a valorização do trabalho como instrumento essencial da atenção à saúde e criação de vínculo dos trabalhadores com a população e os serviços. Resumidamente, Machado (2006, p.25) esclarece que a década de 1990 é

caracterizada, pelo abandono da proposta de planos de carreira profissional, pela precarização do trabalho no SUS, pela desmobilização do movimento sindical identificado na perda da importância da negociação do trabalho no SUS, pela pulverização das ações educativas e formativas no âmbito do SUS e pela proliferação de escolas de saúde. Sem dúvida, a década de 1990 pode ser denominada década perdida para os recursos humanos em saúde. Uma década marcada pela insistência de consolidar o SUS sem se preocupar com aqueles responsáveis pela produção dos serviços de saúde nas três esferas que compõem o SUS. O saldo político é uma enorme dívida social com os trabalhadores.

Nesse contexto, a "mão de obra em saúde" proporcionada pelo aparelho formador, voltada para o mercado de trabalho, toma uma dimensão política e social por não ser adequada às necessidades de saúde da população brasileira nem às necessidades dos serviços. Essa situação impõe o enfrentamento de problemas e fortalece cada vez mais a pressão para a formulação de uma política de pessoal para o setor saúde e, a partir dela, de medidas que contri-

Gestão do Trabalho no SUS, como Política Nacional de Gestão do Trabalho e da Educação em Saúde, no âmbito do SUS (Brasil, 2004d). 
buam na formação de profissionais que atendam às necessidades concretas dos serviços públicos de saúde.

O trabalho na saúde compôs um dos assuntos da $12^{\text {a }}$ CNS (2003). A "Saúde é um Direito de Todos e Dever do Estado - a saúde que temos e o SUS que queremos", tema central que orientou o Plano Nacional de Saúde e reforçou a imediata adoção da Política Nacional de Gestão do Trabalho e da Educação na Saúde como instrumento efetivo para a consolidação do SUS, concluindo que essa medida trará a valorização do trabalhador e contribuirá de maneira efetiva para a criação de vínculo entre o trabalhador e os serviços de saúde pública (Brasil, 2005c).

O intenso exercício de democracia, historicamente vivenciado na saúde pelos trabalhadores em todo o País, fortaleceu-se ainda mais na $3^{\text {a }}$ Conferência Nacional de Gestão do Trabalho e da Educação na Saúde (CNGTES) em 2003, que com o tema "Trabalhadores de saúde e a saúde de todos: práticas de trabalho, gestão, formação e participação", estabeleceu diretrizes nacionais para a Política de Gestão do Trabalho e da Educação na Saúde, visando ampliar a participação dos trabalhadores e a corresponsabilidade no SUS. Essa Conferência vai procurar superar os problemas e buscar soluções concretas para resgatar e efetivar as propostas que a Reforma Sanitária tem para os trabalhadores do SUS (Brasil, 2005c).

O ano de 2003, na análise de Ceccin (2005a, p.92), é assinalado "[...] pelo retorno aos princípios de que saúde é um bem público e os trabalhadores que atuam são um bem público”. Para o autor, o governo federal (governo Lula) "[...] inaugura um novo momento para a área de RH" (2005a, p.92), para dar execução na NOB-RH/SUS, foi criada, no âmbito do Ministério da Saúde, a Secretaria de Gestão do Trabalho e da Educação na Saúde (SGTES), com objetivo de "implementar uma política de valorização do trabalho no SUS e dos trabalhadores de saúde em conformidade com os seus princípios e diretrizes" (Brasil, 2005d, p.5), passa a tratar especificamente da gestão dos recursos humanos na dimensão do trabalho e da educação na saúde.

A criação da Política de Formação e Desenvolvimento para o SUS: caminhos para a educação permanente em saúde e a estratégia de Polos ou rodas de Educação Permanente em Saúde ${ }^{6}$, em 2003, assinala a valorização do de-

6 Resolução nº 335, de 27 de novembro de 2003 (Brasil, 2003a). 
bate acumulado, a iniciativa e compromisso governamental, juntamente com a pressão do controle social da saúde, apontando novos caminhos que "rompem com a ideia de que o trabalhador é apenas mais um recurso de infraestrutura, reconhecendo-o como protagonista do processo de consolidação do Sistema” (Brasil, 2005d, p.5). Essa ação traz “[...] esperança e confiança tanto para aqueles que produzem os serviços de saúde para a população como para os responsáveis pela gestão dos sistemas de saúde", afirma Machado (2006, p.87).

De acordo com o Relatório Final ${ }^{7}$ da $13^{\text {a }}$ Conferência Nacional de Saúde (CNS), realizada em 2007, essa Conferência "[...] se consagrou como o maior encontro do setor saúde do planeta", e foi uma oportunidade de fortalecimento democrático dos direitos sociais e "[...] da caminhada certa e produtiva do Sistema Único de Saúde rumo ao século XXI justo e igualitário” (Brasil, 2008, p.9). A intenção de fortalecer os princípios da Reforma Sanitária, a saúde como direito de Seguridade Social e elemento fundamental do desenvolvimento social do País, a discussão esteve voltada para o tema "Saúde e Qualidade de Vida: políticas de Estado e desenvolvimento”.

Também a 13a CNS destaca a importância de efetivar a saúde como direito de todos e dever do Estado (Art. 196), assegurando a efetivação de diretrizes e princípios do SUS nas três esferas de governo, independente da administração vigente, "[...] reconhecendo a diversidade populacional e suas especificidades de gênero, etnia, raça, crença, cultura, geração, orientação sexual, deficiências e procedências regionais, garantindo a equidade na atenção integral para a formulação de políticas e ações", apontando qualidade de saúde e de vida (Brasil, 2008, p.71). Nesse processo, deve-se pensar na formação dos trabalhadores da saúde como os protagonistas da Reforma Sanitária, que possuem o conhecimento, a técnica, o saber e o trabalho a serem colocados em benefício da população brasileira.

O cumprimento da Política de Recursos Humanos para a Saúde, NOB/ RH - SUS, é amplamente discutido na 13a CNS e indica que possibilite aos trabalhadores da saúde participar da dinâmica do trabalho, valorizando e

7 “Dos 5.564 municípios brasileiros, 4.430 realizaram suas Conferências Municipais, 77\% de todos os municípios do País. Quase cinco mil pessoas, entre gestores, trabalhadores, usuários, parlamentares e professores, na qualidade de delegados e observadores, compartilharam desse encontro, o maior e mais importante para a saúde no Brasil” (Brasil, 2008, p.7). 
permitindo seu crescimento, a melhoria do serviço, além de outras questões relacionadas. As propostas aprovadas da formação e desenvolvimento dos trabalhadores da saúde, como já apontado, exigem responsabilidades do Ministério da Saúde, das secretarias estaduais e municipais de saúde para implementação da Portaria MS no 1.996/07, que disponibiliza recursos para a educação permanente em saúde de forma descentralizada para trabalhadores e gestores. Entre as deliberações da $13^{\text {a }}$ CNS, destacam-se algumas que competem responsabilidades nos três níveis de governo:

Proporcionar, por meio de políticas públicas, o acesso à qualificação e ao conhecimento, criando cursos profissionalizantes e ou de qualificação profissional para todos os servidores e profissionais da rede SUS, estabelecendo uma política de capacitação de recursos humanos, fortalecendo as Escolas Técnicas da Saúde e transformando-as em verdadeiros centros de referência regional/estadual, favorecendo a unificação de informações estratégicas para a atuação profissional. [...] fomentar a formação específica de gestores de saúde em instituições públicas, visando à eficiência e à eficácia na gestão pública, em compatibilidade com as necessidades do SUS, favorecendo que todos os gestores de unidades sejam profissionais habilitados e/ou qualificados na área da Saúde para a função.

[...] constituir e implementar uma Política de Gestão do Trabalho e da Educação Permanente em Saúde que possibilite a identificação de necessidades e potencialidades loco-regionais [...], capaz de produzir mudanças na gestão, na atenção, na formação, na participação em saúde, e modificações nos processos de trabalho no SUS, promovendo a integração dos processos de capacitação e desenvolvimento de recursos humanos, formando os Núcleos de Educação Permanente em Saúde, descentralizados, numa perspectiva multiprofissional, interdisciplinar e intersetorial para todos os trabalhadores do SUS (Brasil, 2008, p.90).

As competências do Ministério da Saúde em apoiar as secretarias estaduais e municipais de saúde na capacitação e qualificação dos trabalhadores da saúde, a partir das necessidades do SUS, conforme Relatório da 13ª CNS (Brasil, 2008, p.94), incluem inclusive a formação

de pós-graduação, especialização, mestrado, doutorado, que busquem refletir sobre as problemáticas do mundo do trabalho visando à valorização do profissional e à ressignificação de suas práticas, induzindo a integralidade do cuidado e a humanização do próprio sistema com a efetivação dos princípios e diretrizes do SUS. Utilizar, nas atividades de educação permanente, metodologias que 
busquem propiciar a formação de sujeitos por meio do diálogo, da troca de conhecimentos, da ludicidade, da afetividade e da compreensão e significação ativa sobre o cotidiano do trabalho para o atendimento e esclarecimento à população, com ênfase na humanização, promoção da saúde, integralidade e, resolutividade nas temáticas de gênero, violência, dependência química, DST/ HIV/Aids, hipertensão/diabete, saúde mental, grupos terapêuticos, autocuidado, cidadania e outras.

No que se refere ao distanciamento da formação e prática, essa Conferência apresenta como solução o fortalecimento da aproximação dos Ministérios da Saúde e da Educação, e dos espaços de ensino-aprendizagem dentro do SUS para normatizar os campos de integração/interação ensino-serviço e incentivar a implementação e o funcionamento de ações de educação permanente nos municípios para campo de trabalho e de estágio dos estudantes. E o fortalecimento da participação intersetorial e coletiva, contemplando a representatividade e os interesses dos diversos segmentos no SUS, e o compromisso dos gestores no processo de educação permanente dos trabalhadores da saúde (Brasil, 2008).

Assim, torna-se prioridade a articulação intersetorial - universidades, cursos técnicos da saúde, serviços, gestão e controle social - na formulação de políticas e de projetos de educação permanente em saúde que aproximem as diferentes realidades sociais dos municípios e das regiões ao processo pedagógico de formação em saúde. A introdução "de conteúdos referentes às políticas de saúde, à humanização, à atenção básica, enfatizando a visão da integralidade do cuidado e formando, assim, profissionais com perfil voltado à promoção e à atenção à saúde, e comprometidos com o SUS" (Brasil, 2008, p.95).

Deste modo, tanto o Ministério da Saúde como as secretarias estaduais e municipais de saúde são responsáveis pela formação e qualificação permanente dos trabalhadores da saúde, apontando o desenvolvimento de ações de educação em saúde com a população a partir da realidade local e regional. Enfim, ao retomar essa história, percebe-se que em quase sete décadas de Conferências Nacionais de Saúde ${ }^{8}$, as propostas referentes à gestão do tra-

8 As Conferências de Saúde iniciaram em 1941, cumprindo o disposto no parágrafo único do artigo 90 da Lei n⿳⺈ 378, de 13 de janeiro de 1937, ora regulamentada na Lei no 8.142, de 28 de dezembro de 1990 . 
balho e da educação em saúde foram recorrentes para que os problemas que afetam o processo de trabalho no SUS encontrassem soluções, ainda que sem todos os avanços desejados. A falta de integração das políticas públicas, apesar do excessivo debate nas Conferências, mostra, por um lado, a incapacidade da sociedade atual de integrar pessoas, interesses coletivos e respeitar culturas e diversidades com iniciativas pontuais, fragmentadas e sobrepostas. Por outro, demonstra que o intenso exercício de democracia, historicamente vivenciado pelos atores sociais na saúde, resulta em conquistas e realizações e evidencia que o projeto da Reforma Sanitária está em movimento e resiste ao projeto neoliberal.

A construção da Política de Formação e Desenvolvimento para o SUS: caminhos para a Educação Permanente em Saúde e a estratégia de Polos ou rodas de Educação Permanente em Saúde é, deste modo, fruto de uma luta coletiva e um instrumento para efetivar a Reforma Sanitária brasileira e consolidar o Sistema Único de Saúde.

Sua materialização exige o exercício permanente de sua defesa, cuja implementação depende das três esferas de gestão do SUS e da participação dos órgãos de controle social da saúde, das instâncias intersetoriais e interinstitucionais e da presença ativa dos atores sociais da saúde. 


\section{4 \\ Perspectivas da Educação Permanente em SAÚdE}

\section{A implementação da Política de Educação Permanente em Saúde}

A implantação da política de educação permanente é um grande avanço, é um caminho promissor a curto, médio e a longo prazo. Ela contribui significativamente para a nossa formação pessoal, profissional e também para desempenharmos bem nosso trabalho dentro do serviço de saúde. E o que ocorre é que em alguns municípios, a educação permanente está truncada, está direcionada para alguns, o objetivo é levá-la para todos. [...] Hoje, sentimos que fomos alijados desse processo, $[\ldots]$ porque não houve continuidade, nós tentamos fazer reuniões periódicas, o pessoal que fez o curso acabou desmotivado por falta de apoio da gestão. (S1)

Eu acho que, nossa... é um ganho muito grande. [...] Porque antes, eu sempre brinco que treinamento, capacitação, era igual encontro de casais: você ficava só final de semana lá. Se saía beijando, aí ficava lindo! Depois continuava tudo errado de novo. Começava a brigar. Por quê? Porque é uma coisa só, palestra, curso, capacitação, treinamento, passou a ser uma coisa de alguém que ia lá ouvia uma coisa. Eu acho que é importante você ouvir, mas que de repente não afetava aquela pessoa para qual eu estava falando, ou ela não dava tanta importância. Ou era assim, alguma coisa que a gente julgava ou que julgavam pra gente, e que a gente tinha que fazer, mas que não via uma relação. Por quê? Por que eu tô fazendo isso? Entendeu? Isso tem significado pra mim? O que esse cara está falando? Por que eu tenho que seguir o que ele tá falando pra mim? Ele não sabe, ele não tá lá no meu serviço pra ver a chateação... Então, eu acho que a Política, ela vem quebrar isso. Eu acredito que a Política de Educação Permanente [...] é um processo que você constrói junto com a pessoa, com o trabalha- 
dor da saúde, isso tem sentido pra você? Porque você tá fazendo isso? Dá pra ser diferente? Então, vamos buscar aquilo que você acha que vai fazer você se sentir bem no trabalho e você ter seu trabalho melhor. (S2)

Olha, pra mim contribuiu, sim. Eu aprendi a como lidar mais com o público, entendeu? Atender mais as necessidades deles (dos usuários). Tentar atender melhor, passar pro pessoal daqui de uma maneira mais humana de atender o usuário. E pra mim é uma grande satisfação. Porque a gente teve o conhecimento maior. (S3)

É, que pena que parou, né? Não pode parar. O próprio nome fala: é permanente. Então, tem que continuar. E por que interrompeu? Não é, foi interrompido. É a mesma coisa que eu falei da rede. Se você corta um fio, então isso aí não deveria parar, deveria continuar. A gente sempre tem que tá reciclando, reciclando talvez seria lixo, material. Mas por que não qualificar o funcionário? Ele tem que ter uma educação sempre, tem que continuar isso aí, não pode parar. É uma pena. [...] Não dão nem satisfação do que tem acontecido, nada. Como tá? Não tenho notícias. Infelizmente. (S4)

Pode-se observar nas falas dos sujeitos o reconhecimento da implementação da Política de Educação Permanente em Saúde para a formação e o desenvolvimento dos trabalhadores da saúde no contexto do Sistema Único de Saúde (SUS). Do mesmo modo, é compreendida como uma necessidade para melhorar as relações entre os sujeitos envolvidos na saúde e ampliar a participação dos atores sociais da saúde. Portanto, as falas indicam que a Política de Educação Permanente em Saúde (EPS) tem elementos para aprimorar o processo de trabalho, uma vez que a formação sugerida parte das necessidades sentidas pelos sujeitos.

O trânsito das ações de educação na área da saúde, como analisado anteriormente, é resultado do processo histórico-político que atravessou do âmbito particular e privado para a responsabilidade social e pública, determinada pela correlação de forças sociais, econômicas, culturais e políticas. É essa correlação de forças que constrói a política pública, seu modo de organização, financiamento, gestão e operacionalização das diretrizes assumidas. Cabe, então, desvendar alguns dos avanços e das contradições que permeiam a temática aqui tratada.

A compreensão predominante do processo de educação, no contexto brasileiro, expressa muitas vezes as ideias e práticas de mercado que não repre- 
sentam uma agenda estratégica capaz de refletir as demandas sociais e representações da complexa estrutura da sociedade. Tornam-se incapazes de ir além dos problemas aparentes e particulares e transcendem para o coletivo, no reconhecimento da desigual concentração de renda, do processo de trabalho, da falta de planejamento urbano, de oportunidades educacionais, ao acesso à saúde, à água potável e à moradia de qualidade. São esses os eixos estruturantes e norteadores do processo de educação em saúde que, dentre outros, conformam o quadro que constitui a realidade social.

A ênfase da educação na sociedade atual é a do mercado, o que torna, então, necessário esclarecer que educação permanente em saúde, no entendimento do SUS, refere-se ao processo de ensino-aprendizagem, é "[...] a aprendizagem no trabalho, onde o aprender e o ensinar são incorporados ao cotidiano das organizações e do trabalho" (Brasil, 2005b, p.12), considerada um suporte na implementação do SUS, de tal modo que efetive o conceito ampliado de saúde. Difere das propostas de transferência de conhecimentos, que aponta as necessidades cada vez mais exigentes de um perfil de trabalhador polivalente, qualificado ou ainda bem treinado.

Assim, a abrangência do processo de educação transportado para as questões de saúde pode desencadear ações educativas sustentadas nos paradigmas referenciais da promoção humana. Então, a educação permanente em saúde pode ser uma estratégia para transcender o pensamento tradicional (agente-corpo-hospedeiro), ainda vigente na prática dos serviços de saúde, para promover a reflexão das condições materiais de vida e seus laços fecundos na saúde.

O olhar dirigido à construção das políticas de intervenção estatal no campo da saúde procura não se restringir apenas à simples periodização da prática médica e dos modelos de organização dos serviços criados, mas identificálos em decorrência do processo produtivo, como alerta Teixeira (1989). Assim é que se busca sublinhar as relações contraditórias representadas na luta de classes e na conformação da política de saúde enquanto intervenção estatal e, portanto, papel do Estado, conforme analisam Lourenço \& Bertani (2006).

A Reforma Sanitária brasileira, embora tenha incorporado em seu discurso e na legalizada estrutura do setor saúde a necessidade da "[...] organização de um sistema de formação de recursos humanos em todos os níveis de ensino, inclusive de pós-graduação, além da elaboração de programas de 
permanente aperfeiçoamento de pessoal" (artigo 27oㅡ, Lei 8080/1990), não concretizou ações que pudessem propor sua efetivação. Apenas nos últimos anos a formação em saúde reativou o debate acerca do pensar agir do trabalhador da saúde, na ótica da educação permanente.

A partir da $12^{\text {a }}$ Conferência Nacional de Saúde (CNS, 2003), a Educação Permanente em Saúde (EPS) passa a ser indicada para a formação e qualificação dos trabalhadores da saúde. É quando o Ministério da Saúde busca desenvolver estratégias para consolidar a formação de seus trabalhadores, que até há pouco era esporádica por meio de cursos de atualização, treinamentos e protocolos, de acordo com a implementação de projetos e programas e recursos específicos, esporádicos e pontuais. O trabalho em saúde compôs um dos dez eixos temáticos dessa Conferência, e a EPS vinculou-se na estratégia central da formação, em decorrência da "[...] necessidade de equacionar os graves problemas do SUS com destaque para a área de recursos humanos e qualidade dos serviços", como analisa Bravo (2006, p.103), porém com pouco êxito. Bravo (2006) aponta a fragilidade das plenárias representadas pela não aprovação do Relatório Final.

Na realidade, a atribuição do Estado para a criação de uma política para a formação dos trabalhadores do sistema público de saúde é citada desde a $8^{\mathrm{a}}$ CNS, de 1986 (Brasil, 2004d, p.14), indicando a “[...] formação dos profissionais de saúde integrada ao Sistema de saúde, regionalizado e hierarquizado". Essa mudança de concepção foi corroborada nas Conferências Nacionais de Saúde subsequentes, que foram realizadas, sistematicamente - 9a

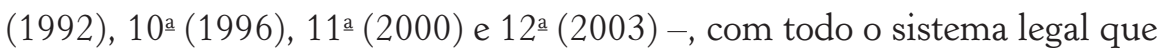
regulamenta o processo participatório e seu funcionamento.

Aliás, a questão relativa ao perfil do profissional da saúde tem referência na Constituição Federal de 1988, no art. 200, onde declara que compete à gestão do SUS “[...] o ordenamento da formação de recursos humanos da área da saúde” (Brasil, 1988, p.40). A atribuição para a formação de seus trabalhadores é indicada também na Lei Orgânica da Saúde no 8.080, de 1990. Desse modo, a educação foi destacada como componente estratégico da gestão no SUS para promover transformações efetivas e interferir na formação, de modo a superar o modelo atual e aproximar o ensino e os serviços, bem como estes à realidade dos usuários.

Desse modo, a criação da Política de Educação Permanente em Saúde como estratégia do SUS para a formação e o desenvolvimento dos trabalha- 
dores para o setor (Brasil, 2004a) segue os ideários da Reforma Sanitária brasileira, na qual o conceito de saúde abarca os determinantes sociais e, a partir dessa compreensão, busca alcançar um nível de qualidade e de humanização no atendimento. A ação de EPS não trata de capacitação ou treinamento, mas da construção de conhecimentos em uma vinculação horizontal, intersetorial e interdisciplinar. Prioriza a relação ensino-aprendizagem movida pelo debate crítico e discussões das exigências presentes no cotidiano dos serviços de saúde, o que significa que o ponto de partida são os problemas ou a problematização da realidade concreta.

A educação permanente é, nessa abrangência, uma estratégia políticopedagógica e parte do pressuposto da aprendizagem significativa, a aprendizagem que produz sentido para o sujeito. A aprendizagem significativa faz a interlocução com os problemas enfrentados na realidade e leva em consideração os conhecimentos e as experiências que as pessoas possuem (Bertussi, 2004). A aprendizagem é incorporada no cotidiano de trabalho "[... ] para efetuar as relações orgânicas entre ensino e as ações e serviço, e entre docência e atenção à saúde, sendo ampliado na Reforma Sanitária brasileira, para as relações entre formação e gestão setorial, desenvolvimento institucional e controle social em saúde" (Brasil, 2004, p.6).

Para que a aprendizagem se torne significativa, a construção do conhecimento passa pela problematização. "Problematizar significa refletir sobre determinadas situações, questionando fatos, fenômenos, ideias, compreendendo os processos e propondo soluções" (Brasil, 2005b, p.8). Ao refletir sobre a situação concreta de trabalho, as propostas de soluções passam a ser mais reais, viáveis e, sobretudo, descentralizadas e compartilhadas.

Os processos de formação e qualificação dos trabalhadores da saúde devem, portanto, se estruturar a partir da problematização das práticas cotidianas e dos problemas - os nós críticos - que impedem a atenção integral e a qualidade do atendimento. Esse processo permite a reflexão do mundo do trabalho e dos problemas vivenciados na área da saúde, sendo que essas dificuldades, ou problemas, são objeto da Política de EPS.

A respeito da metodologia da problematização, Berbel (1998) cita o Método do Arco, de Charles Maguerez, que segundo ela foi apresentado por Bordenave \& Pereira em 1982, utilizando-se de um desenho da realidade em uma escala de cinco etapas, quais sejam: observação da realidade social; pontos-chave; teorização; hipóteses de solução e aplicação à realidade (prática). 
A autora diz que essa é uma alternativa metodológica utilizada em vários cursos e que deve ser apropriada pelo Ensino Superior. Esclarece sua operacionalização ao definir o conteúdo de cada etapa explicando que a primeira, a observação da realidade concreta pelos sujeitos, articula-se a partir de um tema ou unidade de estudo. Os alunos são orientados a olhar atentamente e registrar de forma sistematizada o que perceberem sobre a parcela da realidade em que aquele tema está sendo vivido ou acontecendo, podendo para isso dirigir-se por questões gerais que ajudem a focalizar e não fugir do tema. Essa fase permite que os alunos vejam a realidade de modo diferente que o habitual, pois a proposta da metodologia é identificar as questões que podem ser transformadas em problemas.

Nesse processo, o papel do educador não se restringe a depositar o seu entendimento a respeito do que foi observado, mas especialmente o de discutir com o grupo as constatações efetuadas. Assim, é possível que seja eleito um problema ou mais, mas é importante que todos tenham ciência e envolvimento com o que foi eleito para estudo e discussão. Berbel (1998) sugere a divisão dos discentes em pequenos grupos para facilitar a discussão e a redação da questão a ser problematizada e enfatiza o papel do educador na condução dessa etapa, que será a base para as demais.

A próxima etapa, segunda fase, é a classificação dos pontos-chave. Nesse momento, é importante fazer uso da interrogação, ou seja, procurar a causa dos problemas elencados na fase anterior. A busca das respostas deve considerar a complexidade e a determinação social dos problemas e a sua interferência na saúde. A metodologia prevê que os próprios alunos procurem compreender a relação dos aspectos, nem sempre diretos, " [...] mas que interferem na existência daquele problema em estudo. Tal complexidade sugere um estudo mais atento, criterioso, crítico e abrangente do problema, em busca de sua solução" (Berbel, 1998, p.144). Como se pode perceber, uma fase depende da outra. Em um primeiro momento, é elaborado o problema e, em seguida, busca-se refletir sobre este e sobre as suas causas em um contexto mais amplo. Após essa etapa, o grupo deve fazer uma síntese daqueles pontos que acreditam ser essenciais para aprofundar a reflexão sobre os problemas prioritários a serem trabalhados na próxima etapa. Após esse delineamento proposto, os alunos são estimulados a pesquisá-los teórica e empiricamente. Na sequência, direciona-se para a fase das hipóteses de solução, "[...] construídas após o estudo, como fruto da compreensão profunda que se obteve 
sobre o problema, investigando-o de todos os ângulos possíveis", esclarece Berbel (1998, p.144).

O exercício cognitivo acerca dos problemas e suas possíveis soluções desembocam na quinta fase, a da aplicação à realidade, à prática. É nessa fase, que as decisões tomadas devem ser executadas ou encaminhadas, completando a proposta do Arco de Maguerez, pois tem o sentido especial de "[...] levar os alunos a exercitarem a cadeia dialética de ação-reflexão-ação, ou dito de outra maneira, a relação prática-teoria-prática, tendo como ponto de partida e de chegada do processo de ensino e aprendizagem, a realidade social" (Berbel, 1998, p.144).

Evidencia-se aqui que a implementação da política de EPS privilegiou a utilização da problematização enquanto metodologia eminentemente participativa, considerada inclusiva ao trabalho de campo, implicando no envolvimento pró-ativo de todos os atores sociais (Berbel, 1998; Cyrino \& TorallesPereira, 2004). Essa estratégia, ao ser construída a partir da realidade percebida no dia a dia dos trabalhadores da saúde, tornaria possível o respeito a seus anseios, necessidades e carências, debatidos no coletivo, como o proposto na formação dos trabalhadores da locorregião objeto deste estudo. A ênfase nessa metodologia salienta a contribuição das diferentes práticas na área da saúde, possibilita aos sujeitos interagir com o meio com vistas à sua preparação para a tomada de consciência de seu mundo. Ela tem a finalidade de propiciar a atuação intencional no real e "transformá-lo, sempre para melhor, para um mundo e uma sociedade que permitam uma vida mais digna para o próprio homem”, como reflete Berbel (1998, p.145).

Importa lembrar que Freire (1978) já havia problematizado a questão da educação ao situar o caráter acrítico, autoritário e seletivo da educação. Posteriormente, com a publicação da Pedagogia do Oprimido ${ }^{1}$, reforçou o ponto de vista metodológico da educação libertadora e humanista, a qual deve partir de um processo educativo baseado no diálogo e na participação. Para o autor, o importante nesse processo é que os homens se reconheçam como sujeitos de seu pensar, buscando dialogicamente seu pensar e sua visão do

1 Pedagogia do Oprimido, humanista e libertadora, tem dois momentos distintos. O primeiro, em que os oprimidos vão desvelando o mundo da opressão e comprometendo-se na práxis com sua transformação; o segundo, em que, transformada essa realidade, esta pedagogia deixa de ser do oprimido e passa a ser a pedagogia dos homens em processo de permanente libertação (Freire, 1978, p.41). 
mundo. Freire (1978) questiona também se é possível praticar uma educação dialógica, uma vez que a educação problematizadora é dialogar sobre a negação do próprio diálogo, onde tanto o educador como o educando tornam-se sujeitos do processo.

A problematização, para Freire (1978, p.126), é a "[...] identificação daquelas situações-limites que estão no cerne das contradições da sociedade e que muitas vezes se afiguram aos homens como barreiras insuperáveis”. É, em si, a atitude de compreender e transformar essas "situações-limites" em um novo conteúdo da educação, para superá-las. O objetivo da educação problematizadora, como orienta Freire (1978, p.126), é dar rapidez à ultrapassagem da "consciência real" para a "consciência possível", como de expressão e de criatividade, procurando o melhor caminho que possibilite exercer seu papel de sujeito do conhecimento no processo de sua aprendizagem.

Expressando de outra maneira, na saúde, a educação problematizadora tem como objetivo contribuir na relação entre os sujeitos, de uma postura dialógica, de intercâmbio de informações e de experiências, para o reconhecimento da existência dos saberes distintos, dando um sentido de totalidade e integralidade ao trabalho. As contribuições da prática são, portanto, problematizadas e configuram-se uma forma de estimular o debate e a teorização, em uma relação de constante diálogo educador-educando. Essa exploração temática deve acontecer em um espaço de negação e reafirmação, extrapolando os conteúdos formais já cristalizados no modo de ensino tradicional, transcendendo para a reflexão, construindo o patamar da realidade pensada e levando às proposições de novas intervenções.

Não se trata de um exercício de estímulo de criatividade para a resolução de problemas imediatos, mas de provocação de questionamentos reflexivos sobre as ações e atitudes profissionais cotidianas. Educador e educando veemse como sujeitos políticos, históricos e culturais diante do processo de transformação da realidade que se mostra insatisfatória no atendimento da área da saúde. É importante ter em mente que esse processo - educação permanente - não se finda com um curso, e tampouco se conclui por meio da relação aluno-professor-sala de aula, ele apenas se inicia.

Reafirma-se que a EPS deve se estruturar a partir de elementos concretos da realidade vivenciada e por meio da troca de experiências cotidianas dos atores envolvidos. Destina-se a estimular a construção de novos saberes e práticas, ou seja, não se trata de criar cursos no qual um professor ou um 
coordenador detém conhecimentos e deposita-os nos participantes. Versa, isso sim, da promoção de um processo pedagógico realizado na interlocução e interação do assunto com a realidade, ou da teoria com a prática, constantemente renovado. Assim, os projetos e as ações de EPS devem traduzir as necessidades e as diferenças locorregionais, no paradigma da promoção da saúde, e não do ponto de vista da doença. Devem ser compreendidos como um processo, e não apenas como uma capacitação, visto que envolvem atitudes e habilidades para desenvolver esse contexto dentro do sistema de saúde.

A EPS valoriza a aprendizagem no trabalho, portanto, torna-se necessária a articulação permanente do quadrilátero do SUS - trabalhadores, usuários, formadores e gestores -, para construir compromissos com a transformação do modelo assistencial, com o objetivo de desenvolver a educação para uma atuação crítica e reflexiva visando à integralidade da atenção. Para fortalecer essa concepção, a participação dos diversos atores sociais é fundamental, principalmente para a participação dos trabalhadores da saúde, por estarem diretamente envolvidos com as atividades da prática profissional, partindo dos problemas e das necessidades vivenciadas no cotidiano na busca de melhores soluções para as dificuldades encontradas.

O modelo que se pretende superar entende a educação como um elemento funcional, indo além dos cursos e treinamentos isolados e voltados para problemas imediatos dos serviços. O grande desafio colocado é superar essa tradição.

Na nova concepção, a se construir, o alcance das mudanças desejadas supõe um processo interativo e participativo nas relações cotidianas, principalmente quando marcadas por compromissos éticos, com o melhor acolhimento da população e com a promoção da autonomia dos usuários (Brasil, 2005a, p.43).

O grande diferencial da proposta é a construção coletiva de novas estratégias de trabalho comprometidas com os princípios e as diretrizes do SUS e com as necessidades de cada região mediante a problematização das práticas cotidianas, visando recuperar as ações e desenvolver a autonomia e a participação ativa.

Para a operacionalização do processo, e buscando dar respostas a esses problemas, o Ministério da Saúde criou em sua estrutura a Secretaria de Gestão do Trabalho e da Educação em Saúde (SGTES), que integra o De- 
partamento de Gestão da Educação na Saúde (Deges) e o Departamento de Gestão e da Regulação do Trabalho em Saúde (Degerts). Portanto, com a criação da SGTES, o Ministério da Saúde assumiu seu papel de gestor federal do SUS no tocante à gestão do trabalho e da educação na saúde, competindo ao Deges a responsabilidade pela proposição, incentivo, acompanhamento e elaboração de políticas, em âmbito nacional, nas três esferas de governo.

Em 2003, o Ministério da Saúde, por meio do Deges, apresentou e aprovou, junto ao Conselho Nacional de Saúde (CNS), a Política de Formação e Desenvolvimento para o SUS: caminhos para a educação permanente em saúde e a estratégia de Polos ou rodas de Educação Permanente em Saúde, como instâncias locorregionais e interinstitucionais para gestão da educação permanente (Brasil, 2003a).

O trabalho desenvolvido, conjuntamente com instituições e órgãos representativos da área da saúde, mantém, como informa o Ministério da Saúde (Brasil, 2005), a interlocução permanente com o Conselho Nacional de Saúde, Conselho Nacional de Secretários Estaduais de Saúde (Conass), Conselho Nacional de Secretários Municipais de Saúde (Conasems), Conselhos Profissionais e Associações de Ensino.

A parceria com o Ministério da Educação foi estabelecida para pensar o tipo de profissional desejado na área da saúde e articular as iniciativas de formação e mudanças nos currículos dos cursos e nas práticas profissionais, tendo como objetivo uma formação com perfil que atenda às necessidades do sistema e esteja comprometido com a proposta atual.

As ações e estratégias previstas na Política envolvem as 16 profissões da saúde, reconhecidas pelo Conselho Nacional de Saúde (Brasil, 2005c): biologia, biomedicina, educação física, enfermagem, farmácia, fisioterapia, fonoaudiologia, medicina, medicina veterinária, nutrição, odontologia, psicologia, terapia ocupacional e serviço social; acrescidas de administração hospitalar e saúde coletiva (administração de sistemas e serviços de saúde). O mais inovador é que a atenção sai do foco das profissões tradicionais da área, a medicina e a enfermagem, e se amplia para todas as que compõem os serviços de saúde no SUS. Esse aspecto reforça ainda a interdisciplinaridade e a intersetorialidade.

Desde sua criação, o SUS tem enfrentado problemas que envolvem o acesso e a qualidade do atendimento prestado e comprometem o modelo de aten- 
ção proposto e sua legitimidade. Como caminhos possíveis, o Ministério da Saúde tem promovido o desenvolvimento de métodos de articulação de ações, saberes e práticas para potencializar a atenção integral, resolutiva e humanizada. A formulação de uma política pública apresentada pelo Ministério da Saúde para a educação dos profissionais está, dessa maneira, apoiada nos princípios e diretrizes do SUS.

Nessa referência, a Política de EPS surge como estratégia para a formação profissional, visando superar as deficiências e limitações na formação dos trabalhadores da saúde. Arquitetada como estratégia do SUS, a Política consagra a intenção de consolidar a Reforma Sanitária como resultado de reivindicações coletivas, de instituições e órgãos representativos da saúde pública. Tem como objetivo central a transformação das práticas de saúde, das práticas profissionais e da própria organização do trabalho, para que sejam estruturadas a partir do próprio processo de trabalho. A qualificação da atenção à saúde, das organizações e dos serviços, dos processos formativos e das práticas pedagógicas visa adequar as necessidades e dificuldades do sistema público de saúde.

De acordo com a Política, a integralidade do atendimento é a referência central para orientar as ações de saúde voltadas, ao mesmo tempo, ao indivíduo, à família e à comunidade, em grau de complexidade crescente e nos aspectos preventivo, curativo e de promoção. Sua implementação precisa, portanto, estar articulada aos princípios da intersetorialidade e com equipes multiprofissionais, para romper a formação fragmentada e reafirmar os princípios do SUS.

O caminho adotado pelo Ministério da Saúde para implementar a Política de EPS no País foi a constituição dos Polos de Educação Permanente em Saúde, como instância interinstitucional e locorregional ou rodas - articulação interinstitucional e locorregional - para a gestão colegiada da EPS, com a função de identificar e reconhecer as necessidades de saúde da região e traduzir em uma perspectiva de educação permanente em saúde. O Polo tem como função principal articular e integrar o quadrilátero do SUS, ${ }^{2}$ construir uma roda no SUS para identificar os problemas, as prioridades e as alternativas de formação e de desenvolvimento dos trabalhadores, e progra-

2 O conceito de quadrilátero da formação envolve as instâncias: ensino, gestão, atenção e controle social (Ceccim \& Feuerwerker, 2004). 
mar processos de mudanças que atendam às necessidades dos serviços, podendo, assim, superar o poder hegemônico na saúde.

Os Polos devem ter caráter autônomo e a gestão deve ser exercida de forma colegiada, democrática e participativa, com a inclusão das estruturas regionais e municipais de gestão do SUS, das instâncias de ensino médio e superior (universidades e escolas técnicas), das secretarias estaduais, municipais e instâncias distritais de Saúde e de Educação. O controle social deve participar da definição de diretrizes de sua gestão e fiscalizar as atividades dos Polos, por meio dos Conselhos Nacional, Estaduais e Municipais de Saúde e de Educação (Brasil, 2004B, p.126).

Assim, as rodas devem se efetivar por meio da gestão colegiada, da participação ativa dos gestores estaduais e municipais da saúde e da educação, devendo favorecer a aproximação dos atores sociais do SUS que podem compor os Polos. São eles: instituições de ensino, cursos na área da saúde, escolas e/ou centros formadores, núcleos de saúde coletiva, hospitais de ensino e serviços de saúde, estudantes, trabalhadores, conselhos municipais e estaduais e movimentos sociais ligados à gestão das políticas públicas de saúde (Brasil, 2004a). Além da característica de integração interinstitucional, educação e trabalho, formação e intervenção na realidade, os Polos “[...] são responsáveis, também, pela articulação e gestão da inserção de docentes e estudantes nos cenários das práticas dos serviços de saúde. É a partir deles que se definirão as exigências de aprendizagem" (Brasil, 2005a, p.1).

A EPS destina-se à transformação do modelo de atenção, fortalecendo a promoção e a prevenção em saúde, para que a atenção integral seja a referência do trabalho visando à autonomia dos sujeitos na produção da saúde. Para tanto, conforme analisa Bertani et al.(2008), busca a formação de um profissional crítico, criativo, com capacidade para "aprender a aprender", e que considere a realidade social para oferecer atendimento ético, humanizado e de qualidade, contribuindo para a qualidade do atendimento.

Como eixos norteadores para esses processos de mudança, a Política apresenta a articulação do quadrilátero do SUS: ensino-serviço-gestão-controle social. Ceccim \& Feuerwerker (2004, p.5) esclarecem que a importância do "quadrilátero da formação" (grifo dos autores) tem-se pela relevância da integração, podendo ser uma experiência inovadora com a finalidade de aproximar a formação dos trabalhadores das reais necessidades de saúde. Os auto- 
res refletem que compete tanto ao SUS quanto às instituições formadoras "[...] coletar, sistematizar, analisar e interpretar permanentemente informações da realidade, problematizar o trabalho e as organizações de saúde e de ensino, e construir significados e práticas com orientação social [...]" (Ceccim \& Feuerwerker, 2004, p.5).

A articulação do quadrilátero do SUS indica um processo de alargamento de parcerias que ampliem a corresponsabilidade social, a troca de experiências, o reconhecimento das práticas desenvolvidas nos serviços de saúde, entre outras ações que aproximem e estimulem a participação ativa dos atores sociais da saúde. São reconhecidos como atores sociais os cidadãos, as instituições e os grupos sociais envolvidos na saúde "[...] que participam, organizadamente, da formulação, da gestão, planejamento e monitoramento e controle social do SUS, interferindo técnica, política ou eticamente no processo participativo" (Brasil, 2006b, p.38).

Dessa perspectiva, a formação na área da saúde deve considerar não apenas as exigências dos postos de trabalho do setor saúde, que seguem as orientações do mercado e que exigem cada vez mais um trabalhador treinado e preparado para a produção e reprodução do capital. O trabalho na saúde, como alertam Ceccim \& Feuerwerker (2004, p.7), "[...] é um trabalho de escuta, em que a interação entre profissional de saúde e usuário é determinante da qualidade da resposta assistencial”. A área da saúde requer educação permanente, uma vez que "a incorporação de novidade tecnológica é premente e constante, e novos processos decisórios repercutem na concretização da responsabilidade tecnocientífica, social e ética do cuidado, do tratamento ou do acompanhamento em saúde".

As diretrizes indicadas para operacionalizar esse processo compreendem a identificação de necessidades e de possibilidades para desenvolver a formação dos trabalhadores da saúde e a capacidade resolutiva dos serviços. Envolve, na mesma amplitude, o desenvolvimento da educação popular com ampliação da gestão social sobre as políticas públicas, reconhecendo as necessidades de saúde de cada região e traduzindo-as na perspectiva de educação permanente.

Nessa perspectiva, a lógica da Política de EPS é descentralizadora, ascendente e transdisciplinar, visando ao desenvolvimento da autonomia das pessoas, à descentralização da gestão, à participação e à mudança do modelo de assistencial centrado na doença e nos procedimentos fragmentados que 
valorizam as especialidades. Propõe a ruptura do sistema verticalizado na saúde, em que alguns detêm o saber e o poder, para trabalhar com um conjunto articulado de serviços básicos, de especialidades e hospitalares, em que todas as ações de saúde devem ser prestadas reconhecendo as necessidades das pessoas envolvidas (Brasil, 2004a).

Cabe aos atores do SUS diretamente envolvidos com as ações de assistência realizá-las de forma integrada e humanizada, considerando as subjetividades, acolhendo as necessidades dos usuários para dentro dos serviços de saúde e respeitando sua história de vida, seus sentimentos, incertezas, conflitos e medos. A equipe de saúde, ao estabelecer uma relação horizontal com a população, permite que esta participe de todo o processo que envolve seu tratamento. Esse paradigma desenvolve a capacidade crítica de reinventar o trabalho e encontrar a melhor solução para os problemas apresentados. $\mathrm{O}$ usuário não fica passivo, sendo reconhecido enquanto sujeito que pensa, age e é responsável por todos os seus atos, e também participa com a equipe de saúde de todas as decisões que envolvem sua vida.

Um processo de educação permanente é profundamente democrático, como assinala a Opas (Rovere, 1994), pois implica começar a aprender a perguntar, e não a estabelecer respostas prontas. É um processo que só pode se sustentar sobre a base de um trabalhador que é sujeito de seu processo de trabalho, ainda que isto contradiga a cultura dominante dos serviços de saúde. Por isso, a EPS demanda organizações mais democráticas e a construção de espaços que possibilitem a reflexão.

Entretanto, exercitar esse processo na saúde é um desafio para os atores sociais do SUS na construção de relações que busquem a ruptura com as práticas conservadoras e autoritárias. É fundamental a construção de dispositivos institucionais que estimulem a disponibilidade para estabelecer estruturas mais democráticas e participativas. É quando a educação (popular) em saúde é um caminho para trabalhar a decodificação dos conceitos com a população, facilitar a conversa, o diálogo com a apropriação popular dos termos técnicos para a população. Do mesmo modo, a equipe de saúde deve valorizar as potencialidades e habilidades que a população tem na vida pessoal, que não são técnicas, e podem ser trazidas para as unidades e serviços e enriquecer o trabalho, para melhorar a condição da própria saúde.

A valorização dessas competências quebra a rigidez que existe nessa área e coloca em evidência os valores e princípios éticos que devem fundamentar 
o trabalho na saúde. O exercício da liberdade e o desenvolvimento da autonomia na relação da população com a equipe de saúde colocam o usuário em evidência e reconhecem seu direito de escolha e de opção. Humanizam a relação em saúde, resgatam o respeito à vida humana e, principalmente, o respeito à pessoa como ser integral.

Dessa maneira, na análise dos processos de trabalho na saúde na perspectiva totalizante, são considerados os determinantes técnicos, operacionais e organizacionais, mas também os determinantes de caráter econômicos e produtivos, físicos e ambientais, históricos e sociais, culturais e políticos. A construção do saber realmente significativo implica uma reflexão sobre a competência em uma dimensão humana e social, isto é, para além de uma característica própria do sujeito ou abstrato.

Para completar o pensamento proposto, cabem aqui as palavras de Freire (1978, p.127), que orienta a comunicação não como mero instrumento de sociabilidade, mas como instrumento de trabalho que conduz a socialização: "Não é no silêncio que os homens se fazem, mas na palavra, no trabalho, na ação-reflexão. Mas, se dizer a palavra verdadeira, que é trabalho, que é práxis, é transformar o mundo, dizer a palavra não é privilégio de alguns homens, mas direito de todos os homens".

\section{Os desafios para a formação na locorregião de Franca/SP}

Nós fomos motivados a participar desse processo educativo. [...] mas ficou centrado em alguns funcionários, e isso tem prejudicado. Fica sempre centrado em algumas pessoas. Então, eu acredito que o grande desmotivador é que faltou apoio da gestão, porque a dificuldade vai ser comum, a gente vai ter que enfrentar dificuldades e obstáculos. E eu acredito que tem que ter engajamento nessa parte do gestor também. [...] Se não tiver, dificulta. Pode acontecer, mas desenvolve muito lentamente. (S1)

Quando eu fui chamada pra participar daquele processo de facilitadores, de ser um facilitador, eu não tinha a mínima noção do que se tratava, entendeu? [...] Mas ele (gestor) também não sabia nada, não entendia nada. [...] Como eu sempre fui uma pessoa que gosta de trabalhar na saúde pública, eu me interessei [...]. Então, eu achei que nesse sentido foi meio perdido, porque indicaram um pessoal que nem conhecia o processo e o objetivo do curso. Eu achei que se per- 
deu muito da proposta do Ministério por conta disso. E por quê? Porque foram pessoas que não tinham nada a ver com o trabalho, com o serviço, tinha gente lá que hoje nem está mais no serviço público. [...] Eu acho que tinha que acontecer uma mobilização, municipal, regional, começar a falar disso nas Secretarias, mobilizar nas Regionais de Saúde, trazer esses profissionais pra saber um pouco mais dessa proposta, pra depois levar para um curso de formação. [...] Eu não tive muito contato com outras Regionais, mas o que percebi, por exemplo, Araraquara, eu achei que já estava muito mais articulada nesse processo, porque as pessoas que foram lá participar desse Curso de Formação, elas já faziam parte do Polo, que eram as rodas de discussões. Então lá foram pessoas que já estavam engajados com essa proposta. Franca, eu senti que ninguém estava engajado com nada, que nem estava acontecendo muito bem essa questão do Polo, eu nem conhecia, nunca tinha ido numa reunião do Polo. [...] Chamaram pessoas que não tinha nada a ver, por isso a proposta era formar sete mil facilitadores, e conseguiram apenas três mil. Acredito que... como no meu grupo, foram pessoas [...] que nem estavam aí, não eram profissionais de carreira, estavam lá como provisório, e foram nesse processo, eu acho que isso falhou. Porque realmente quem ficou e quem terminou foram as pessoas que estavam já engajadas no processo de trabalho, nessa proposta, e que identificaram com a proposta. Isso poderia ser diferente, rever esses conceitos de chamar as pessoas que estão mais articuladas com essa proposta. (S2)

Quando fui chamada pra participar, eu nem sabia o quê que era. Eles explicaram que era treinamento que a gente ia fazer. Que era sobre atendimento, a melhoria no atendimento, e a gente foi assim, sem saber realmente o que era mesmo. [...] Eu achei que a maioria estava lá realmente sem saber o que era. Mas foi bom. Eu gostei. [...] É, a gente tentou participar, o máximo. [...] Penso assim, eu acho que não teve uma continuidade, não é? Não teve mais cursos pra formação de outros profissionais, isso que eu acho. [...] Sinceramente eu não sei por que não. Não sei se eles acharam que não tenham alcançado o objetivo, ou se foi realmente cortado pelo SUS. [...] Não fui mais convidada pra nenhuma reunião. [...] Pelo menos não chegou até mim. (S3)

Porque muita gente entrou pensando que era um congresso [...]. , lá em Serra Negra, ficar 3 dias e pronto. [...] Então, eu acho que muita gente entrou nessa achando que era mais um cursinho: vou lá, faço presença e vou embora. Eu sabia que não era, que era um curso, que era um estudo a distância. [...] Eu fui orientada. Eu já sabia disso. Se eu ia fazer mesmo, continuar, era outros quinhentos. Mas eu, igual eu te falei, eu vou até o fim, eu não gosto de começar e parar. E os outros? Eu acho que parou por falta de tempo mesmo. [...] Muito 
longo, foi uma coisa muito desgastante. [...] Igual, tinha lá, nunca participei de nenhum curso a distância. Eu achei que teve uma parte que ficou a desejar. O material era bom. Dá pra usar. Nossa, eu uso muito! É muito bom. Mas tem essa parte aí, sabe? De acesso na internet. Às vezes, não tava em rede, você ia acessar, não entrava, o chat, não é? [...] Não conseguiram organizar. É muito, o Brasil inteiro é complicado. (S4)

Das falas emerge a análise das perspectivas dos sujeitos quanto à Política de Educação Permanente em Saúde (EPS), o processo de implementação das ações na locorregião e a integração e participação dos atores sociais no Polo do Sistema Único de Saúde (SUS). Buscou-se considerar, nesse processo, a construção da roda para identificação dos problemas prioritários de formação e a seleção dos facilitadores de educação permanente em saúde, o que remete aos questionamentos do reconhecimento da EPS, do significado da formação para o desenvolvimento das ações de educação permanente, e a aplicação prática do conhecimento do uso da metodologia da problematização recomendada e/ou utilizada visa ao compromisso para a construção do processo pedagógico e político na locorregião.

O diagnóstico locorregional, proposto pela Política de EPS, é fundamental para identificar necessidades e prioridades e sugerir soluções adequadas à realidade de cada estado brasileiro, suas locorregiões e municípios. A diversidade do Brasil, expressa na cultura, política, educação, economia, na condição social da população, faz dessa Política um caminho para que a própria sociedade encontre as melhores soluções para os problemas da saúde.

A ação desencadeada a partir de 2003 pelo Ministério da Saúde conseguiu compor, segundo Maria S. Oliveira (2004), 93 Polos de Educação Permanente em Saúde no País, com a participação em média de 1.030 instituições representativas. O envolvimento e a participação de várias instituições e entidades representativas da saúde na composição dos Polos do SUS são avanços significativos do processo, ilustrados no quadro a seguir.

Observa-se que, no período de um ano, o Ministério da Saúde, por meio da Secretaria de Gestão do Trabalho e da Educação em Saúde (SGTES) e do Departamento de Gestão da Educação na Saúde (Deges), conseguiu desencadear um processo de articulação interinstitucional no País com uma representatividade expressiva. 
Número de Polos constituídos no País

Instituições de Ensino Superior

Gestores Municipais

Gestores Estaduais

Instâncias de Controle Social

Escolas Técnicas de Saúde

Serviços de Saúde

Movimento Estudantil

Entidades de Trabalhadores de Saúde $\quad 43$

Movimentos Sociais $\quad 41$

Outros 41

Número Total de Instituições/Entidades/Participantes

Quadro 3 - Demonstração da composição do número de Polos constituídos no País. Fonte: Oliveira (2004).

No Estado de São Paulo, essa organização abrangeu oito Polos, distribuídos nas seguintes locorregiões: Nordeste, Leste, Noroeste, Vale do Paraíba, Sudoeste, Oeste, Grande São Paulo e Baixada Santista. O Polo de EPS do Nordeste Paulista abrange três locorregiões, organizadas pelos Departamentos Regionais de Saúde (DRS) de Araraquara, Franca e Ribeirão Preto.

O DRS VIII da locorregião de Franca/SP tem seus 22 municípios representados no Polo do Nordeste Paulista pelo Conselho Técnico Pedagógico do Núcleo de Franca, com a responsabilidade de avaliar e aprovar o financiamento de ações e projetos para formação e qualificação específica na área da saúde, bem como cursos de extensão, especialização, planejamento e gestão, fundamentados na EPS.

Respeitando-se a diretriz de descentralização, regionalização e participação do SUS, coube ao Polo da locorregião, juntamente com o Conselho Técnico, desenvolver estratégias para a construção de um conhecimento significativo e crítico para a formação dos atores do SUS. A forma de participação nesse colegiado foi definida pela própria Portaria que o criou com autonomia para composição de elementos representativos da realidade de cada local e da região, compreendendo que essa forma articula e integra representantes de cada órgão de saúde dos cursos profissionalizantes das universidades aí instaladas e da sociedade em geral. 
Deste modo, é na construção dessas relações, baseadas em uma prática democrática e dialógica, transformadora, que os sujeitos são motivados a experimentar uma maneira diferente de ver o mundo e a própria saúde. $\mathrm{O}$ colegiado é um espaço - intersetorial e interdisciplinar - que permite colocar os atores sociais do SUS como sujeitos do processo de aprendizagem, em uma postura crítica e ativa para reflexão dos problemas que envolvem a saúde locorregional.

Para dar início à implementação da Política de EPS e garantir a observância da utilização da metodologia de trabalho recomendada, foram realizados na Secretaria Estadual de Saúde, em São Paulo, seminários de preparação restrita a alguns representantes do Polo Nordeste Paulista.

No sentido de operacionalizar a proposta, alicerçada na aprendizagem significativa, uma das estratégias adotadas foi a atuação de facilitadores de educação permanente em saúde cujo papel é, justamente, facilitar a reflexão crítica sobre o processo de trabalho das equipes que operam o SUS, capaz de problematizar e identificar pontos estratégicos para a produção da integralidade.

A indicação para escolha dos facilitadores, articulada por meio dos Polos, deve partir da discussão ampliada dos problemas ${ }^{3}$ locorregionais que vêm impedindo a construção do cuidado integral em saúde. Com essa articulação, é possível identificar os problemas a partir da compreensão do modo como as atividades cotidianas são operadas nos serviços. É desse contexto problematizador que os facilitadores são identificados: ator central implicado no problema prioritário e os temas a serem trabalhados nas primeiras iniciativas de educação permanente (Bertussi, 2004).

A formação dos facilitadores de EPS realizou-se com a gestão política do Deges, do Ministério da Saúde, e a gestão pedagógica e administrativa da Escola Nacional de Saúde Pública (ENSP/Fiocruz). A Educação a Distância (EAD) foi uma opção política e pedagógica e um processo informal de

3 A orientação do Ministério da Saúde envolvia as seguintes questões: "Quais os principais problemas que nos afastam da atenção integral neste dado território/locorregião? Identificados os problemas, o exercício é descobrir quais os mais críticos, ou seja, quais os que enfrentados possibilitam um salto de qualidade? Definidos os "nós críticos", teremos localizados temas, equipes, locais geográficos, locais de atenção nos quais prioritariamente desenvolveremos ações de educação permanente. O passo seguinte é identificar pessoas com potencial para conduzir esses processos de reflexão crítica" (Brasil, 2004a, p.7). 
aprendizagem, considerada como a maneira mais democrática de atingir as pessoas nas diversas regiões do País, onde o aluno é o sujeito de seu projeto de aprendizagem, acompanhado pelo tutor, que também está em formação e que contribui nessa perspectiva para a construção coletiva do saber.

Bertussi (2004) esclarece que os tutores ${ }^{4}$ são também facilitadores, articuladores de processos coletivos para apoiar a formação político-pedagógica dos facilitadores. A formação dos facilitadores de EPS foi um processo massivo desencadeado no País, que pretendia inicialmente formar 6 mil facilitadores em um período, previsto inicialmente, de quatro a cinco meses de duração, e ao mesmo tempo, pretendia com o curso apoiar o desenvolvimento de ações de educação permanente nas diversas regiões do país.

A metodologia adotada possibilitou a formação de uma rede nacional de 367 facilitadores de educação permanente em saúde, sendo 43 da região Norte, 37 da Centro-Oeste, 48 da Sul, 104 da Sudeste e 135 da região Nordeste.

O estado de São Paulo trabalhou com 40 tutores e o Polo Nordeste Paulista com 5 tutores. As vagas pactuadas no Conselho Estadual de Secretários Municipais de Saúde (Cosems) para a locorregião de Franca (DRS VIII) foram: 1 tutor e 22 facilitadores (Oliveira, M. S., 2004).

Pensar e construir um processo de base locorregional, com objetivos nacionais, foi e tem sido um grande desafio para o SUS, considerando que este processo ainda está em andamento nos estados e municípios. Importa, assim, esclarecer que os dados e percepções aqui apresentados são prioritariamente produtos do primeiro momento de estruturação nacional da estratégia proposta.

A roda instalada ${ }^{5}$ para a discussão ampliada e identificação dos problemas que impedem a atenção integral na locorregião de Franca/SP contou com a participação em média de 130 atores - trabalhadores, estudantes,

4 Os tutores foram selecionados por meio de processo público em novembro de 2004, com inscrição autorizada pelos Polos e avaliada mediante critérios de identificação e compromisso com a Política, a capacidade de articulação locorregional e experiência prévia em facilitação de processos coletivos. Em dezembro de 2004, foi iniciada a Formação dos Tutores, para a operacionalização do Curso de Formação de Facilitadores de Educação Permanente em Saúde, que teve início em março de 2005.

5 A primeira Oficina, realizada em 22/2/2005, teve a participação de 104 atores: 51 trabalhadores, 30 estudantes, 12 gestores, 8 docentes e 3 usuários. Em 8/3/2005, aconteceu a segunda Oficina para discussão ampliada dos problemas e identificação dos "nós críticos" que afastam a locorregião da atenção integral e indicação de facilitadores para o Curso. A roda 
gestores, docentes e usuários. Foi realizada em dois momentos: a primeira Oficina contou com representante do Ministério da Saúde e teve a participação de 104 atores sociais. Foi um momento para conhecimento da Política de EPS e do próprio processo e construção de um diálogo intersetorial.

A segunda Oficina foi realizada para a discussão ampliada dos problemas e identificação dos "nós críticos" que afastam a locorregião da atenção integral, e teve também a responsabilidade de identificar e indicar os facilitadores de educação permanente em saúde. Contou com a participação de 25 atores sociais, sendo a maioria gestores.

Esse momento demonstrou as dificuldades do Polo da locorregião de ampliar a participação e a integração dos atores sociais, o que está explicitado nas falas dos sujeitos: "[...] ficou centrado em alguns funcionários, e isso tem prejudicado" (S1); "[...] não tinha a mínima noção do que se tratava” (S2); “[...] nem sabia o quê que era. Eles explicaram que era treinamento que a gente ia fazer" (S3) e, "[...] ficou centrado em algumas pessoas novamente" (S4).

Os problemas identificados na locorregião de Franca foram organizados pelos atores participantes em três eixos de atenção: formação, assistência e gestão; apontando-se para as soluções na descrição final. A roda ressaltou que todos os problemas estão relacionados entre si e ligados diretamente ao modelo de atenção, à (des) humanização do atendimento e falta de acolhimento na rede proposta pelo SUS, principalmente de integralidade na atenção à saúde, indicando que a formação deve orientar as mudanças de paradigma e sustentar a resolução dos demais problemas, inclusive de gestão, pela análise de Sarreta \& Bertani (2006).

A metodologia recomendada, apesar de instigante e participativa, é de difícil operacionalização por exigir uma nova postura pedagógica, o que resultou em restrita repercussão prática entre os membros do Polo e do Conselho Técnico Pedagógico. Não se nega aqui sua importância como instrumento de trabalho, mas muitas dúvidas surgiram e ficaram sem respostas, e sua utilização não foi completamente compreendida e/ou utilizada no âmbito a que passou a se destinar.

teve a participação de 25 atores, entre eles, 12 gestores da locorregião, 7 representantes da DRS VIII, 5 representantes do Conselho Técnico Pedagógico e 1 representante de usuários, não contando com representantes de trabalhadores e/ou instituições formadoras, além dos que estavam representando o Conselho Técnico Pedagógico. 


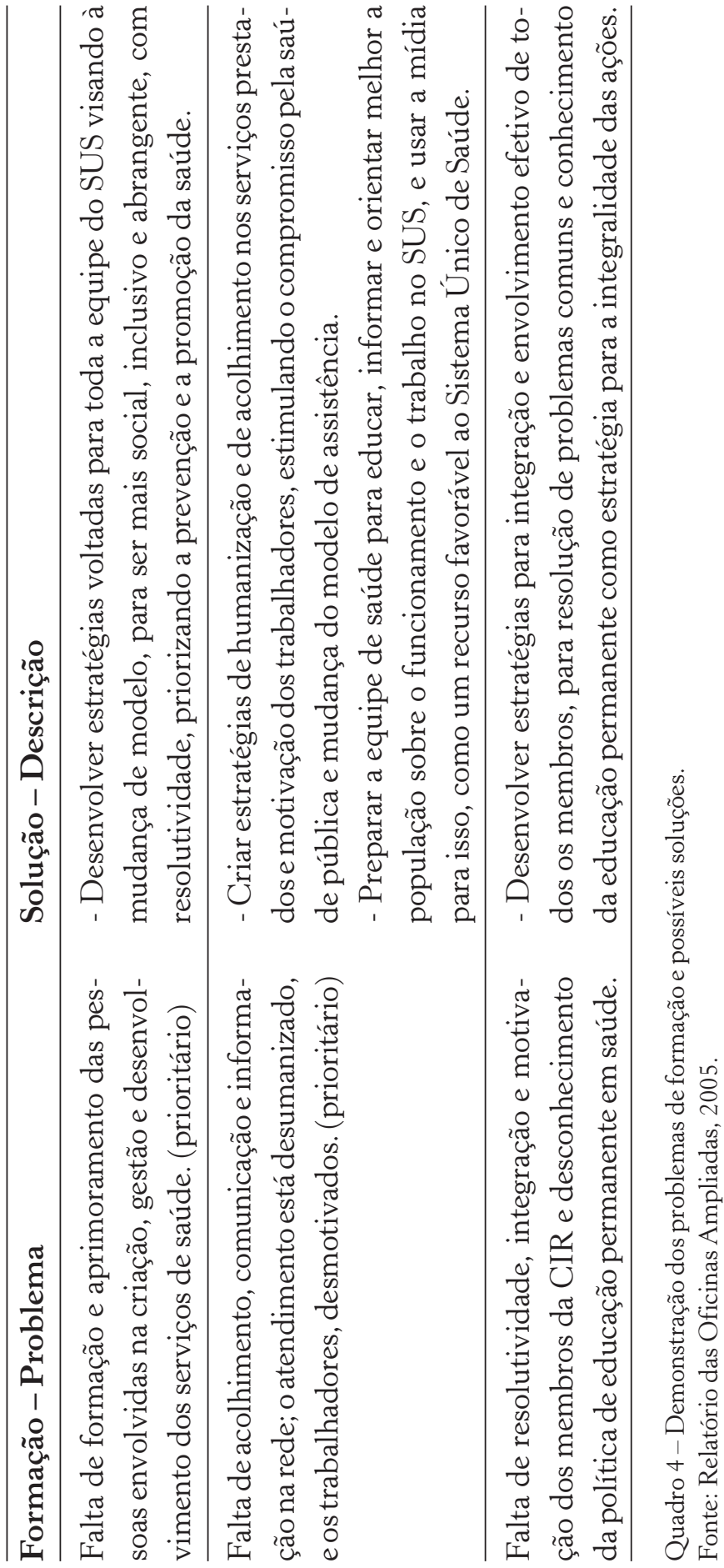




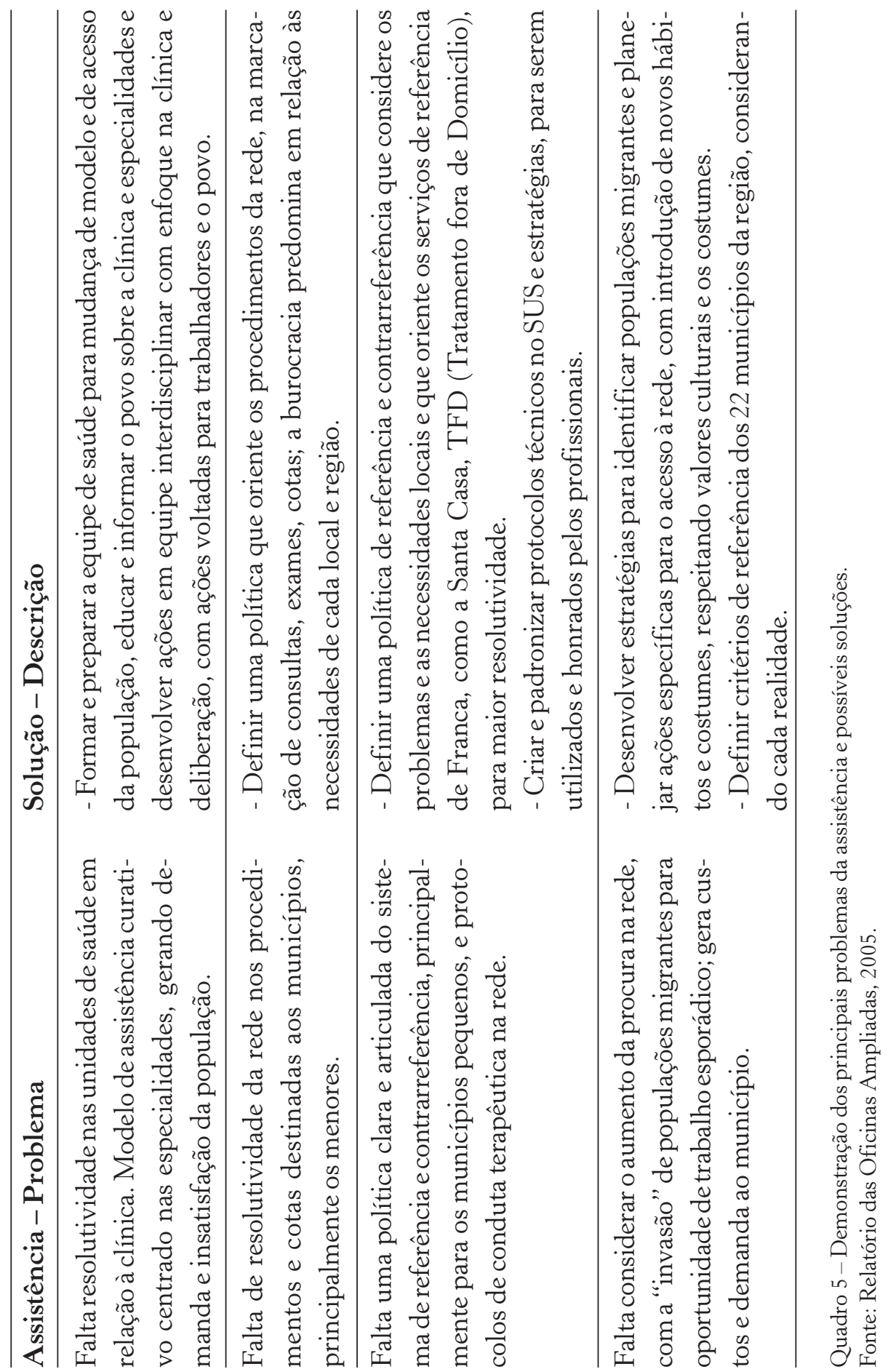


Os quadros a seguir foram elaborados visando à sistematização das informações dos problemas identificados para subsidiar a organização dos cursos, ou seja, as ações de educação permanente, na locorregião. Observase que a formação profissional fragmentada e distante do perfil adequado para o trabalho, na saúde pública, manifesta-se em desconhecimento sobre o funcionamento do SUS, ou seja, de seus princípios, suas diretrizes e estratégias de organização, com atendimento desumanizado e desprovido de acolhimento.

Já os principais problemas da assistência, descritos a seguir, estão vinculados ao modelo curativo verticalizado, centrado no médico e nas especialidades clínicas, com deficiência nas ações preventivas e na resolutividade da rede de saúde, especialmente em relação aos procedimentos de baixa complexidade. Observamos a inexistência do sistema de referência e contrarreferência e de protocolos técnicos para conduta terapêutica, ou do cumprimento destes por parte dos profissionais.

Em relação à gestão do SUS, a roda identificou a ausência de uma política estabelecida para implementação, manutenção e compromisso das equipes de saúde da família e enfoque na atenção básica. Faltam estratégias políticas fundamentadas em ações técnicas; há muita interferência de grupos políticopartidários nas ações e no funcionamento do SUS, e nota-se, ainda, a ausência de diretrizes que orientem a contratação de recursos humanos.

A construção desse processo, na locorregião de Franca, analisada por Sarreta \& Bertani (2006), evidenciou que, mesmo considerando a construção coletiva dos atores da saúde no levantamento dos eixos prioritários de atenção, o aspecto da participação como instrumento do processo educativo não se deu facilmente desde sua primeira colocação, e nem ao menos era notado nas reuniões do Polo e do Conselho Técnico Pedagógico.

Muitas vezes, persistia certa percepção de "não pertencimento" para alguns membros, e mesmo o sentimento de "inadequação" no andamento dos trabalhos. Do mesmo modo, a roda evidenciou em sua construção, dificuldades de exercitar o diálogo e estabelecer relações mais democráticas, aspectos imprescindíveis para a implementação da Política e da educação permanente em saúde. Durante as reuniões nesses espaços, era comum haver os que de tudo eram informados e tinham condições de decidir e os que, de certa forma, podiam ser apelidados de "espectadores", pois não conseguiam acompanhar os debates ou ao menos compreender completamente as deci- 


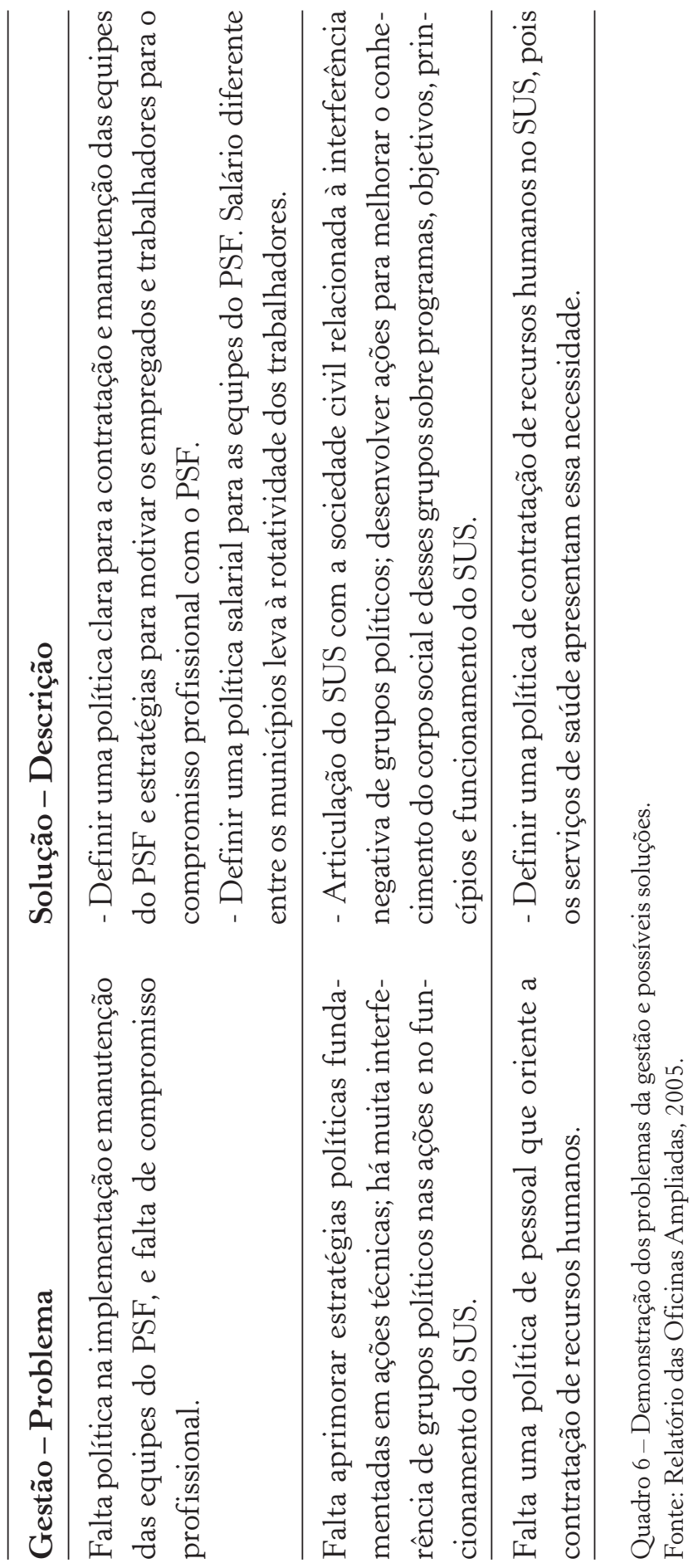


sões finalizantes que os amarravam. O usuário dos serviços de saúde, muito frequentemente, é representado como figuração, sem que suas opiniões tenham um rebatimento expressivo no andamento das discussões o que, aos poucos, pode afastar o interesse na participação.

Wendhausen \& Caponi (2002), ao explanarem acerca do poder do discurso de quem detém o conhecimento, no estudo realizado no estado de Santa Catarina a respeito do processo de participação no conselho de saúde, detectam um silêncio em torno dessa ação, principalmente dos usuários, sugerindo que se pense nesse aspecto mais como um silenciamento.

De maneira geral, os Polos, no dizer de Gastão Campos (1997), caracterizam-se mais como espaço de autoritarismo e exclusão do que de exercício de práticas democráticas e de inclusão. Acredita-se mais na informação dos dados epidemiológicos de cada subárea acrescida dos relatos dos gestores do que se aceitam a opinião popular, o senso comum, a experiência vivida dos sujeitos na saúde e os relatos dos profissionais interessados em implementar o Sistema Único de Saúde.

A proposta da educação permanente em saúde foi traduzida no Conselho Técnico Pedagógico da locorregião de Franca como necessidade de desenvolvimento de diversos cursos aos profissionais da saúde, com vistas a melhorar o desempenho técnico-operacional de inter-relacionamento funcional e de atendimento ao público, o que resultou em avanços e ganhos. Entretanto, a locorregião não conseguiu implementar um processo participativo com potencial transformador e estratégico da EPS. De atitude passiva, até pouco comprometida, o processo poderia ser provocado pela metodologia proposta ao desenvolver uma postura mais ativa e crítica na problematização das dificuldades que envolvem a saúde, as quais levariam ao surgimento de novas competências e habilidades, propostas e soluções.

É preciso lembrar que a formação proposta pela Política está na contramão do modelo hegemônico de formação, uma vez que objetiva dinamizar coletivos e a reflexão crítica sobre o modo de pensar e fazer saúde. O que certamente influenciou no processo desencadeado para formação dos facilitadores, proposta pelo Ministério da Saúde, como um caminho democrático para implementar a Política no País, fortalecendo o município e a região.

Um aspecto que evidencia essa análise pode ser verificado no resultado da proposta desenvolvida pelo Ministério da Saúde na locorregião de Franca: dos 22 facilitadores indicados para a realização do Curso de Formação de 
Facilitadores de Educação Permanente em Saúde, somente nove participaram ativamente e concluíram as atividades. Treze desistiram da formação. Mesmo considerando que o processo envolveu dificuldades que incluem não só a maneira como as pessoas foram indicadas, o uso dos recursos tecnológicos, o desconhecimento da proposta, a falta de informações, a exigência do tempo no cumprimento de prazos, como também a oportunidade de formação não foi predominante.

Nota-se que, dos principais problemas identificados pela roda, os quais afastam da atenção integral, os "nós críticos" e as possíveis soluções representados nos quadros anteriormente foram priorizados: a formação e aprimoramento das pessoas envolvidas na criação, gestão e desenvolvimento dos serviços de saúde, indicando este último para toda a equipe do SUS visando à mudança de modelo, para ser mais social, inclusivo e abrangente, com resolutividade, priorizando a prevenção e a promoção da saúde.

A partir desse exercício, seriam indicados os facilitadores da educação permanente, pessoas com potencial para acompanhar as ações de educação permanente na locorregião e facilitar a reflexão crítica sobre os processos de trabalho das equipes que operam no SUS. Pode-se verificar nas falas dos sujeitos que esse processo não foi desenvolvido, como relata um sujeito: "[...] em Franca, eu senti que ninguém estava engajado com nada, que nem estava acontecendo muito bem essa questão do Polo, eu nem conhecia, nunca tinha ido numa reunião do Polo. [...] Chamaram pessoas que não tinha nada a ver [...]" (S2).

Outro aspecto dessa centralidade referida que chama a atenção é a desistência dos treze facilitadores do Curso de Formação do Ministério, provavelmente relacionada a vários fatores, como o tipo de escolha de facilitadores, que não tiveram informação e esclarecimento adequados da proposta e de quem não foi considerado o perfil profissional, e, além disso, não houve o apoio necessário para a formação e o desenvolvimento das ações de EPS identificadas na roda do Polo da locorregião, conforme estava pactuado.

Destaca-se que os compromissos indispensáveis para a formação de facilitadores de EPS são os seguintes: os Polos devem assegurar as condições técnicas necessárias para a participação dos facilitadores em um curso a Distância; identificar temáticas e áreas prioritárias para iniciar experiências de educação permanente; assegurar apoio coletivo para o desenvolvimento das experiências. Ou seja, "a participação no curso não pode ser uma decisão 
individual: tem que ser fruto de decisão, compromisso e construção coletivos" (Oliveira, M. S., 2004, p.4).

Importa esclarecer algumas questões, tais como: a orientação de que a formação deveria estar vinculada ao horário e local de trabalho não era clara. Enfim, ficou a critério de cada gestor o funcionamento do processo, mas na verdade a responsabilidade ficou centrada nos facilitadores como opção pessoal, e alguns facilitadores não dispunham de recursos de acesso à internet. "Muita gente desistiu até por questão da internet. Acho que isso desanima, se perde, perde a credibilidade da situação" (S2). Da mesma forma, não houve acompanhamento por parte do Conselho Técnico Pedagógico do Polo da locorregião no processo da formação dos facilitadores de EPS.

Ao fazer a associação com o modo de escolha dos atores sociais para a atuação como facilitadores de EPS, verifica-se que os critérios não foram definidos e nem ao menos estavam claros ou foram divulgados. Compreende-se que nesse processo, foi considerado o relacionamento com coordenadores ou gestores, ou mais explicitamente a aproximação e o estabelecimento de laços de amizade e simpatia e até admiração profissional entre eles. Sublinha-se, assim, um aspecto a ser considerado para o exercício de atividade em serviço público por meio de indicação.

Nesse aspecto, a orientação para implementação da Política por meio do Polo da locorregião era desenvolver ações descentralizadas, para facilitar o acesso das pessoas e a análise da própria realidade. Contudo, a falta de incentivo não foi entendida pelos coordenadores e responsáveis pelo processo como decisiva para a desistência dos facilitadores de EPS. Nota-se quanto o precário estímulo por parte das Prefeituras ou Secretarias de Saúde fez sentir-se no processo de implementação da Política de Educação Permanente em Saúde, promovida aos trabalhadores da saúde. Ao tornarem-se parceiros dessa Política, esses órgãos públicos deveriam dar sustentação aos funcionários, o que nem sempre aconteceu.

Pôde-se observar também que alguns mecanismos empregados para a seleção dos facilitadores de EPS foram certamente baseados em seu desempenho e sua competência profissional, mas dificilmente definidos com critérios claros. Esse fato sustenta o discurso da escolha baseada no relacionamento interpessoal e no vínculo de amizade. Deste modo, ainda que o perfil profissional dos entrevistados - os trabalhadores da saúde - mostre que são atuantes dentro do SUS, dos quatro indicados para a formação, três desconheciam a proposta. 
Portanto, o que as entrevistas demonstraram é que não houve processo participativo e integrado para o desenvolvimento das ações na locorregião. Os participantes do Conselho Técnico Pedagógico, na posição de gestores ou de responsáveis pela implementação do processo, sentiram-se, inclusive, no direito da autoindicação. Na prática, entretanto, a educação permanente e sua potência não são conhecidas pela maior parte dos trabalhadores. Existe uma profunda heterogeneidade entre os diferentes atores em sua capacidade de operar no campo da educação (recursos de formação, pessoal disponível, possibilidades de parceria), conforme Oliveira (2004) já havia observado.

Outro aspecto destacado, a descontinuidade administrativa, provocada pela diferença partidária no poder, reflete-se até no nível direto de atenção nas unidades básicas de saúde. Essa situação pode ser observada no relato de dois sujeitos que passaram a enfrentar dificuldades com a mudança administrativa local e a falta de apoio dos gestores. O reflexo no andamento do curso realizado por deliberação do Ministério da Saúde, a partir do diagnóstico das dificuldades de implementação definitiva do SUS, está comprovado nos relatos dos sujeitos.

Então, é o que te falei: como eu tive esse problema lá em cima (mudança de prefeito), eu fui meio que cortada, você entendeu? Me deixaram de lado. Então eu não tive muitas chances, mas o que eu podia passar pra alguns funcionários aqui eu tentei. [...] Aqui, a gente, na unidade, a gente é uma equipe boa, equipe menor. Tem (grupo de gestante), mas não participo [...]. Justamente porque ela (secretária de saúde) não permite. [...] Pelo contrário, o que ela puder me deixar de lado... Não, nunca consegui participar, também nunca fui convidada. [...] Então, porque aqui é ligado a lá também, ela (gestora) que participa de tudo, entendeu? [...] A equipe dela, ela que resolve tudo. [...] Então, talvez, aliás, eu nem sei por que ela é, igual, a gente trabalhava com o outro secretário. Não sei se ela ficou, assim, com receio de alguma coisa. [...] Não é pessoal, não. Não tenho problema pessoal. [...] Não consegui fazer as coisas totalmente, não. [...] Como foi proposto, não. É, foi mais nesse sentido que eu te falei, em termos de, da gente sentir o que o usuário necessita, entendeu? (S3)

A falta de diálogo e de estabelecimento de prioridades voltadas às necessidades diagnosticadas da área refletiu-se no desrespeito ao trato com os trabalhadores da saúde. Assim, é importante ressaltar que não se destaca somente se a questão da participação desvinculada da realidade em que esta se dava. 
Durante a programação da formação dos facilitadores de EPS, observouse no Conselho Técnico Pedagógico a argumentação de que os encargos/ custos de qualquer aprimoramento profissional deveriam ser assumidos pelo próprio trabalhador, em razão do retorno pessoal que lhe proporciona. Sob esse ponto de vista, não é apenas a prefeitura e a área da saúde que se beneficiam, mas o funcionário também colhe resultados de seu investimento, por meio da melhoria de seu currículo, ampliando sua empregabilidade. Uma vez que esse acréscimo curricular não foi procurado, mas oferecido como capacitação para o trabalho para a execução de política pública, esse tipo de argumentação desmancha-se no ar.

Salienta-se aqui que os entrevistados que verbalizaram a "falta de incentivos" incluíram as insatisfações difusas do trabalho e da falta de reconhecimento que esperavam das prefeituras por sua disponibilidade em melhorar seu desempenho profissional. Mas a concretude das relações sociais desiguais faz sentir-se nas reclamações concentradas dos trabalhadores de menor poder aquisitivo de que ao trabalhador mais desprovido de recurso exigem-se mais sacrifícios. Ele cede passivamente, ou desiste do curso, como desinteressado, não merecedor de incentivos que, de qualquer forma, não lhe foram concedidos.

As propostas de uma iniciativa nacional para a formação de facilitadores da educação permanente em saúde, com sistematização articulada das experiências de trabalho com as instituições formadoras, não foram também consideradas. As escolhas, portanto, não primaram pelo cuidado na representação equitativa do quadrilátero do SUS, e ainda que tenham sido priorizados os trabalhadores da saúde, foram excluídos os formadores, e houve apenas um representante de usuários incluído nesse processo.

Trata-se, em princípio, de uma prática dissonante da filosofia do SUS, uma vez que o eixo reordenador da política de saúde pública brasileira é a redemocratização do setor, possibilitada pela participação da sociedade no acompanhamento e fiscalização dessa política. Causa estranheza que a escolha dos facilitadores de EPS, como estratégia para a efetivação do SUS na locorregião, tenha sido feita de forma dissonante entre o que é defendido como princípio do sistema "participação da comunidade" (Brasil, 1988, art. 198) e o que continua, tradicionalmente, sendo praticado no País.

A Política de Educação Permanente em Saúde é uma política pública e, ao ter seus atores sociais indicados por meios não suficientemente esclareci- 
dos ou pela própria autoindicação, prejudica os princípios da democracia na saúde. Cabe ressaltar, também, algumas exclusões automáticas de outros atores engajados nas questões do SUS que, teoricamente, poderiam participar do processo, mas como não pertenciam ao círculo de relacionamento pessoal-profissional de quem coordena as ações, ficaram fora da seleção. Essa Política, que deveria diminuir as injustiças sociais ao oferecer equidade de atendimento dentro das unidades de saúde, acaba tendo em sua exegese a parcialidade e a verticalização no próprio processo de escolha dos facilitadores de EPS. Esta influenciou o desenvolvimento das ações na locorregião.

Dando prosseguimento, focou-se a análise dos dados obtidos e percebeuse, durante esse processo, que a grande maioria dos entrevistados consegue fazer uma apreciação mais profunda e crítica sobre a qualidade das ações desenvolvidas na locorregião. É notório que os envolvidos no processo possuíam poucas informações a respeito da Política de Educação Permanente em Saúde, da metodologia da problematização indicada e da própria formação da qual estavam participando, o que resultou em uma dificuldade de implementar o que estava previsto, como foi exemplificado pelos sujeitos.

No final do Curso de Formação, os atores sociais envolvidos foram convidados para uma avaliação coletiva, solicitada pelo Deges/MS e ENSP/ Fiocruz, a qual demonstra a necessidade do envolvimento dos atores do SUS, principalmente dos gestores, e diversas questões apontadas que ressaltam a importância da implementação da Política para a efetivação do SUS. Esta avaliação foi realizada no $2^{\circ}$ Encontro Presencial, conjuntamente pelas turmas da locorregião de Franca e de Araraquara, como apresentado a seguir.

O processo instalado a partir das iniciativas da Política de Educação Permanente em Saúde revela aspectos importantes na implementação do SUS, como a participação da sociedade civil organizada, do município, a existência de cooperação técnica e científica de todas as organizações sociais, com objetivo de produzir conhecimento, pesquisas e desenvolver tecnologias de forma a propiciar maior acesso às informações e análises sobre a área de recursos humanos da saúde no País.

Já se passou uma década desde que Gastão Campos (1997, p.138, destaque do autor), ao analisar a estratégia de viabilização do SUS, alertava para a necessidade de "[...] se criar uma dinâmica e funcionamento do sistema de tal maneira que os denominados 'recursos humanos' sejam um dos principais sujeitos do processo de mudança”. O autor pondera ainda que "[...] não 


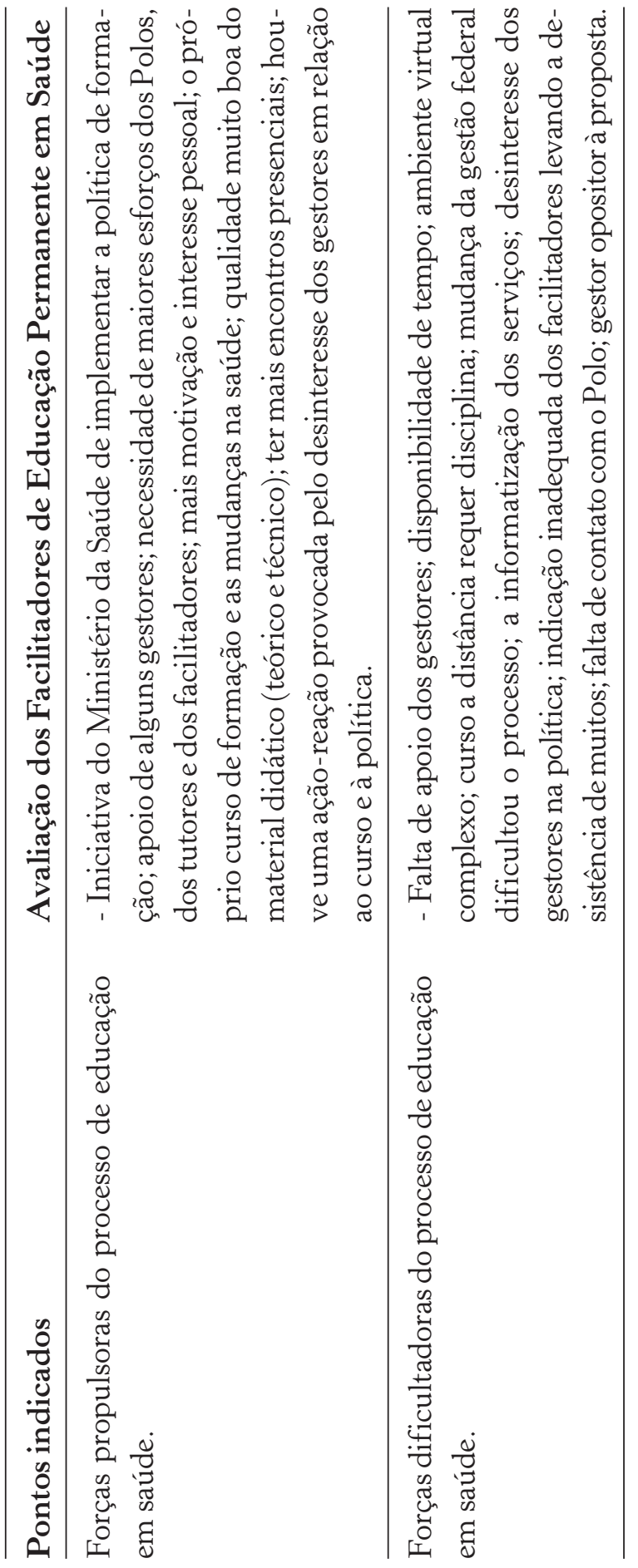




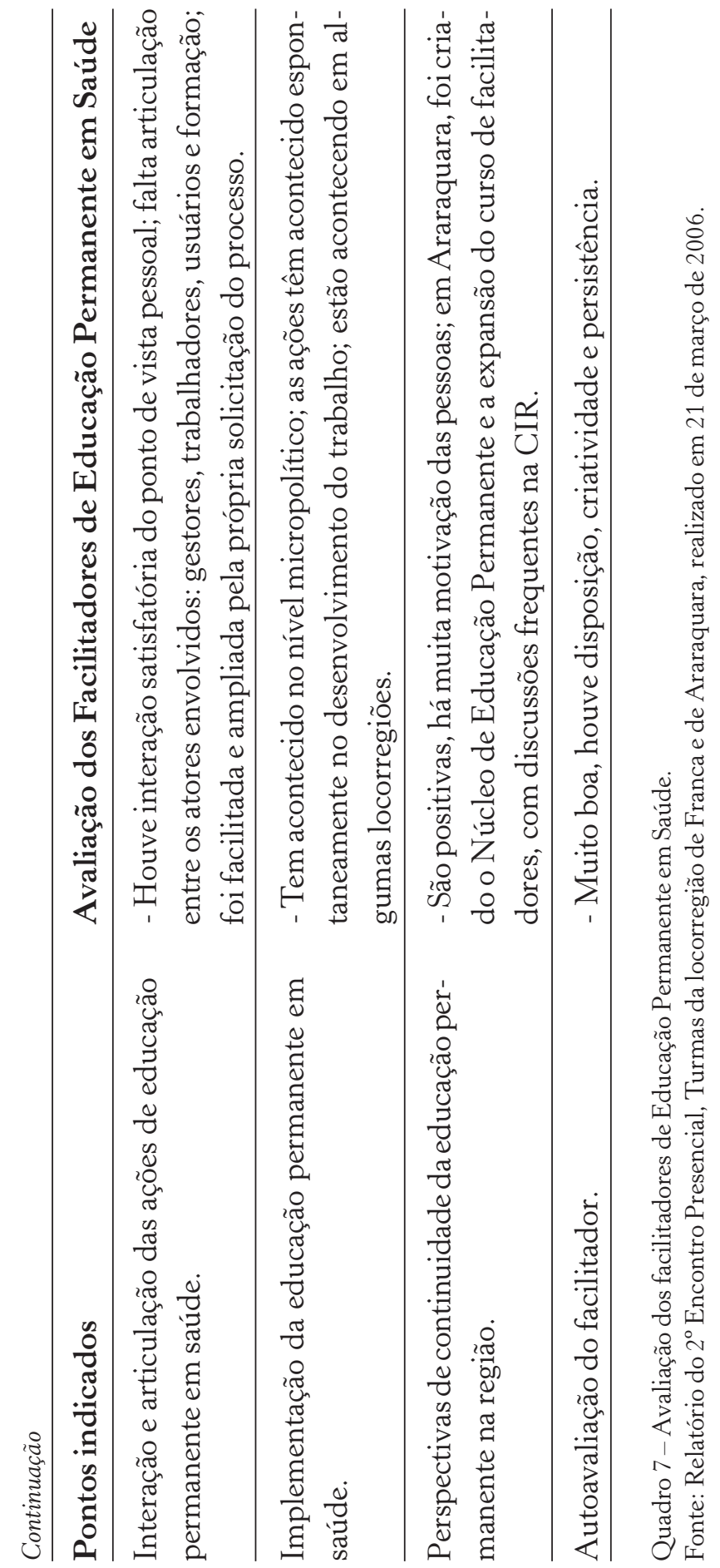


é possível fazer avançar o SUS sem a integração e este esforço da maioria dos trabalhadores de saúde", sinalizando a necessidade de atender às demandas dos médicos sem invalidar as características essenciais do SUS. Lembra que “[...] não haverá reforma sanitária contra os médicos" (Campos, 1997, p.137).

Apesar do peso de tal advertência, muitas vezes inclina-se a pensar que apenas os profissionais administrativos da saúde, uma vez capacitados, conseguiriam "virar a mesa". Essa postura ingênua levou a perceber que a formação dirigida à preparação técnica de funcionários poderia ser entendida como provocadora de uma reforma transformadora da área, embora na prática, restrinja-se a mudanças possíveis na linha da modernização consentida e absolutamente inerte.

Essa fala demonstra a insatisfação do trabalhador da saúde com o modo de encaminhamento do processo, quando critica a postura centralizadora e autoritária da equipe da DRS VIII, ou seja,

têm uma postura assim mesmo, só elas sabem. Por que não conseguiu construir o diálogo? Porque era uma das coisas básicas. [...] E frustra, não frustra? Então é, também assim, tudo interrogado. Será que é esse o caminho? Por que a gente é sempre o último a saber? Por que, né? Então, talvez tá interrompendo porque não tem interesse mesmo. (S4)

Referindo-se às forças da sociedade para uma mobilização reformista de implementação definitiva do SUS, cabe refletir sobre a adesão de todos os seus atores como protagonistas. Dentre esses, o mais vulnerável, e que tem sido constantemente vitimizado como objeto de um atendimento precário em suas doenças, tem sido o usuário. O bombardeio constante da mídia em geral consolida a opinião pública de que só se sujeitam ao atendimento do SUS aqueles que, em decorrência da pobreza e fracasso social, não conseguiram dar um passo a mais na escada social, destinada aos mais hábeis e preparados.

Não se trata apenas do desconhecimento da proposta do Sistema Único de Saúde, mas principalmente de uma profunda e arraigada descrença no inespecífico setor público, infelizmente confirmado quase diariamente pelos fatos. A ideia social desse sistema de saúde, por partir do pressuposto da universalidade de acesso e da atenção integral da saúde pública como direito, surge como conflitante ao modo de viver e de produção predominante hoje na sociedade capitalista: desigual, individualista e excludente. 
Minayo (2004), ao esclarecer a distinção entre os conceitos saúde pública e saúde coletiva, informa que o primeiro consagra uma dimensão reducionista de direção e de intervenção do Estado em uma área social mais ampla e complexa do que a definida pelas práticas sanitárias oficiais; já o segundo conceito é ambíguo e inespecífico. O adjetivo "coletivo" comporta uma ampla conotação de exterioridade que se estabelece frente ao objeto, incluindo conquistas sociais profundas para a maioria da população e chamando a atenção para a forma dominada e marginal com que se definem as políticas sociais. Portanto, segundo a autora, “[...] saúde coletiva é um tema da prática política da classe trabalhadora [...], pelas prioridades sociais que se colocam sempre em relação de negatividade com os interesses econômicos" (Minayo, 2004, p.192, grifo no original).

A busca de encaminhamentos positivos para os problemas que impedem a qualidade do atendimento aos usuários do SUS, bem como o acolhimento, a melhor compreensão do processo saúde/doença e a satisfação dos trabalhadores, estão pautados na ideia de que a realidade está aí para ser construída e transformada em um constante compromisso com a vida humana. A definição de objetivos comuns e de propostas construtivas pode resultar em transformações, conquistas, vínculos e relações. Estas visam contribuir para a formação profissional que considere os determinantes sociais no processo saúde-doença e a atenção ao usuário na integralidade e na condição de sujeito social atuante, e não como mero objeto da ação e intervenção do saber reconhecido oficialmente. "Transferem a ênfase dos corpos biológicos para os corpos sociais, entendidos como grupos, classes e relações sociais" (Teixeira, 1989, p.79).

Considera-se, na perspectiva analisada, que a investigação nessa área engloba uma instância coletiva de reflexão e representa, no campo do conhecimento, aquisição de saber que pode melhorar a saúde das pessoas, uma vez que no paradigma ora preconizado, a indagação constante à realidade organiza e orienta critérios para essa demanda da sociedade. É nesse sentido que a formação comprometida com o conhecimento técnico-científico e as políticas educativas baseadas no diagnóstico locorregional apontam a formação de profissionais comprometidos e capacitados a atuarem como sujeitos, agentes das necessárias mudanças de mentalidade, de ação e resultados concretos para a população. 


\section{A contribuição da Educação Permanente em Saúde}

Esta formação trouxe sem dúvida muita contribuição, porque leva à reflexão, a ter uma visão mais ampla sobre a realidade, sobre as questões sociais, sobre as necessidades da população. Então, favoreceu porque possibilitou ter um olhar diferente na abordagem com o usuário. [...] Na unidade onde trabalho, eu acredito que também contribuiu com relação às posturas, à maneira das pessoas também estarem entendendo o serviço que desenvolvemos. Esse relacionamento eu acredito que melhorou. [...] Sempre que há oportunidade, estamos conversando. [...] Na unidade, nós tivemos duas reuniões num período de um ano, então é pouco, é insuficiente. [...] É conforme a necessidade. (S1)

Eu acho que teve muito significado. Muito, eu aprendi muita coisa, eu achei o material muito bacana. Eu já utilizei aquelas apostilas do curso em vários trabalhos e projetos. Eu achei que o curso, o presencial, tiveram pessoas, discussões muito legais, conheci muita gente bacana que estava engajada em processos muito melhores, coisas maiores. E aí... Depois, [...] uma falha foi... Acho que eles não estavam preparados com a estrutura, pra fazer a Formação a Distância. Acho que a falha na internet teve, não muito, mas teve. Eu acho que [...], às vezes, o Ministério lança uma proposta que é linda, mas ele não tem o suporte. Eles precisam planejar, a parte de planejamento tinha que ser maior [...], eles lançam uma coisa e não dão continuidade, para no meio do caminho, se perde. $\mathrm{O}$ presidente muda, muda a equipe, muda tudo. Eu acho que essas coisas, de planejar [...], elas têm que ser melhores, para ter estrutura pra oferecer pro trabalhador que realmente começa e não desanimar, né? [...] Você não tem que mandar de cima pra baixo, mas tem que ser numa roda, em comum. [...] Porque é uma ideia que ficou marcada, então eu nunca vou esquecer esse conceito da roda, porque, pelo filme eu vi que é algo muito importante que precisa ser trabalhado. Por que você tá fazendo isso? Porque alguém mandou. (S 2)

Teve demais, lógico que sim. Porque tudo que a gente vê, aprende de novo é uma coisa a mais. [...] Eu gostei de tudo. Pra começar, do curso que a gente fez em Serra Negra. Os quatro dias que a gente ficou, a gente teve, ouviu muita coisa boa, teve muito contato com pessoas diferentes, diversos lugares, trocas de ideias, foi muito bom. [...]. A gente conseguiu transmitir pra alguns, e passar uma coisa melhor pro usuário, né? [...] É como eu te falei: melhorou na maneira de atendimento, de atender o usuário, entendeu? [...] Eu sempre procurei, desde que eu entrei aqui, a tratar todos muito bem, atender bem, mas a gente parece que aprendeu, assim, a se colocar mais no lugar dos usuários, pra saber assim o que realmente eles sentem, né? Entender as necessidades dos usuá- 
rios [...] O curso ajudou a ter mais facilidade de aproximar, de chegar até nós. Eu senti isso. (S3)

Essa formação? Ampliou a minha visão também. Lembra que eu te falei que a gente vai aprendendo a ampliar? Isso aí ajudou bastante nessa questão. [...] A chamar o funcionário, a ter mais atenção com o usuário, não olhar ele como só vindo aqui pra usar o serviço, mas, às vezes, ele vem e ele quer só uma atenção. Então, nessa parte, assim, de envolvimento com o funcionário, de estar conversando, pedindo pra ele dar mais atenção e levar ele pro caminho certo. [...] Então, direto eu falo com o pessoal dar um pouco mais de atenção, levar o usuário aonde ele realmente quer, onde faz, e ir junto com ele. Ele quer atenção. A educação permanente me ajudou a ampliar minha visão, humanizar um pouco o atendimento. Porque, às vezes, se torna mecânico, você mecaniza o seu trabalho, você, às vezes, não para pra ouvir o usuário. [...] Vai acostumando, a rotina. E o curso mudou um pouco isso aí. Por isso que eu acho que a educação permanente não deveria parar, porque você vai aprendendo coisas novas, vai vendo coisas que, às vezes, não é tão novo, mas que você precisa resgatar. Do seu trabalho, da sua vida pessoal. (S4)

As possibilidades de aprendizado e a revisão de procedimentos vão ao encontro das necessidades sentidas pelos trabalhadores da saúde e as dificuldades próprias do sistema público de saúde, ou seja, a importância da educação permanente em saúde para o desenvolvimento do trabalho no Sistema Único de Saúde, para troca de experiências, valorização profissional, busca de soluções coletivas, entre outros aspectos, estão apontados nos depoimentos.

Observa-se nas falas dos sujeitos que a formação possibilitou aproximar a educação do processo de trabalho e levou à reflexão do cotidiano, ampliando a visão da realidade. Assim, a educação permanente leva a conhecer as questões sociais e as necessidades de saúde da população e aproximar os trabalhadores dos usuários com um olhar mais integral. Ajuda, do mesmo modo, a melhorar o relacionamento entre os próprios trabalhadores, mesmo em pequenas ações, como a de conversar sobre as atividades do dia a dia, a realizar planejamento conjunto e, principalmente, a conquistar espaço nas unidades para refletir o trabalho. Pode-se dizer que a educação permanente ajuda na humanização do atendimento em saúde.

Ao analisar a contribuição e o significado da formação em educação permanente em saúde, com a introdução de procedimentos para a qualificação 
da atenção na rede, organização dos serviços, dos processos formativos e das práticas pedagógicas, identificou-se entusiasmo nas falas dos trabalhadores. Há, portanto, uma grande satisfação dos trabalhadores com as oportunidades e possibilidades de trocarem experiências e conhecimentos para melhorar a qualidade do atendimento oferecido nos serviços de saúde.

A Política de Educação Permanente acrescentou aspectos considerados importantes pelos sujeitos entrevistados: "[...] acho que foi um marco, pra falar assim, vamos parar de gastar dinheiro à toa e vamos, realmente, fazer uma aprendizagem que tenha sentido, que tenha a proposta do que a gente está querendo fazer. Parar de treinar pessoas, mas fazer as pessoas pensarem realmente" (S2).

É preciso lembrar que a compreensão predominante do processo de educação no contexto brasileiro expressa, muitas vezes, as ideias e práticas de mercado que não representam uma agenda estratégica capaz de refletir as demandas sociais e representações da complexa estrutura da sociedade. Tornam-se incapazes de ir além dos problemas aparentes e particulares e transcender para o coletivo, no reconhecimento da desigual concentração de renda, do processo de trabalho, da falta de planejamento urbano, de oportunidades educacionais, ao acesso à saúde, à água potável e à moradia de qualidade. São esses os eixos estruturantes e norteadores do processo de educação em saúde que, dentre outros, conformam o quadro que constitui a realidade social.

Nas entrevistas, verificou-se que nem todos os facilitadores conseguiram efetivar no trabalho as ações de EPS propostas, porque o compromisso pactuado para a implementação da política não foi assumido. A construção da roda no SUS assinalou uma possibilidade para aprender a pensar no coletivo, de quebrar a rotina e evitar que o trabalho fique mecanizado, mas as ações foram pontuais e desarticuladas. É certo que a formação vivenciada pelos facilitadores de EPS ampliou a visão de mundo e a crítica do (não) funcionamento institucional.

Ao indagar a realidade, verifica-se que, embora as possibilidades estejam dadas, elas não são automaticamente compreendidas nem resultam instantaneamente em alternativas e em compromisso profissional de trabalho fundamentado na qualidade e referente aos interesses coletivos dos usuários. A construção do aprendizado em saúde é complexa e revela a superação de práticas individuais e tradicionais que, ao longo dos tempos, em nosso 
país, reforçaram muito mais a erradicação das doenças do que as condições de saúde.

Compor e recompor o processo de integridade torna necessária a reorganização do trabalho que envolve tanto o gestor e o trabalhador da saúde como o usuário. Conforme recomendam Bravo \& Matos (2004) ao analisarem essa ação, ela deve ser realizada em sintonia com o movimento dos trabalhadores e usuários que lutam pela real efetivação do SUS; e facilitação do acesso aos serviços de saúde; garantia da participação popular e dos trabalhadores nas decisões a serem tomadas. Os autores lembram aos trabalhadores a necessidade de qualificação, sistematização do trabalho desenvolvido e realização de uma postura investigativa constante sobre temáticas relacionadas à saúde.

Vasconcelos (2002, p.429) ressalta que o trabalho voltado para o coletivo contribui para a politização das relações sociais, tornando essencial, entre outras medidas, "[...] não só o investimento na capacitação dos profissionais, mas também o resgate na reconstrução da relação entre poder público e sociedade civil". Começa pela descrição do cenário onde se dá a ação, mapeando o espaço e as demandas de saúde, levando ao conhecimento dos dados epidemiológicos, as informações sobre os aspectos culturais da sociedade ali instalada, "[...] publicizando a conexão/desconexão entre as demandas para a saúde, os programas governamentais e os recursos realmente existentes".

Para tanto, a formação deve proceder de indicação dos Polos, a partir da discussão ampliada dos problemas que vêm impedindo a construção do cuidado integral em saúde, com o objetivo de ampliar a massa crítica capaz de atuar e desenvolver no sistema local locorregional. Mediante tal articulação, é possível identificar e priorizar os problemas, as atividades cotidianas desenvolvidas nos serviços, os temas a serem trabalhados nas iniciativas de educação permanente. Aponta, portanto, em direção à dinamização da descentralização das deliberações e à participação dos municípios, para que não fiquem mais isolados do poder decisório e possam implementar as estratégias previstas.

Nessa abrangência, para Vasconcelos (2002), a formação de recursos humanos em saúde é um dos mais sérios problemas a ser enfrentado. A dificuldade que atualmente pode ser observada na defesa da saúde pública e, consequentemente, do SUS pelos profissionais da saúde e população usuária, é a persistência do modelo clínico - novo modelo assistencial. Na sequência, a autora esclarece seu ponto de vista com a afirmação de que, notadamente, os 
profissionais médicos muitas vezes chegam a desconhecer a própria "[...] dinâmica institucional e o conjunto das reais demandas que os segmentos populares trazem para o interior das unidades de saúde" (Vasconcelos, 2002, p.436).

Um dos aspectos preocupantes nesse desenho é a formação profissional fragmentada e distante do perfil adequado para o trabalho na área da saúde pública. A busca integrada, integradora e sistemática pelo desvendamento das necessidades de saúde da população de uma região é indispensável para que, afinal, os processos de trabalho possam ser efetivamente processos educativos. Ao analisar o papel que a educação em saúde deve ocupar na construção de sujeitos de direitos portadores de qualidade de vida, trabalho e estilo de vida, somos esclarecidos de que é nos programas de saúde

que estão postas, com menos limites, as possibilidades de uma prática em saúde que, articulando os interesses sociais e os interesses individuais na saúde, firmem os princípios fundamentais norteadores da saúde como direito social, através de práticas pedagógicas, mediadoras desses conteúdos e mediadas por aqueles princípios, consolidando a conexão entre unidades de saúde/profissionais de saúde com a comunidade e com os grupos organizados da sociedade (Vasconcelos, 2002, p.439).

Essa afirmação vem assinalar a importância do reconhecimento da EPS na atualidade para a mudança de paradigma de (re)organização dos programas de saúde, dos serviços e das práticas desenvolvidas. A proposta tem fundamentação no processo de implementação do SUS enquanto direito social e política pública, construindo espaços democráticos na busca de respostas e soluções para melhorar a qualidade de saúde.

O pressuposto básico é a desconstrução das ações dicotomizadas nas práticas individuais para avançar na edificação permanente do processo de "aprender a aprender" ou "aprender a construir saúde", que, de antemão, exige o exercício do trabalho em equipe voltado ao processo educativo que valorize o conhecimento tido como "não científico" e aquele reconhecido como científico; e que seja estruturado sob o conceito ampliado de saúde, no qual as várias disciplinas alternam papéis na construção da atenção integral à saúde e sua promoção.

É nesse sentido que as práticas de educação saem das agendas acadêmicas para se integrarem às práticas dos serviços públicos de saúde. O proces- 
so de "aprender a construir saúde" implica a formação permanente dos trabalhadores da saúde, a perspectiva da aprendizagem significativa como possibilidade para a construção de sujeitos ativos na reflexão crítica sobre os processos de trabalho no SUS (Bertani et al., 2008).

Nota-se que a qualidade do material de suporte utilizado no Curso de Formação de Facilitadores de EPS foi reconhecida pelos sujeitos, assim como os recursos audiovisuais e os filmes, os quais servem de referência para o trabalho das unidades de saúde, certamente por responderem às necessidades vivenciadas. Relaciona-se esse aspecto à postura político-pedagógica adotada e ao uso da metodologia da problematização indicada, que estimula, entre outras coisas, a aprendizagem significativa.

Agora, mudou muito na minha questão profissional, porque, além de ser um conceito novo, eu utilizei o material várias vezes no trabalho. As dinâmicas, os filmes. [...], eu utilizei o filme do Dorival na Oficina Macro Regional de Educação Permanente, que é um filme bacana pra discussão das coisas que são mandadas de cima pra baixo e que a gente quer quebrar com a educação permanente. (S2)

Dessa perspectiva, o desenvolvimento da consciência crítica processa-se por intermédio de procedimentos pedagógicos que tomam como referência de aprendizado a experiência de vida do sujeito para a transformação da realidade, um gesto de libertação de uma situação de ignorância/opressão, como ensina Freire (2001). A educação que intenciona o conhecimento crítico tem de levar em conta as experiências vividas pelos sujeitos, senão não há aprendizado e nem reflexão crítica, já que o ato de conhecimento nasce da relação entre o conteúdo e o cotidiano, uma vez que estimula a pensar na própria vida.

A reflexão sobre o trabalho no SUS exige uma "caixa de ferramentas" que, para Bertussi (2004), inclui a aprendizagem significativa, a produção do cuidado, o trabalho em equipe, a definição de prioridades, a paciência e o respeito à diversidade, dinamizando coletivos para produzir integralidade da atenção, humanização do cuidado, reconhecimento da autonomia e direitos dos usuários dos serviços de saúde. A EPS, ao sinalizar o processo de aprendizagem significativa, possibilita caminhos alternativos para que os saberes existentes contribuam para a apropriação do SUS, permitindo a re- 
flexão do mundo do trabalho e dos problemas que impedem o atendimento de qualidade. Esses problemas são objeto da EPS, traduzindo as necessidades e as diferenças de cada local por meio das rodas, funcionando como dispositivo integrador e inclusivo no SUS.

Essas questões demonstram a importância de ampliar a formação e qualificação dos trabalhadores da saúde na dimensão técnica, ética e política, e nas inter-relações pessoais, para que participem como sujeitos integrais do mundo do trabalho. A área da saúde tem, assim, o desafio de desenvolver um processo que permita identificar e promover os saberes e os conhecimentos dos trabalhadores, para melhorar a qualidade da assistência e do próprio atendimento, incorporando em suas ações os princípios e valores que orientam o SUS (Sarreta; Eto, 2007). É um caminho que pode oferecer pressupostos para orientar a formação profissional na saúde, tanto na perspectiva do mundo do trabalho quanto na perspectiva educacional.

As mudanças sofridas nas últimas décadas, no contexto político, econômico, social e cultural, revelam a fragmentação do trabalho, da produção, das relações sociais e da própria formação profissional. Revelam também as fragilidades do modo de organização da sociedade em busca de seus direitos sociais, entre os quais se encontra a educação. A configuração atual do capitalismo caracteriza-se, sobretudo, pela fragmentação de todas as esferas da vida social.

A consequência desse processo é o aprofundamento das desigualdades econômicas e sociais, refletidas na exclusão social, nas diferenças, no empobrecimento da população e, principalmente, na perda ou ameaça dos direitos sociais. É um modelo de desenvolvimento pautado apenas na ótica econômica, sem preocupação com o indivíduo ou com a comunidade e a sociedade. Essas transformações estruturais, que configuram a globalização econômica, acontecem na mesma proporção que a globalização da exclusão social, ideia defendida por Dowbor (1998) relacionada a essa realidade em que se torna cada vez mais difícil identificar o bem-estar humano com o bem-estar da economia.

Interessante nesta análise é a discussão de Chauí (2003) sobre a concepção de educação permanente apresentada na atualidade, inclusive pela universidade, quando afirma que diante de tantas transformações postas pela globalização e pelo mercado de trabalho competitivo e massificado, e, principalmente, pelas exigências do capital de mão de obra rápida e reciclada, a 
educação permanente é uma estratégia pedagógica necessária. Entretanto, para a autora (Chauí, 2003, p.11) "[...] significa que a educação não se confunde com os anos escolares; isto é, a educação deixa de ser preparação para a vida e torna-se educação durante toda a vida". Por isso, atividades de treinamento e reciclagem, incentivadas para atender às finalidades das empresas e também das instituições, não podem ser confundidas com educação permanente,

porque a educação significa um movimento de transformação interna daquele que passa de um suposto saber (ou da ignorância) ao saber propriamente dito (ou à compreensão de si, dos outros, da realidade, da cultura acumulada e da cultura no seu presente ou se fazendo). A educação é inseparável da formação e é por isso que ela só pode ser permanente (Chauí, 2003, p.11).

Dentre algumas mudanças que Chauí (2003) apresenta para a universidade pública, em uma nova perspectiva de modernização, de uma nova universidade para um mundo em transformação, uma delas exige uma ação crítica dessa instituição social contra a exclusão social, a democratização do conhecimento e que, orientada pela ideia de cidadania, assegure sua autonomia e redefina sua atuação social e política.

Para isso, é preciso exigir que o Estado "[...] não tome a educação pelo prisma do gasto público, e sim como investimento social e político, o que só é possível se a educação for considerada um direito, e não um privilégio, nem um serviço" (Chauí, 2003, p.12). Romper, portanto, com a lógica da reprodução do capital, definida pelo neoliberalismo e pela globalização, que orienta a desconstrução dos direitos sociais e das políticas públicas em um referencial de mínimo social, é adotar a perspectiva de uma formação voltada para a emancipação dos indivíduos e da sociedade.

A EPS, inserida no processo global de formação do sujeito que trabalha na saúde, estimula o pensamento, as dúvidas, as incertezas, para que isso leve ao exercício da interrogação, da reflexão e da crítica, como ensina Chauí (2003, p.13), porque “[...] há formação quando há obra de pensamento e que há obra de pensamento quando o presente é apreendido [...], de tal maneira que nos tornamos capazes de elevar ao plano do conceito o que foi experimentado como questão, pergunta, problema, dificuldade".

Enfim, o enfrentamento dos desafios no processo saúde-doença implica a organização e o compromisso de toda a sociedade, para que a saúde e a 
educação possam ser vistas como condição essencial para o desenvolvimento do sujeito e do país. Implica também, do mesmo modo, uma formação em saúde baseada na interdisciplinaridade, evitando a fragmentação e a profissionalização, que enfoca a técnica, a individualização, e que "[...] leva à formação de sujeitos culturalmente empobrecidos" (Dominguez, 2006, p.32).

Ao estimular o pensamento crítico acerca das dificuldades e limites vivenciados na saúde pública, seja no universo de trabalho, da formação, seja no da pesquisa, a EPS estimula o compromisso com a reformulação dessa política pública de Estado que é o SUS.

Esse processo imaginado, de construção da roda ampliada, comporta todos os diferentes atores da saúde. Assim, a gestão colegiada resultante verifica-se no compromisso com as transformações sociais, tão necessárias, e no reconhecimento do potencial de mobilização, para romper com as estruturas tradicionais dentro da saúde pública. A proposta de corresponsabilidade possibilita desenvolver a autonomia dos atores sociais e a construção de novos conhecimentos para legitimar e atender às demandas do SUS.

O processo de constituição de uma gestão colegiada da EPS proposta pelo gestor federal "[...] quebra a regra da verticalidade única e hierarquizada nos fluxos organizativos. Também supera a racionalidade gerencial hegemônica e a tradicional concepção educativa dos treinamentos para pessoal de serviço" (Ceccim \& Feuerwerker, 2004, p.51). Os autores complementam que a roda representa não apenas "[...] um mecanismo mais democrático e participativo de gestão, é um dispositivo de criação local de possibilidades (neste tempo e lugar)" (Ceccim \& Feuerwerker, 2004, p.52).

A gestão colegiada da EPS, para Gastão Campos (2000), pode trazer novos arranjos e composições nas estruturas organizativas do SUS comprometidas com o projeto ético e político da Reforma Sanitária brasileira. O desafio da roda é conseguir estabelecer uma concepção que supere a estrutura verticalizada, para criar possibilidades e alternativas de trocas. Dessa perspectiva, a implementação dos Polos é uma construção permanente para a implementação do SUS, em que todos estão aprendendo coletivamente a exercitar o diálogo, a articulação e a constituição de novos sujeitos. O (re) conhecimento das necessidades de saúde da população da região é indispensável para pensar nos processos de trabalho, e ao partir da realidade e do saber das pessoas, exercitar a prática educativa em processos de trabalho educativos. 
A abrangência desses subsídios é significante na consolidação da Reforma Sanitária brasileira, e ao mesmo tempo fornece elementos para melhorar a estruturação dos projetos desenvolvidos na rede de saúde pública, contribuindo também para nortear uma ação de transformações no atendimento: mais inclusivo, social e integral.

Pode-se afirmar que a operacionalização da Política de EPS encontrou na criação dos Polos uma possibilidade de reunir aspectos preconizados pelas próprias diretrizes da Reforma Sanitária: a participação de diversos atores, incluindo os representantes da comunidade, possibilitando o embrião do controle social, que parece não se dar por outros meios mais espontâneos. Outro aspecto a ser ressaltado é a indução expressa na política de eliminar a fragmentação com que se vêm dando as ações de atenção direta em saúde e o caminho que aponta para a solução coletiva desse problema por meio da formação e qualificação de todos os atores do SUS. Desse modo, é uma política transversal, que atravessa todas as instâncias do SUS e apresenta elementos emancipatórios e valores que sustentam a autonomia e podem contribuir para ampliar o conceito do SUS e sua defesa.

A proposta dessa Política de EPS é desenvolver um processo de formação dos atores da saúde que reformule os conteúdos com temas teóricos e práticos relacionados com a promoção da saúde e atenção integral, o controle social e o caráter multiprofissional e interdisciplinar das práticas da saúde. Mas também uma formação que inclua conteúdos disciplinares sobre a diversidade da população brasileira, os aspectos da subjetividade relacionados com a assistência em saúde, os processos educativos, a qualidade da atenção, direitos e deveres de cidadania, organização e funcionamento do SUS. Enfim, uma formação que esteja vinculada ao movimento de transformação da sociedade e desenvolva condições para o exercício democrático e participativo no SUS, legitimado pela luta da sociedade brasileira, para que os atores sociais atuem como sujeitos de transformação para a construção de uma nova saúde, fortalecendo na locorregião o atendimento às necessidades de saúde da população e aos interesses coletivos.

Interessante é notar a expressividade do uso da metodologia indicada, que ressurge na fala dos sujeitos destacando como positivo o uso da problematização no processo de ensino/aprendizagem no trabalho. $\mathrm{O}$ aspecto relevante dessa constatação é que os sujeitos evidenciavam entender o processo e nele envidaram esforços. 
A metodologia da problematização, a gente consegue desenvolver justamente por estar em contato com as pessoas, com os profissionais, com estas questões. Então, não tem como você não estar questionando. E você reflete em conjunto, é interessante, tem opiniões divergentes, isso tudo enriquece a sua própria formação, e isso contribui pra gente estar fazendo um trabalho voltado pra essa transformação. [...] Essas experiências são muito amplas. Quando você está no seu trabalho com o usuário, você tem esse espaço, que pode ser usado como educativo, como troca de saberes. Então, isso já é um incentivo, é uma coisa importante, isso por si só já dá um impulso. [...] A gente tem muita dificuldade, mas não somos só nós, percebemos que não é de uma pessoa, de um membro do Conselho; é também a população que tem essa dificuldade de participar. [...] Tanto os profissionais, de estar lidando com essas questões de saúde, de estar ouvindo o usuário, de propor mudanças nas políticas, favorecendo o usuário, quanto da população em si de lutar por seus interesses. (S1)

Eu acho que isso é um processo que tá ganhando força. [...] Consigo construir a roda. A gente senta a equipe toda, do médico à faxineira, pra discutir as propostas do PSF. Então, isso foi um ganho que eu consegui, [...] porque eles sentem falta desta discussão em roda. O gestor fecha a unidade do PSF, uma vez ao mês, durante o dia todo, e isso já tem dois anos [...], até hoje a gente está conseguindo. [...] Então a própria equipe do PSF fez um trabalho com a população pra que aquele dia [...], ela sabe que a unidade é fechada pra que os profissionais possam sentar e conversar e discutir. E a população aceita isso, a população acha que isso é bacana porque vai oferecer um serviço de qualidade. Então foi feito todo um trabalho com essa população pra ela aceitar isso também. [...] Agora a gente fez o projeto "Entrando na Roda", que é do PSF. [...] E agora a gente tem o "Projeto Integração", que está acontecendo na Secretaria, que é uma reunião, uma vez por mês com todos os gerentes de unidade [...]. A gente se reúne, cada chefe de unidade traz a tua proposta, o teu problema, a tua dificuldade pra gente discutir as soluções. [...] Então a gente vai levantando as questões, troca de ideias, [...] dá sugestão, vai problematizando. [...] A gente senta para levantar os problemas e para buscar as soluções juntas. As que são possíveis, não é? Tem soluções que a gente realmente fala: "Não, isso depende muito do prefeito, do gestor e tal”. O secretário de Saúde participa. Só que muitas vezes a gente consegue resolver com a equipe. (S2)

Do ponto de vista dos trabalhadores da saúde, a consciência de ampliar essa nova dimensão do trabalho na formação em saúde requer melhor compreensão do processo de trabalho e maior articulação entre os diversos conhecimentos existentes da saúde. Por um lado, a atenção à saúde, e não ape- 
nas a assistência médica, incorpora novos processos de trabalho, solicitando efetivo compromisso dos trabalhadores com a concepção ampliada de saúde. Por outro lado, a integralidade da atenção, reconhecida como um princípio que contempla as dimensões biológicas, psicológicas e sociais do processo saúde-doença, passa a ser difundida como uma nova cultura da saúde na formação profissional. O paradigma político-assistencial torna-se também político-pedagógico, orientando as propostas para a formação emancipatória na saúde.

De qualquer maneira, o desenvolvimento dessa estratégia, supostamente, deve-se a partir das experiências e criatividade dos profissionais, como expediente pessoal para responder à proposta de aprendizagem indicada pela Política, demonstrando a importância de construir ações de formação conjuntas para a troca de saberes e de experiências.

O levantamento sobre as formas de participação na Política de Educação Permanente em Saúde na locorregião de Franca, a partir da visão dos sujeitos entrevistados e da observação da pesquisadora durante o processo, mostrou pontos de vista diferentes dos atores sociais de uma mesma temática. Esse fato encontra-se no centro das preocupações, uma vez que o método se constrói por intermédio das pessoas envolvidas, ao quebrar os tradicionais esquemas formais de ensino/aprendizagem.

Assim, foi possível identificar alguns aspectos, altamente positivos, que se complementam: os sujeitos valorizaram a iniciativa de realizar a formação profissional como ampliação do instrumental de trabalho, a necessidade de conhecimentos, a procura pelo novo, por novas experiências, e assim melhorar seu próprio desempenho profissional. No decorrer da análise das falas dos entrevistados, observou-se que alguns entendiam a questão da participação como vivência integrada e integradora.

Pontua-se, aqui, que a integração indagada é a relacionada à possibilidade de expressão do conhecimento vivido e acumulado por cada um, bem como a possibilidade de partilhá-lo durante o processo, como reflete o trabalhador da saúde quando questionado como a educação permanente pode ser potencializada.

Quando você chama a população, chama o usuário, chama o trabalhador pra participar dessas rodas de discussão...Nessas rodas, somos esclarecidos, a gente tem complementações, e é uma motivação pras pessoas estarem conversando as 
questões de saúde. Outra maneira é articulando, convergindo grupos afins, promovendo encontros, participando de fóruns de discussões, mobilizando os sujeitos. Então têm muitas formas e têm outras mais que a gente tem que criar, que descobrir, tem que inventar. Trata-se de um processo, então, todas as ideias são bem-vindas. [...] Não depende de uma pessoa só, tem que ter governabilidade, eu penso que falta essa governabilidade. Mas a gente não pode desistir, é uma luta e tem que estar engajado, e tem que seguir em frente. (S1)

Pode ser potencializada. Eu acho que oferece para os trabalhadores mais oportunidades. Eu acho que valoriza o trabalho. Valoriza as ações. [...] Achar soluções criativas para os problemas comuns, e que todo mundo tem nas unidades. E aí umas das sugestões, [...] de repente é organizar pequenos encontros regionais, pra que as pessoas divulguem as soluções criativas para os problemas. (S2)

A questão da integração dos facilitadores de EPS aproxima-se do processo da aprendizagem significativa. Nesta, o pressuposto fundamental é a interação e se alicerça no processo de ensino-aprendizagem a partir da bagagem de conhecimento prévio trazido pelos envolvidos. $\mathrm{O}$ "novo conhecimento", ou o conteúdo a ser ensinado, deve, prioritariamente, ser construído em permanente interação com aquilo que já se conhece, como conclui Moreira (2007): “[...] em última análise, só podemos aprender a partir daquilo que já conhecemos”.

Nessa proposta pedagógica, o sujeito deixa de ser um receptor passivo encontrado no modelo tradicional de educação, como já demonstrado ao analisar a pedagogia freiriana. A aprendizagem significativa é progressiva e acontece a partir dos conhecimentos prévios, das experiências vividas, dos significados, dos questionamentos da cultura de conteúdo ensinado, entre outros. Assim, quando as condições para essa interação não são proporcionadas, corre-se o risco de manter a aprendizagem mecânica, ${ }^{6}$ a educação bancária, desprovida de significado.

A necessária promoção da aprendizagem significativa não pode ficar dependendo da vontade individual, mas estar atrelada ao conteúdo programático a ser desenvolvido. A falta de vigor no acompanhamento da meto-

6 Educação mecânica é um ensino baseado em respostas transmitidas primeiro do professor para o aluno nas aulas e, depois, do aluno para o professor nas provas. $\mathrm{O}$ mesmo conceito pode ser aplicado para o entendimento da educação bancária. 
dologia da problematização no desenvolvimento da formação em EPS acabou distanciando a possibilidade de interação e participação. Quando os facilitadores de EPS reconheceram a oportunidade da formação para a implementação das ações de educação permanente, perceberam também certa incoerência do Conselho Técnico do Polo da locorregião no afastamento durante o processo.

A metodologia adotada para a construção dos conteúdos também foi sentida como um dos fatores provocadores das desistências, não conseguindo construir espaços para trabalhar esses problemas surgidos durante a formação. Fica claro que a atenção na realização da formação deve levar em consideração não só o incentivo e a dinâmica, mas também que os objetivos do trabalho no Polo do SUS só se realizam se aliados às expectativas e necessidades dos sujeitos envolvidos.

Busca-se, assim, a compreensão desses limites na análise de Ceccim (2005b, p.161): “[...] os serviços de saúde são organizações complexas em que somente a aprendizagem significativa será capaz de adesão dos trabalhadores nos processos de mudanças no cotidiano", e a saúde tem o desafio de reconhecer o "[...] processo educativo incorporado ao cotidiano da produção setorial". O autor analisa que a EPS compreende, então, "a definição pedagógica para o processo educativo que coloca o cotidiano do trabalho - ou da formação - em saúde em análise”, que se torna possível "[...] pelas relações concretas que operam realidades e que possibilita construir espaços coletivos para a reflexão e avaliação de sentido dos atos produzidos no cotidiano".

Outro aspecto relaciona-se à difusão da educação permanente pela Organização Pan-Americana de Saúde (Opas) e pela Organização Mundial de Saúde $(\mathrm{OMS})^{7}$ como estratégia de formação para alcançar o desenvolvimento dos sistemas de saúde, quando assinalam a importância dos trabalhadores da saúde em adquirir novas habilidades e conhecimentos para uma aprendizagem associada às dinâmicas do local de trabalho, uma vez que "existe uma crescente aceitação de que os programas de formação não podem ensinar tudo o que as pessoas precisam saber", conforme análise da OMS (2007, p.47).

Essas organizações enfatizam que os processos educacionais apontam em direção ao aprendizado baseado em problemas, “[...] com maior ênfase no

7 Relatório mundial de saúde, 2006. Trabalhando juntos pela saúde (OMS, 2007). 
'saber como' do que no 'saber tudo"' (OMS, 2007, p.47). O método de aprendizado baseado em problemas ou aprendizado baseado na prática, como ressalta a OMS (2007, p.48), “[...] promove a competência ensinando os estudantes como integrar e aplicar conhecimentos em cenários de prática, aprender com modelos de comportamento e experimentar abordagens interdisciplinares e em equipe à prestação de serviços de saúde".

Nesse sentido, o ensino baseado na prática orientado pela OMS (2007, p 56) objetiva: "[...] envolver e desenvolver o pensamento crítico e habilidades para a solução de problemas; ser interdisciplinar, multidisciplinar e multidimensional; [...]; incorporar a educação experimental, incluindo a reflexão crítica, a observação e o aprendizado na prática"; preencher a distância entre o meio acadêmico e a prática; desenvolver parcerias e beneficiar os atores envolvidos na saúde. E se complementa com o aprendizado baseado em problemas por meio

da identificação do problema; da exploração do conhecimento preexistente; da geração de hipóteses e mecanismos possíveis; da identificação de questões e objetivos de aprendizado; do autoestudo e do aprendizado em grupo; da reavaliação e da aplicação de novos conhecimentos ao problema; da avaliação e da reflexão sobre o aprendizado (OMS, 2007, p.57).

A evidência, portanto, do uso de novas tecnologias na formação em saúde assinala que as instituições de educação precisam melhorar seu desempenho e podem oferecer contribuições sobre a intensificação de habilidades, capacidades, para adequar o perfil profissional às necessidades da área da saúde. A definição de EPS pela Opas e OMS, a partir do texto organizado por Rovere (1994), compreende a educação no trabalho, pelo trabalho e para o trabalho, nos diferentes serviços cuja finalidade é melhorar a saúde da população .

O texto esclarece ainda que a EPS, atuando sobre o processo de trabalho em saúde, está orientada a atingir a qualidade dos serviços e a própria situação de saúde da população, dentro dos determinantes das características do modelo organizacional e das formas de relacionamento dos serviços com a sociedade. Está, portanto, diretamente relacionada à qualidade do atendimento da atenção, que quando não é satisfatória, transforma-se em um grande problema social. Isso torna evidente que, sendo os serviços de saúde ser- 
viços de pessoas para pessoas, o principal fator de qualidade da atenção está constituído pela disponibilidade, atitude, conhecimento e desempenho dos trabalhadores da saúde (Rovere, 1994).

Nesse sentido, a Opas e a OMS compreendem que a EPS é, da mesma maneira, ferramenta para a investigação e a (auto) análise do trabalho, instrumento de problematização, mecanismo para elaborar conflitos, proposta de busca e incorporação crítica de novas tecnologias e de novos procedimentos, ou seja, novas formas de fazer as coisas, podendo constituir-se em uma das principais estratégias para melhorar a qualidade dos serviços de saúde. Isto não significa que as diversas atividades de formação e capacitação no setor saúde correspondam ao que se caracteriza como educação permanente, uma vez que "[...] os processos educativos neste campo podem ser considerados como intervenções capazes de mobilizar, circular, produzir e transferir conhecimento, tecnologia, valores e sentimentos" (Rovere, 1994, p.25).

Considera-se que o simples fato de colocar os trabalhadores da saúde como sujeitos do processo de aprendizagem provoca o conhecimento, uma vez que tomam a experiência de vida como material para reflexão do processo. Essa necessidade é refletida pelo trabalhador da saúde:

Nós não demos continuidade ou estamos engatinhando. Poderíamos estar bem mais avançados, mas por uma série de questões, de governabilidade, nós paramos. [...] Fizemos discussões (no Conselho de Saúde) pra mostrar que existem esses fóruns de discussões, mas nada assim, de estar levando ou motivando e incentivando a participação e a formação. Foi citado que eles estão fazendo cursos (na prefeitura), como se o sistema de saúde fornecesse condições das pessoas estarem se formando. Eles (chefias) não veem a real necessidade das pessoas, eles trazem alguma coisa que tá já pronta para as pessoas se adequarem, ainda está assim. [...] Não é como sugere a proposta da política. A partir da problematização, ainda não é nesse sentido. [...] É repasse de informação. Não é como uma abordagem, uma reflexão. Não é como uma abordagem para transformação. (S1)

Verificou-se, nas entrevistas, que o desenvolvimento da educação permanente inserida no processo de trabalho na saúde depende do apoio dos gestores ou chefias, conforme relato dos sujeitos, uma vez que essa estratégia envolve a construção de espaços para diálogo e participação dentro dos serviços de saúde, o que leva a pensar que a potencialização da educação 
permanente na locorregião necessita de compromisso e do próprio fortalecimento do Polo do SUS. Ressalta este sujeito:

Por que não conseguiu construir o diálogo? Porque era uma das coisas básicas. Era básico. [...] E frustra, não frustra? Então é, também assim, tudo interrogado. Será que é esse o caminho? Por que a gente é sempre o último a saber? Por que, né? Então, talvez tá interrompendo aí. Porque lá em cima (Ministério da Saúde), será que eles sabem o que tá acontecendo aqui? [...] Porque, no papel vocêescreve o que você quiser. [...] Eu penso assim. Mas começou com quantos (facilitadores)? Foi vinte? E chegou no final com quantos? Nove? Nem a metade. [...] Agora, o que eu vejo, teve regiões que tava muito organizada, que fazem a discussão da educação em saúde há muito tempo, e esse, essas regiões não pararam em razão do Ministério, elas continuaram, entendeu? É porque a nossa região não valoriza isso, essa questão da educação permanente. Então tem esse aspecto, porque independentemente do Ministério, o SUS, ele anda, a gente trabalha, não é? (S4)

A formação profissional, como propõe a Política de EPS, está inserida no processo global de formação do sujeito que trabalha. No entanto, Arroyo (1996, p.7) diz que se pode "observar a opção feita de considerar a área da educação profissional não como uma área pública, sob a responsabilidade do Estado, mas como uma área privada, de responsabilidade do capital”, um fato que tem marcado o Brasil historicamente.

Porém, para responder a essas questões, é necessário, anteriormente, ter claro o direito de qualquer cidadão sujeito a uma formação ampla, uma educação capaz de contribuir para sua inserção crítica e transformadora do mundo em que vive. Não podem ser desconsideradas que as transformações pelas quais passa a humanidade, e que demandam do trabalhador atributos de polivalência, exigem do mesmo modo uma reação diante dos discursos oficiais.

O expresso nas entrelinhas das falas dos sujeitos é que, para o conteúdo da EPS ser aplicado na realidade das unidades de saúde e consolidar o SUS como uma política universal, é preciso que haja integralidade das ações, especialmente na esfera municipal. Da mesma forma, salienta-se que é necessário que haja vontade política, traduzida no engajamento político e em programas de ação tanto dos trabalhadores como dos gestores. E que haja planejamento, incentivo, formas de avaliação na aplicabilidade das ações e a participação dos atores envolvidos. 
Observa-se ainda que a gestão municipal e estadual do SUS na locorregião de Franca não assumiu efetivamente a Política de EPS como uma política criada para mudança de paradigma visando à integralidade da atenção. As ações de Educação Permanente em Saúde foram desenvolvidas reproduzindo o modelo tradicional, e não apontaram a perspectiva de ser permanente, ainda que os trabalhadores da saúde mostrassem interesse e disposição para a formação profissional.

As informações obtidas nas entrevistas permitem afirmar que a implementação da Política de EPS na locorregião de Franca, mesmo com todas as dificuldades relatadas, de maneira geral foi considerada satisfatória pelos sujeitos envolvidos. Contudo, nas questões dirigidas ao desenvolvimento das ações de EPS, não houve o apoio e incentivo necessário, não permitindo construir ações efetivas que pudessem interferir no modelo de atenção à saúde.

Associa-se a esse conjunto de questões a análise de que as diretrizes propostas pela Política de EPS, ao serem efetivadas por meio do Polo do SUS na locorregião de Franca, não foram concretizadas pela ausência de articulação, da participação ativa e do desenvolvimento da autonomia dos atores do SUS. Observa-se, ainda, a grande contribuição dos trabalhadores na reflexão dos processos de trabalho a partir dos problemas vivenciados no cotidiano, das trocas de experiências e dos saberes existentes, o que ressalta a possibilidade concreta de se desenvolver a aprendizagem significativa na saúde.

O ensino-aprendizagem é um processo que se efetiva no campo da educação e, como tal, articula-se à vida das sociedades e das pessoas. Como refere Brandão (1985), a educação é um processo histórico, feito por indivíduos que carregam crenças, valores, aspirações, motivações, propósitos, sentimentos, e é influenciada pelas realidades sociais, sociedades, época e período histórico em que a educação é tomada. Como revelam as falas destes sujeitos:

Penso que é questão da insatisfação, que temos essa insatisfação, e nós temos que estar sempre comentando essa insatisfação, pra gente não adormecer, pra não esfriar, porque é uma oportunidade muito valiosa que não pode morrer. Depende muito disso. E depende de cada um de nós. (S1)

Trabalhar na saúde tem um significado na vida das pessoas. Trabalhar, hoje, na saúde pública é um pouco idealista mesmo, é sustentar um ideal, sabe? Não adianta você ir e falar: eu vou ser só um funcionário, hoje não dá mais. Ou você 
se compromete ou vai sofrer. [...] É um comprometimento com a saúde coletiva, entendeu? Como melhorar mesmo nosso sistema, fortalecer a saúde. (S2)

Precisa organizar o Polo, de construir o diálogo, mostrar nossa capacidade de construir o diálogo. Construir o trabalho intersetorial e a roda. (S4)

Assim, para finalizar, acredita-se que a educação pode transformar a relação de dominação e submissão existente nas relações da saúde na visão pedagógica proposta pela EPS, que favorece a criticidade e a autonomia, e ainda pode provocar atitudes de defesa da saúde e da própria vida.

Segundo Peluso (2001, p.14), “[...] o ser humano somente se liberta da ignorância na medida em que conhece criticamente a realidade em que está inserido. Ser crítico significa estar preparado para descobrir a própria situação como a de alguém que não conhece toda a verdade das coisas”. 


\section{Considerações finaIS}

Espera-se que os produtos obtidos nesta pesquisa possam contribuir para a ampliação do entendimento do SUS e de suas Políticas de implementação. Neste caso, em específico, focou-se na Política Nacional de Educação Permanente em Saúde, entre outras razões, por já estar em andamento, coincidindo com a estratégia do movimento sanitário, na contracorrente do projeto neoliberal adotado pelos governos nacionais.

Desde a década de 1990, em nome da "crise fiscal", transfere-se no País a responsabilidade dos serviços públicos para os indivíduos, deixando intocadas as transformações necessárias da maioria dos determinantes dos problemas de saúde da população. O que a pesquisadora observou foi, aliás, que os determinantes sociais da doença eram objetos de mera constatação, como fatores inerentes-permanentes da sociedade brasileira.

A finalização do estudo e as reflexões realizadas durante o processo levaram a ponderar que os problemas levantados e que deram origem à pesquisa não eram imaginosos e que não se estudou um corpo estranho. O trabalho estava fundamentado na vivência e conhecimento muito próximo, diurnal, de como as ações são desenvolvidas na área da saúde na locorregião de Franca.

Observa-se que, na prática, a trajetória da Política de Educação Permanente em Saúde foi quase que completamente desenvolvida dentro do modelo predominante e tradicional de ensino e que foi implementada mais como cumprimento de funções e tarefas da administração estadual e municipal, frente às instruções emanadas do Ministério da Saúde. Pode-se afirmar ainda que, como gestor federal, o Ministério da Saúde também não possibilitou 
a construção das ações a partir da realidade da locorregião de Franca, seus limites e potencialidades.

Além disso, também não foi disponibilizado o tempo necessário para a compreensão da complexidade da Política indicada, que se utiliza da metodologia da problematização como caminho para a aprendizagem significativa do SUS. Esta abordagem foi recomendada aos Polos do SUS como um caminho efetivo para se garantir que todas as ações, serviços e políticas de saúde direcionadas à formação e desenvolvimento dos trabalhadores da saúde conseguissem atingir seus objetivos, como estratégia para mudança de paradigma. Porém, verificou-se que a falta de acompanhamento da metodologia proposta acabou por deixá-la apenas como sugestão, não ocorrendo sua prática efetiva.

A construção desse conhecimento sobre as ações necessárias e realizadas para a implementação de Política de EPS deu-se por meio de entrevistas com os trabalhadores da saúde, atores do SUS, no desafio de prestar uma contribuição ao aprendizado da saúde proposto, ou, ao menos, explicando por que essa energia não produziu os resultados a que se dirigia.

O conhecimento permitido pela apropriação teórico-analítica do conteúdo das entrevistas e observação participante das ações desenvolvidas foi registrado e selecionado, como também a avaliação reflexiva posterior, baseado no que foi dito e observado em todas as instâncias de saúde da locorregião de Franca, até porque a pesquisadora participou do processo e fez uma avaliação dos fatos atrelada à própria autoavaliação de sua atuação na implementação da Política.

Das falas emerge também a paixão dos próprios trabalhadores da área da saúde por seu trabalho construído no cotidiano dos municípios, seus sentimentos e emoções no atendimento. Outro aspecto relevante é a contribuição dos trabalhadores da saúde, que participaram como sujeitos desta pesquisa e expressaram que se sentiram honrados em poder contribuir com mais essa iniciativa de construção do SUS.

A partir dessa constatação, podem-se perceber os novos significados dos processos democráticos passíveis de serem construídos e compartilhados. Se foi possível sentir vivo esse amor pela causa pública, por que então não emerge daí uma parte da força que irá se somar na implementação efetiva do SUS antes que seja esgotado em si mesmo e desapareça para sempre no valo comum da desesperança e nas privatizações incentivadas pelo neoliberalismo? 
De todos os aspectos observados e das informações obtidas a partir das análises das entrevistas realizadas com os atores participantes do processo iniciado pela Política de EPS - os trabalhadores da saúde - do SUS na locorregião de Franca, emergiram alguns temas dominantes durante o discurso. Pela recorrência e pertinência desses temas, foram considerados eixos centralizadores do pensamento, possíveis na realidade e temporalidade.

A cada eixo, foi repensada a Política de EPS, as diretrizes do movimento sanitário, os determinantes sociais, o embasamento teórico e a análise crítica possível da sociedade atual, no aspecto referente à participação dos atores sociais na implementação do processo, especialmente dos trabalhadores da saúde.

Observou-se que, além das dificuldades de construir critérios para nortear o processo de seleção dos facilitadores de EPS por parte do Conselho Técnico Pedagógico da locorregião de Franca no Polo do Nordeste Paulista, não houve acompanhamento das ações desencadeadas. Gerou-se, assim, uma situação pouco favorecedora ao ensino-aprendizagem crítico, dificultando o conhecimento plural e diversificado que proporcionaria o aparecimento do sujeito de alternativas, criando condições para a manutenção tradicional do monopólio do saber e da informação nas mãos de poucos.

Essa contradição entre uma educação libertadora e as práticas de aprendizagem engessadas e dirigidas é aprofundada na análise de Mézáros (2005), ao explicitar como tudo está impregnado de ideologia e interesse em nossas sociedades. Para o autor, há uma interação social na comunicação das ideologias, sendo que cabe ao sistema de ideias dominantes controlar, efetivamente, as instituições culturais e políticas da sociedade, dificilmente revelada por causa da relação de forças.

Verifica-se, ao contextualizar o processo histórico do SUS, que a Política de Educação Permanente em Saúde é uma necessidade que vem sendo apontada pelos trabalhadores dessa área nas últimas Conferências de Saúde, e implica formação e informação em um processo permanente e participativo. Portanto, a proposta da EPS, condicionada à história do SUS e às peculiaridades da introdução de novos conceitos, passou a permear a área da saúde pública a partir da Reforma Sanitária.

Há de se considerar as relações de poder e o peso da ideologia dominante (Mézáros, 2004) durante o processo de implementação da Política para a busca coletiva de superação das dificuldades que vão surgindo em cada eta- 
pa, como no caso da centralização de decisões nas mãos de poucas pessoas e o desenvolvimento de processos pouco participativos.

Resultam disso algumas posturas de gestores que consideram o interesse de aprimoramento dos trabalhadores como empenho de atualização dos currículos, para ampliar a empregabilidade ou subir em eventual carreira a ser implementada, interesses esses extra-unidade de saúde. Esse pensamento criminaliza o indivíduo na sociedade individualista, culpando-o por querer seu crescimento pessoal-profissional, restringindo o papel libertador da educação à aplicação instrumental a seu campo de prática profissional.

Observa-se que a formação dos facilitadores de EPS no Curso do Ministério da Saúde só se tornou possível graças ao compromisso e à responsabilidade dos trabalhadores envolvidos. Surge aqui, com força, como uma primeira centralidade de análise para a implementação definitiva do SUS, a necessidade da criação de ações e estratégias de longo prazo para a articulação do Polo do SUS, visando à incorporação da participação integrante dos trabalhadores da saúde por meio do alargamento na visibilidade dos critérios de orientação da Política e de sua aplicação prática observada. Portanto, um dos cuidados a serem atendidos seria a identificação em todas as unidades da locorregião, de trabalhadores já envolvidos com práticas educativas, dinâmicas de grupo e processos coletivos, visto que essas ideias orientam a Política de EPS.

Além desses pontos apontados, há também a questão metodológica recomendada para a construção da roda no Polo da locorregião. A princípio, houve o incentivo para o uso da metodologia da problematização, na qual o ensino-aprendizagem ocorre a partir de problemas abstraídos da realidade observada ou estudada.

Essa metodologia, difundida por técnicos coordenadores do Conselho Técnico Pedagógico da locorregião, serviu como instrumento norteador apenas no início do processo, contudo, no decorrer das ações, a problematização não recebeu a ênfase necessária. A falta do acompanhamento pedagógico na condução metodológica das ações de EPS foi um fator que provocou esse distanciamento da proposta da problematização, como se verificou nas análises realizadas sobre a construção da roda na locorregião em relação ao Polo e o Conselho Técnico Pedagógico.

Observa-se, ainda, que a maneira pela qual os facilitadores de EPS foram indicados para a formação e para o desenvolvimento das ações educativas na locorregião provavelmente provocou o desinteresse e serviu de obstáculo ao 
amadurecimento do processo de ensino-aprendizagem crítico. É necessário considerar, no que tange a esse ponto, a possibilidade de que tenha sido reproduzido o que vem sendo vivenciado pelos trabalhadores dos serviços públicos em geral: a falta de estímulo e de incentivo para melhorarem a atuação profissional.

Essa situação de precariedade das condições de trabalho, observada nos serviços públicos em geral, tem-se destacado, tristemente, na área da saúde pela gravidade das consequências, e revelada diariamente na mídia, a qual aponta as situações de atendimento deficitário e escassez de recursos. É, pois, no setor público de saúde que as muitas dificuldades se evidenciam mais claramente, e uma importante razão para isso é a falta de investimento governamental adequado tanto na infraestrutura das instalações físicas quanto no investimento dirigido aos próprios trabalhadores, seja na quantidade, seja na qualidade dos serviços prestados.

Embora a quantidade de funcionários possa ser resolvida até que rapidamente por meio de contratações em concursos públicos, sabe-se que apenas elevar os números não resolve a complexa questão do atendimento integral e humanizado em saúde. É necessário investir em gestão democrática do sistema e na qualidade dos serviços prestados, as quais passam necessariamente pelo crivo da formação profissional e da educação e desenvolvimento dos trabalhadores, que dependem, por sua vez, da continuidade do processo administrativo em linhas permanentes de incentivo, promoção e avaliação de todos os atores envolvidos.

As ações de Educação Permanente em Saúde devem ser desenvolvidas por sujeitos envolvidos e comprometidos com a saúde pública e o SUS. Esse aspecto está explicitado nas falas dos sujeitos. A construção desse processo representa um dos canais para a humanização e para a qualidade do atendimento e pode favorecer não só o entendimento abstrato, mas também a compreensão ativa dos determinantes sociais do processo de adoecimento e nas condições de vida.

Os trabalhadores da saúde têm possibilidade de estabelecer uma nova relação com o usuário dos serviços, a família e a comunidade, consequentemente, com o processo de construção social da saúde. Desse modo, eles podem desencadear ações voltadas para a totalidade, rompendo com o modo fragmentado e descontinuado que, ao longo dos tempos, foi seguido pelas instituições de saúde. 
Essas considerações levaram à necessidade de resgatar a Política de Educação Permanente em Saúde na locorregião de Franca, já que o frágil processo de integração dos atores do SUS demonstra como a formação dos trabalhadores dessa área vem sendo efetivada e seu distanciamento de sua proposta original.

A meta da Política de EPS requer o engajamento dos trabalhadores da saúde em ações que envolvam a comunidade, a equipe de saúde e as práticas multiprofissionais, interdisciplinares, coletivas e intersetoriais. Afasta-se da reprodução das relações tradicionais de poder na sociedade e traz sua proposta fundamentada na mudança de paradigmas. Vem daí a importância da criação dos Polos como espaços democráticos para articular sua implementação, a formação pedagógica e as racionalidades necessárias na implementação definitiva do SUS. Pode-se concluir que a gestão colegiada e a estratégia da EPS conciliam a busca de respostas para problemas vivenciados no cotidiano dos serviços de saúde.

A contribuição da Política de Educação Permanente em Saúde leva a pensar, portanto, uma formação que considere o contexto cultural, educativo, social, econômico e político. E que considere também o conceito ampliado de saúde, transcendendo a dimensão setorial de serviços e o caráter multiprofissional e interdisciplinar dessa produção. Enfim, uma formação que considere a saúde um direito universal, e o SUS, uma política do Estado brasileiro.

A introdução da metodologia de trabalho participativa, como seja, a problematização, traz em si a relação com o que é comum ao grupo e o que vivencia em seu campo de trabalho, substituindo os tradicionais modelos de transmissão do conhecimento. A problematização, ao trazer no primeiro plano a elaboração conjunta dos temas e a construção do novo conhecimento, não evidencia a um sujeito o poder de ensinar e a outro a obrigação de aprender, uma vez que é dinâmica e participativa. Esse processo de ensinar aprendendo, ou aprender ensinando, revira antigas certezas e exige a capacitação dos chamados a ser "professores" no processo.

No contexto do SUS, a problematização foi ressaltada para a construção de relações baseadas em uma prática pedagógica transformadora em que os sujeitos são motivados a experimentar uma maneira diferente de ver o mundo, em uma postura crítica e ativa para a solução de problemas que são comuns e coletivos. Esse caráter fortemente político do trabalho pedagógico a partir da problematização é condição para o desenvolvimento de uma inteli- 
gência da escuta, do cuidado, do tratamento em si, para a produção das aprendizagens relativas à intervenção na vida social e coletiva.

Portanto, para que o trabalhador possa ocupar lugar ativo na saúde, é preciso abandonar, ou desaprender, o sujeito que é submisso e reprodutor de modelos hegemônicos, e ser um sujeito produtor de subjetividade, permitindo-se "aprender a aprender" permanentemente. O desafio, portanto, é pensar uma nova pedagogia na saúde que possa implicar a construção de sujeitos comprometidos sócio-historicamente com a construção da vida e sua defesa, social e coletiva.

Desse modo, problematizar as questões da saúde é tornar a reflexão e a análise uma prática de pensamento no trabalho; é agir ativamente para acolher as incertezas e o estranhamento. Isso deve permitir valorizar as capacidades, desenvolver as potencialidades existentes em cada realidade, estabelecer a aprendizagem significativa, efetiva e crítica.

Eventualmente, utiliza-se dos argumentos da dificuldade e desinteresse dos trabalhadores de campo para trilhar os tortuosos caminhos do pensar abstrato, ao se introduzir o processo de teorização de conteúdos inerentes à prática. Ressalta-se que o trabalho examinado pelo olhar teórico-crítico de revisão de pensar o realizado, e o que se havia proposto a saber e realizar, também pode gerar desconforto e incerteza acerca do que se vive e acredita.

Ao deter essas dificuldades na implementação da Política na locorregião de Franca surge outro problema: a circularidade na indicação e/ou convite dos escolhidos para participar, os quais são sempre os mesmos, "aquele que sempre vai” é novamente o escolhido. Centraliza, então, o conhecimento e as oportunidades de aprendizagem sempre nas mesmas pessoas, o que significa aumento de poder, possibilidade esta já apontada nos estudos de Foucault (1979). Ao mesmo tempo, exclui o princípio da Política de EPS, baseado na integralidade do atendimento, já que a proposta para ser efetiva não pode ficar limitada apenas a um grupo reduzido de pessoas.

A transformação das práticas de saúde, ainda com ênfase curativa e pouco democrática, depende de ações educativas que deem condições para o pensar fazer na saúde, na perspectiva da cidadania, e não da doença. Por outro lado, existem alguns casos, por vezes isolados, de funcionários que são convidados por demonstrarem atitude pró-ativa e colaboração no andamento do trabalho. Esse é o "bom funcionário", que merece retorno por seu desempenho e boas oportunidades. 
Isto porque não existe no serviço público uma maneira de incentivar os "bons" a continuarem "bons" ou melhorarem cada vez mais, havendo uma equalização perversa. Tanto os "bons" funcionários como os considerados "desleixados", os indiferentes e até os que se colocam em posição contrária aos princípios do SUS recebem os mesmos proventos e benefícios, não havendo qualquer diferenciação, o que, afinal, coloca todos no mesmo patamar. A colaboração com o serviço e a preocupação com o próprio aprimoramento passam a ser uma opção individual, embora algumas vezes ressalvadas as questões coletivas determinantes, na disputa de atender-se o mínimo possível de usuários.

Acrescenta-se a essas considerações que a centralização no gerenciamento das ações de EPS introduzida para viabilizá-las em curto espaço de tempo também gerou dificuldades em seu desenvolvimento, afastando igualmente as possibilidades de ampliação da participação decisória de outros atores sociais.

A manutenção do poder de decisão, observada nas ações dos coordenadores, de certa forma tornava verticalizadas as decisões da Política de Educação Permanente em Saúde na locorregião. Nem no Polo do Nordeste Paulista nem nos trabalhos do Conselho Técnico Pedagógico do Núcleo de Franca havia distribuição decisória da programação a ser efetivada, e as propostas circulavam já definidas em algum outro fórum, certamente premidas que eram pela urgência de implementação.

A checagem de informações e do próprio processo decisório era desestimulada pela coordenação do Conselho Técnico Pedagógico pelos seguintes fatores: falta de tempo, pressa e a realização de atividades tardiamente indicadas pelo Ministério da Saúde. Como foi no processo de escolha dos facilitadores de EPS, as rodas de discussão ficaram restritas, e a locorregião não conseguiu construir e ampliar a participação dos atores sociais. Essa urgência foi imposta também verticalmente pelo Ministério da Saúde, reproduzindo o autoritarismo das relações de trabalho aos coordenadores na aceleração da escolha dos facilitadores e inclusive na insuficiência de preparo das próprias pessoas envolvidas com a familiarização da metodologia a ser utilizada.

As dificuldades de entendimento do uso da metodologia da problematização vêm de encontro com a afirmação de que o Polo da locorregião não conseguiu construir o diálogo intersetorial, reproduziu-se o comportamento tradicional e centralizador. Esse fato comprometeu o amadurecimento 
dos atores envolvidos com a avaliação das ações e a possível reformulação do modus operandi processual.

Mais grave ainda, e como consequência da descontinuidade das ações do Poder Central, a própria equipe de trabalho foi desarticulada, e os trabalhos do Polo no Conselho Técnico Pedagógico da locorregião de Franca foram sendo esgarçados até que, finalmente, por falta de apoio, encerrados. Podese sintetizar que, no caso da locorregião de Franca, a implementação da Política Nacional de Educação Permanente em Saúde foi operacionalizada para o cumprimento dos prazos.

Essas conclusões, ao mesmo tempo advindas das entrevistas, bem como da observação participante da pesquisadora por ocasião da implementação da Política, vêm cercadas pela desinformação dos próprios sujeitos entrevistados a respeito dos acontecimentos após o encerramento do Curso de Formação do Ministério da Saúde: a maioria dos entrevistados informa que não recebe nenhuma informação e foi excluída do processo pelo Polo.

Entre os limites observados na implementação desta Política, salienta-se a reprodução do modelo tradicional de formação, ou seja, do processo de aprendizagem, o que se refletiu na falta de participação ativa e crítica de diversos atores no Polo. Isso mostra que a aprendizagem significativa, ao ser introduzida pela problematização, não foi assimilada e compreendida pelos atores envolvidos.

A gestão colegiada do Polo, que se considera inovadora e desafiante, nem sempre possibilitou a superação da dificuldade no reconhecimento da diversidade, das opiniões diferentes, de experimentar mudanças e de incentivar a participação de outros atores sociais. Os problemas de comunicação entre os diversos membros do processo não foram resolvidos nas reuniões do Conselho Técnico Pedagógico do Núcleo de Franca. Constata-se, assim, que o Polo de Educação Permanente em Saúde na locorregião não conseguiu construir a roda para integração e articulação dos atores envolvidos no SUS.

A educação permanente em saúde requer uma postura de reconhecimento do saber do outro, de aceitar o diálogo, o exercício democrático e participativo. Observa-se ainda certa posição autoritária e centralizadora na gestão do SUS na locorregião, e esta não reconhece, não apoia ou incentiva a formação profissional.

Embora o discurso aconteça nesse sentido, na prática não é o que vivenciam tais funcionários públicos. Os gestores, por sua vez, em sua 
maioria entraram no processo, negando-se a ver o papel político e pedagógico de transformação social inserido na proposta. Contrariamente às decisões tomadas no Polo, então possuidor de poder e de verbas, foram políticas e não técnicas, centralizadoras e sem a participação dos trabalhadores da saúde e das necessidades vivenciadas por eles no exercício profissional.

Os trabalhadores da saúde mostram que a construção do SUS precisa estabelecer uma gestão integral da saúde mais solidária e mais coletiva; exige o enfrentamento desses desafios visando à superação das dificuldades de acesso, financiamento, gerenciamento etc. A análise dessa conjuntura mostra que as limitações não se restringem ao setor saúde nem ao município de Franca e locorregião. O Estado brasileiro ainda não está voltado à edificação das reformas sociais necessárias à superação da negatividade dos determinantes sociais na vida da população.

A Reforma Sanitária é um exemplo dessa afirmação, e apesar de ser um dos movimentos sociais mais completos da história do País, continua inconclusiva. A descontinuidade dos processos e as contradições da política do SUS e do Estado sobrepõem-se umas às outras, sem superar as dificuldades estruturais ou mesmo conjunturais para a execução plena das políticas públicas de proteção social.

Isso refletiu na experiência da construção da Política de Educação Permanente em Saúde na locorregião de Franca, que ao ser implementada "de cima para baixo" não constituiu algo inovador na área da saúde, pois faltou desenvolver a prática democrática e participativa. Constata-se, contudo, que essa é a primeira oportunidade em que a educação permanente em saúde se tornou uma política pública, exigindo mudança da mentalidade da "prestação de atendimento com qualidade" para "o direito do usuário à qualidade em saúde".

Houve ainda, como um dos aspectos mais positivos, a introdução da possibilidade de mudança nas ações e práticas profissionais na área da saúde, a partir do diálogo sobre os princípios e diretrizes do SUS, principalmente sobre a integralidade da atenção. Essa visão ampliada tornou plausível aumentar a compreensão do Sistema Único de Saúde e seu funcionamento com estratégias voltadas para todas as categorias profissionais, permitindo o reconhecimento das dezesseis profissões da saúde com a necessidade de formação e educação permanente. 
A busca de respostas e de esclarecimentos que inspiraram a realização desta pesquisa, principalmente a possibilidade de aproveitar as experiências e saberes dos atores sociais envolvidos na saúde, mostram a contribuição deste estudo para o SUS da locorregião. Constatou-se a aprovação generalizada dos trabalhadores da saúde da formação em EPS, que considerou pertinente e que teve um significado tanto profissional como pessoal, indicando que essa iniciativa tivesse continuidade.

Portanto, a implementação da Política de Educação Permanente em Saúde em Franca e na locorregião não passou despercebida, e mesmo sendo resultante de um esforço desarticulado e pouco partilhado, deixou suas marcas nessa área. São os aspectos positivos provocados, e devem ser enfatizadas as modificações introduzidas no cotidiano da atenção à saúde, à aproximação, ainda que um tanto insuficientes, mas pela primeira vez efetivadas, das ações de educação com os serviços de saúde e a gestão do SUS.

Foi possível notar, também, o início da mobilização e integração, mesmo restritas, entre os quatro atores do SUS: a gestão, o trabalhador da saúde, os órgãos formadores e o usuário. Esse entrosamento incipiente permitiu que se realizasse o levantamento dos problemas e de necessidades da realidade local e regional e o estabelecimento de prioridades para a realização das ações de formação, mas cujo desenrolar foi interrompido precocemente pelas mudanças administrativas e políticas.

Destaca-se nas falas dos sujeitos que se tornou evidente a questão do conhecimento acerca da definição do que seja o SUS, seus princípios e diretrizes organizacionais e de seu conceito ampliado de saúde. Nesse sentido, o SUS é referenciado pelos trabalhadores da saúde como uma política pública do Estado brasileiro e um direito universal da população. O que leva a afirmar que a formação permanente contribui de maneira significativa para o trabalho no SUS, seu conhecimento e funcionamento

O trabalhador da saúde, como ser humano, como sujeito histórico social e cultural, sujeito de direitos, tem direito ao saber socialmente construído. A educação permanente destina-se a fortalecer a autonomia dos sujeitos na produção da saúde, capazes de ser criativos no pensar, no sentir, no querer e no atuar.

Não se pode negar que há um reconhecimento internacional da necessidade de mudança na educação dos profissionais da saúde, da qual o aparelho formador é comandado por projetos neoliberais e pelo mercado, e não res- 
ponde as demandas sociais e de saúde. O processo de mudança da educação traz inúmeros desafios, entre os quais o de romper com estruturas e modelos de ensino tradicional para formar profissionais de saúde com competências que lhes permitam recuperar a dimensão essencial do cuidado em saúde.

Resta ainda, para finalizar, dizer como pesquisadora e especialmente como trabalhadora da saúde a emoção em concretizar este trabalho, que traduz em palavras os sonhos e ideais de compromisso e respeito com a vida humana. Vivenciaram-se não só experiências e oportunidades de exercitar os saberes, conhecimentos e limites acerca da saúde e da educação permanente em saúde, mas também, e principalmente, usufruiu-se da oportunidade de provar o grande desafio de construir a roda de aprendizado e de trocas, tornando possível realizar a aliança de emoção e trabalho voltado à coletividade. 


\section{REFERÊNCIAS BIBLIOGRÁFICAS}

ABREU, H. B. de. As novas configurações do estado e da sociedade civil. In: Capacitação em Serviço Social: Crise contemporânea, questão social e Serviço Social. Mod. 1. Brasília, DF: Cead: CFESS: ABEPSS: UnB, 1999.

ALMEIDA, N. L. T. de. Retomando a temática da sistematização da prática em Serviço Social. In: MOTA, A. E. et al. (Orgs.). Serviço Social e saúde: formação e trabalho profissional. São Paulo: Opas: OMS: Ministério da Saúde, 2006.

ANDERSON, P. Balanço do neoliberalismo. In: SADER, E.; GENTILI, P. Pósneoliberalismo: as políticas sociais e o Estado democrático. Rio de Janeiro: Paz e Terra, 1995.

ANDRADE, L. O. M.; BARRETO, I. C. de H. C. Promoção da Saúde. Cidades/ Municípios Saudáveis: propostas de articulação entre saúde e ambiente. In: MINAYO, M. C. de S.; MIRANDA, A. de C. (Orgs.). Saúde e ambiente sustentável: estreitando nós. Rio de Janeiro: Fiocruz, 2002.

ANTUNES, R. Adeus ao trabalho: ensaio sobre as metamorfoses e a centralidade do mundo do trabalho. 6.ed. São Paulo: Cortez; Campinas: Ed. Unicamp, 1999. (Org.). Riqueza e miséria no Brasil. São Paulo: Boitempo, 2006.

ARRETCHE, M. T. S. Políticas sociais no Brasil: descentralização em um Estado federativo. Revista Brasileira de Ciências Sociais, São Paulo, v.14, n.40, p.1319, 1999.

ARROYO, M. G. A atualidade da educação popular. Revista de Educação Pública, Cuiabá, v.11, n.19, p.129-137, jan./jun. 2002.

BARBOSA, L. O jeitinho brasileiro: a arte de ser mais igual que os outros. Rio de Janeiro: Campus, 1992.

BARROS, R.; MENDONÇA, R. Os determinantes da desigualdade no Brasil. Rio de Janeiro: IPEA, 1995.

BEHRING, E. R.; BOSCHETTI, I. Política social: fundamentos e história. São Paulo: Cortez, 2006. (Biblioteca básica de Serviço Social, v.2). 
BELLONI, I. et al. Metodologia de avaliação de políticas públicas: questões de nossa época. São Paulo: Cortez, 2000.

BERBEL, N. A. N. A problematização baseada em problemas: são diferentes termos ou diferentes caminhos? Interface Comunicação, Saúde e Educação, Botucatu, n.2, p.139-154, fev. 1998.

BERTANI, I. et al. Aprendendo a construir saúde: desafios na implantação da política de educação permanente em saúde. Franca: Ed. Unesp/FHDSS, 2008.

BERTUSSI, D. Caminhos para a educação permanente. Brasília, DF: Ministério da Saúde, 2004.

BOFF, C. Que fazer? teoria e prática da educação popular. Petrópolis: Vozes, 1989.

BRASIL. Constituição (1988). Constituição da República Federativa do Brasil. 18.ed. Brasília, DF: Senado, 1988.

Lei 8.080, de 19 de setembro de 1990. Dispõe sobre as condições para a promoção, proteção e recuperação da saúde, a organização e o funcionamento dos serviços correspondentes e dá outras providências. Diário Oficial da União, Brasília, DF, 19 set. 1990a. Seção 1. Disponível em: <http:// portal.saude.gov.br/portal/arquivos/pdf/Lei8142.pdf>. Acesso em: 4 mar. 2004.

Lei 8.142, de 28 de dezembro de 1990. Dispõe sobre a participação da comunidade na gestão do Sistema Único de Saúde (SUS\} e sobre as transferências intergovernamentais de recursos financeiros na área da saúde e dá outras providências. Diário Oficial da União, Brasília, DF, 31 dez. 1990b. Seção 1. Disponível em: <http://portal.saude.gov.br/portal/arquivos/pdf/Lei8142.pdf>. Acesso em: 4 mar. 2004.

Ministério da Saúde. A questão dos recursos humanos nas Conferências Nacionais de Saúde (1941-1992). Cadernos RH Saúde, Brasília, DF, v.1, n.1, p.218, nov. 1993.

Resolução n.196/96 de 10 de outubro de 1996. Aprova as diretrizes e normas regulamentadoras de pesquisas envolvendo seres humanos. Brasília, DF: Ministério da Saúde, Conselho Nacional de Saúde, 1996.

Anuário Estatístico de Saúde do Brasil. Pesquisa de assistência médico-sanitária de São Paulo: relacionada aos recursos humanos da Direção Regional de Saúde VIII. Brasília, DF: Ministério da Saúde, 2002.

. Resolução no 335 de 27 de novembro de 2003. Aprovação da "Política Nacional de Formação e Desenvolvimento para o SUS: caminhos para a educação permanente em saúde" e a estratégia de "Polos ou Rodas de Educação Permanente em Saúde”. Brasília, DF: Ministério da Saúde, 2003a.

Conferência Nacional de Gestão do Trabalho e da Educação na Saúde, 3, 2003, Brasília, DF. Relatório final. Brasília, DF: Ministério da Saúde, 2003 b.

Secretaria de Gestão do Trabalho e da Educação na Saúde. Departamento de Gestão da Educação na Saúde. Caminhos para a mudança da forma- 
ção e desenvolvimento dos profissionais de saúde: diretrizes para a ação política para assegurar Educação Permanente no SUS. Brasília, DF: Ministério da Saúde, 2003c.

Gabinete do Ministro. Institui a Política Nacional de Educação Permanente em Saúde como estratégia do Sistema Único de Saúde para a formação e o desenvolvimento de trabalhadores para o setor e dá outras providências. Portaria no 198/GM - MS, de 13 de fevereiro de 2004. Brasília, DF: Ministério da Saúde, 2004a.

. Conselho Nacional de Saúde. Conferência Nacional de Saúde: conferência Sérgio Arouca, 12, 2003, Brasília. Relatório final. Brasília, DF: Ministério da Saúde, Conselho Nacional de Saúde, 2004b.

Departamento de Apoio à Descentralização. O SUS no seu município: garantindo saúde para todos. Brasília, DF: Ministério da Saúde, 2004c. (Série B. Textos Básicos de Saúde).

História das conferências. Disponível em: <http:// www.fiocruz.gov.br/historia/Conferencias.htm>. Acesso em: 22 abr. 2004d. . Educação permanente entra na roda: polos de educação permanente em saúde - conceitos e caminhos a percorrer. 2.ed. Brasília, DF: Ministério da Saúde, 2005a.

Secretaria de Gestão do Trabalho e da Educação na Saúde. Departamento de Gestão da Educação na Saúde. Curso de formação de facilitadores de educação permanente em saúde: unidade de aprendizagem Trabalho e Relações na Produção do Cuidado. Brasília, DF: SGTES, 2005b.

. Secretaria da Gestão do Trabalho em Saúde. Departamento de Regulação do Trabalho em Saúde. Brasília, DF: Ministério da Saúde, 2005c. Disponível em: <http://portal.saude.gov.br/portal/arquivos/pdf/ apresprogesusdegerts.pdf>. Acesso em: 19 dez. de 2005.

Conselho Nacional de Saúde. Princípios e diretrizes para a gestão do trabalho no SUS (NOB/RH-SUS). 3.ed. Brasília, DF: Ministério da Saúde, 2005d.

Conselho Nacional de Saúde. $3^{\underline{a}}$ Conferência Nacional de Gestão do Trabalho e da Educação na Saúde: trabalhadores de saúde e a saúde de todos os brasileiros: práticas de trabalho, gestão, formação e participação. Base. Brasília, DF: Ministério da Saúde, Conselho Nacional de Saúde, 2005e.

A construção do SUS: história da reforma sanitária e do processo participativo/Vicente de Paula Faleiros. et al. Brasília, DF: Ministério da Saúde, 2006a. (Série I História da saúde no Brasil).

O SUS de A a Z: garantindo saúde nos municípios. 2. ed. Brasília, DF: Ministério da Saúde, 2006b.

Glossário temático de gestão do trabalho e da educação na saúde. Brasília, DF: Ministério da Saúde, 2007a. 
. Gabinete do Ministro. Dispõe sobre as diretrizes para a implementação da Política Nacional de Educação Permanente em Saúde e dá outras providências. Portaria no 1996/GM/MS, de 20 de agosto de 2007. Brasília, DF: Ministério da Saúde, 2007b.

Conselho Nacional de Saúde. 13르 Conferência nacional de saúde: saúde e qualidade de vida, políticas de Estado e desenvolvimento. Relatório Final. Brasília, DF: Ministério da Saúde, 2008. (Série C. Projetos, Programas e Relatórios).

BRAVO, M. I. de S. Serviço social e reforma sanitária: lutas sociais e práticas profissionais. São Paulo: Cortez, 2000.

. Política de saúde no Brasil. In: MOTA, A. E. et al. Serviço Social e Saúde: formação e trabalho profissional. São Paulo: OPAS: OMS: Ministério da Saúde, 2006.

.; MATOS, M. C. de. A saúde no Brasil: reforma sanitária e ofensiva neoliberal. In: BRAVO, M. I. de S. (Org.). Política social e democracia. 2. ed. São Paulo: Cortez, 2002

. Reforma Sanitária e projeto ético-político do Serviço Social: elementos para o debate. In: BRAVO, M. I. de S. et al. Saúde e Serviço Social. São Paulo: Cortez; Rio de Janeiro: Ed. UERJ, 2004.

; MENEZES, J. S. B. de. Política de saúde no Rio de Janeiro: algumas reflexões a partir dos anos 1980. In: BRAVO, M. I. S. et al. Política de saúde na atual conjuntura: modelos de gestão e agenda para a saúde. Rio de Janeiro: Ed. UERJ: Rede Sirius, 2007.

CAMPOS, F. E. de. A desprecarização é urgente. Radis - Comunicação em Saúde, Rio de Janeiro, n.46, p.8-10, jun. 2006.

CAMPOS, G. W. de S. Reforma da reforma: repensando a saúde. 2.ed. São Paulo: Hucitec, 1997.

Um método para análise e co-gestão de coletivos: a constituição de sujeito, a produção de valor de uso e a democracia em instituições: o método da roda. São Paulo: Hucitec, 2000.

. Os desafios atuais para a educação permanente no SUS. Caderno RH Saúde, Brasília, DF, v.3, n.1, p.41-51, 2006a.

Reflexões sobre a construção do Sistema Único de Saúde (SUS): um modo singular de produzir política pública. Serviço Social E Sociedade, São Paulo, ano 26, n.87, p.132-146, 2006b.

. Saúde Paideia. São Paulo: Hucitec, 2007a.

Reforma política e sanitária: a sustentabilidade do SUS em questão? Ciência e Saúde Coletiva, Rio de Janeiro, v.12, n.2, p.301-306, mar./abr. 2007b.

CASTELLANOS, P. L. Epidemiologia, saúde pública, situação de vida e condições de vida. Considerações conceituais. In: BARATA, R. B. (Org.). Condições de vida e situação de saúde. Rio de Janeiro. Abraso, 1997. 
CARVALHO, A. I. de. Conselhos de saúde no Brasil: participação cidadã e controle social. Rio de Janeiro: Fase: Ibam, 1995.

CECCIM, R. B. Educação permanente em saúde: desafio ambicioso e necessário. Interface-Comunicação, Saúde, Educação, Botucatu, v.9, n.16, p.61-177, 2005a.

Educação permanente em saúde: descentralização e disseminação de capacidade pedagógica na saúde. Ciência e Saúde Coletiva, Rio de Janeiro, v.10, n.4, p.975-86, 2005b.

.; FEUERWERKER, L. C. M. O quadrilátero da formação para a área da saúde: ensino, gestão, atenção e controle social. Physis: Revista de Saúde Coletiva, Rio de Janeiro, v.14, n.1, p.41-65, 2004.

CFESS. Resolução de no 383, de 29 de março de 1999. Atribuições do assistente social na saúde. Brasília, DF: 1999.

CHAUÍ, M. Escritos sobre a universidade. São Paulo: Ed. Unesp , 2001.

A universidade pública sob nova perspectiva. Revista Brasileira de Educação, Rio de Janeiro, 2003, n.24, sept./dec. 2003. Disponível em: <http:// w w w. s c i e l o.b r / s c i e l o.ph p ? p i d = S 1413 $4782003000300002 \&$ script=sci_arttext\&tlng=pt>. Acesso em: 28 jul. 2008.

COELHO, I. B. O impasse do SUS. Ciência e Saúde Coletiva, Rio de Janeiro, v.12, p.309-311, mar./abr. 2007.

COHN, A. Mudanças econômicas e políticas de saúde no Brasil. In: LAURELL, A. C. (Org.); revisão técnica de COHN, A.; tradução de CONTRERA, R. L. Estado e políticas sociais no neoliberalismo. 2.ed. São Paulo: Cortez, 1997.

Políticas sociais e pobreza no Brasil. Planejamento e Políticas Públicas, São Paulo, n.12, p.1-17, jun./dez, 1995.

COHN, A. Saúde no Brasil: políticas e organização de serviços. São Paulo: Cortez, 1991.

CORTEZ, S. M. V. Balanço de experiências de controle social, para além dos conselhos e conferências no Sistema Único de Saúde brasileiro: construindo a possibilidade da participação dos usuários. Conferência Nacional de Saúde, 11, 2003, Brasília, DF. Reforma do Estado e o setor saúde: a experiência brasileira e a última década. Cadernos. Brasília, DF: Ministério da Saúde, 2003, p.23-42, mimeo.

COSTA, M. M. da (Org.) Educação permanente. Brasília, DF: Ministério da Saúde, 2000. cad. 3.

COUTINHO, C. N. Intervenções: o marxismo na batalha das ideias. São Paulo: Cortez, 2006.

CYRINO, E. G.; TORALLES-PEREIRA, M. L. Trabalhando com estratégias de ensino-aprendizagem por descoberta na área da saúde: a problematização e a aprendizagem baseada em problemas. Cadernos de Saúde Pública, Rio de Janeiro, v.20, n.3, p.780-788, maio/jun. 2004.

DANTAS, P. O bairro dos Coelhos em Recife (PE). Saúde e educação popular. Rio de Janeiro, n.7, p.34-40, 1984. (Cadernos de educação popular, 7). 
DELUIZ, N. Qualificação, competências e certificação: visão do mundo do trabalho. Formação, Brasília, DF, n.2, p.5-15, maio 2001. Disponível em: <http:// www.bra.ops-oms.org/rh/areas_det.cfm?id_doc=119\&id_area=2>. Acesso em: 29 abr. 2006.

DEMO, P. Introdução à metodologia da ciência. São Paulo: Atlas, 1985.

. Metodologia científica em ciências sociais. 2.ed. São Paulo: Atlas, 1989.

Educação e qualidade. São Paulo: Papirus, 1994.

. Combate à pobreza: desenvolvimento como oportunidade. Campinas: Autores Associados, 1996.

. Educação profissional: desafio da competência humana para trabalhar. Educação profissional: o debate da(s) competência(s). Brasília, DF: Ministério do Trabalho, Sefor, 1997.

. Saber pensar. 4.ed. São Paulo: Cortez, Instituto Paulo Freire, 2005.

DOMINGUEZ, B. C. 3a Conferência Nacional de Gestão do Trabalho e da Educação na Saúde: a desprecarização é urgente. Radis - Comunicação em Saúde, Rio de Janeiro, n.46, p.8-11, jun. 2006.

DOWBOR, L. O que é poder local? São Paulo: Brasiliense,1994.

Da globalização ao poder local: a nova hierarquia dos espaços. São Paulo: Brasiliense, 1995.

A reprodução social: propostas para uma gestão descentralizada. Petrópolis: Vozes, 1998.

FALEIROS, V. de P. O trabalho da política: saúde e segurança dos trabalhadores. São Paulo: Cortez, 1992.

Natureza e desenvolvimento das políticas sociais no Brasil. In: Capacitação em serviço social e política social: política social. Mod. 3. Brasília, DF: Cead: CFESS: ABEPSS: UnB, 2000.

FINKELMAN, J. (Org.). Caminhos da saúde pública no Brasil. Rio de Janeiro: Ed. Fiocruz, 2002. Disponível em: <http://www.fiocruz.br/editora/media/04CSPB00>. Acesso em: 2 mar. 2005.

FLEURY, S. 9ª Conferência Nacional de Saúde: uma análise de riscos. Tempo e Presença, v.13, n.260, p.12-13, nov./dez. 1991.

. (Org). A questão democrática na saúde. Saúde e democracia: a luta do Cebes. São Paulo: Lemos, 1997.

FOUCAULT, M. Microfísica do poder. Rio de Janeiro: Graal, 1979.

FRANCO, A. A. de P. A família acolhedora na comarca de Franca: análise crítica do processo de implantação. 2004. 238 f. Tese (Doutorado em Serviço Social) - Faculdade de História, Direito e Serviço Social, Universidade Estadual Paulista Júlio de Mesquita Filho, Franca, 2004.

FREIRE, P. Ação cultural para a liberdade: extensão ou comunicação? Rio de Janeiro: Paz e Terra, 1971. . Pedagogia do oprimido. Rio de Janeiro: Paz e Terra, 1978. 
Educação e mudança. Rio de Janeiro: Paz e Terra, 2001.

Pedagogia da autonomia: saberes necessários à prática educativa. São Paulo: Paz e Terra, 2006.

FRIGOTTO, G. Educação e crise no capitalismo real. São Paulo: Cortez, 1995.

GARCIA, R. C. Juan César García entrevista Ruan César García. In: NUNES, E. GARCÍA, J. C.(Orgs.). As ciências sociais em saúde na América Latina: tendências e perspectivas. Brasília, DF: OPAS, 1985.

GHON, M. da G. Conselhos gestores e participação sociopolítica. São Paulo, Cortez, 2003.

GRAMSCI, A. Os intelectuais e a organização da cultura. Rio de Janeiro: Civilização Brasileira, 1989.

HADDAD, Q. et al. Educación permanente de personal de salud. Washington: OPAS, 1994. Disponível em: <http://www.paho.org/Spanish/HSP/HSR/gestionestrat-capiii.pdf>. Acesso em: 4 abr. 2008.

HELLER, Agnes. O cotidiano e a história. São Paulo: Paz e Terra, 2004.

HOCHMAN, G.; IAMAMOTO, M. V. Renovação e conservadorismo no serviço social. 7.ed. São Paulo: Cortez, 2004.

O Serviço Social na contemporaneidade: trabalho e formação profissional. 8.ed. São Paulo: Cortez, 2005.

As dimensões ético-políticas e teórico-metodológicas no serviço social contemporâneo. In: MOTA, A. E. et al. Serviço Social e Saúde: formação e trabalho profissional. São Paulo: OPAS, OMS, Ministério da Saúde, 2006.

.; CARVALHO, R. de. Relações sociais e serviço social no Brasil: esboço de uma interpretação histórico-metodológica. 5.ed. São Paulo: Cortez, 1986.

IBGE.IBGE - cidades@. Disponível em: <http://www.ibge.gov.br/cidadesat/ default.php>. Acesso em: 10 jun. 2005.

KOSIK, K. Dialética do concreto. São Paulo: Paz e Terra, 2002.

KOWARICK, L. Processo de desenvolvimento do Estado na América Latina e políticas sociais. Serviço Social E Sociedade, São Paulo, ano 6, n.17, p.5-14, abr. 1985.

LAURELL, A. C. Saúde e trabalho: os enfoques teóricos. In: NUNES, E. D. As ciências sociais na América Latina: tendências e perspectivas. Brasília, DF: OPAS, 1989.

Avançando em direção ao passado: a política social do neoliberalismo. In: (Org.); revisão técnica de COHN, A.; tradução de CONTRERA, R. L. Estado e políticas sociais no neoliberalismo. 2.ed. São Paulo: Cortez, 1997.

LIMA, I. B. de. Neoliberalismo, mundo do trabalho e formação docente: a política do Banco Mundial. Políticas Públicas e Sociedade, Fortaleza, ano 3, n.5, p.1725, jan./jun. 2003.

LOURENÇO, E. A. de S. Saúde pública e participação cidadã: uma análise do controle social no SUS em Franca/SP. 2004. 165 f. Dissertação (Mestrado em Ser- 
viço Social) - Faculdade de História, Direito e Serviço Social da Unesp - Universidade Estadual Paulista Júlio de Mesquita Filho, Franca, 2004

; BERTANI, I. F. Uma breve discussão da política social e o campo saúde do trabalhador. In: ENGLER, H. B. R.; SILVEIRA, U. (Orgs.). 30 anos de Serviço Social. Franca: Ed. Unesp , 2006

; _ـ Saúde do trabalhador no SUS: desafios e perspectivas frente à precarização do trabalho. Revista Brasileira de Saúde Ocupacional, São Paulo, v.32, n.115, p.121-134, 2007. Disponível em: <http:// w w w. fundacentro.gov.br/rbso/Banco A n exos/ RBSO\%20115\%20Saúde\%20do\%20trabalhador\%20no\%20SUS.pdf>. Acesso em: 12 fev. 2008.

LUKÁCS, G. História e consciência de classe: estudos de dialética marxista. 2.ed. Rio de Janeiro: Elfos, 1989.

MACHADO, M. H. Trabalhadores de saúde e sua trajetória na reforma sanitária. Cadernos RH Saúde, Brasília, DF, v.3, n.1, p.32-43, mar. 2006.

MARSIGLIA, R. M. G. Orientações básicas para a pesquisa. In: MOTA, A. E. et al. (Orgs.). Serviço Social e saúde: formação e trabalho profissional. São Paulo: OPAS, OMS, Ministério da Saúde, 2006.

MANFREDI, S. M. Política e educação popular. São Paulo: Símbolo, 1978. (Ensaio e memória, n.6).

MARTINELLI, M. L. Serviço social: identidade e alienação. 6.ed. São Paulo: Cortez, 2000.

MARX, K. O capital: crítica da economia política. 23.ed. Rio de Janeiro: Civilização Brasileira, 2006. livro 1.

; ENGELS, F. A ideologia alemã. São Paulo, HUCITEC, 1987.

MASSAKO, I. Cem anos de saúde pública: a cidadania negada. São Paulo: Ed. Unesp, 1994.

MENDES, E. V. Um novo paradigma sanitário. In: Uma agenda para a saúde. São Paulo: Hucitec, 1996.

MERHY, E. E. O desafio que a educação permanente tem em si: a pedagogia da implicação. Interface Comunicação, Saúde, Educação, Botucatu, v.9, n.16, p.172174, abr. 2005.

; ONOCKO, R. (Orgs.). Agir em saúde: um desafio para o público. São Paulo: Hucitec, 1997.

; FEUERWEKER, L. C. M.; CECCIM, R. B. Educación permanente en salud - uma estrategia para intervenir en la micropolítica del trabajo en salud. Salud Colect, La Plata, v.2, n.2, p.147-160, 2006.

MÉSZÁROS, I. O poder da ideologia. São Paulo: Boitempo, 2004. . A educação para além do capital. São Paulo: Boitempo, 2005.

MINAYO, M. C. de S. Pesquisa social: teoria, método e criatividade. 17.ed. Rio de Janeiro: Vozes, 2000. 
O desafio do conhecimento: pesquisa qualitativa em saúde. 8.ed. São Paulo: Hucitec, 2004.

; DESLANDES, S. F. (Orgs.). Caminhos do pensamento: epistemologia e método. Rio de Janeiro: Editora Fiocruz, 2002. (Criança mulher e saúde).

MOREIRA, A. M. Aprendizagem significativa crítica. Disponível em: <http:// www.if.ufrgs.br/ moreira/apsigcritport.pdf >. Acesso em: 3 mar. 2007.

MOTA, A.E. et al. (Orgs.). Serviço social e saúde: formação e trabalho profissional. São Paulo: OPAS: OMS: Ministério da Saúde, 2006.

NETTO, J. P. Repensando o balanço do neoliberalismo. In: SADER, E.; GENTILI, P. Pós-neoliberalismo: as políticas sociais e o estado democrático. Rio de Janeiro: Paz e Terra, 1995.

A construção do projeto ético-político. In: Capacitação em Serviço Social e Política Social: crise contemporânea, questão social e Serviço Social. Mod. 1. Brasília, DF: Cead: CFESS: ABEPSS: UnB, 1999.

Ditadura e serviço social: uma análise do serviço social no Brasil pós-64. 8.ed. São Paulo: Cortez, 2005.

NUNES, E. et al. A saúde como direito e como serviço. 3.ed. São Paulo: Cortez, 2002.

NUNES, E. D. Tendências e perspectivas das pesquisas em ciências sociais em saúde na América Latina: uma visão geral. In: ___ _; GARCÍA, J. C. (Org.). As ciências sociais em saúde na América Latina: tendências e perspectivas. Brasília, DF: Opas, 1985.

OFFE, C. Algumas contradições do Estado social moderno. Trabalho e Sociedade, Rio de Janeiro, v.2, n.1, p.12-21, set.1991.

OMS. Conferência Internacional sobre Cuidados Primários de Saúde: Declaração de Alma-Ata, 1978. Brasília, DF: Ministério da Saúde, 2004.

Relatório mundial de saúde, 2006: trabalhando juntos pela saúde. Brasília, DF: Ministério da Saúde, OMS, 2007. Disponível em: <http:// www.opas.org.br/mostrantp.cfm? codigodest=586>. Acesso em: 4 mar. 2007.

OLIVEIRA, F. Neoliberalismo à brasileira. In: SADER, E.; GENTILI, P. Pósneoliberalismo: as políticas sociais e o estado democrático. Rio de Janeiro: Paz e Terra, 1995.

OLIVEIRA, M. do S. Educação permanente em saúde: o desafio de propor ações articuladas e com capacidade de transformação. Brasília, DF: Ministério da Saúde, 2004.

PAIM, J. S. Bases conceituais da reforma sanitária brasileira. In: FLEURY S. (Org.). Saúde e democracia: a luta do Cebes . São Paulo: Lemos, 1997.

PAIVA, C. H. A. et al. A cooperação técnica Opas -Brasil na formação de trabalhadores para a saúde (1973-1983). Ciência e Saúde Coletiva, Rio de Janeiro, v.13, n.3, dez. 2008. Disponível em: <http://www.scielo.br/ scielo.php? script $=$ sci_arttext\&pid $=$ S1413-81232008000300015\&lng $=$ pt\&nrm=iso $>$. Acesso em: 12 mar. 2007. 
PELUSO, T. C. L. A educação de adultos: refletindo sobre a natureza de sua complexidade. Formação, Brasília, DF, v.1, n.3, p.5-15, mar. 2000.

PEREIRA. P. A. P. Necessidades humanas: subsídios à crítica dos mínimos sociais. São Paulo: Cortez, 2000.

Cidadania e (in)justiça social: embates teóricos e possibilidades atuais. In: FREIRE, L. M. B. et al. Serviço social, política social e trabalho: desafios e perspectivas para o século XXI. São Paulo: Cortez; Rio de Janeiro: Ed. UERJ, 2006. POCHMANN, M. Desempregados do Brasil. In: ANTUNES, R. (Org.). Riqueza e miséria no Brasil. São Paulo: Boitempo, 2006.

PREFEITURA MUNICIPAL DE FRANCA. Secretaria Municipal de Saúde. Plano Municipal de Saúde de Franca. Franca: 2002.

PROJETO ético-político e a vulgarização da forma profissional. Jornal do CRESS SP, São Paulo, jul./set. 2008.

QUEIROZ, D. T. et al. Integralidade, formação de saúde, educação em saúde e as propostas do SUS - uma revisão conceitual. Ciência e Saúde Coletiva, Rio de Janeiro, v.12, n.2, p.335-342, mar./abr. 2007.

ROVERE, M. R. Gestion estrategica de la educacion permanente en salud. In: HADDAD, J. et al. Educación permanente de personal de salud. Organización Panamericana de la Salud. Organización Mundial de la Salud. 1994. Disponível em: <http://www.opas.org.br/mostrantp.cfm? codigodest=586>. Acesso em: 12 mar. 2007.

SADER, E. A hegemonia neoliberal na América Latina. In: SADER, E.; GENTILI, P. Pós-neoliberalismo: as políticas sociais e o Estado democrático. Rio de Janeiro: Paz e Terra, p.35-38, 1995.

Quando novos personagens entram em cena: experiências, fala e luta dos trabalhadores da grande São Paulo, 1970-80. Rio de Janeiro: Paz e Terra, 1998.

SANTANA, J. P. de. História, saúde e seus trabalhadores: o contexto internacional e a construção da agenda brasileira. Ciência e Saúde Coletiva, Rio de Janeiro, v.13, n.3,2008. Disponível em: <http://www.scielo.br/ s c i e lo.ph p ? s cript = s ci_art text \& pid = S 1413 $81232008000300004 \& \operatorname{lng}=$ pt\&nrm=iso $>$. Acesso em: 12 ag. 2008.

SANTOS, B. Ciência. In: CARILHO, M. M. (Dir.). Dicionário do pensamento contemporâneo. Lisboa: Publicações Dom Quixote, 1991.

SANTOS, N. R. dos. Encruzilhada nos rumos do SUS: considerações. 2008.

SANTOS, W. G. dos. Cidadania e justiça: a política social na ordem brasileira. Rio de Janeiro: Campus, 1987.

Razões da desordem. Rio de Janeiro: Rocco, 1994.

SÃO PAULO (ESTADO). Decreto no 51.433, de 28 de dezembro de 2006. Cria unidade na Coordenadoria de Regiões de Saúde, da Secretaria da Saúde, altera a denominação e dispõe sobre a reorganização das Direções Regionais de Saúde e dá providências correlatas. Diário Oficial do Estado de São Paulo, São Paulo, 
n.246, p.1, 29 dez. 2006. Disponível em: <ftp://ftp.saude.sp.gov.br/ftpsessp/ bibliote/informe_eletronico/2006/iels.dezembro.06/iels247/E_DC51433_281206.pdf>. Acesso em: 4 mar. 2007.

SARRETA, F. de S. O trabalho do assistente social na saúde pública. Ciência et Praxis, Passos, v.1, n.1, 2008, p.33-40, dez. 2008.

.; BERTANI, I. F. O polo de educação permanente em saúde e a construção de estratégias coletivas para a formação dos trabalhadores no SUS. Serviço Social e Realidade, Franca, v.14, n.2, p.177-195, 2005.

; _ A construção do trabalho em equipe do Serviço Social no SUS de Franca / SP. In: OLIVEIRA, C. A. H. S.; BERTANI, I. F. Interdisciplinaridade: integração entre saberes e práticas. Franca: Ed. Unesp, 2006.

.; ETO, F. Educação em saúde: construindo experiências na formação e na prática profissional. In: BERTANI, I. F.; REZENDE, R. M. (Orgs.). Conversas interessantes sobre saúde: Programa de Extensão Quavisss. Franca: Ed. Unesp, 2007.

SEABRA, G. de F. Pesquisa científica: o método em questão. Brasília, DF: UnB, 2001.

SEADE. Fundação Sistema Estadual de Análise de Dados. Perfil municipal de Franca. 2007. Disponível em: <http://www.seade.gov.br/produtos/perfil/ perfil.php>. Acesso em: 30 abr. 2007.

SILVA, A. A. da. A gestão da seguridade social brasileira: entre a política pública e o mercado. São Paulo: Cortez, 2004.

SILVA, E. et al. As políticas públicas de saúde no Brasil: o Sistema Único de Saúde (SUS) e a rede de saúde em Franca/SP. Serviço Social e Realidade, Franca, v.16, n.1, p.87-110.

STARFIELD, B. Atenção primaria: equilíbrio entre necessidades de saúde, serviços e tecnologia. Brasília, Df: Unesco : Ministério da Saúde, 2002.

TEIXEIRA, E. O local e o global: limites da participação cidadã. São Paulo: Cortez, 2002.

TEIXEIRA, S. F. Reflexões teóricas sobre democracia e reforma sanitária. In: Reforma sanitária: em busca de uma teoria. São Paulo: Cortez; Rio de Janeiro: Abrasco, 1989.

TEMPORÃO, J. G. Discurso de posse no cargo de Ministro da Saúde em 19 de março de 2007. Informativo da Associação Brasileira de Pós-graduação em Saúde Coletiva, Rio de Janeiro, ano 24, n.98, p.6-10, abr. 2007.

TORREZ, M. N. F. B. Humanizar cuidados de saúde: uma questão de competência. Formação, Brasília, v.1, n.2, p.45-51, 2001.

TRIVIÑOS, A. N. F. Introdução à pesquisa em ciências sociais. A pesquisa qualitativa em educação. São Paulo: Atlas, 1987.

VASCONCELOS, A. M. de. A prática do serviço social: cotidiano, formação e alternativas na área da saúde. São Paulo: Cortez, 2002. 
VASCONCELOS, E. Educação popular nos serviços de saúde. 3.ed. São Paulo: Hucitec, 1997.

VIANA, S. M. et al. Medindo as desigualdades em saúde no Brasil: uma proposta de monitoramento. Brasília, DF: Organização Pan-Americana da Saúde: Instituto de Pesquisa Econômica Aplicada, 2001.

WENDHAUSEN, A.; CAPONI, S. O diálogo e a participação em um conselho de saúde em Santa Catarina. Cadernos de Saúde Pública, Rio de Janeiro, v.18, n.6, p.1.621-1.628, nov./dez. 2002. 


\section{Anexos}

\section{Apêndice A - Roteiro para entrevista}

1. Você pode falar sobre o seu trabalho na área da saúde pública.

A profissão, formação, local de trabalho, atividades que desenvolve.

2. Expresse os sentimentos em relação ao seu trabalho.

3. Aponte o conceito de saúde que inspira o seu trabalho.

4. Expresse suas ideias sobre o Sistema Único de Saúde (SUS). Avalie funcionamento do SUS hoje.

Aponte o que pode ser diferente.

5. Avalie a implantação da Política de Educação Permanente em Saúde O significado para sua formação pessoal e profissional. E para o seu trabalho.

6. Desenvolve experiências de educação permanente em saúde. Consegue vivenciar a metodologia da problematização. Como a educação em saúde pode ser potencializada?

Gostaria de acrescentar alguma coisa, ou tem alguma observação. 


\section{Apêndice B - Termo de consentimento livre e esclarecido}

Você está sendo convidado(a) a participar da pesquisa sobre "A educação permanente em saúde como estratégia para a formação dos trabalhadores do SUS”, desenvolvida no Programa de Pós-Graduação em Serviço Social da Unesp, campus de Franca, nível doutorado. O objetivo é conhecer, analisar e explicar experiências que potencializam a educação permanente em saúde como estratégia para a formação dos trabalhadores da saúde e consolidação dos sistemas públicos de saúde na locorregião de Franca/SP. Para isso, preciso conhecer seus pensamentos e sentimentos sobre o assunto, como trabalhador da saúde pública, com liberdade para manifestar o que julga importante. Para realizar tais propósitos, a entrevista será registrada em gravador com sua autorização, o que possibilitará melhor interpretação do nosso diálogo, assegurando a fidedignidade das informações e enriquecendo a coleta dos dados. Sua participação neste estudo é voluntária. Se você aceitar o convite, poderá mudar de ideia a qualquer momento e interromper sua participação no estudo, sem qualquer problema. A única vantagem proporcionada pela sua participação neste estudo é a contribuição que prestará aos processos de análise relacionados ao Sistema Único de Saúde e da Política Nacional de Educação Permanente em Saúde, o que é, em si, um exercício de cidadania. Sua identidade não será divulgada, será mantido sigilo absoluto.

\section{Consentimento pós-esclarecido:}

Declaro que fui convenientemente esclarecido sobre a pesquisa, que entendi as informações que me foram transmitidas e concordo em participar deste estudo.

Local e data:

Nome do entrevistado:

Nome do pesquisador:

Pesquisadora responsável: Fernanda de Oliveira Sarreta, aluna do Programa de Pós-Graduação em Serviço social da Unesp, campus de Franca. Orientadora: Prof ${ }^{-}$Dra ${ }^{a}$ Iris Fenner Bertani. Professora do Programa de PósGraduação em Serviço Social da Unesp, campus de Franca. 
SOBRE O LIVRO

Formato: $16 \times 23 \mathrm{~cm}$

Mancha: 27,7 $\times 44,9$ paicas

Tipologia: Horley Old Style 10,5/14

1a edição: 2009

\section{EQUIPE DE REALIZAÇÃO}

Coordenação Geral

Marcos Keith Takahashi 

CULTURA
ACADEMICA,
CANA 